\title{
Analysis of Accident Sequences and Source Terms at Waste Treatment and Storage Facilities for Waste Generated by U.S. Department of Energy Waste Management Operations
}

\section{Volume 3: Appendixes C-H}

by C. Mueller, B. Nabelssi, J. Roglans-Ribas, S. Folga, A. Policastro, W. Freeman,* R. Jackson, ${ }^{*}$ S. Turner, ${ }^{*}$ and J. Mishima ${ }^{*}$

Environmental Assessment Division, Argonne National Laboratory, 9700 South Cass Avenue, Argonne, Illinois 60439

April 1995

Work sponsored by United States Department of Energy, Assistant Secretary for Environmental Management

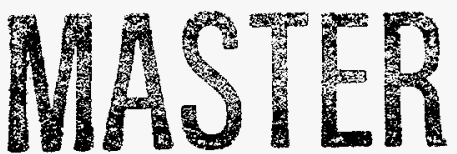

\footnotetext{
* Freeman is affiliated with the University of Illinois at Chicago; Jackson and Turner with Science Applications International Corporation, Golden, Colorado; and Mishima with Science Applications International Corporation, Richland, Washington.
} 


\section{DISCLAIMER}

Portions of this document may be illegible in electronic image products. Images are produced from the best available original document. 


\section{CONTENTS}

\section{VOLUME 1}

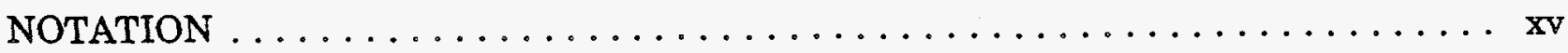

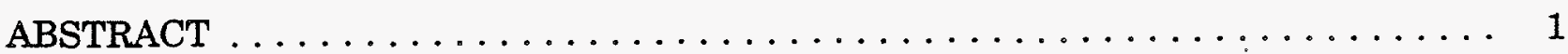

1 INTRODUCTION AND OVERVIEW $\ldots \ldots \ldots \ldots \ldots \ldots \ldots \ldots \ldots \ldots \ldots$

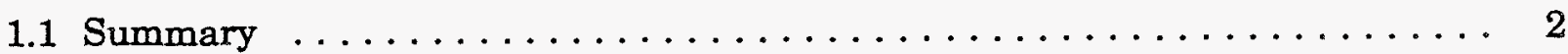

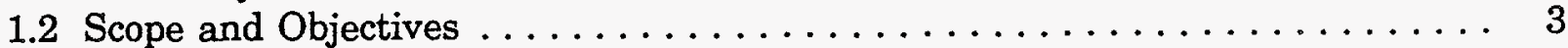

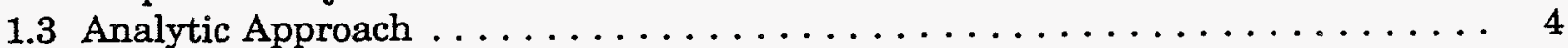

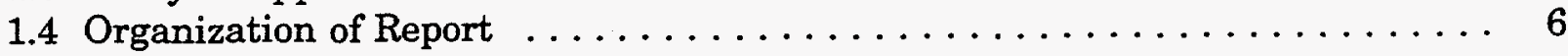

2 METHODOLOGY AND COMPUTATIONAL FRAMEWORK

FOR ACCIDENT ANALYSIS $\ldots \ldots \ldots \ldots \ldots \ldots \ldots \ldots \ldots \ldots$

2.1 Overview . . . . . . . . . . . . . . . . . . . . . . 8

2.2 Selection of Risk-Dominant Operations, Facilities, and Related

Types of Accidents . . . . . . . . . . . . . . . . . . . . . 8

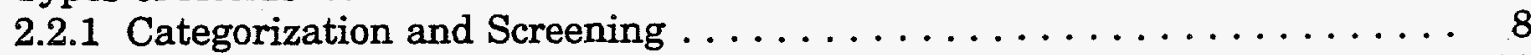

2.2.2 General Handling Accidents $\ldots \ldots \ldots \ldots \ldots \ldots \ldots \ldots \ldots \ldots \ldots \ldots \ldots \ldots$

2.2.3 Storage Facility Accidents . . . . . . . . . . . . . . . . . 11

2.2.4 Accidents Involving Treatment Processes and Facilities . . . . . . . . 12

2.3 Development of Risk-Dominant Accident Sequences . . . . . . . . . 15

2.3.1 Selection and Categorization of Accident Initiators . . . . . . . . . . . 15

2.3.2 Specification and Evaluation of Accident Sequences . . . . . . . . . 19

2.3 .3 Nuclear Criticality . . . . . . . . . . . . . . . . . . . . 22

2.4 Development of Source Terms for Accident Sequences . . . . . . . . . . . 23

2.4.1 Radiological Source Terms . . . . . . . . . . . . . . . . 23

2.4.2 Chemically Hazardous Source Terms . . . . . . . . . . . . . 26

2.5 General Facility Modeling and Inventory Assumptions . . . . . . . . . 27

2.5.1 DOE Design and Performance Criteria . . . . . . . . . . . . 27

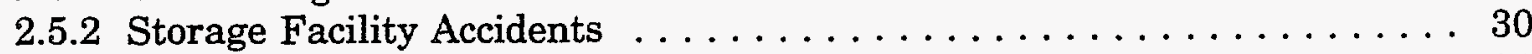

2.5.3 Treatment Facility Accidents . . . . . . . . . . . . . . . 31

2.6 Evaluation of Source Term Parameters and Frequencies . . . . . . . . . 35

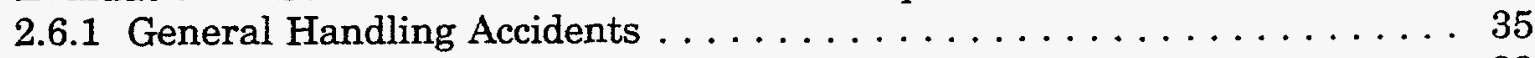

2.6 .2 Storage or Staging Area Accidents . . . . . . . . . . . . . 39

2.6.3 Treatment Facility Accidents . . . . . . . . . . . . . . . 43

2.6 .4 Summary of Data Used . . . . . . . . . . . . . . . . . . 47

2.7 Selection and Calculation of Final Source Terms $\ldots \ldots \ldots \ldots \ldots \ldots$

2.8 Uncertainty in Facility Accident Analysis . . . . . . . . . . . . . 50

3 ACCIDENT ANALYSIS FOR HIGH-LEVEL WASTE . . . . . . . . . 53

3.1 Overview of High-Level Waste Management $\ldots \ldots \ldots \ldots \ldots \ldots \ldots$

3.2 Risk-Dominant Accidents and Modeling Assumptions . . . . . . . . . 56 


\section{CONTENTS (Cont.)}

3.2 .1 Selection of Accidents . . . . . . . . . . . . . . . . . 56

3.2 .2 Sourcé Term Modeling Assumptions . . . . . . . . . . . . . . 57

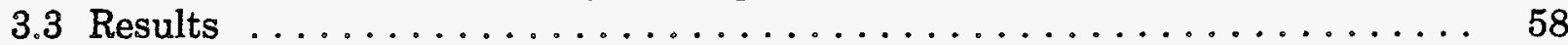

4 ACCIDENT ANALYSIS FOR TRANSURANIC WASTE . . . . . . . . . 63

5 ACCIDENT ANALYSIS FOR LOW-LEVEL WASTE $\ldots \ldots \ldots \ldots \ldots . \ldots \ldots$

5.1 Overview of Low-Level Waste Management . . . . . . . . . . . . . . 69

5.2 Risk-Dominant Accidents and Modeling Assumptions . . . . . . . . . 72

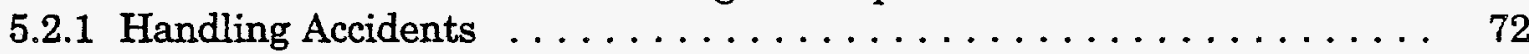

5.2 .2 Storage Facility Accidents $\ldots \ldots \ldots \ldots \ldots \ldots \ldots \ldots \ldots \ldots$

5.2.3 Treatment Facility and Inventory Modeling Assumptions . . . . . . 78

5.3 Results . . . . . . . . . . . . . . . . . . . . . . . 79

6 ACCIDENT ANALYSIS FOR LOW-LEVEL MIXED WASTE . . . . . . . . . . . 87

6.1 Overview of Low-Level Mixed Waste Management . . . . . . . . . . . 87

6.2 Risk-Dominant Accidents and Modeling Assumptions . . . . . . . . . . 92

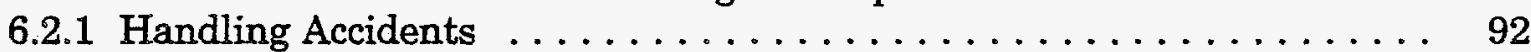

6.2 .2 Storage Facility Accidents $\ldots \ldots \ldots \ldots \ldots \ldots \ldots \ldots \ldots \ldots \ldots \ldots \ldots$

6.2.3 Treatment Facility and Inventory Modeling Assumptions . . . . . . 102

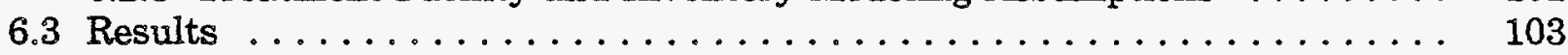

7 ACCIDENT ANALYSIS FOR GREATER-THAN-CLASS-C

LOW-LEVEL WASTE $\ldots \ldots \ldots \ldots \ldots \ldots \ldots \ldots \ldots \ldots \ldots \ldots$

7.1 Overview of Greater-Than-Class-C Low-Level Waste Management $\ldots \ldots \ldots$

7.2 Accident Considerations and Conclusions Relating to Source Terms . . . . . 118

8 ACCIDENT ANALYSIS FOR HAZARDOUS WASTE . . . . . . . . . . . . . 119

8.1 Overview of Hazardous Waste Management . . . . . . . . . . . . . . . 119

8.2 Risk-Dominant Accidents and Facility Modeling Assumptions . . . . . . . . 120

8.2.1 Packaged Waste Storage and Handling Operations . . . . . . . . 126

8.2 .2 Storage Facility Accidents . . . . . . . . . . . . . . . . . 129

8.2 .3 Treatment Facility Accidents . . . . . . . . . . . . . . 130

8.3 Results $\ldots \ldots \ldots \ldots \ldots \ldots \ldots \ldots \ldots \ldots \ldots \ldots \ldots \ldots$

9 REFERENCES $\ldots \ldots \ldots \ldots \ldots \ldots \ldots \ldots \ldots \ldots \ldots \ldots \ldots$ 


\section{FIGURES}

1.1 Overview of Facility Accident Analysis Interactions for the WM PEIS . . . . . 6

2.1 Major Components and Related Input and Output of Data for Facility Accident Analysis $\ldots \ldots \ldots \ldots \ldots \ldots \ldots \ldots$

2.2 Screening of Risk-Dominant Accident Sequences $\ldots \ldots \ldots \ldots \ldots \ldots$

2.3 Conceptual Flow Diagram for Source Term Development $\ldots \ldots \ldots \ldots$. . . . . 24

2.4 DOE Performance Goals for Hazard Category 1, 2, and 3 Facilities . . . . . . 29

2.5 Typical Design for Hazardous Waste Storage Facility $\ldots \ldots \ldots \ldots \ldots$

2.6 Plan of Generic Incineration Facility Assumed for Accident Analysis . . . . . . . 33

2.7 Computational Framework for Facility Accident Analysis Source Terms _. . . 49

5.1 LLW Management Technologies and Flow Paths $\ldots \ldots \ldots \ldots \ldots \ldots \ldots$

6.1 LLMW Baseline Treatment Flowsheet . . . . . . . . . . . . . . 91

\section{TABLES}

2.1 Risk-Dominant Accident-Initiator Categories for Waste Management

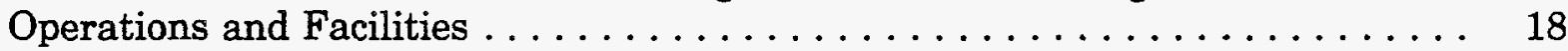

2.2 Frequency Classes Traditionally Considered in Safety Documentation . . . . . . 19

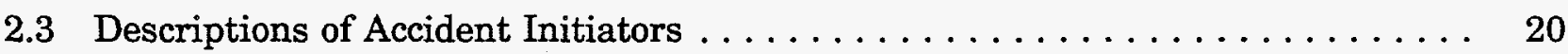

2.4 Frequency and Source Term Parameters for General Handling and Internal Facility Accidents $\ldots \ldots \ldots \ldots \ldots$

2.5 Representative Accidents Analyzed for Source Term Development . . . . . . . 51

3.1 Interim Storage Facilities for HLW Canisters . . . . . . . . . . . . . 54

3.2 Programmatic Alternatives for $\mathrm{HLW} \ldots \ldots \ldots \ldots \ldots \ldots$

3.3 Dimensions, Weights, and Radioactivities of HLW Canisters . . . . . . . 58

3.4 Respirable Airborne Release Fraction as a Function of Filtration for WM HLW Storage Facility Accidents 


\section{TABLES (Cont.)}

3.5 Mapping of HLW Treatability Categories with Accident Analysis

Physical Forms . . . . . . . . . . . . . . . . . . . .

3.6 Frequencies and Source Term Parameters for WM HLW Storage

Facility Accidents . . . . . . . . . . . . . . . . . . . .

4.1 Representative Accidents and Source Term Parameters from Recent

DOE Safety Analysis Documents Relevant to TRUW Storage ...........

5.1 Programmatic Alternatives for LLW Management . . . . . . . . . . . . . . 70

5.2 Mapping of LLW Treatability Categories with Accident Analysis

Physical Forms . . . . . . . . . . . . . . . . . . . . . . 74

5.3 Summary of WM LLW Accidents Analyzed . . . . . . . . . . . . 80

5.4 Frequencies and Source Term Parameters for WM LLW

Drum Handling Accidents . . . . . . . . . . . . . . . . .

5.5 Frequencies and Source Term Parameters for WM LLW

Incineration Facility Accidents $\ldots \ldots \ldots \ldots \ldots \ldots \ldots \ldots \ldots$

6.1 Specification of LLMW Alternatives $\ldots \ldots \ldots \ldots \ldots \ldots \ldots \ldots$

6.2 Generic Treatment Categories and Descriptions $\ldots \ldots \ldots \ldots \ldots$

6.3 Mapping of LLMW Treatability Categories with Accident Analysis

Physical Forms . . . . . . . . . . . . . . . . . . . . . . 93

6.4 Chemical Releases Analyzed for LLMW . . . . . . . . . . . . . . . 96

6.5 Representative Accidents and Source Term Parameters from Recent

DOE Safety Analysis Documents Relevant to LLMW . . . . . . . . . . . . . . . 101

6.6 Summary of WM LLMW Radiological Accidents Analyzed . . . . . . . . . . 105

6.7 Frequencies and Radiological Source Term Parameters for WM LLMW

Drum Handling Accidents . . . . . . . . . . . . . . . . . 108

6.8 Frequencies and Radiological Source Term Parameters

for WM LLMW Non-Alpha Incineration Facility Accidents . . . . . . . . . 110

6.9 Frequencies and Radiological Source Term Parameters

for WM LLMW Alpha-Incineration Facility Accidents . . . . . . . . . . 115

8.1 Specification of $\mathrm{HW}$ Alternatives $\ldots \ldots \ldots \ldots \ldots \ldots \ldots \ldots \ldots$ 


\section{TABLES (Cont.)}

8.2 Airborne Release Assumptions for Representative HW Accidents . . . . . . . 123

8.3 Site-Dependent Annual Frequencies of Representative HW Handling Accidents . . . . . . . . . . . . . . . . . . . . . . 132

8.4 Frequencies and Source Term Parameters for WM HW Storage Facility Accidents

8.5 Frequencies and Source Term Parameters for WM HW Incineration Facility Accidents

\section{VOLUME 2}

APPENDIX A: CHEMICAL SOURCE TERMS FOR LOW-LEVEL MIXED WASTE ACCIDENTS

A.1 INTRODUCTION $\ldots \ldots \ldots \ldots \ldots \ldots \ldots \ldots \ldots \ldots \ldots \ldots \ldots \ldots \ldots \ldots \ldots \ldots$

APPENDIX B: RADIONUCLIDE RELEASES FROM FACILITY ACCIDENTS

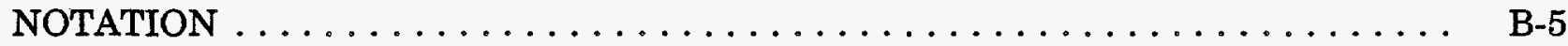

B.1 INTRODUCTION $\ldots \ldots \ldots \ldots \ldots \ldots \ldots \ldots \ldots \ldots \ldots \ldots \ldots \ldots \ldots \ldots \ldots \ldots \ldots$

B.2 RADIONUCLIDE RELEASES FROM FACILITY ACCIDENTS

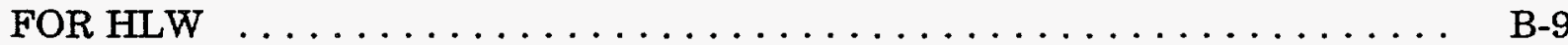

B.3 RADIONUCLIDE RELEASES FROM FACILITY ACCIDENTS FOR TRUW

B.4 RADIONUCLIDE RELEASES FROM FACILITY ACCIDENTS FOR LLW

B.5 RADIONUCLIDE RELEASES FROM FACILITY ACCIDENTS FOR ALPHA-LLMW TREATMENT

B.6 RADIONUCLIDE RELEASES FROM FACILITY ACCIDENTS FOR NON-ALPHA-LLMW TREATMENT

B.7 RADIONUCLIDE RELEASES FROM LLMW DRUM HANDLING ACCIDENTS 


\section{TABLES}

A.1 Frequencies and Chemical Source Terms for WM-LLMW

Drum Handling Accidents $\ldots \ldots \ldots \ldots \ldots \ldots \ldots \ldots \ldots \ldots \ldots \ldots \ldots$

A.2 Frequencies and Chemical Source Terms for WM-LLMW Non-Alpha

Incineration Facility Accidents . . . . . . . . . . . . . . . .

A.3 Frequencies and Chemical Source Terms for WM-LLMW Alpha

Incineration Facility Accidents . . . . . . . . . . . . . . . . . A-19

B.1 Accident Identification $\ldots \ldots \ldots \ldots \ldots \ldots \ldots \ldots \ldots \ldots \ldots \ldots \ldots \ldots \ldots \ldots$

B.2.1 High-Level Waste, All Cases: Hanford . . . . . . . . . . . . . B-11

B.2.2 High-Level Waste, All Cases: Savannah River Site $\ldots \ldots \ldots \ldots \ldots \ldots$ B-12

B.2.3 High-Level Waste, All Cases: West Valley Demonstration Project . . . . . . B-13

B.4.1 Low-Level Waste, Case 1: Idaho National Engineering Laboratory . . . . . B B-17

B.4.2 Low-Level Waste, Case 1: Savannah River Site . . . . . . . . . . B-18

B.4.3 Low-Level Waste, Case 9: Fernald Environmental Management Project . . B B-19

B.4.4 Low-Level Waste, Case 9: Hanford $\ldots \ldots \ldots \ldots \ldots \ldots \ldots \ldots \ldots$ B-20

B.4.5 Low-Level Waste, Case 9: Idaho National Engineering Laboratory . . . . . B B-21

B.4.6 Low-Level Waste, Case 9: Lawrence Livermore National Laboratory . . . . . B-22

B.4.7 Low-Level Waste, Case 9: Los Alamos National Laboratory . . . . . . . B-23

B.4.8 Low-Level Waste, Case 9: Oak Ridge National Laboratory . . . . . . . . . B B-24

B.4.9 Low-Level Waste, Case 9: Paducah Gaseous Diffusion Plant . . . . . . . B B-25

B.4.10 Low-Level Waste, Case 9: Portsmouth Gaseous Diffusion Plant . . . . . . B-26

B.4.11 Low-Level Waste, Case 9: Rocky Flats Environmental Technology Site . . . B-26

B.4.12 Low-Level Waste, Case 9: Savannah River Site . . . . . . . . . . B-27

B.4.13 Low-Level Waste, Case 12: Hanford . . . . . . . . . . . . . . . . . B-28

B.4.14 Low-Level Waste, Case 12: Idaho National Engineering Laboratory . . . . . B-29

B.4.15 Low-Level Waste, Case 12: Los Alamos National Laboratory . . . . . . . . . . B-30 


\section{TABLES (Cont.)}

B.4.16 Low-Level Waste, Case 12: Oak Ridge National Laboratory . . . . . . . . . B-31

B.4.17 Low-Level Waste, Case 12: Portsmouth Gaseous Diffusion Plant . . . . . . B-32

B.4.18 Low-Level Waste, Case 12: Rocky Flats Environment Technology Site .... B-33

B.4.19 Low-Level Waste, Case 12: Rocky Flats Environmental Technology Site . . B-34

B.4.20 Low-Level Waste, Case 12: Savannah River Site . . . . . . . . . . . . . B-35

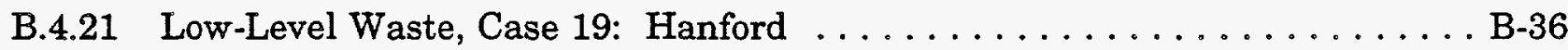

B.4.22 Low-Level Waste, Case 19: Idaho National Engineering Laboratory . . . . . B-37

B.4.23 Low-Level Waste, Case 19: Idaho National Engineering Laboratory . . . . . B-38

B.4.24 Low-Level Waste, Case 19: Oak Ridge National Laboratory . . . . . . . . B B-39

B.4.25 Low-Level Waste, Case 19: Savannah River Site . . . . . . . . . . . . . . B-40

B.4.26 Low-Level Waste, Case 21: Hanford . . . . . . . . . . . . . . . B-41

B.4.27 Low-Level Waste, Case 21: Hanford . . . . . . . . . . . . . . . . . . . B-42

B.4.28 Low-Level Waste, All Cases: Hanford . . . . . . . . . . . . . . . . B-43

B.4.29 Low-Level Waste, All Cases: Idaho National Engineering Laboratory . . . . B-44

B.4.30 Low-Level Waste, All Cases: Los Alamos National Laboratory . . . . . . . . B-45

B.4.31 Low-Level Waste, All Cases: Lawrence Livermore National Laboratory . . B-46

B.4.32 Low-Level Waste, All Cases: Oak Ridge National Laboratory . . . . . . . . B-47

B.4.33 Low-Level Waste, All Cases: Paducah Gaseous Diffusion Plant . . . . . . . B-48

B.4.34 Low-Level Waste, All Cases: Pantex Plant . . . . . . . . . . . . . . . . . B-48

B.4.35 Low-Level Waste, All Cases: Portsmouth Gaseous Diffusion Plant . . . . . B-49

B.4.36 Low-Level Waste, All Cases: Rocky Flats Plant . . . . . . . . . . . . . . . . . . B-49

B.4.37 Low-Level Waste, All Cases: Savannah River Site . . . . . . . . . . . . . . . B-50

B.5.1 Low-Level Mixed Waste, Case 2: Idaho National Engineering Laboratory .. B-51

B.5.2 Low-Level Mixed Waste, Case 2: Los Alamos National Laboratory . . . . . B-52 


\section{TABLES (Cont.)}

B.5.3 Low-Level Mixed Waste, Case 2: Lawrence Livermore National Laboratory B-53

B.5.4 Low-Level Mixed Waste, Case 2: Rocky Flats Environmental

Technology Site ............................. B-53

B.5.5 Low-Level Mixed Waste, Case 2: Savannah River Site . . . . . . . . . . B-54

B.5.6 Low-Level Mixed Waste, Case 4: Idaho National Engineering Laboratory .. B-55

B.5.7 Low-Level Mixed Waste, Case 4: Lawrence Livermore National

Laboratory . . . . . . . . . . . . . . . . . . . . B-56

B.5.8 Low-Level Mixed Waste, Case 4: Los Alamos National Laboratory . . . . . B-56

B.5.9 Low-Level Mixed Waste, Case 4: Rocky Flats Environmental

Technology Site . . . . . . . . . . . . . . . . . . . . B -57

B.5.10 Low-Level Mixed Waste, Case 4: Savannah River Site . . . . . . . . . . B-57

B.5.11 Low-Level Mixed Waste, Case 7: Idaho National Engineering Laboratory . . B-58

B.5.12 Low-Level Mixed Waste, Case 7: Los Alamos National Laboratory ... . . . B-58

B.5.13 Low-Level Mixed Waste, Case 7: Rocky Flats Environmental

Technology Site .......................... B-59

B.5.14 Low-Level Mixed Waste, Case 7: Savannah River Site . . . . . . . . . B-59

B.5.15 Low-Level Mixed Waste, Case 15: Idaho National Engineering

Laboratory . . . . . . . . . . . . . . . . . . . . . . . . B-60

B.5.16 Low-Level Mixed Waste, Case 15: Savannah River Site . . . . . . . . . . B-62

B.5.17 Low-Level Mixed Waste, Case 17: Hanford . . . . . . . . . . . . . . . B-62

B.5.18 Low-Level Mixed Waste, Case 26: Idaho National Engineering

Laboratory . . . . . . . . . . . . . . . . . . . . . . B 63

B.6.1 Low-Level Mixed Waste, Case 1: Idaho National Engineering Laboratory .. B-65

B.6.2 Low-Level Mixed Waste, Case 1: Oak Ridge National Laboratory . . . . . . B-66

B.6.3 Low-Level Mixed Waste, Case 1: Savannah River Site . . . . . . . . . . B-67

B.6.4 Low-Level Mixed Waste, Case 2: Argonne National Laboratory-East . . . . . B-68

B.6.5 Low-Level Mixed Waste, Case 2: Brookhaven National Laboratory . . . . . B-69 


\section{TABLES (Cont.)}

B.6.6 Low-Level Mixed Waste, Case 2: Energy Technology Engineering Center . . B-70

B.6.7 Low-Level Mixed Waste, Case 2: Fernald Environmental Management

Project . . . . . . . . . . . . . . . . . . . . . . . .

B.6.8 Low-Level Mixed Waste, Case 2: Hanford $\ldots \ldots \ldots \ldots \ldots \ldots \ldots \ldots$ B-71

B.6.9 Low-Level Mixed Waste, Case 2: Idaho National Engineering Laboratory . . B-72

B.6.10 Low-Level Mixed Waste, Case 2: Knolls Atomic Power Laboratory,

Schenectady . . . . . . . . . . . . . . . . . . $\ldots \ldots \ldots$

B.6.11 Low-Level Mixed Waste, Case 2: Oak Ridge National Laboratory . . . . . . B B-74

B.6.12 Low-Level Mixed Waste, Case 2: Paducah Gaseous Diffusion Plant . . . . . . B-75

B.6.13 Low-Level Mixed Waste, Case 2: Pantex Plant $\ldots \ldots \ldots \ldots \ldots \ldots$ B-76

B.6.14 Low-Level Mixed Waste, Case 2: Portsmouth Gaseous Diffusion Plant . . . B-76

B.6.15 Low-Level Mixed Waste, Case 2: Sandia National Laboratory-

New Mexico ............................ B-77

B.6.16 Low-Level Mixed Waste, Case 2: Savannah River Site $\ldots \ldots \ldots \ldots \ldots$ B-78

B.6.17 Low-Level Mixed Waste, Case 4: Energy Technology Engineering Center . . B-79

B.6.18 Low-Level Mixed Waste, Case 4: Fernald Environmental Management Project . . . . . . . . . . . . . . . .

B.6.19 Low-Level Mixed Waste, Case 4: Hanford $\ldots \ldots \ldots \ldots \ldots \ldots \ldots$ B-81

B.6.20 Low-Level Mixed Waste, Case 4: Idaho National Engineering Laboratory . . B-82

B.6.21 Low-Level Mixed Waste, Case 4: Lawrence Livermore National

Laboratory . . . . . . . . . . . . . . . .

B.6.22 Low-Level Mixed Waste, Case 4: Los Alamos National Laboratory . . . . . B B-84

B.6.23 Low-Level Mixed Waste, Case 4: Oak Ridge National Laboratory . . . . . . B-85

B.6.24 Low-Level Mixed Waste, Case 4: Paducah Gaseous Diffusion Plant . . . . . . B-86

B.6.25 Low-Level Mixed Waste, Case 4: Pantex Plant $\ldots \ldots \ldots \ldots \ldots \ldots$ B-86

B.6.26 Low-Level Mixed Waste, Case 4: Portsmouth Gaseous Diffusion Plant . . . B-87 


\section{TABLES (Cont.)}

B.6.27 Low-Level Mixed Waste, Case 4: Rocky Flats Environmental Technology

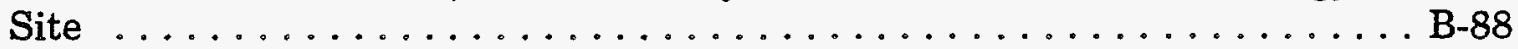

B.6.28 Low-Level Mixed Waste, Case 4: Savannah River Site . . . . . . . . . . . B-89

B.6.29 Low-Level Mixed Waste, Case 7: Hanford . . . . . . . . . . . . . . . . . . B-90

B.6.30 Low-Level Mixed Waste, Case 7: Idaho National Engineering Laboratory .. B-91

B.6.31 Low-Level Mixed Waste, Case 7: Los Alamos National Laboratory . . . . . B-92

B.6.32 Low-Level Mixed Waste, Case 7: Oak Ridge National Laboratory . . . . . . B-93

B.6.33 Low-Level Mixed Waste, Case 7: Portsmouth Gaseous Diffusion Plant .... B-94

B.6.34 Low-Level Mixed Waste, Case 7: Rocky Flats Environmental Technology Site .................................. . . . . . .

B.6.35 Low-Level Mixed Waste, Case 7: Savannah River Site . . . . . . . . . . . B-96

B.6.36 Low-Level Mixed Waste, Case 15: Hanford . . . . . . . . . . . . . . . B-97

B.6.37 Low-Level Mixed Waste, Case 15: Idaho National Engineering

Laboratory . . . . . . . . . . . . . . . . . . . . . . . B-98

B.6.38 Low-Level Mixed Waste, Case 15: Oak Ridge National Laboratory . . . . . B-99

B.6.39 Low-Level Mixed Waste, Case 15: Savannah River Site . . . . . . . . . . B-100

B.6.40 Low-Level Mixed Waste, Case 17: Hanford . . . . . . . . . . . . . B-101

B.6.41 Low-Level Mixed Waste, Case 26: Hanford . . . . . . . . . . . . . . . B-102

B.6.42 Low-Level Mixed Waste, Case 26: Idaho National Engineering

Laboratory . . . . . . . . . . . . . . . . . . . . B-103

B.6.43 Low-Level Mixed Waste, Case 26: Oak Ridge National Laboratory . . . . . B-104

B.6.44 Low-Level Mixed Waste, Case 26: Savannah River Site . . . . . . . . . B-105

B.7.1 Low-Level Mixed Waste, All Cases: Ames Laboratory . . . . . . . . . . . . B-107

B.7.2 Low-Level Mixed Waste, All Cases: Argonne National Laboratory-East . . . B-107

B.7.3 Low-Level Mixed Waste, All Cases: Argonne National Laboratory-West . . B-108

B.7.4 Low-Level Mixed Waste, All Cases: Bettis Atomic Power Laboratory . . . B-108 


\section{TABLES (Cont.)}

B.7.5 Low-Level Mixed Waste, All Cases: Battelle Columbus Laboratory . . . . . B-109

B.7.6 Low-Level Mixed Waste, All Cases: Brookhaven National Laboratory . . . B-109

B.7.7 Low-Level Mixed Waste, All Cases: Charleston Naval Shipyard . . . . . B-110

B.7.8 Low-Level Mixed Waste, All Cases: Colonie Interim Storage . . . . . . . . B-110

B.7.9 Low-Level Mixed Waste, All Cases: Energy Technology

Engineering Center $\ldots \ldots \ldots \ldots \ldots \ldots \ldots \ldots \ldots \ldots \ldots \ldots \ldots \ldots \ldots \ldots$

B.7.10 Low-Level Mixed Waste, All Cases: Fernald Environmental

Management Project . . . . . . . . . . . . . . . . . . . B-111

B.7.11 Low-Level Mixed Waste, All Cases: General Atomics . . . . . . . . . . . B-112

B.7.12 Low-Level Mixed Waste, All Cases: Grand Junction Project Office . . . . B-112

B.7.13 Low-Level Mixed Waste, All Cases: Hanford . . . . . . . . . . . . . . . . B-113

B.7.14 Low-Level Mixed Waste, All Cases: Idaho National Engineering

Laboratory . . . . . . . . . . . . . . . . . . . . . . . . . . B-113

B.7.15 Low-Level Mixed Waste, All Cases: Inhalation Toxicology

Research Institute . . . . . . . . . . . . . . . . . . . . . B-114

B.7.16 Low-Level Mixed Waste, All Cases: Knolls Atomic Power Laboratory . . . B-114

B.7.17 Low-Level Mixed Waste, All Cases: Kansas City Plant . . . . . . . . . . B-115

B.7.18 Low-Level Mixed Waste, All Cases: Knolls-Kesselring Site . . . . . . . . B-115

B.7.19 Low-Level Mixed Waste, All Cases: Knolls-Windsor Site . . . . . . . . . . B-116

B.7.20 Low-Level Mixed Waste, All Cases: Los Alamos National Laboratory . . . B-116

B.7.21 Low-Level Mixed Waste, All Cases: Lawrence Berkeley Laboratories . . . B-117

B.7.22 Low-Level Mixed Waste, All Cases: Lab for Energy Related

Health Research . . . . . . . . . . . . . . . . . . . . . . . . . . B-117

B.7.23 Low-Level Mixed Waste, All Cases: Lawrence Livermore

National Laboratory . . . . . . . . . . . . . . . . . . . . . . . . B-118

B.7.24 Low-Level Mixed Waste, All Cases: Mare Island Naval Shipyard . . . . . B-118

B.7.25 Low-Level Mixed Waste, All Cases: Mound Facility . . . . . . . . . . . . . B-119 


\section{TABLES (Cont.)}

B.7.26 Low-Level Mixed Waste, All Cases: Norfolk Naval Shipyard . . . . . . . . B B-119

B.7.27 Low-Level Mixed Waste, All Cases: Nevada Test Site . . . . . . . . . . . B-120

B.7.28 Low-Level Mixed Waste, All Cases: Oak Ridge National Laboratory . . . . B-120

B.7.29 Low-Level Mixed Waste, All Cases: Paducah Gaseous Diffusion Plant . . B-121

B.7.30 Low-Level Mixed Waste, All Cases: Pantex Plant . . . . . . . . . . . . B-121

B.7.31 Low-Level Mixed Waste, All Cases: Pearl Harbor Naval Shipyard . . . . B-122

B.7.32 Low-Level Mixed Waste, All Cases: Portsmouth Naval Shipyard . . . . . . B-122

B.7.33 Low-Level Mixed Waste, All Cases: Portsmouth Gaseous Diffusion Plant . B-123

B.7.34 Low-Level Mixed Waste, All Cases: Princeton Plasma Physics Laboratory B-123

B.7.35 Low-Level Mixed Waste, All Cases: Puget Sound Naval Shipyard . . . . . . B-124

B.7.36 Low-Level Mixed Waste, All Cases: Rocky Flats Plant . . . . . . . . B-124

B.7.37 Low-Level Mixed Waste, All Cases: Reactive Materials, Inc. . . . . . . . B-125

B.7.38 Low-Level Mixed Waste, All Cases: Sandia National Laboratories New Mexico ............................... 125

B.7.39 Low-Level Mixed Waste, All Cases: Sandia National Laboratories -

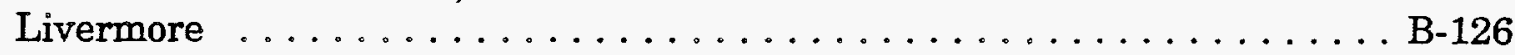

B.7.40 Low-Level Mixed Waste, All Cases: Savannah River Site . . . . . . . . B-126

B.7.41 Low-Level Mixed Waste, All Cases: University of Missouri, Columbia . . . B-127

B.7.42 Low-Level Mixed Waste, All Cases: West Valley Demonstration Project . . B-127 


\section{VOLUME 3}

APPENDIX C: REFERENCE DATA ON FIRES, EXPLOSIONS, AND

CRITICALITIES IN NUCLEAR AND CHEMICAL

PROCESSING AND WASTE MANAGEMENT FACILITIES

NOTATION

C.1 INTRODUCTION AND SUMMMARY

C.2 RECENT EXPLOSIONS OR FIRES AT HAZARDOUS WASTE

INCINERATION FACILITIES

C.3 REFERENCES

APPENDIX D: REFERENCE DATA ON RESPIRABLE AIRBORNE RELEASE FRACTIONS AND LEAK PATH FACTORS

NOTATION

D.1 RESPIRABLE AIRBORNE RELEASE FRACTION

D.1.1 Background

D.1.2 Airborne Release Fractions, Respirable Fractions, and Respirable Airborne Release Fractions

D.2 LEAK PATH FACTORS $\ldots \ldots \ldots \ldots \ldots \ldots \ldots \ldots \ldots \ldots \ldots \ldots \ldots$

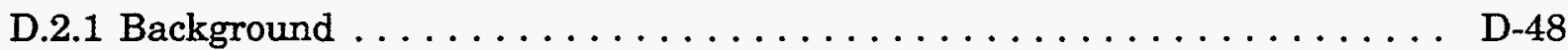

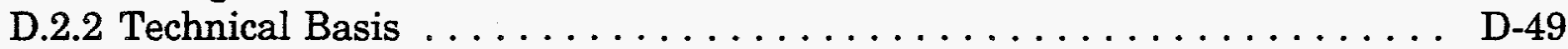

D.2.3 Application to WM PEIS $\ldots \ldots \ldots \ldots \ldots \ldots \ldots \ldots \ldots \ldots \ldots \ldots$

D.3 MAPPING OF WM PEIS TREATABILITY CATEGORIES WITH PHYSICAL FORM CATEGORIES FOR ACCIDENT ANALYSIS . . . . . . . . . . D-50

D.4 REFERENCES $\ldots \ldots \ldots \ldots \ldots \ldots \ldots \ldots \ldots \ldots \ldots \ldots \ldots \ldots \ldots \ldots$

APPENDIX E: REFERENCE DATA ON NATURAL PHENOMENA

FREQUENCIES AND RELATED DESIGN

SPECIFICATIONS OF DOE FACILITIES

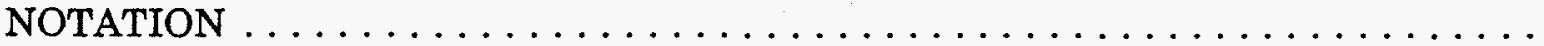

E.1 INTRODUCTION $\ldots \ldots \ldots \ldots \ldots \ldots \ldots \ldots \ldots \ldots \ldots \ldots \ldots \ldots \ldots \ldots$

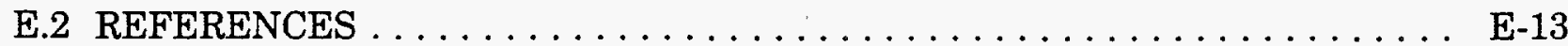


CONTENTS (Cont.)

APPENDIX F: EVALUATION OF AIR CRASH ACCIDENTS FOR U.S. DEPARTMENT OF ENERGY WASTE MANAGEMENT FACILITIES

NOTATION F-5

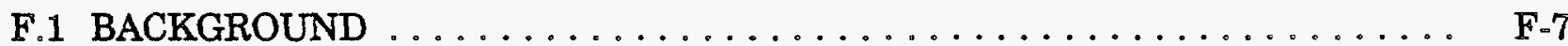

F.2 METHODOLOGY ......................... F-8

F.2.1 Crash Probability Estimates $\ldots \ldots \ldots \ldots \ldots \ldots \ldots \ldots \ldots \ldots \ldots$ F-11

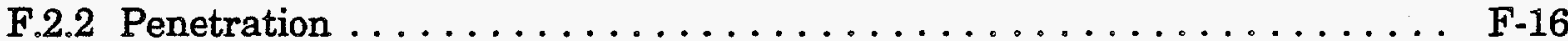

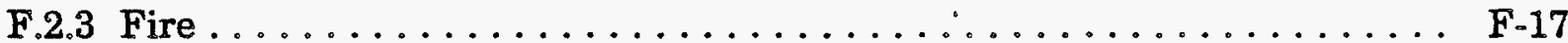

F.2.4 Presence of Radioactive Material $\ldots \ldots \ldots \ldots \ldots \ldots \ldots \ldots \ldots$ F-17

F.3 SUMMARY OF AIRCRAFT CRASH FREQUENCIES PER UNIT

OF LAND SURFACE $\ldots \ldots \ldots \ldots \ldots \ldots \ldots \ldots \ldots \ldots \ldots \ldots \ldots$ F-18

F.4 AIRCRAFT CRASH FREQUENCY FOR WM PEIS FACILITIES $\ldots \ldots \ldots \ldots$ F-18

F.4.1 Facility Target Area ..................... F-19

F.4.2 Frequency of Aircraft Crashes Against Facilities at DOE Sites ...... F-21

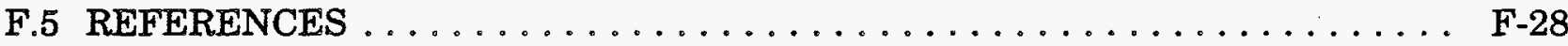

APPENDIX G: MODELING OF EXTERNAL EVENTS

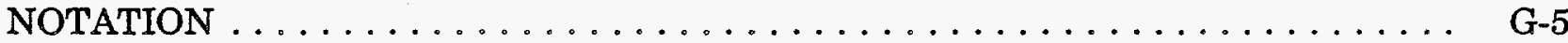

G.1 INTRODUCTION $\ldots \ldots \ldots \ldots \ldots \ldots \ldots \ldots \ldots \ldots \ldots \ldots \ldots \ldots \ldots \ldots \ldots$

G.2 STORAGE FACILITY ACCIDENTS $\ldots \ldots \ldots \ldots \ldots \ldots \ldots \ldots \ldots$ G-8

G.2.1 Specification and Frequency Evaluation of Accident Sequences ...... G-8

G.2.2 Evaluation of Source Term Parameters . . . . . . . . . . . G-15

G.3 TREATMENT FACILITY ACCIDENTS $\ldots \ldots \ldots \ldots \ldots \ldots \ldots \ldots \ldots$ G-17

G.3.1 Specification and Frequency Evaluation of Accident Sequences . . . . . . G-17

G.3.2 Evaluation of Source Term Parameters for Treatment Facilities . . . . . . G-22

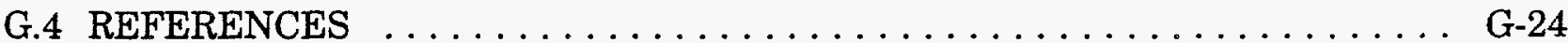




\section{CONTENTS (Cont.)}

APPENDIX H: REFERENCE DATA ON AIRBORNE RELEASES FOR ACCIDENTS INVOLVING HAZARDOUS CHEMICALS

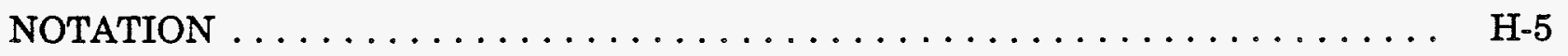

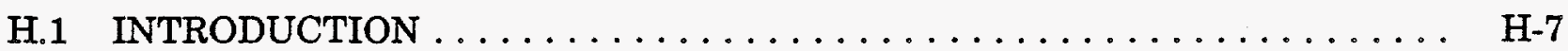

H.2 HANDLING ACCIDENT IN WHICH AQUEOUS AMMONIA

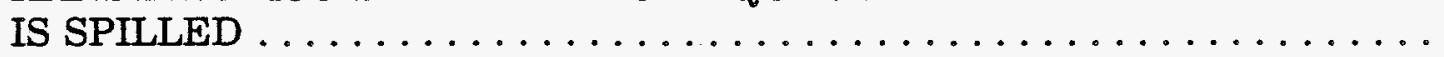

H.3 HANDLING ACCIDENT IN WHICH HYDROCHLORIC ACID IS SPILLED $\ldots \ldots \ldots \ldots \ldots \ldots \ldots \ldots \ldots \ldots \ldots \ldots \ldots \ldots \ldots \ldots \ldots \ldots \ldots \ldots$

H.4 HANDLING ACCIDENT IN WHICH AQUEOUS HYDROGEN FLUORIDE IS SPILLED $\ldots \ldots \ldots \ldots \ldots \ldots \ldots \ldots \ldots \ldots \ldots \ldots \ldots \ldots$

H.5 HANDLING ACCIDENT IN WHICH NITRIC ACID IS SPILLED . . . . . . H-10

H.6 HANDLING ACCIDENT IN WHICH AN AROMATIC HYDROCARBON SPILLS AND BURNS

H.7 HANDLING ACCIDENT IN WHICH A FLAMMABLE LIQUID SPILLS, IGNITES, AND BURNS, CAUSING THE RUPTURE OF OTHER CONTAINERS

H.8 HANDLING ACCIDENT IN WHICH A FLAMMABLE LIQUID SPILLS AND IGNITES; THE FIRE ENGULFS NEARBY DRUMS AND INITIATES REACTIONS THAT RELEASE HIGHLY TOXIC VAPORS H-13

H.9 LARGER ACCIDENT IN WHICH A FLAMMABLE LIQUID SPILLS

AND IGNITES; THE FIRE ENGULFS NEARBY DRUMS AND INITIATES REACTIONS THAT RELEASE TOXIC VAPORS

H.10 HEAT FROM THE FIRE CAUSES AN EXPLOSION IN A COMPRESSED GAS CONTAINER, RESULTING IN VENTING OF A TOXIC GAS . . . . . H H

H.11 ACCIDENTAL CO-CONFINEMENT OF OXIDIZING AND REDUCING AGENTS, LEADING TO A REACTION GENERATING HEAT THAT IGNITES PACKAGING AND BREACHES A NEARBY DRUM

H.12 ACCIDENTAL CONFINEMENT OF WATER WITH ALKALI METALS, ALKALI-METAL HYDRIDES, OR ALKALINE-EARTH OXIDES, GIVING REACTIONS GENERATING HEAT, IGNITING PACKAGING, AND BREACHING NEARBY DRUMS 


\section{CONTENTS (Cont.)}

H.13 ACCIDENTAL RUPTURE OF COMPRESSED GAS DUE TO VALVE FAILURE, RESULTING IN RELEASES OF TOXIC GAS

H.14 EXPLOSION OF A STORED CHEMICAL

H.15 HANDLING ACCIDENTS IN WHICH A SPILLED WASTE RELEASES A MUTAGENIC, TERATOGENIC, OR CARCINOGENIC SUBSTANCE

H.16 HANDLING ACCIDENT SPILL THAT IGNITES FLAMMABLE LIQUIDS, THEREBY BREACHING NEARBY DRUMS WITH CADMIUMCONTAINING COMPOUNDS

H.17 HANDLING ACCIDENT SPILL THAT IGNITES FLAMMABLE LIQUID; THE FIRE BREACHES NEARBY DRUMS CONTAINING DICHROMATE SALTS

\section{FIGURES}

E.1 Relationship among Hazard Class/Category, SSC Performance Category, and Pertinent DOE Orders and Standards

F.1 Generic Representation of Takeoff and Landing Sectors $\ldots \ldots \ldots \ldots \ldots$ F-9

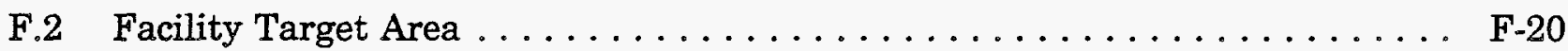

G.1 Event Tree for Small-Aircraft Impact on Generic Storage Facility

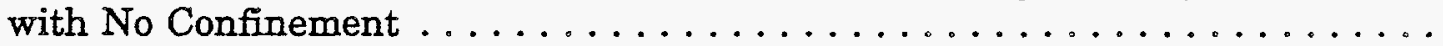

G.2 Event Tree for Large-Aircraft Impact on Generic Storage Facility with No Confinement

G.3 Event Tree for Seismic Challenge to Generic Storage Facility with No Confinement

G.4 Event Tree for Small-Aircraft Impact on Generic DOE Hazard Category 2 Incineration Facility

G.5 Event Tree for Large-Aircraft Impact on Generic DOE Hazard Category 2 Incineration Facility

G.6 Event Tree for Seismic Challenge to Generic DOE Hazard Category 2 Incineration Facility 


\section{TABLES}

C.1 Postulated Fires and Explosions in Treatment, Storage, and Disposal

Facilities . . . . . . . . . . . . . . .

C.2 Summary of Fire and Explosion Sources $\ldots \ldots \ldots \ldots \ldots \ldots \ldots \ldots$ C-13

C.3 Postulated Criticalities in Treatment, Storage, and Disposal Facilities $\ldots \ldots \ldots \ldots \ldots \ldots \ldots \ldots \ldots \ldots \ldots \ldots \ldots \ldots \ldots \ldots \ldots \ldots \ldots \ldots, 14$

C.4 Summary of Criticality Accident Fission Yields $\ldots \ldots \ldots \ldots \ldots \ldots \ldots$ C-15

C.5 Summary of Fires, Explosions, and Incidents of Drum Overpressurization .......................... C-16

D.1 Summary of Release Fraction Parameters Abstracted from

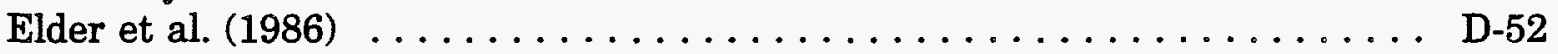

D.2 WM PEIS Waste RARFs: Physical Type or Subcategory versus Stress $\ldots . \quad$ D-53

D.3 WM PEIS Waste RARFs for LLW, LLMW, and TRUW Storage and Handling $\ldots \ldots \ldots \ldots \ldots \ldots \ldots \ldots \ldots \ldots \ldots \ldots \ldots \ldots$

D.4 WM PEIS Waste RARFs for LLW Processing by Incineration $\ldots \ldots \ldots \ldots$ D-57

D.5 WM PEIS Waste RARFs for HLW Processing and Storage $\ldots \ldots \ldots \ldots \ldots$ D-60

D.6 Threshold Values of Differential Pressure Required to Structurally Damage Standard HEPA Filter $\ldots \ldots \ldots \ldots \ldots \ldots \ldots \ldots \ldots \ldots \ldots \ldots \ldots \ldots \ldots$

D.7 Effects of Environmental Filter Parameters on Aerosol Penetration through HEPA Filters $\ldots \ldots \ldots \ldots \ldots \ldots \ldots \ldots \ldots \ldots \ldots \ldots \ldots \ldots$

D.8 Summary of Reduction and Removal Factors Abstracted from

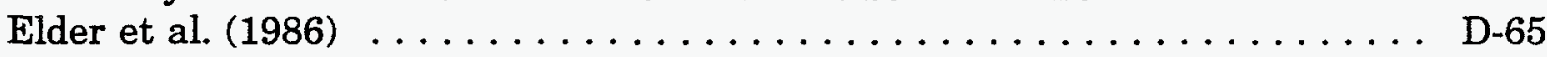

D.9 Mapping of WM PEIS Treatability Categories for LLW with Accident Analysis Physical Forms $\ldots \ldots \ldots \ldots \ldots \ldots \ldots \ldots \ldots \ldots \ldots \ldots \ldots \ldots \ldots \ldots$

D.10 Mapping of WM PEIS Treatability Categories for TRUW with Accident

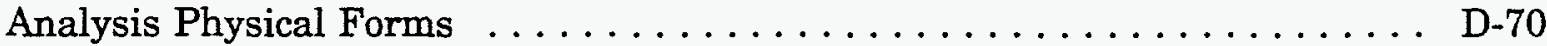

D.11 Mapping of WM PEIS Treatability Categories for HLW with Accident

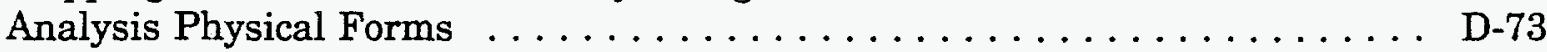

E.1 Natural Phenomena Hazards Performance Goals for Systems, Structures,

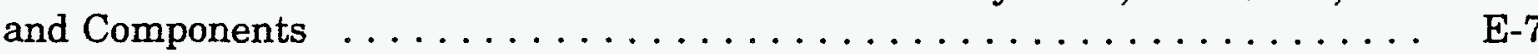

E.2 Natural Phenomena Frequency and Intensity Data for DOE Sites $\ldots \ldots \ldots$ E-9 


\section{TABLES (Cont.)}

F.1 Probabilities of a Fatal Crash $\ldots \ldots \ldots \ldots \ldots \ldots \ldots \ldots \ldots \ldots \ldots \ldots \ldots \ldots \ldots \ldots$

F.2 Principal DOE Waste Management Sites $\ldots \ldots \ldots \ldots \ldots \ldots \ldots \ldots \ldots$ F-12

F.3 Airports near DOE Sites and their Potentials to Increase Aircraft Accident Frequencies $\ldots \ldots \ldots \ldots \ldots \ldots \ldots \ldots \ldots \ldots \ldots$ F-13

F.4 Estimated Annual Overflight Frequencies of DOE Sites . . . . . . . . F F-14

F.5 Estimated Annual Crash Probabilities at DOE Sites from Commercial Aviation Operations at Nearby Airports . . . . . . . . . . . . . F 15

F.6 Estimated Annual Federal Airway Commercial Crash Probabilities . . . . . . F F-15

F.7 Estimated Annual Crash Probabilities at DOE Sites from General Aviation Operations at Nearby Airports . . . . . . . . . . . F-17

F.8 General Aviation Building Penetration Probabilities $\ldots \ldots \ldots \ldots \ldots \ldots$ F-17

F.9 Summary of Annual Aircraft Crash Frequencies for DOE Sites . . . . . . F-18

F.10 Summary of Annual Aircraft Crash Frequency Per Square Mile Grouped into APLL and APLS Crashes . . . . . . . . . . . . F-19

F.11 Effective Area Estimates for LLW, LLMW, TRUW, HLW, and

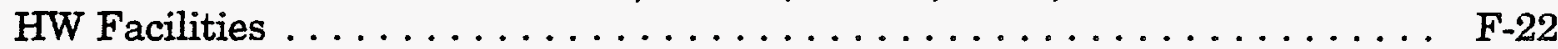

F.12 Airplane Impacts Initiating Event Frequency: LLW Storage . . . . . . . F F-23

F.13 Airplane Impacts Initiating Event Frequency: LLW Incineration

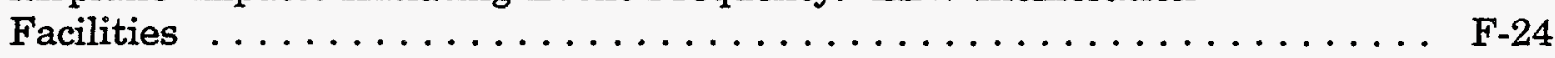

F.14 Airplane Impacts Initiating Event Frequency: HLW Facilities $\ldots \ldots \ldots \ldots$ F-24

F.15 Airplane Impacts Initiating Event Frequency: HW

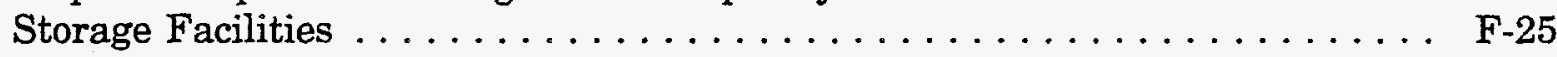

F.16 Airplane Impacts Initiating Event Frequency: HW Treatment Facilities . . . . . . . . . . . . . . . . . . .

F.17 Airplane Impacts Initiating Event Frequency: LLMW Storage Facilities

F.18 Airplane Impacts Initiating Event Frequency: LLMW Treatment Facilities 


\section{TABLES (Cont.)}

F.19 Airplane Impacts Initiating Event Frequency: TRUW

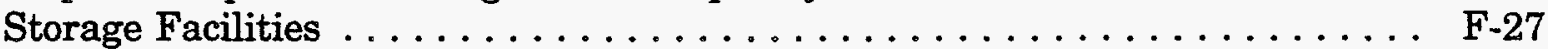

F.20 Airplane Impacts Initiating Event Frequency: TRUW Treatment Facilities . . . . . . . . . . . . . . . . . . . . . . F

G.1 Approximate Distribution of Incinerator Ash in the Generic Facility . . . . . G G-23 


\section{APPENDIX C:}

REFERENCE DATA ON FIRES, EXPLOSIONS, AND

CRITICALITIES IN NUCLEAR AND CHEMICAL PROCESSING AND WASTE MANAGEMENT FACILITIES 


\section{CONTENTS}

NOTATION C-5

C.1 INTRODUCTION AND SUMMARY $\ldots \ldots \ldots \ldots \ldots \ldots \ldots \ldots \ldots$ C-7

C.2 RECENT EXPLOSIONS OR FIRES AT HAZARDOUS WASTE INCINERATION FACILITIES

C.3 REFERENCES C-18

\section{TABLES}

C.1 Postulated Fires and Explosions in Treatment, Storage, and Disposal Facilities . . . . . . . . . . . . . . . . . . . . . . .

C.2 Summary of Fire and Explosion Sources . . . . . . . . . . . . C-13

C.3 Postulated Criticalities in Treatment, Storage, and Disposal Facilities .............................

C.4 Summary of Criticality Accident Fission Yields $\ldots \ldots \ldots \ldots \ldots \ldots \ldots$ C-15

C.5 Summary of Fires, Explosions, and Incidents of Drum Overpressurization . . . C-16 


\section{NOTATION}

The following is a list of acronyms, initialisms, and abbreviations (including units of measure) used in this appendix.

ACRONYMS, INITIALISMS, AND ABBREVIATIONS

GPC general purpose concentrator

$\mathrm{H}_{2} \quad$ hydrogen

$\mathrm{H}_{2} \mathrm{O}$ water

HEPA high-efficiency particulate air (filter)

HLLW high-level liquid waste

IIW intermediate-level waste

NA sodium

$\mathrm{NO}_{\mathrm{x}} \quad$ nitrogen oxides

$\mathrm{O}_{2} \quad$ oxygen

$\mathrm{Pu} \quad$ plutonium

$\mathrm{Ru} \quad$ ruthenium

$\mathrm{U}$ uranium

VOG vessel off-gas

\section{UNITS OF MEASURE}

$\begin{array}{ll}{ }^{\circ} \mathrm{C} & \text { degree(s) Celsius } \\ { }^{\circ} \mathrm{F} & \text { degree(s) Fahrenheit } \\ \mathrm{ft} & \text { foot (feet) } \\ \mathrm{J} & \text { joule(s) } \\ \mathrm{m} & \text { meter(s) }\end{array}$




\section{APPENDIX C:}

\section{REFERENCE DATA ON FIRES, EXPLOSIONS, AND CRITICALITIES IN NUCLEAR AND CHEMICAL PROCESSING AND WASTE MANAGEMENT FACHITIES}

\section{C.1 INTRODUCTION AND SUMMARY}

This appendix summarizes existing information that has been used to estimate the potential for and radiological consequences of fires, explosions, and nuclear criticalities that could occur in treatment, storage, and disposal facilities. Because almost all scenarios with radiological consequences that have measurable public health effects involve these mechanisms, this information, much of which is based on materials in Elder et al. (1986) and Ayer et al. (1988), is provided to complement the related discussions in the main text of this report.

Table C.1 lists plausible accidents involving fires and explosions in nuclear and chemical processing and waste management facilities, identifies conditions that could lead to their occurrence, and describes their potential consequences. Table C.2 identifies the categorization of fires, explosions, and their sources provided in Elder et al. (1986).

Table C.3 lists plausible criticality accidents, identifies conditions that could lead to their occurrence, and qualitatively describes their potential consequences. Table C.4 summarizes fission yields predicted from selected configurations that potentially could occur in U.S. Department of Energy facilities. Table C.5 summarizes fires, explosions, and incidents of drum overpressurization.

\section{C.2 RECENT EXPLOSIONS OR FIRES AT HAZARDOUS WASTE INCINERATION FACILITIES}

Hazardous waste incinerators that have experienced explosions are discussed in subsequent paragraphs; no explosion required community evacuation. Further, most explosions occurred in boilers or ducts downstream of the incinerators and thus did not involve the release of hazardous constituents. The summaries were compiled in April of 1994 by the U.S. Environmental Protection Agency (Hlustick 1994).

Rollins Deer Park, Deer Park, Texas. This fire occurred in November 1991 in the furnace duct, not the incinerator. The plant shut down as many vents as possible and allowed the facility a few days to cool down. A new duct was installed, and the plant was back up and running in about five days.

Ensco, El Dorado, Arkansas. This explosion occurred around September 1991 in the waste heat recovery boiler, not the incinerator. This unit was fairly old; excessive pressure had built up because of structure failure. As a result, the unit exploded. No extensive 
TABLE C.1 Postulated Fires and Explosions in Treatment, Storage, and Disposal Facilities

\begin{tabular}{lll}
\hline \multicolumn{1}{c}{ Accident } & Conditions Leading to Occurrence & Potential Consequences and Considerations \\
\hline General facility fire & $\begin{array}{l}\text { Poor housekeeping/administrative control; } \\
\text { quantity of fuel at location; strong } \\
\text { ignition source. }\end{array}$ & $\begin{array}{l}\text { Loss of glove box integrity (loss of gloves, glass or plastic } \\
\text { viewing windows); potential loss of airflow via filter } \\
\text { clogging; failure of piping and equipment from thermal } \\
\text { effects of pressurization of contents. }\end{array}$ \\
General cell fire & $\begin{array}{l}\text { Accumulation of combustible materials in } \\
\text { cell (e.g., plastics, dust, solvent leak, some } \\
\text { cloth, grease, organic film) and ignition; } \\
\text { cell window breaks and oil ignites. }\end{array}$ & $\begin{array}{l}\text { Cell filters clogged; all plastics in cell lose integrity; cell } \\
\text { operating and service areas; material transported to cell } \\
\text { fliters. }\end{array}$
\end{tabular}

Fires involving

- Stored combustible waste

- Combustible fluids

- Flammable gas or liquid

- Organics/lint in exhaust ducts

- Ion-exchange resin
Strong ignition source (in combustibles); pathway from drum to drum; violation of procedures (leaving drum uncovered).

Undetected leak; very strong ignition source or elevated temperature of fluid and ignition source.

Unauthorized use (violation of administrative control); careless use (excess vapor generation); leak; ignition source.

Exhaust ducts not routinely cleaned; ignition source.

Nitration of resin; ignition source.
Combustion of contaminated combustibles; generation of heat and combustion products.

Loss of glove box integrity (loss of gloves, glass or plastic viewing windows); potential loss of airflow via filter clogging; failure of piping and equipment from thermal effects of pressurization of contents.

Loss of glove box integrity (loss of gloves, plastic or glass viewing windows); heat/flame intrusion on equipment in box; potential loss of glove box filter (and ignition of organics/lint in exhaust ducts); potential clogging of filter and diffusion from glove box back into room.

Loss of final HEPA filters; loss of combustible exhaust ducts; potential ignition source for fires in other areas.

Catastrophic loss of glove box integrity; (loss of gloves, windows, inlet and outlet filters); damage to adjacent glove boxes and equipment; damage to structure; damage to exhaust ducts or filters in glove box. 
TABLE C.1 (Cont.)

\begin{tabular}{|c|c|c|}
\hline Accident & Conditions Leading to Occurrence & Potential Consequences and Considerations \\
\hline - Solvents & $\begin{array}{l}\text { High organic stream temperature; solvent } \\
\text { leak and vaporization or spray on hot } \\
\text { equipment (e.g., stream line, evaporator } \\
\text { reboiled); steam jet leak in solvent } \\
\text { recovery; solvent cooler failure; solvent } \\
\text { spills from skimmer, overflow, flooded } \\
\text { decanter, or makeup tank overflow; cell } \\
\text { atmosphere oxygen concentration above } \\
\text { limit; ignition source. }\end{array}$ & $\begin{array}{l}\text { Airborne activity in process cell; possible overheating and } \\
\text { plugging of cell ventilation filters; air reversal; loss of } \\
\text { process control; equipment damage. Energy release by } \\
\text { solvent burning somewhat limited by amount in process } \\
\text { cells. }\end{array}$ \\
\hline - Sodium (in handling) & $\begin{array}{l}\text { Sodium leak and loss of control of cell } \\
\text { atmosphere. }\end{array}$ & $\begin{array}{l}\text { Sodium smoke released to cell ventilation system with } \\
\text { possible pressurization of cell, ventilation filter failure; } \\
\text { local temperature to } 1,250^{\circ} \mathrm{C} \text {; any overheated fuel } \\
\text { elements could release noble gases, iodine, and volatiles. }\end{array}$ \\
\hline \multicolumn{3}{|l|}{ Explosions involving } \\
\hline - Solvent in glove box & $\begin{array}{l}\text { Unauthorized use (violation of } \\
\text { administrative control); careless use } \\
\text { (excess vapor generation); leak; } \\
\text { accumulation of substantial quantity of } \\
\text { flammable mixture. }\end{array}$ & $\begin{array}{l}\text { Catastrophic loss of glove box integrity; (loss of gloves, } \\
\text { windows, inlet and outlet filters); damage to adjacent } \\
\text { glove boxes and equipment; damage to structure; damage } \\
\text { to exhaust ducts or filters in glove box. }\end{array}$ \\
\hline - Hydrogen & $\begin{array}{l}\text { Accumulation of quantity of flammable } \\
\text { mixture prior to contact with ignition } \\
\text { source (failure of several protection } \\
\text { devices); ignition source. }\end{array}$ & $\begin{array}{l}\text { Catastrophic loss of glove box integrity; (loss of gloves, } \\
\text { windows, inlet and outlet filters); damage to adjacent } \\
\text { glove boxes and equipment; damage to structure; damage } \\
\text { to exhaust ducts or filters in glove box; damage dependent } \\
\text { upon quantity of gas involved and location of explosion. }\end{array}$ \\
\hline - Flammable gas & $\begin{array}{l}\text { Undetected leak in cylinder; accumulation } \\
\text { of quantity of flammable mixture prior to } \\
\text { contact with ignition source; ignition } \\
\text { source. }\end{array}$ & $\begin{array}{l}\text { Catastrophic to minor damage to enclosures, equipment } \\
\text { and structure; ignition of combustibles in area; damage } \\
\text { dependent upon quantity of gas involved and location of } \\
\text { explosion. }\end{array}$ \\
\hline
\end{tabular}


TABLE C.1 (Cont.)

\begin{tabular}{|c|c|c|}
\hline Accident & Conditions Leading to Occurrence & Potential Consequences and Considerations \\
\hline $\begin{array}{l}\text { - Red oil in concentrator from } \\
\text { solvent extraction system }\end{array}$ & $\begin{array}{l}\text { Undetected long-range accumulation of } \\
\text { solvent in concentrator; nitration of } \\
\text { solvent; temperature exceeding } 135^{\circ} \mathrm{C} \\
\text { after nitration. }\end{array}$ & $\begin{array}{l}\text { Loss of concentrator; loss of nearby equipment, and } \\
\text { piping; ignition of flammables and combustibles in area; } \\
\text { potential loss of structural components from blast and } \\
\text { pressure effects. }\end{array}$ \\
\hline - Ammonia & $\begin{array}{l}\text { Undetected leak in cylinder; accumulation } \\
\text { of quantity of flammable mixture prior to } \\
\text { contact with ignition source; ignition } \\
\text { source. }\end{array}$ & $\begin{array}{l}\text { Catastrophic loss of glove box integrity; (loss of gloves, } \\
\text { windows, inlet and outlet filters); damage to adjacent } \\
\text { glove boxes and equipment; damage to structure; damage } \\
\text { to exhaust ducts or filters in glove box. }\end{array}$ \\
\hline $\begin{array}{l}\text { Fire or explosion associated with } \\
\text { ion-exchange resin }\end{array}$ & $\begin{array}{l}\text { Self-heating of resin due to abnormal } \\
\text { conditions in column such as high nitric } \\
\text { acid concentration, column overloading, } \\
\text { dry resin in column, or high column } \\
\text { temperature; self heating of spent resin in } \\
\text { waste; spontaneous combustion of spilled } \\
\text { resins. }\end{array}$ & $\begin{array}{l}\text { Column pressurization and column rupture; eruption; } \\
\text { airborne activity in process cell; release of fission products } \\
\text { to ventilation system; waste fires; cell pressurization; } \\
\text { damage to equipment and to ventilation system; possible } \\
\text { plugging or overheating of VOG filters. }\end{array}$ \\
\hline Evaporator explosion & $\begin{array}{l}\text { Uncontrolled reaction in evaporator; } \\
\text { solvent in feed and loss of temperature } \\
\text { control; overpressurization of plutonium } \\
\text { evaporator, hydrogen accumulation, and } \\
\text { ignition source. }\end{array}$ & $\begin{array}{l}\text { Severe damage to equipment and VOG; possible missiles } \\
\text { in process cell; airborne activity released to process cell; } \\
\text { substantial amounts of aerosol generated; cell } \\
\text { pressurization. }\end{array}$ \\
\hline Hydrazoic acid explosion & $\begin{array}{l}\text { Uncontrolled reaction of hydrazide } \\
\text { products used in solvent recovery. }\end{array}$ & $\begin{array}{l}\text { Damage to VOG system; fire in solvent recovery; airborne } \\
\text { activity in process cell; cell pressurization. }\end{array}$ \\
\hline $\begin{array}{l}\text { Explosion in uranium } \\
\text { evaporator-denitrator system or in } \\
\text { concentrate evaporator }\end{array}$ & $\begin{array}{l}\text { Uncontrolled reaction caused by excessive } \\
\text { organic material in feed or loss of } \\
\text { temperature control in evaporators; oil } \\
\text { leak in denitrator; organic material in } \\
\text { feed to concentrate evaporators. }\end{array}$ & $\begin{array}{l}\text { Damage to equipment, } \mathrm{NO}_{\mathrm{x}} \text { absorber, and VOG system; } \\
\text { release of process material to cell and cell air; cell } \\
\text { pressurization. }\end{array}$ \\
\hline
\end{tabular}


TABLE C.1 (Cont.)

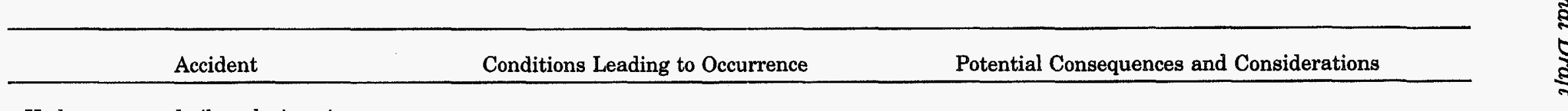

Hydrogen or red oil explosions in

- Product storage tank

- General tank or vessel vent system

- Process cell

- Fuel cleaning cells

- General purpose concentrator (GPC)

- High-level concentrator
Hydrogen produced by radiolysis of product solutions; loss of purge; ignition source.

Concentration of feed solution; hydrogen produced by radiolysis of feed solution; loss of purge to feed tank; oxygen and/or ignition source.

Ignition source and/or excessive oxygen present in cell atmosphere; hydrogen release to cell from $\mathrm{H}_{2}$ generator (e.g., leaks) or purifier catalyst poisoned causing excess oxygen in cell; emergency hydrogen supply system leak into cell.

Uncontrolled sodium reaction in fuel cleaning vessel; overloaded catalytic oxidizer; ignition of $\mathrm{H}_{2}$ in off-gas; loss of inert cell atmosphere (humidity control) during unloading of $\mathrm{Na}$-cooled fuel, uncontrolled $\mathrm{Na}-\mathrm{H}_{2} \mathrm{O}$ reaction in cell, or ignition of $\mathrm{H}_{2}$ in cell.

Simultaneous occurrence of all of the following: insufficient caustic added to GPC feed (acidic feed); excessive bottoms temperature $\left(>130^{\circ} \mathrm{C}\right)$; heavy metal present (e.g., uranium from analytical laboratory); solvent in feed.

Uncontrolled red oil reaction from all of the following: solvent in feed,

temperatures above $130^{\circ} \mathrm{C}$, heavy metal $(\mathrm{U}, \mathrm{Pu})$ present.
Damage to off-gas system and release of off-gas; other equipment damage; release of fissiles to cell floor; cell pressurization.

Severe damage to equipment; potential damage to off-gas system; release of radioactive material to process cell.

Damage to shielding cell, cell ventilation, and VOG systems; release of radioactive material from process cells to occupied areas; possible missiles; possible severe damage to equipment items in cell; initiation and development of additional major accident sequences (fires, etc.).

Damage to cell equipment and/or off-gas system; possible rupture of fuel element being cleaned with release of airborne activity to process cell ventilation system.

Release of ILW to cell floor; airborne ILW in process cell and cell exhaust; possible missiles; fire in cell; damage to VOG system; cell pressurization; release to occupied areas.

Rupture of concentrator would cause possibly violent ejection of liquid, with formation of aerosol; subsequent boil-off of residual liquid with release of volatile species and additional aerosol may occur. 
TABLE C.1 (Cont.)

\begin{tabular}{|c|c|c|}
\hline Accident & Conditions Leading to Occurrence & Potential Consequences and Considerations \\
\hline & $\begin{array}{l}\text { Hydrogen explosion from all of the } \\
\text { following: } \mathrm{H}_{2} \text { accumulation, } \mathrm{O}_{2} \\
\text { concentration above limit, and ignition } \\
\text { source. } \\
\text { Pressure buildup from all of the following: } \\
\text { VOG vent plugging, loss of temperature } \\
\text { control, pressurization. }\end{array}$ & $\begin{array}{l}\text { Damage to VOG treatment system; release to process } \\
\text { stack; cell pressurization and possible rupture producing } \\
\text { missiles; release to occupied areas. }\end{array}$ \\
\hline Rupture of a HLLW storage tank & $\begin{array}{l}\text { Corrosion/erosion; mechanical stress from } \\
\text { overpressurization or loss of cooling; } \\
\text { simultaneous failure of the VOG system } \\
\text { (e.g., by a } \mathrm{H}_{2} \text { explosion from loss of air } \\
\text { sparge). }\end{array}$ & $\begin{array}{l}\text { Release of HLLW to cell floor; airborne HLLW in process } \\
\text { cells; potential for large release to process stack if safety } \\
\text { features fail. } \\
\text { Self-heating liquid, if undrained, could boil away water } \\
\text { and acid; self-heating of resulting solids could melt and } \\
\text { damage containment in addition to producing fumes and } \\
\text { aerosols; decay energy content of } 75,000-\mathrm{L} \text { tank could be } \\
2.5 \mathrm{E}+6 \mathrm{~W} \text {. }\end{array}$ \\
\hline
\end{tabular}

Hydrogen explosion from all of the wing: $\mathrm{H}_{2}$ accumulation, $\mathrm{O}_{2}$

Pressure buildup from all of the following VOG vent plugging, loss of temperature overpressurization or loss of cooling simultaneous failure of the VOG system (e.g., by a $\mathrm{H}_{2}$ explosion from loss of air parge)

a Abbreviations: GPC = general purpose concentrator, $\mathrm{H}_{2}=$ hydrogen, $\mathrm{H}_{2} \mathrm{O}=$ water, $\mathrm{HEPA}=$ high efficiency particulate air, $\mathrm{HLLW}=$ high-level liquid waste, $\mathrm{ILW}=$ intermediate-level waste, $\mathrm{Na}=$ sodium, $\mathrm{NO}_{\mathrm{x}}=$ nitrogen oxides, $\mathrm{O}_{2}=$ oxygen, $\mathrm{Pu}=$ plutonium, $\mathrm{Ru}=$ ruthenium, $\mathrm{U}=$ uranium, and VOG $=$ vessel off-gas.

Source: Adapted from Ayer et al. (1988). 
TABLE C.2 Summary of Fire and Explosion Sources

\section{Potential Fire Sources}

Fire Category

General

Organic solvent

Hydrogen

Electrical

Sodium

Pyrophoric metal

Cellulose

\section{Source}

Vehicle fuel, welding, poor housekeeping.

Solvent separation columns, solvent recovery tanks, piping leaks.

Radiolysis of process solution.

Source of fire spread, loss of services.

Liquid sodium spills.

$\mathrm{U}, \mathrm{Pu}$ metal production, scrap recovery, loss of inert atmosphere.

Spontaneous combustion of cellulose wipes and nitric acid.

Potential Chemical Processing Explosion Sources
Source

$$
\mathrm{H}_{2} \text { explosion }
$$

Solvent or red oil explosion

Ion-exchange resin

Unstable compounds

Fire followed by explosion.
Radiolysis, $\mathrm{Na}-\mathrm{H}_{2} \mathrm{O}$ reaction, fluoride-zirconium reaction in dissolver or in a reducing furnace.

Organics in evaporators, concentrators, denitrators.

Silver-nitrogen-halogen compounds, ammonium nitrate, mercury compounds.

Generic Materials with Explosion Potential

$\begin{array}{ll}\text { Powdered metals } & \text { Methane } \\ \text { Hydrogen } & \text { Ozone } \\ \text { Acetylene } & \text { Picric acid } \\ \text { Volatile organic liquids } & \text { Explosive gas mixtures } \\ \text { Nitrates } & \text { Fuels, natural gas } \\ \text { Peroxides } & \end{array}$

Source: Adapted from Elder et al. (1986). 


\section{TABLE C.3 Postulated Criticalities in Treatment, Storage, and Disposal Facilities ${ }^{\mathrm{a}}$}

\begin{tabular}{|c|c|c|}
\hline Accident & Conditions Leading to Occurrence & $\begin{array}{c}\text { Potential Consequences and } \\
\text { Considerations }\end{array}$ \\
\hline $\begin{array}{l}\text { Criticality in fuel } \\
\text { storage facility } \\
\text { associated with } \\
\text { reprocessing plant }\end{array}$ & $\begin{array}{l}\text { Distortion of fuel storage array; } \\
\text { improper storage; fuel assembly } \\
\text { dropped into fuel storage array; } \\
\text { fissile material on pool water filter. }\end{array}$ & $\begin{array}{l}\text { Damaged elements could release short- } \\
\text { lived noble gases and iodine; radiation } \\
\text { high locally but largely shielded by pool } \\
\text { water. }\end{array}$ \\
\hline $\begin{array}{l}\text { Inadequate poison in } \\
\text { dissolvent }\end{array}$ & $\begin{array}{l}\text { Chemical makeup error due to } \\
\text { incorrect chemical analysis, addition } \\
\text { of wrong chemical, or weak poison } \\
\text { concentration; failure to add poison } \\
\text { at correct volume ratio because of } \\
\text { plugging, pump failure, operator } \\
\text { error, valving error, or metering } \\
\text { malfunction. }\end{array}$ & $\begin{array}{l}\text { Criticality potential in dissolver (in } \\
\text { conjunction with undetected plugging of } \\
\text { liquid or solids); digestor (in conjunction } \\
\text { with undetected accumulations of solids } \\
\text { or with over-concentrated solution); and } \\
\text { feed adjustment, accountability, surge, } \\
\text { and codecontamination feed tanks. }\end{array}$ \\
\hline $\begin{array}{l}\text { Criticality in } \\
\text { mechanical } \\
\text { processing and feed } \\
\text { preparation } \\
\text { operations }\end{array}$ & $\begin{array}{l}\text { Inadequate poison in dissolvent; } \\
\text { overconcentration of solution in } \\
\text { digester or feed adjustment, followed } \\
\text { by precipitation; accumulation of } \\
\text { fissile residue in digester or in solids } \\
\text { recycle tank; voloxidizer flooding } \\
\text { with water; caustic addition to feed; } \\
\text { dissolver blockage in addition to loss } \\
\text { of poison; accumulation of chopped } \\
\text { fuel on undetected stuck-shut } \\
\text { voloxidizer and dissolver. }\end{array}$ & $\begin{array}{l}\text { Criticality potential in cited tanks; } \\
\text { probable release of airborne activity, } \\
\text { including noble gases and iodine to cell } \\
\text { atmosphere and off-gas system; possible } \\
\text { severe equipment damage; high } \\
\text { radiation levels in cells; mass and energy } \\
\text { probably contained in cell; energy release } \\
11.0 \mathrm{E}+18 \text { fissions ( } 3.2 \mathrm{E}+4 \mathrm{~J}) \text {. }\end{array}$ \\
\hline $\begin{array}{l}\text { Criticality in solvent } \\
\text { extraction operations }\end{array}$ & $\begin{array}{l}\text { Excessive fissiles in HAW centrifuge } \\
\text { bowl; fissile material in unintended } \\
\text { location; damage to equipment; } \\
\text { plutonium reflux in first, second, or } \\
\text { plutonium purification cycle; } \\
\text { plutonium precipitation; fissile } \\
\text { uranium reflux; fissile material in } \\
\text { solvent tank. }\end{array}$ & $\begin{array}{l}\text { High local radiation and releases of } \\
\text { gaseous fission products to cell or to } \\
\text { VOG. }\end{array}$ \\
\hline $\begin{array}{l}\text { Criticality in product- } \\
\text { conversion operations }\end{array}$ & $\begin{array}{l}\text { Transfer errors in solvent extraction } \\
\text { or in product storage systems; } \\
\text { overbatched peroxide precipitator; } \\
\text { fissile material in } \mathrm{UO}_{3} \text { conversion } \\
\text { systems; no denaturant } \mathrm{U}-235 \text { in } \\
\text { feed to mixed-oxide system. }\end{array}$ & $\begin{array}{l}\text { High local radiation and release of } \\
\text { gaseous fission products to cell or VOG } \\
\text { system; damage to equipment. }\end{array}$ \\
\hline
\end{tabular}

a Abbreviations: $\mathrm{HAW}=$ high-level aqueous waste and $\mathrm{UO}_{3}=$ uranium trioxide.

Source: Adapted from Ayer et al. (1988). 
TABLE C.4 Summary of Criticality Accident Fission Yields

\begin{tabular}{|c|c|c|}
\hline System & $\begin{array}{l}\text { Initial Burst Yield } \\
\text { (fissions) }\end{array}$ & $\begin{array}{l}\text { Total Yield } \\
\text { (fissions) }\end{array}$ \\
\hline Solutions under $100 \mathrm{gal}$ & $1.0 \mathrm{E}+17$ & $3.0 \mathrm{E}+18$ \\
\hline Solutions over 100 gal & $1.0 \mathrm{E}+18$ & $3.0 \mathrm{E}+19$ \\
\hline Liquid powder ${ }^{\mathbf{a}}$ & $3.0 \mathrm{E}+20$ & $3.0 \mathrm{E}+20$ \\
\hline Liquid/metal pieces ${ }^{b}$ & $3.0 \mathrm{E}+18$ & $1.0 \mathrm{E}+19$ \\
\hline Solid uranium & $3.0 \mathrm{E}+19$ & $3.0 \mathrm{E}+19$ \\
\hline Solid plutonium & $1.0 \mathrm{E}+18$ & $1.0 \mathrm{E}+18$ \\
\hline $\begin{array}{l}\text { Large storage arrays }{ }^{c} \\
\text { (below prompt critical) }\end{array}$ & None & $1.0 \mathrm{E}+19$ \\
\hline $\begin{array}{l}\text { Large storage arrays }{ }^{c} \\
\text { (above prompt critical) }\end{array}$ & $3.0 \mathrm{E}+22$ & $3.0 \mathrm{E}+22$ \\
\hline
\end{tabular}

a A system where agitation of a powder layer could result in progressively higher reactivity insertion.

b A system of small pieces of fissile metal.

c Large storage arrays in which many pieces of fissile material are present and could conceivably come together.

Source: Adapted from Elder et al. (1986).

damage was done to the incinerator itself, and no injuries or releases resulted. The particular unit was shut down, and the rest of the plant was back up and operating under normal conditions within one week.

CWM Chemical Systems Inc., Chicago Incinerator (previously SCA) Chicago, Illinois. This explosion occurred in February 1991 in a drum inserted in the rotary kiln incinerator. The drum contained a lab pack that the company failed to identify, but which was found to be an explosive in its pure form called tetra-zole. The explosion caused a bulge in the kiln, and one of the plates on the back of the kiln popped off as a result of the pressure buildup. No one was hurt as a result of the explosion; however, a site worker complained about slight dizziness. There was no indication of any toxic releases into the neighboring areas. The regional EPA required the plant to replace several parts of the unit before restarting operations. Additional fire prevention and safety equipment were also required. 
TABLE C.5 Summary of Fires, Explosions, and Incidents of Drum Overpressurization $^{\mathbf{a}}$

\begin{tabular}{|c|c|c|c|c|}
\hline Date & Site $^{b}$ & Event & Probable Cause & Current Regulation $^{c}$ \\
\hline $6 / 1 / 70$ & INEL & $\begin{array}{l}\text { Burial ground fire in } \\
55 \text {-gal drum }\end{array}$ & Pyrophories & Restriction on pyrophorics \\
\hline $12 / 3 / 76$ & ANL-E & $\begin{array}{l}\text { Explosion of 55-gal } \\
\text { drum }\end{array}$ & Flammable VOCs & $\begin{array}{l}\text { Vents, restriction on flammable } \\
\text { VOCs }\end{array}$ \\
\hline $8 / 17 / 78$ & Hanford & $\begin{array}{l}\text { Distortion of 55-gal } \\
\text { drums }\end{array}$ & $\begin{array}{l}\text { Reaction between } \\
\text { nitric acid and } \\
\text { organic compounds }\end{array}$ & $\begin{array}{l}\text { Vents, restriction on free liquids } \\
\text { and incompatible chemicals }\end{array}$ \\
\hline $3 / 13 / 82$ & Hanford & $\begin{array}{l}\text { Uranium-concrete } \\
\text { billet fire }\end{array}$ & Pyrophorics & Restrictions on pyrophorics \\
\hline $6 / 30 / 83$ & LLNL & $\begin{array}{l}\text { Fire in bags of dry } \\
\text { waste }\end{array}$ & $\begin{array}{l}\text { Pyrophorics, } \\
\text { flammable VOCs }\end{array}$ & $\begin{array}{l}\text { Restrictions on pyrophorics, } \\
\text { flammable VOCs }\end{array}$ \\
\hline $4 / 20 / 84$ & INEL & $\begin{array}{l}\text { Fire in a radioactive } \\
\text { waste container }\end{array}$ & $\begin{array}{l}\text { Spontaneous } \\
\text { combustion of nitric } \\
\text { acid }\end{array}$ & $\begin{array}{l}\text { Restrictions on corrosives, } \\
\text { chemical incompatibility }\end{array}$ \\
\hline $7 / 20 / 85$ & $\begin{array}{l}\text { ORNL at } \\
\text { Y-12 }\end{array}$ & $\begin{array}{l}\text { Fire involving } \\
\text { thorium in a } \\
\text { scrapped glove box }\end{array}$ & Pyrophorics & Restrictions on pyrophorics \\
\hline 9/19/85 & RFETS & $\begin{array}{l}\text { Pressurization of } \\
\text { containers and } \\
\text { release of plutonium }\end{array}$ & $\begin{array}{l}\text { Plutonium fines, } \\
\text { calcium, moisture }\end{array}$ & $\begin{array}{l}\text { Restriction on chemical } \\
\text { incompatibility, vents }\end{array}$ \\
\hline
\end{tabular}

a Source: adapted from M. Silva (1992).

b Abbreviations: ANL-E = Argonne National Laboratory-East, INEL = Idaho National Engineering Laboratory, LLNL = Lawrence Livermore National Laboratory, ORNL = Oak Ridge National Laboratory, RFETS = Rocky Flats Environmental Technology Site, and VOC = volatile organic compound.

c Source: DOE (1991).

Thermalkem, Roebuck, South Carolina. This explosion occurred in July 1987 as a result of a $10 \%$ nitroglycerine/ $90 \%$ lactose material that had been incorrectly identified by the generator and was found to be an explosive. This material triggered two explosions within the incinerator and one partially outside the incinerator. No environmental releases were reported from the fires, although two employees complained of ringing of the ears. Following the incident, a more rigorous waste approval procedure was instituted.

Another explosion occurred in March 1991 in the tubes of the boiler operating on natural gas/fuel oil. The tubes in the boiler failed to operate, and steam was introduced into the flame. This moved the package boiler about $15 \mathrm{~m}(50 \mathrm{ft})$, resulting in extensive damage to the boiler and the boiler house and severance of the steam and fuel oil lines. The natural gas lines were immediately shut off, and no hazardous waste was involved in the incident. No one was hurt as a result, and a new boiler was in operation in three days. 
U.S. Department of Energy, Oak Ridge, Tennessee. In June 1989, the induced draft fan for the incinerator failed. The failure breached the fan housing, and debris was found as far away as $113 \mathrm{~m}(370 \mathrm{ft})$. Flying debris damaged the stack. There were no injuries and no detectable off-site release of toxic material as a result of the incident.

DOW Chemical Company, Midland, Michigan. In January 1992, a natural gas explosion resulted from blockage of a feed line to the incinerator. In the process of trying to clear the line, a drill bit broke off in the nozzle. The nozzle was removed improperly, and as a result, natural gas leaked out causing an explosion. This incident occurred during normal operations in a room at the front of the incinerator. One worker sustained first and second degree burns to the face and hands, while another worker complained of ringing in the ears. There is no evidence that any hazardous waste was released, and there was no natural resource damage. Following the incident, improvements were made in the gas sensing equipment, and steps to ensure adherence to proper procedures for unplugging feed lines were ensured.

TWI, Sauget, Illinois. Several explosions occurred at this facility. The first occurred when a large volume of ash accumulated and fell into the unit's quench tank, causing a steam explosion in the incinerator. No date was given for this incident.

The second explosion occurred in January 1991 when sodium azide, the explosive found in automobile air bags, was incinerated. The ash from this waste was placed in a dumpster; a few hours later, the ash exploded. No injuries or environmental impacts from these two incidents were reported.

A third explosion occurred in February 1991 as a result of a worker using a pole to dislodge molten slag that partly blocked the exit from an incinerator during operation. The slag fell into standing water below and caused a steam explosion that severely burned the worker. Vaporized hazardous waste was released.

Monsanto Company, Muscatine, Iowa. In July, 1992, the incinerator at the Monsanto facility was shut down while the facility's process unit was being repaired. When the incinerator was brought back on line, there was a loss of quench water flow that caused the temperature in the scrubber to rise to $108^{\circ} \mathrm{C}\left(2,000^{\circ} \mathrm{F}\right)$. Consequently, the unit's scrubber caught fire. However, only natural gas was present in the incinerator at the time of the incident; no hazardous waste was in the incinerator. As a result, there were no releases of hazardous waste to the environment and no injuries were reported. Since then, the facility has updated its controls to better identify losses of water pressure.

Aptus, Coffeyville, Kansas. This incident occurred in the fall of 1990 during normal operations. Waste with an exceedingly high British thermal unit (Btu) level was introduced to the incinerator. Gas accumulated in the electrostatic precipitator and was set off by a spark. The explosion was completely contained within the unit. The unit's air pollution control devices were damaged internally, and the unit was out of operation for about one week. No injuries or natural resources damage was reported. Since this incident, tighter controls of the waste stream have been instituted. 


\section{C.3 REFERENCES}

Ayer, J.E., et al., 1988, Nuclear Fuel Cycle Accident Analysis Handbook, NUREG-1320, U.S. Nuclear Regulatory Commission, Washington, D.C., May.

Elder, J., et al., 1986, A Guide to Radiological Accident Considerations for Siting and Design of DOE Nonreactor Nuclear Facilities, LA-10294-MS/UC-41, Los Alamos National Laboratory, Los Alamos, N.M.

Hlustick, D., 1994, personal communication from Hlustick (U.S. Environmental Protection Agency, Washington, D.C.) to C. Herzenberg (Argonne National Laboratory, Argonne, Ill.), April 14.

Silva, M., 1992, "An Assessment of the Flammability and Explosion Potential of Defense Transuranic Waste," Nuclear Safety 33(2).

U.S. Department of Energy, 1991, Position Paper on Flammability Concerns Associated with TRU Waste Destined for WIPP, DOE/WIPP-91-018, Washington, D.C. 


\section{APPENDIX D:}

\section{REFERENCE DATA ON RESPIRABLE AIRBORNE RELEASE FRACTIONS} AND LEAK PATH FACTORS 


\section{CONTENTS}

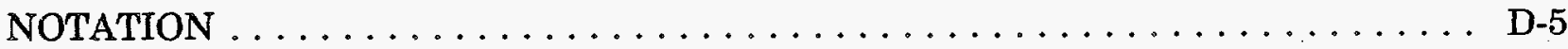

D.1 Respirable Airborne Release Fraction $\ldots \ldots \ldots \ldots \ldots \ldots \ldots \ldots \ldots \ldots$. . . . . . .

D.1.1 Background . . . . . . . . . . . . . . . . . . . . D D

D.1.2 Airborne Release Fractions, Respirable Fractions, and Respirable Airborne Release Fractions . . . . . . . . . . D D

D.2 Leak Path Factors $\ldots \ldots \ldots \ldots \ldots \ldots \ldots \ldots \ldots \ldots \ldots \ldots$. . . . . . . . . . . . . . . . . .

D.2.1 Background . . . . . . . . . . . . . . . . . . . . . D-48

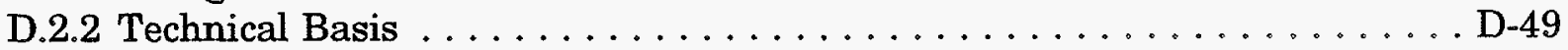

D.2.3 Application to WM PEIS . . . . . . . . . . . . . . . D-50

D.3 Mapping of WM PEIS Treatability Categories with Physical Form

Categories for Accident Analysis . . . . . . . . . . . . . . . . D-50

D.4 References $\ldots \ldots \ldots \ldots \ldots \ldots \ldots \ldots \ldots \ldots \ldots \ldots \ldots \ldots \ldots$

\section{TABLES}

D.1 Summary of Release Fraction Parameters Abstracted from

Elder et al. (1986) . . . . . . . . . . . . . . . . . . . . . D-52

D.2 WM PEIS Waste RARFs: Physical Type or Subcategory versus Stress . . . . . D-53

D.3 WM PEIS Waste RARFs for LLW, LLMW, and TRUW Storage and Handling . . . . . . . . . . . . . . . . D-54

D.4 WM PEIS Waste RARFs for LLW Processing by Incineration . . . . . . . . . D-57

D.5 WM PEIS Waste RARFs for HLW Processing and Storage . . . . . . . . . D-60

D.6 Threshold Values of Differential Pressure Required to Structurally

Damage Standard HEPA Filter

D.7 Effects of Environmental Filter Parameters on Aerosol Penetration through HEPA Filters . . . . . . . . . . . . . . . . . . D D-64

D.8 Summary of Reduction and Removal Factors Abstracted from Elder et al. (1986) . . . . . . . . . . . . . . . . . . . . . . . . . D-65

D.9 Mapping of WM PEIS Treatability Categories for LLW with Accident Analysis Physical Forms 


\section{TABLES (Cont.)}

D.10 Mapping of WM PEIS Treatability Categories for TRUW with Accident Analysis Physical Forms . . . . . . . . . . . . . . . . . . . . D-70

D.11 Mapping of WM PEIS Treatability Categories for HLW with Accident Analysis Physical Forms D-73 


\section{NOTATION}

The following is a list of the acronyms, initialisms, and abbreviations (including elements and compounds and units of measure) that appear in this appendix.

\section{ACRONYMS, INITIALISMS, AND ABBREVIATIONS}

AED aerodynamic equivalent diameter

ARF airborne release fraction

DAW dry active waste

DOE U.S. Department of Energy

EM Environmental Management

HEPA high-efficiency particulate air (filter)

HLW high-level waste

LLMW low-level mixed waste

LLW low-level waste

LPF leak path factor

NRC U.S. Nuclear Regulatory Commission

PEIS Programmatic Environmental Impact Statement

RARF respirable airborne release fraction

$\mathrm{RF}$ respirable fraction

SAIC Science Applications International Corp.

SNF spent nuclear fuel

SpG specific gravity

SRS Savannah River Site

TRUW transuranic waste

WM Waste Management

\section{ELEMENTS AND COMPOUNDS}

$\begin{array}{ll}\mathrm{Ag} & \text { silver } \\ \mathrm{CaO} & \text { calcium oxide } \\ \mathrm{CH}_{3} \mathrm{I} & \text { methyl iodide } \\ \mathrm{CO}_{2} & \text { carbon dioxide } \\ \mathrm{Cs} & \text { cesium } \\ \mathrm{CsI} & \text { cesium iodide } \\ { }^{3} \mathrm{H} & \text { tritium } \\ \mathrm{HF} & \text { hydrogen fluoride } \\ { }^{3} \mathrm{H}_{2} \mathrm{O} & \text { tritiated water } \\ \mathrm{HNO}_{3} & \text { nitric acid } \\ \mathrm{I}_{2} & \text { elemental iodine } \\ \mathrm{Kr} & \text { krypton } \\ \mathrm{Pu} & \text { plutonium } \\ \mathrm{PuF} & \text { plutonium fluoride } \\ \mathrm{Rb} & \text { rubidium } \\ \mathrm{Ru} & \text { ruthenium }\end{array}$


$\mathrm{RuO}_{4}$ ruthenium tetroxide

$\mathrm{Se}$ selenium

Tc technetium

$\mathrm{Te}$ tellurium

$\mathrm{TiO}_{2}$ titanium dioxide

TNT trinitrotoluene

U uranium

$\mathrm{UO}_{2}$ uranium dioxide

\section{UNITS OF MEASURE}

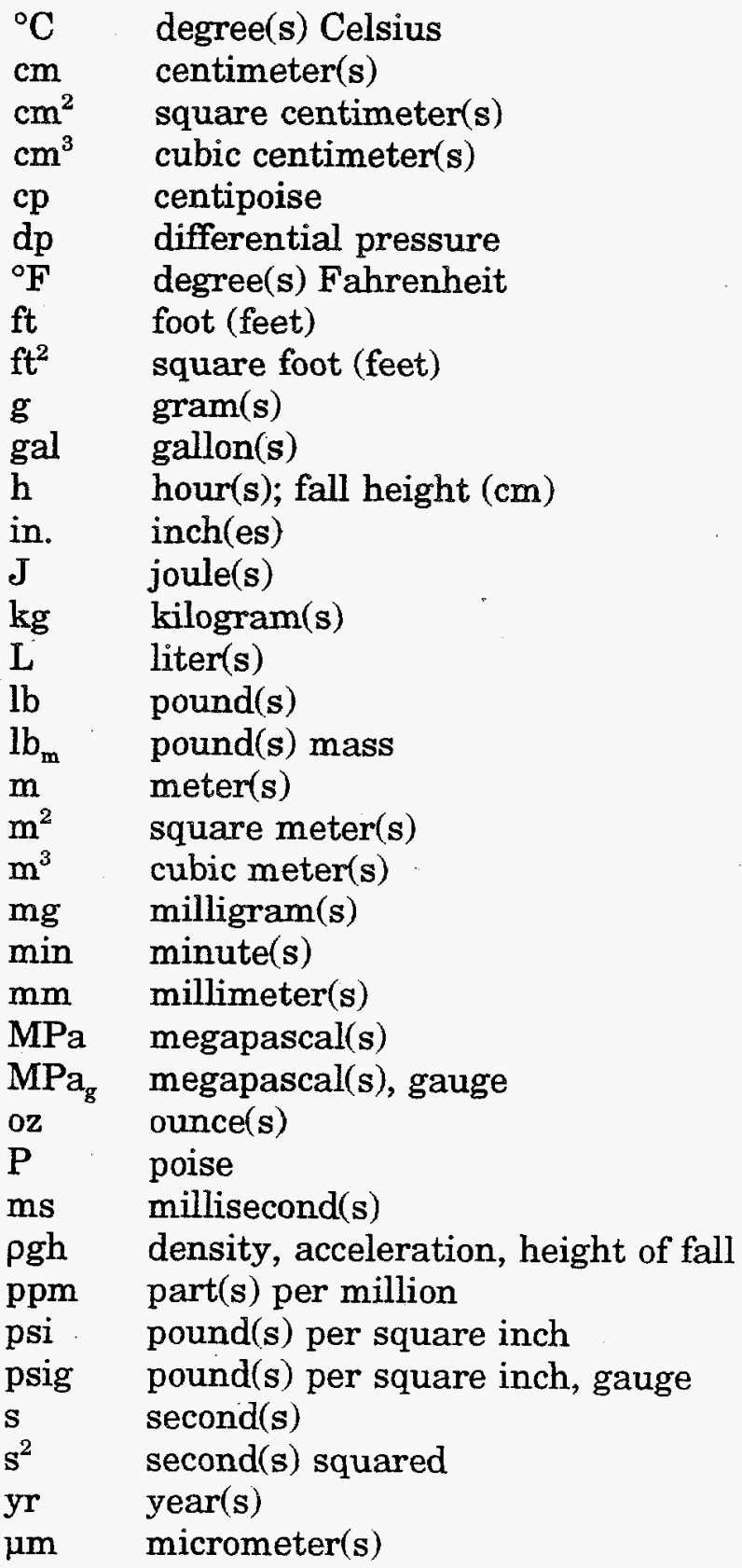




\section{APPENDIX D:}

\section{REFERENCE DATA ON RESPIRABLE AIRBORNE RELEASE FRACTIONS AND LEAK PATH FACTORS}

Respirable airborne release fractions (RARFs) and leak path factors (LPFs) are two of the four components used to estimate the source term from inadvertent events during handling, storage, and processing of waste. The RARF and LPF represent the fraction of the materials of concern (in this analysis, radionuclides) that enters the ambient environment from that event. The other components (material at risk and damage ratios) are covered in Section 2.4 of this report. The RARF is a combination of the airborne release fraction (ARF - the fraction of the material of concern made airborne at the point of origin) and the respirable fraction ( $R F$ - the fraction of the $A R F$ that is in the respirable size range ${ }^{1}$ ). The LPF is the fraction of the released material that will travel from the point of origin to the equipment-atmosphere interface for the facility or enclosure or container and be released to the ambient environment; the LPF includes the reduction of the airborme materials by functional air-treatment attenuation devices (e.g., filters) and by other factors (i.e., deposition within the ventilation ducts) for the physical or chemical form. This appendix presents the technical basis for the RARFs and LPFs used in these analyses.

\section{D.1 RESPIRABLE AIRBORNE RELEASE FRACTION}

\section{D.1.1 Background}

In prior years, compilations of release fractions (Elder et al. 1986; Walker 1987) have been documented for varying purposes. Walker's compilation (1987) presents the release fractions derived from experimental studies for both fuel-cycle and reactor accident evaluations available at that time. Elder et al. (1986) presented very conservative estimates of release fractions for evaluating events of unknown magnitude that could involve the entire inventory of the facility; these estimates were used for evaluating the proposed facility's conformance to siting criteria. The release fractions derived from Elder et al. (1986) are shown in Table D.1. (To aid the reader, all tables are presented after the text of this appendix.)

More recently, large numbers of experiments have been performed to ascertain the release fractions from both industrial and reactor accident stresses. The most recent experimental data on ARFs and RFs for accident stress for nuclear materials can be found

1 The respirable size range is commonly assumed to be that fraction of particulate material that has an aerodynamic equivalent diameter (AED) of $10 \mu \mathrm{m}$ or less. The AED is the size of a sphere of material with a density of $1 \mathrm{~g} / \mathrm{cm}^{3}$ that shows the same aerodynamic behavior (terminal velocity of the sphere) as the particle. All materials in the gaseous phase are assumed to be transportable and respirable; a $\mathrm{RF}$ of 1.0 is assumed for the purposes of these analyses. Some materials in the gaseous phase (i.e., vapors) may condense when they encounter varying physical and chemical conditions. 
in a U.S. Department of Energy (DOE) report (DOE [1994]). These data were used as the primary basis for the RARFs used in these analyses. Other recent data and estimations of reactor or spent nuclear fuel (SNF) accident release fractions (Restrepo 1992; Teleyarkhan 1992; Soffer 1993) can also be found in DOE (1994).

The values presented in this appendix should be applied cautiously. The characteristics of the materials made airborne are the result of interactions between two complex physicochemical processes: the initiating event and the responses of the materials involved. Both the stress and the level of stress for the specific scenario must be ascertained to ensure that the appropriate RARF is selected. The experimental bases only cover a range of parameters and may not cover the level of the specific stress estimated for the postulated release. For generic systems, the bounding event for the generic process or facility situation is chosen by using limiting factors. To generate a reasonable bounding source term, factors describing the various parameters are chosen that reflect the lack of definition for these attributes; the less precise the definition, the greater the conservatism.

\section{D.1.2 Airborne Release Fractions, Respirable Fractions, and Respirable Airborne Release Fractions}

Most radioactive materials are separated from the ambient environment by a barrier (e.g., a structure; enclosures such as glove boxes or hot cells; equipment such as tanks or piping; containers ranging from large casks to sheet-metal cans, including 208-L [55-gal] sheet-metal drums). Often the materials released are confined by many barriers, such as a building or gaseous-effluent treatment system, including filtration devices for specific materials (e.g., high-efficiency particulate air [HEPA] filters; fibrous filters of various materials, such as bag or cartridge-type filters; impregnated activated charcoal or silver-substituted zeolite for iodine). Most of the materials are at rest or, if in process, are controlled to prevent release.

The data and assumptions for the response of the various waste form subcategories to the stresses postulated are shown in Table D.2 and discussed in the following sections.

\section{D.1.2.1 Technical Basis}

D.1.2.1.1 Noncondensable Gases. No direct data were found on the airborne release of noncondensable gases on loss of containment. On the basis of the established physical behavior of the material, the assumption is that all noncondensable gases and all materials in the gaseous state are made airborne on loss of containment. Noncondensable gases produced by nuclear fissions in a nonporous matrix (SNF and production targets) are covered under the appropriate matrices. The RARF is derived on the assumption that all radionuclides in the form of noncondensable gases are released on loss of containment. 
D.1.2.1.2 Vapors. On generation, vapors in the gaseous state are assumed to behave as a gas and become airborne. Materials volatilized by elevated temperatures (e.g., water vapor or metal fume) may condense into particulate materials on cooling. The particle size of the condensed phase is a function of the cooling conditions, among other factors (local concentration, air velocity, etc.). Furthermore, chemically active vapors (e.g., iodine) may react with other materials encountered (in the air or surfaces) or attach to preexisting airborne particles.

The RARF was derived on the basis of the following assumptions:

- For all tritiated water $\left({ }^{3} \mathrm{H}_{2} \mathrm{O}\right)$ or tritiated hydrides, all material converted to the vapor form is considered released on loss of containment. Fires and deflagrations constitute the primary concern because these situations may possess the requisite conditions to breach containment (pressure) and to convert the water or hydride to vapor (heat).

- All iodine present is converted to the vapor form in the presence of oxidizing, acid conditions. The primary concern is with fires that involve iodine in nitric acid solutions that may pressurize containment and convert the iodine (I) in solution to molecular iodine or gaseous forms of iodine compounds.

- For ruthenium ( $\mathrm{Ru}$ ), strong oxidizing conditions are required, and not all of the $\mathrm{Ru}$ converts to ruthenium tetroxide $\left(\mathrm{RuO}_{4}\right)$, which is the volatile compound. Under fire conditions (fires involving $\mathrm{Ru}$ compounds in a strong nitric acid solution), some fraction may be converted. Conservative estimates of $1 \mathrm{E}-02$ for a small fire and $1 \mathrm{E}-01$ for a large fire are assumed.

D.1.2.1.3 Liquids. Three types of liquids are commonly encountered in the storage, handling, and processing of Environmental Management (EM) waste. The three materials are (1) aqueous solutions and slurries, (2) organic liquids and slurries, and (3) viscous liquids such as molten high-level waste (HLW). The responses of the first two categories to the various postulated stresses are discussed subsequently. Two subcategories are described for organic combustible liquids (organic combustible solutions and slurries), and three subcategories are covered for aqueous liquids (aqueous solutions, aqueous slurries, and superheated solutions). Viscous liquids will be covered later, along with vitrified HLW.

Organic, Combustible Liquids Organic, Combustible Solutions. Only data on the airborne release of radionuclides during the combustion of organic combustible liquids 
were found. Other RARF values were inferred from the behavior of aqueous liquid in response to the following stresses:

- Free-Fall Spill. On the basis of the configuration of equipment in most facilities involving waste in solution form, the assumption was that a free-fall of $3 \mathrm{~m}(10 \mathrm{ft})$ is bounding. The bounding value for the ARF was $2 \mathrm{E}-04$, with a $R F$ of 0.7 , resulting in a RARF of $1 \mathrm{E}-04$. The value was rounded upward to $2 \mathrm{E}-04$ for conservatism.

- Crush-Impact. No direct experimental data exist on the fragmentation and suspension of an organic combustible solution due to the impact of debris or foreign objects. The assumption was that the RARF will be bounded by the RARF for the free-fall spill discussed previously; a RARF of $2 \mathrm{E}-04$ was assumed.

- Overpressurization or Breach by Mechanical Action. This subcategory represents the breach of a container by mechanical action; only minor pressurization incidental to the breaching process was assumed. The breach was assumed to occur at a point low on the sidewall to allow most of the liquid to be sprayed from the breach by the pressure of the water column above the liquid. Data for the size distribution of spray generated by commercial spray nozzles designed to generate a fine spray with an orifice of $3.25 \mathrm{~mm}(0.128$-in.) at a pressure of $1.38 \mathrm{MPa}$ (200 psig) resulted in a RF of $1 \mathrm{E}-04$. The value certainly bounds most punctures and breaches due to mechanical action. Very long, narrow (on the order of a $0.1-\mathrm{mm}$ span) punctures at high pressure may generate a larger fraction of particles in the respirable size range.

- Small Fire. The assumption was that a small isolated pool of organic combustible solution is ignited and burns to a small residual puddle of viscous liquid that would not allow the combustion process to go to completion. The combustion does not generate high turbulence over the burning liquid. All ${ }^{3} \mathrm{H}_{2} \mathrm{O}$ dissolved in the liquid and the hydride compounds are released during burning. The ARF for nonvolatile solutes during quiescent burning was $1 \mathrm{E}-02$, with no measured RF. A conservative value of 1.0 was assumed for the RF. The resultant RARF was $1 \mathrm{E}-02$.

- Large Fire. The assumption was that a large pool of organic combustible solution is ignited and burns. Because of the physical configuration and the presence of metal (a heat-conducting material), the fire is vigorous, and surface turbulence is high. The liquid is all consumed (burns to dryness). All of the tritiated materials are released, as stated previously. The ARF for nonvolatile solutes for a vigorous fire that burns to dryness was $1 E-01$, with no measured RF. A conservative $R F$ of 1.0 was assumed. The resultant RARF was $1 E-01$. 
- Explosive Release: Blast Effects. The assumption was that a volume of flammable gas mixture deflagrates above the organic, combustible liquid and both disturbs the surface and ignites the liquid. The RARF determined for a large fire (1E-01) was selected for this subcategory.

- Explosive Release: Shock Effects. The assumption was that a detonation (commonly the only source of significant shock effects) occurs in or on the surface of the organic combustible solution. The Steindler and Seefeldt correlation given in DOE (1994) is $1 \mathrm{~g}$ of liquid mass per gram of trinitrotoluene (TNT) equivalence calculated for the detonation. Detonation occurs in microseconds to milliseconds and, because of the rapidity of the reaction, is not assumed to ignite the liquid. The mass of airborne liquid is not the mass of the material of concern released. To determine the mass of the material of concern made airborne, the mass of liquid airborne must be multiplied by the concentration of the material of concern in the liquid (with the assumption that no material of concern is converted into a volatile form).

- Venting of the Free Volume over the Liquid at Pressures Ranging from Less Than $0.345 \mathrm{MPa}_{\mathrm{g}}(50 \mathrm{psig})$ to $3.45 \mathrm{MPa}_{\mathrm{g}}(500 \mathrm{psig})$. The assumption was that the products of some conditions (e.g., a leak of high-pressure gas into the container or increased vapor pressure due to the heating of the liquid to less than the temperature needed to form a "flashing spray") in a closed vessel holding the organic combustible solutions breach the vessel at a point above the liquid level. The rapid depressurization causes the rapid release of the gas dissolved in the liquid, resulting in a condition similar to boiling of the liquid (bubbles breaking at the surface). The ARF for the depressurization of liquid was $2 \mathrm{E}-03$, with a $\mathrm{RF}$ of 0.3 , resulting in a RARF of $6 \mathrm{E}-04$. This RARF does not cover the churn-turbulent or chaotic regimes of bubbling.

Organic-Combustible Slurries. This subcategory of waste is assumed to be composed of insoluble nonreactive particles in an organic combustible liquid. No experimental data on the airborne release for the impact of the various stresses covered here were found. The response of the organic combustible slurries is assumed to be similar to that of aqueous slurries under accident stress, and the data for that subcategory were applied. The assumptions for the stresses were as follows:

- Free-Fall Spill. On the basis of the configuration of equipment in most facilities involving waste in this form, the assumption was that a freefall of $3 \mathrm{~m}(10 \mathrm{ft})$ or less is bounding. The measured ARF for the free-fall spill of aqueous slurries of $3 \mathrm{~m}$ ( $10 \mathrm{ft}$ ) or less was $5 \mathrm{E}-05$, with a $R F$ of 0.8 , resulting in a RARF of $4 \mathrm{E}-05$. 
- Crush-Impact. The impact of a foreign object is bounded by the free-fall of the slurry; the same RARF of $4 \mathrm{E}-05$ was applied.

- Overpressurization/Breach by Mechanical Action. The assumption was that organic combustible slurries behave like the organic combustible solutions described previously when vented from a breach under the liquid level at a point near the bottom of the sidewall of the container. The RARF of 1E-04 was applied.

- Small Fires. The maximum ARF for nonreactive particles during the burning of a cellulosic substrate was $1 \mathrm{E}-02$, with no measured RF. A lesser value was measured during the heating of a nonreactive powder (6E-05) and reactive powders ( $1 \mathrm{E}-05$ for plutonium oxalate and $1 \mathrm{E}-06$ for plutonium fluoride $\left.\left[\mathrm{PuF}_{4}\right]\right)$. Because of the lack of knowledge of the specific compounds comprising the insoluble particles that could be found in the slurry, a bounding RARF of 1E-02 was assigned.

- Large Fire. The size of the fire may have an impact on the burning rate and characteristics of the fires, but the behavior of the insoluble particles that tend to collect at the bottom of the liquid would not be seriously different from that proposed previously. Because of the conservative nature of the assumptions for the small fire, the same RARF (1E-02) was assigned for a large fire.

- Explosive Release: Blast Effects. Deflagration generates surface turbulence, entrains a small amount of liquid ( $<7 \mathrm{E}-05)$, and ignites the airborne material, resulting in conditions similar to those encountered in a large fire that burns to dryness. The RARF selected for the large fire (1E-01) was assigned for this subcategory.

- Explosive Reaction: Shock Effects. A detonation in or on the surface of the slurry would result in the same response as described previously for the organic combustible solution. The RARF assigned was $1 \mathrm{~g}$ of slurry airborne per gram of TNT equivalence calculated for the detonation. To determine the mass of the insoluble particles made airborne, multiply the mass of the slurry by the concentration of the insoluble particles in the slurry. The assumption was that the reaction is too rapid to ignite the organic combustible liquid.

- Venting of the Free Volume over the Liquid at Pressures Ranging from Less Than $0.345 \mathrm{MPa}_{\mathrm{g}}(50 \mathrm{psig})$ to $3.45 \mathrm{MPa}_{\mathrm{g}}$ (500 psig). Insoluble particles are uniformly mixed in the organic slurry by the generation of bubbles in the liquid. The slurry also behaves like the organic combustible liquid described previously for this stress. A RARF of 6E-04 was assigned. 
Aqueous Liquids, Aqueous Solutions. This subcategory encompasses solutes soluble in water. For RARFs that represent a fraction of the material aerosolized, the fraction of the material of concern aerosolized would be the same, assuming a uniform concentration. Experimental data for most stresses were available and were applied. The assumptions for the stresses were as follows:

- Free-Fall Spill. On the basis of (1) the configuration of equipment in most facilities involving this form of waste, (2) the fact that the liquid must be released from the bottom or from the bottom of the sidewall of a vessel for essentially all of the liquid to leak from a container, and (3) the angle that the container must assume to pour the liquid from the top of a tilted vessel, the assumption was that a free-fall of $3 \mathrm{~m}(10 \mathrm{ft})$ or less is bounding. The measured ARF for the free-fall spill of an aqueous solution was $2 \mathrm{E}-04$, with a RF of 0.7 , resulting in a RARF of 1E-04. The value was rounded upward for conservatism, and a RARF of $2 \mathrm{E}-04$ was assigned.

- Crush-Impact. As with the previous subcategories, the assumption was that the impact or crushing by a foreign body results in behavior similar to but bounded by the free-fall of the aqueous solution. A RARF of 2E-04 was assigned.

- Overpressurization/Breach by Mechanical Action. This scenario involves low container pressures because the venting is by mecnanical actions such as puncture. As with the organic combustible liquids, spray formation was presumed to be the mechanism for aerosolization of the liquid. The RARF assigned was 1E-04.

- Small Fire. A small fire heats the aqueous solution, resulting in boiling of the liquid (simply heating the liquid with no bubble breakup at the surface results in much less aerosolization: ARF of 3E-05). The measured ARF for boiling was $2 \mathrm{E}-03$, with no measured RF. A conservative $R F$ of 1.0 was assumed, with a resultant RARF of $2 \mathrm{E}-03$. This value is not applicable to the churn-turbulent or chaotic regimes of liquid boiling that may result in a greater fraction breaking away from the liquid surface (and possibly eructation - the violent ejection of liquid from a container) but does not necessarily form a greater RF.

- Large Fire. A large fire results in a greater release rate but does not result in a larger RARF. A RARF of $2 \mathrm{E}-03$ was assigned.

- Explosive Release: Blast Effects. Aerosolization is by the impact of shear stress upon the surface (accelerated airflow across the liquid surface resulting in surface turbulence and droplet formation). The maximum measured airborne release rate of $9 \mathrm{E}-05 / \mathrm{h}$ was rounded to $1 E-04$, although assuming that the passage of the pressure impulse 
resulting from a deflagration (completed in milliseconds to seconds) over the surface of the aqueous solution requires one hour is highly conservative.

- Explosive Release: Shock Effects. The conservative interpretation of the correlation for detonation in or on the surface of liquids and metals was assigned ( $1 \mathrm{~g}$ of droplets in the respirable size range for each gram of TNT equivalence calculated). The fraction of the solute aerosolized depends on its concentration in the liquid.

- Venting of the Free Volume above the Liquid at Pressures Ranging from Less Than $0.345 M P a_{g}(50 \mathrm{psig})$ to $3.45 M P a_{g}$ (500 psig). The process described previously for this stress for organic combustible solutions is also postulated here. The bounding measured ARF was $2 \mathrm{E}-03$, with a RF of 0.3 . The RARF was $6 \mathrm{E}-04$.

Aqueous Slurries. The only experimental data for this subcategory were for free-fall spill. All other responses were assumed to be the same as for aqueous solutions. For a release value given as a fraction of the mass, the mass of the material of concern was determined by multiplying the mass released by the stress times the concentration of the material of concern in the water. This procedure assumes a uniform concentration of insoluble particles in the water. This assumption can be questionable for slurries under many situations where the release occurs primarily from the upper surface of a volume. Nonetheless, for these analyses, where precise definitions were not possible, assuming uniform concentration is conservative inasmuch as the particles tend to settle to the lower levels of the slurry in most cases. The assumptions for the stresses were as follows:

- Free-Fall Spills. The bounding ARF was 5E-05, with a RF of 0.8, resulting in a RARF of $4 \mathrm{E}-05$.

- Crush-Impact. The impact of or crushing by a foreign body was bounded by the free-fall aerosolization, and a RARF of $4 \mathrm{E}-5$ was assigned.

- Overpressurization/Breach by Mechanical Action. The same assumptions applied to aqueous solutions apply here, and the RARF of 1E-04 for sprays was assigned.

- Small Fire. Although some bases exist for applying the nonboiling aerosolization RARF (3E-05) in these situations, the temperature or boiling of the aqueous liquid depends on many factors, such as the relative size of the fire, the volume of liquid, the distance from the flame to the liquid, and the heat transfer through the vessel wall. On these bases, the assumption was that the boiling RARF of $2 \mathrm{E}-03$ was applicable. 
- Large Fire. The RARF of 2E-03 for boiling aqueous liquids was assigned for the stress.

- Explosive Release: Blast Effects. As for other liquids, the aerosolization due to the shear stress induced on the liquid surface by the accelerated air velocity generated by the deflagration was assumed to apply here. The RARF for the stress (1E-04) was assigned to this stress.

- Explosive Release: Shock Effects. As for other liquids, the very conservative RARF of $1 \mathrm{~g}$ of respirable droplets for each gram of TNT equivalence calculated for the detonation was applied. The mass of the solute must be calculated.

- Venting of the Free Volume over the Liquid at Pressures Ranging from Less than $0.345 \mathrm{MPa}_{\mathrm{g}}$ (50 psig) to $3.45 \mathrm{MPa}_{\mathrm{g}}$ (500 psig). The RARF (6E-04) for aqueous solutions was assigned for this stress.

Superheated Liquids. For these analyses, it was assumed that any aqueous liquid heated to a superheat temperature of $50^{\circ} \mathrm{C}\left(122^{\circ} \mathrm{F}\right)$ and greater will form a flashing spray (the bulk formation of vapor internally in the liquid results in a high degree of fragmentation and is dependent on the superheat temperature). For aqueous liquids with a superheat of $50-100^{\circ} \mathrm{C}\left(122-212^{\circ} \mathrm{F}\right)$, the maximum measured $\mathrm{ARF}$ was $9 \mathrm{E}-02$, with a $\mathrm{RF}$ of 0.7 , resulting in a RARF of 7E-02. Because of the level of uncertainty in the amount of size reduction of the droplets that may result from the evaporation of water (the temperature of the water is near $100^{\circ} \mathrm{C}\left[212^{\circ} \mathrm{F}\right]$ ), subsequent to formation, a bounding RARF of $1 \mathrm{E}-01$ was assigned for this phenomenon. For aqueous liquids with a superheat greater than $100^{\circ} \mathrm{C}\left(212^{\circ} \mathrm{F}\right)$, the ARF can be estimated by

$$
A R F=0.33\left(M F_{v}\right)^{0.91},
$$

where $M F_{v}$ is the mole fraction of vapor formed by the depressurization.

The aerodynamic mass median diameter of the droplets is $21 \mu \mathrm{m}$, with a geometric standard deviation of 3.0 corrected for evaporation and settling, resulting in a RF of 0.3 for the conditions stated. To approximate the AED and to determine the RF, the density of the droplet is required. The final density would depend on the final solute concentration, which depends on the initial concentration and the amount of water vaporized. It was assumed that the ARF is equal to the RARF, even though this assumption may represent a gross conservatism.

1 Superheat is the temperature $\left({ }^{\circ} \mathrm{C}\right)$ of the liquid greater than the boiling point of the solvent in the same temperature scale. 
D.1.2.1.4 Solids: Powders. Two subcategories of powders were considered: combustible and noncombustible. Combustible powders are defined as insoluble nonreactive particles in an organic combustible liquid - the same as the subcategory of organic, combustible slurries.

Combustible Powders. Because the definition of this subcategory is the same as that for organic combustible slurries, the RARF for that material in response to the various stresses was applied here.

Noncombustible Powders. This subcategory represents powders that are normally found in waste facilities - powders that do not burn. The powders are dry, and many are ceramic metallic oxides. The experimental data are generally based on dry uranium dioxide $\left(\mathrm{UO}_{2}\right)$ or titanium dioxide $\left(\mathrm{TiO}_{2}\right)$ but also include data from experiments involving soil or other powders. The following assumptions were used for the stresses:

- Free-Fall Spill. As described previously, the bounding distance was assumed to be $3 \mathrm{~m}$ (10 ft). The measured data for powder from this distance were assigned a bounding ARF of $2 \mathrm{E}-03$, with a RF of 0.3 . The RARF was $6 \mathrm{E}-04$.

- Crush-Impact. No data are available for the suspension of a noncombustible powder due to the impact of a hard unyielding object on the powder or the crush from such an object. It was assumed that such a phenomenon would have an impact no greater than the impact of the powder falling the same distance $(3 \mathrm{~m}[10 \mathrm{ft}])$ onto a bard unyielding surface or a RARF of $6 \mathrm{E}-04$.

- Mechanical Overpressurization (Puncture or Loss of Lid). The suspension of a noncombustible powder due to mechanical action (e.g., puncture, loss of a lid) would be equivalent to the experimentally measured value during the venting of such powders at pressures equal to or less than $0.17 \mathrm{MPa}_{\mathrm{g}}$ (25 psig). The measured values for $\mathrm{ARF}$ and RF were 5E-03 and 0.3 , respectively, resulting in a RARF of $2 E-03$.

- Small Fire. The greater RARF experimentally measured for chemically reactive powders was applied (RARF of $1 \mathrm{E}-02$ ). The experimentally measured value for chemically inert powders (e.g., ceramic oxides) was $6 \mathrm{E}-05$.

- Large Fire. The same factor was applied for a large fire because the presence of heat over a given duration results in the altered chemical state of the material. Therefore, small fires over a long duration may have the same relative effect for this material. 
- Explosive Release: Blast Effects. The RARF derived for the suspension of an enclosed powder during the rapid burning of a volume of a flammable mixture of gases filling less than $25 \%$ of the free volume of the enclosure was 1E-01. The RARF was limited to the RF of the source powder if that fraction was less than 1E-01 (assuming complete deagglomeration of a powder at rest by the action of accelerated gas flow is very conservative). The value is very close to the experimentally measured value for the suspension of powder during the venting of powders pressurized to $3.45 \mathrm{MPa}_{\mathrm{g}}$ (500 psig). If the gas fills the entire free volume of the enclosure, the ARF could be as high as 1.0 (all of the powder), but the RARF was limited to the RF in the source powder. If the powder is not enclosed and is a distance from the burning gases, where the accelerated flow is parallel to the surface on which the powder rests, the RARF would be $2 \mathrm{E}-04$.

- Explosive Release: Shock Effects. An ARF of 8E-01 and a RF of 0.25 are the experimentally measured values for the suspension of soil for explosions of TNT equivalence up to $100 \mathrm{~kg}(220 \mathrm{lb})$. The RARF is for a mass equal to 2E-01 TNT mass equivalence for the explosion. The powder in this case is relatively tightly packed as opposed to the loose, dry ceramic material found in some cases. This value was chosen because it is more representative of the overall conditions that are anticipated (e.g., salt that may be partly fused, damp powders, or powders that have absorbed some moisture). The RARF is a mass of powder 2E-01 of the calculated TNT mass equivalence for the shockgenerating portion of the explosion. This value was limited by the mass of powder in the respirable size range of the mass of material (0.8 TNT equivalence) affected by the explosion.

- Venting of Pressurized Powder. The experimentally measured bounding values for the ARF and RF for the powder pressurized up to $3.45 \mathrm{MPa}_{\mathrm{g}}$ (500 psig) were $1 \mathrm{E}-01$ and 0.5 , respectively. The RARF was $5 \mathrm{E}-02$.

D.1.2.1.5 Solids: Contaminated Combustible Material. Four subcategories were considered for this type of material: (1) dry active waste (DAW - a mixture of combustible wastes [mostly cellulosic materials, but also plastics] in plastic wrapping); (2) unenclosed plastic (polymethyl methacrylate [Lucite], rubber, and elastomer); (3) cellulosic materials (paper, rags, and wood scrap); and (4) polyethylene.

DAW. The following assumptions were used for the stresses:

- Free-Fall Spill. The suspension of sparse surface contamination (particles covering less than $10 \%$ of the surface area to a depth of less than $2 \mathrm{dp}$ ) would not be anticipated to result in substantial entrainment. 
The material itself is relatively light and would not result in a large impact force. The material is encased in plastic wrap and would not release materials suspended unless the plastic wrap loses its integrity. The experimentally measured value (ARF of $1 \mathrm{E}-03$ ) for the suspension of loose dry powder from a hard flexible surface (plywood) was applied, and a very conservative RF of 1.0 was assumed because of the lack of characterization of the potential source materials.

- Crush-Impact. As with other materials, the same factor applied for a free-fall spill was used for the suspension due to crushing or impact (RARF of 1E-3).

- Mechanical Overpressurization (Puncture or Loss of Lid). In the absence of any known experimentally measured values for suspension, the RARF for free-fall spill or vibration (1E-03) was applied.

- Small Fire. For wrapped, contaminated combustible materials, the experimentally measured ARF of $5 \mathrm{E}-04$ for the release of the contaminant during the combustion of contaminated combustible material in cardboard boxes was applied. In the absence of any measured RF values, a conservative value of 1.0 was assumed. The RARF was $5 \mathrm{E}-04$.

- Large Fire. Because of the uncertainty of the fire conditions that may exist, the very conservative ARF (4E-01) experimentally measured for the suspension of a fine, dry powder contaminant during its combustion on a grate with air flowing through the burning mass (similar in effect to a forced-draft furnace) was applied. In the absence of any measured RF, a conservative value of 1.0 was assumed. The RARF was $4 E-01$. Extreme caution should be used in applying this value; the fire conditions should generate conditions similar to a forced-draft furnace before this value is applicable.

- Explosive Release: Blast Effects. Because of its low mass, the entire package would probably be displaced, and the most significant suspension would result from the ignition of the material due to the flame front. The RARF of 5E-04 for a small fire was applied.

- Explosive Release: Shock Effects. The RARF was based on the assumption that the shock effect will fragment a mass of total material equal to the TNT equivalence calculated for the shock-generating mass of the explosive materials. The RARF applied was that fraction of the containment associated with the fragmented mass.

- Venting High Pressure. In the absence of any known experimentally measured values, the very conservative assumption was made that the 
RARF for this material under these conditions would be simulated by the behavior of a loose dry powder. The RARF applied was 5E-02.

Plastics. The values represented here are for the uncovered materials designated (the contaminated surfaces are directly exposed to air). The experimental values were derived for small samples of materials and are very conservative (as the pile of material becomes deeper, the particles and vapors formed by the destruction of the plastic must pass through increasingly deeper beds of ash and residues that may act as a filter or occur on the surface of a sticky high-viscosity mass of melted plastic). As such, the conditions represented here are very uncommon (all waste but that currently in process is contained to some level). These conditions represent extreme values for the situations normally encountered in waste facilities that handle and process radioactive waste. The following assumptions were used for the stresses:

- Free-Fall Spill. The experimentally applied factor measured for the suspension of loose powder from a hard flexible surface from the impact of large (up to $5 \mathrm{lb}_{\mathrm{m}}$ ) debris (i.e., vibration) was applied. Because of the uncertainty of the characteristics of the surface contamination, the measured RF of 0.7 was not applied, and a conservative value of 1.0 was assumed. The recommended RARF is $1 \mathrm{E}-03$.

- Crush-Impact. The experimentally measured value described in the free-fall spill (RARF of 1E-03) was applied.

- Mechanical Overpressurization (Puncture or Loss of Lid). Values for the $\mathrm{ARF}$ and $\mathrm{RF}$ of $5 \mathrm{E}-03$ and 0.3 , respectively, were experimentally measured for the venting of dry ceramic oxide powder at pressures less than $0.17 \mathrm{MPa}_{\mathrm{g}}(25 \mathrm{psig})$. The value of $1 \mathrm{E}-03$ was measured for the suspension of loose ceramic oxide powder from the impact of debris. The ARFs for these two situations that appear to bound the conditions described resulted in RARFs of $1 \mathrm{E}-03$ and 7E-04. A value of $1 \mathrm{E}-03$ was selected to represent this phenomenon on the basis that the value is an average of the two RARFs for the situations and that not all of the surface contamination is available for suspension (it must be loose contamination, and some of the surface contamination is incorporated within the matrix of the material).

- Small Fire. The experimentally measured value for plastics (ARF of 1E-02 with an assumed RF of 1.0 ) was applied. Measured size distributions for airborne material for some plastics indicated that almost all of the materials were in the respirable size range. The value was not as great as measured for the combustion of loose, dry ceramic oxide powder on polymethyl methacrylate, but the experimental configurations represented (piles of loose powder on polymethyl methacrylate granules) were not considered (the residues of surface 
contamination after treatment for removal [e.g., wiping or more rigorous methods] from sheets of polymethyl methacrylate with surface contamination).

- Large Fire. The same values as those applied for small fires were applied for large fires because the formation-and-suspension phenomena (destruction of the substrate and lofting of the particles formed by the vapors generated by the destruction) are the same. A RARF of 1E-02 was applied.

- Explosive Release: Blast Effects. The combustible substrate is ignited by the flame front associated with rapid burning (although the flame front may not be of sufficient duration to ignite some materials), and the value for fires was applied. A RARF of 1E-02 was applied.

- Explosive Release: Shock Effect. If the conservative interpretation of the Steindler and Seefeldt correlation (DOE 1994) is applied to other solid materials, the mass airborne in the respirable size range is equal to the mass TNT equivalence calculated for the explosion (mass = TNT equivalence). The mass concentration of the material of concern on the substrate must be used to determine the mass of the material of concern suspended.

- Venting of High Pressure: The venting of the gases results in violent motion of loose pieces of the substrate, and the surface contamination is suspended by the vibratory action. A RARF of 1E-03 was applied.

Cellulosics. The values presented here are for the designated uncovered materials (i.e., the contaminated surfaces are directly exposed to air). Experimental values were derived for small samples of materials and are very conservative. (As the pile of material becomes deeper, the particles and vapors formed by the destruction of the cellulose must pass through increasingly deeper beds of ash and residues that may act as a filter.) As such, the conditions represented here are very uncommon (all waste but that currently in process is contained to some level) and represent extreme values for the situations normally encountered in waste facilities handling and processing radioactive waste. The following assumptions were used for the stresses:

- Free-Fall Spill. As with all materials in this category, the aerosolization of surface contamination was assumed to result from the vibratory motion from the impact of the substrate upon a hard unyielding surface or by the oscillatory motion of the substrate during the fall. The RARF of $1 \mathrm{E}-03$ was applied. 
- Crush-Impact. As with all materials in this category, the RARF for suspension of the surface contamination was assumed to be equivalent to that for a free-fall spill (1E-03).

- Mechanical Overpressurization (Puncture or Loss of Lid). The RARF for suspension of surface contamination from cellulosics (in most cases, a thin flexible form) is due to vibratory action; the RARF applied was 1E-03.

- Small Fire. The experimental bounding ARF of 1E-02, with an assumed RF of 1.0, was applied for the suspension of surface contamination from small exposed pieces of cellulosic materials. In the absence of measured RFs for these experiments, a conservative value of 1.0 was assumed. The resultant RARF was $1 \mathrm{E}-02$.

- Large Fire. The mechanism of suspension for surface contamination from cellulosic materials is the same for small and large fires. Large fires may include more cellulosic materials, subjecting larger inventories of radionuclides to combustion; however, it is very unlikely that large quantities of contaminated combustible material would be available. Large volumes of cellulosics would mean larger piles of burning cellulose, which would decrease the availability of particles generated within the pile to the surface.

- Explosive Release: Blast Effects. The accelerated flow from the rapid burning uncovers the contaminated cellulosics and ignites the material. The RARF for the burning of exposed contaminated cellulosics $(1.0 \mathrm{E}-02)$ was applied.

- Explosive Release: Shock Effects. The cellulosic substrate is fragmented by the shock like any solid material (particles on the surface of a thin flexible substrate may simply be dislodged and entrained with the resultant flow), and the fraction of contaminant of the substrate would be made airborne with the base material. The mass fraction of the substrate suspended as particles in the respirable size range is equal to the mass of TNT equivalence calculated for the explosion. The mass of the contaminant is determined by multiplying the mass concentration of the contaminant on the substrate by the mass fraction of substrate aerosolized.

- Venting of High Pressure. Venting of high-pressure gas from the free volume above the contaminated material would result in suspension of the surface contamination by vibratory action of the substrate. A RARF (described in previous subsections) of $1 \mathrm{E}-03$ was applied. 
Polyethylene. No direct experimental data exist on the behavior of polyethylene under the stresses covered. Data for other plastics and plasticlike materials (e.g., polymethyl methacrylate, polystyrene, polychloroprene) show that they exhibit very similar behavior. On that basis, the RARFs applied for plastics were applied.

D.1.2.1.6 Solids: Brittle Solids. Materials that shatter, rather than deform, on impact are considered brittle solids. Both vitrified HLW and aggregate HLW (covered subsequently) fall into this class of materials. Vitrified HLW was considered. Vitrified HLW is normally encased in a substantial stainless steel canister that must be compromised before any fragments of the material generated can be made airborne. The behavior described subsequently assumes that the stress either is or is not capable of compromising the canister. The potential airborne release of the contained material assessed is as follows:

- Free-Fall Spill. Canisters must qualify to sustain greater than a 9-m (30-ft) drop to qualify for transport; any vitrified HLW produced is normally poured into such canisters. No compromise of the canister was assumed for these situations.

- Crush-Impact. An empirical correlation of the RF of the fragments generated by crush-impact experiments (using small specimens that were completely covered by the impacting object) yielded the following:

$$
R A R F=(A)(D)(g)(h),
$$

where

$$
\begin{aligned}
& A=\text { empirical correlation coefficient }(2 \mathrm{E}-11), \\
& D=\text { material density }\left(\mathrm{g} / \mathrm{cm}^{3}\right), \\
& g=\text { acceleration due to gravity }\left(980 \mathrm{~cm} / \mathrm{s}^{2}\right), \text { and } \\
& h=\text { height of fall }(\mathrm{cm}) .
\end{aligned}
$$

While this equation is applicable to small specimens of vitrified $\mathrm{HLW}$, applicability to large monoliths, such as HLW poured into a canister, is not known.

- Mechanical Overpressurization (Puncture or Loss of Lid). Although the venting of a $\mathrm{HLW}$ canister at a pressure of less than $0.17 \mathrm{MPa}_{\mathrm{g}}$ (25 psig) is doubtful, on the basis of the value reported for vitrified fragments in the respirable size range found on the waste surface in the upper plenum of a cooled canister (3E-04) and the ARF of 2E-03, a RARF of 7E-07 can be applied to this situation, provided some reason for the venting at such pressures is determined.

- Small Fire. The vitrified HLW is subjected to higher temperatures during formation than those anticipated for any typical industrial fire, and such temperatures are not expected to defeat the stainless steel 
canister. Consequently, no significant airborne release of material was postulated for this situation.

- Large Fire. No significant airborne release was postulated for the impact of a large fire on a vitrified $\mathrm{HLW}$ canister, as described previously.

- Explosive Release: Blast Effects. The RARF was based on the assumptions that the blast occurs in the upper plenum of the canister and that $1 E-01$ of the vitrified HLW fragment (4E-04) found in the upper plenum is suspended. A RARF of $4 \mathrm{E}-05$ was applied.

- Explosive Release: Shock Effects. The mass of vitrified HLW airborne in the respirable size range was assumed to be, as for all other solids, equal in mass to the TNT equivalence calculated for the explosion, but no less than the RARF for blast effects (4E-05).

- Venting of High Pressure. It was assumed that 0.1 of the $4 \mathrm{E}-04$ of the inventory found as fragments of vitrified HLW in the respirable size range after cooling in the upper plenum is suspended; a RARF of 4E-05 was applied.

D.1.2.1.7 Solids: Viscous Liquids. The viscous liquid covered here is molten vitrified waste. No direct experimental evidence exists on the behavior of molten vitrified HLW subjected to the stresses considered. Values were inferred from the effect of viscosity on the release of aqueous liquids. Values for only three stresses (free-fall spill, crush-impact, and shock effect) are recommended at this time. The following assumptions were used for the stresses:

- Free-Fall Spill. On the basis of (1) a model for the fragmentation of liquids on impact following a free-fall and (2) the ratio of the liquids involved ( $<100 \mathrm{cp}$ for an aqueous solution and $>20 \mathrm{P}$ for molten vitrified $\mathrm{HLW}$ ), the calculated RARF for a $3-\mathrm{m}$ (10-ft) distance is $6.5 \mathrm{E}-09$ or about $7 \mathrm{E}-09$.

- Crush-Impact. The impact and crushing by a hard unyielding object on molten vitrified $\mathrm{HLW}$ is equivalent to the free-fall spill and impact of the material.

- Mechanical Overpressurization (Puncture or Loss of Lid). No significant airborne release was postulated for the exposure of molten vitrified $\mathrm{HLW}$ to the ambient environment. If the release results in a spill of the material, application of the RARF for a free-fall spill is appropriate. 
- Small Fire. Because molten vitrified HLW is produced by using equal or higher temperatures than those anticipated for industrial fires, no significant airborne release was postulated for this stress.

- Large Fire. As discussed previously, no significant airborne release was postulated for this stress.

- Blast Effects. No significant airborne release is expected from the impact of accelerated gas flow on the surface or over the surface of molten vitrified HLW because of the high viscosity of the material.

- Shock Effect. Molten vitrified HLW was postulated to behave like the metal or liquids covered in the Steindler and Seefeldt (1980) correlation (DOE 1994). The mass of material fragmented and suspended in the respirable size range was postulated to be equal to the mass calculated for the TNT equivalence of the explosion.

- Venting of High Pressure. Venting of high-pressure gases contained over molten vitrified HLW is not expected to suspend any significant fraction of material from the surface.

D.1.2.1.8 Solids: Metals. Two subcategories of metals were considered: inert and reactive. The reactive metals covered are those that may attain self-sustaining oxidation at an elevated temperature (i.e., uranium [U] and plutonium [Pu]). Other reactive metals such as sodium, are principally hazardous materials, and their behavior should be covered in the consideration of hazardous materials.

Inert Metals. Inert metals (e.g., iron, stainless steel, and aluminum) are not highly chemically active at the normal processing temperature. Except for shock effects and the effects of heat on reactive metal, all of the values for the RARF stated here apply only to the loose corrosion products and contamination on the surface of the metal. If the material suspended is a corrosion product or fragments of the substrate, the amount of the material of concern associated with the inert material must be calculated by multiplying the mass released by the mass concentration of the material of concern. The following assumptions were used for the stresses:

- Free-Fall Spill. The RARF was based on the suspension of powder from the impact of falling debris. The rationale was that the impact of the metal after free-fall would generate an equal amount of stress. The experimentally measured ARF for this phenomenon was $1 \mathrm{E}-03$, with a $\mathrm{RF}$ of 0.7 . Because of the uncertainty of the powder characteristics covered here compared with the experiment powder, a conservative $R F$ of 1.0 was assumed, yielding a RARF of $1 \mathrm{E}-03$ for the loose particulate materials on the surface of the metal. 
- Crush-Impact. The same RARF (1E-03) assumed previously for a freefall spill was applied here.

- Mechanical Overpressurization (Puncture or Loss of Lid by Impact). The experimentally measured suspension during the venting of powder at a pressure of $0.17 \mathrm{MPa}_{\mathrm{g}}(25 \mathrm{psig}$ ) was applied (RARF of $2 \mathrm{E}-03)$.

- Small Fire. The experimentally measured suspension during the heating of nonreactive powders to a temperature up to $1,000^{\circ} \mathrm{C}\left(1,832^{\circ} \mathrm{F}\right)$ in an airflow up to $100 \mathrm{~cm} / \mathrm{s}$ (39 in./s) was applied. The measured ARF was $6 \mathrm{E}-05$. No $R F$ was measured during these experiments; a conservative value of 1.0 was assumed. The RARF was $6 \mathrm{E}-05$ of the loose particulate material on the surface of the metal.

- Large Fire. The same factor as applied for a small fire (6E-05) is applicable here.

- Explosive Release: Blast Effects. The ARF assumed for the rapid burning of a limited volume $(<25 \%$ of the free volume of the container holding the powder) could be applied here for the loose particulate material on the surface of the metal. In most cases, nonreactive metals would be found in large containers, such as enclosures, rooms, or, in some cases, specially built waste containers. The RARF of $1 \mathrm{E}-01$ was limited by the total mass of the particles in that size range in the source powder.

- Explosive Release: Shock Effects. The RARF for shock effects would be the amount of the material of concern associated with the mass of the metal suspended equal to the mass calculated for the TNT equivalence for the explosion. The amount of material suspended should never be less than the amount of material suspended by the blast effects; if the value calculated for the shock effect is less, the amount of material suspended defaults to the blast-effect value.

- Venting of High Pressure. The experimentally measured RARF of 5E-02 during the venting of dry ceramic oxide powder pressurized to $3.45 \mathrm{MPa}_{\mathrm{g}}$ (500 psig) was applied to the loose particulate materials (corrosion products or surface contamination) on the surface of the metal.

Reactive Metals. A reactive metal is a metal that can attain self-sustaining oxidation at elevated temperatures. Except for the impacts of fires and shock, the RARFs stated here apply to the loose corrosion products on the surface of the reactive metal. In some cases, some small differences were found in the response of tht two metals considered 
( $\mathrm{U}$ and $\mathrm{Pu}$ ); the higher values were selected. The following assumptions were used for the stresses:

- Free-Fall Spill. The RARF recommended for the suspension of loose powder (i.e., corrosion products or oxides) on the exposed surfaces of solid materials (1E-03) was applied for this situation.

- Crush-Impact. The stress imposed by the impact of, or the crushing by, a hard unyielding object on the exposed surface of a coherent piece of reactive metal is bounded by the assumptions for the free-fall spill and the impact of the metal on a hard, unyielding surface. The RARF for a free-fall spill (1E-03) for loose powder (corrosion product or oxide) on the surface is recommended.

- Mechanical Overpressurization (Puncture or Loss of Lid by Impact/ Crush). The RARF for the venting of a dry ceramic oxide powder pressurized to $0.17 \mathrm{MPa}_{\mathrm{g}}$ (25 psig) (2E-03) of the loose powder (ceramic oxide or corrosion product) on the surface is recommended to bound the releases from this event.

- Small Fire. The fire is postulated to heat the reactive metal but not have sufficient temperature or duration of burn to achieve self-sustained oxidation. Twice the experimentally measured RARF (ARF of 3E-05 and an assumed RF of 1.0 in the absence of a measured RF) for the suspension from a reactive metal $(\mathrm{Pu})$ during oxidation at elevated temperatures less than that needed to achieve self-sustained oxidation (RARF of 6E-05) is recommended to bound the release for this situation.

- Large Fire. The fire was postulated to be of sufficient intensity and duration to achieve a state of self-sustained oxidation for the reactive metal. Self-sustained oxidation generates molten metal in an oxide coating; the metal becomes elevated in temperature during self-sustained oxidation, and the molten metal in the coat flows and falls. The experimentally measured RARF for the suspension of oxide during the free-fall of small (100-um diameter) drops of molten Pu was 1E-02. The value is sufficiently conservative to bound this situation.

- Venting of High Pressure. The experimentally measured RARF of 5E-02 during the venting of a dry ceramic oxide powder at pressures up to $3.45 \mathrm{MPa}_{\mathrm{g}}(500 \mathrm{psig})$ is recommended to bound the suspension of loose powder on the surface of reactive metals.

D.1.2.1.9 Solids: Noncombustible Aggregate. The most commonly found aggregate in this category is cement or grout. For noncombustible aggregates, the radionuclides can be lying on the surface, incorporated into the surface matrix, or 
incorporated within the body of the aggregate by design. The following assumptions were used for the stresses:

- Free-Fall Spill. Because of the use of aggregate as building material (often as the floor) and as material poured into trenches for entombment, free-fall of the material is not a strong possibility. If pieces of aggregate removed from their initial location are placed in a container for handling and shipping, the crush-impact value, which is discussed subsequently, may be applied, if appropriate.

- Crush-Impact. The empirical correlation applied to the fragmentation of vitrified HLW is also appropriate for this class of materials. (See Equation D2.)

- Mechanical Overpressurization (Puncture or Loss of Lid). Because of the nature of the use of the material, it is often found uncontained. Therefore, a RARF cannot be defined. If fragments or debris are in a container, a RARF of $2 E-03$ of the aggregate in powder form and the radionuclides associated with that fraction may be suspended. The characteristics of such powder are difficult to define and depend on many unspecified factors, such as the method of fragmentation, the condition of the aggregate fragmented, the original composition of the aggregate, the condition after fragmentation, and the conditions of containerization and handling. The RARF is limited by the mass of the particles in the respirable size range in the source powder.

- Small Fire. Aggregate is composed of an appreciable fraction of water, and any bound ${ }^{3} \mathrm{H}_{2} \mathrm{O}$ incorporated into the aggregate would be lost if the temperature of the aggregate reaches $200^{\circ} \mathrm{C}\left(392^{\circ} \mathrm{F}\right)$ or greater.

- Large Fire. If the aggregate reaches a temperature of greater than $600^{\circ} \mathrm{C}\left(1,112^{\circ} \mathrm{F}\right)$ for a sufficient duration, the aggregate decomposes, and $6 \mathrm{E}-03$ of the powder formed plus all of the tritium $\left({ }^{3} \mathrm{H}\right)$ could be released. The conditions do not result in the fragmentation of the powder (calcium oxide [Ca0]) produced, and the RF in the source powder may limit the release of particles in the respirable size range.

- Explosive Release: Blast Effects. Many of the exposed surfaces of contaminated aggregate materials are in occupied areas and, therefore, are stabilized by treatment of the surface.

- Venting of High Pressure. As postulated for blast effects, the contamination of aggregate surfaces in occupied areas is assumed to be stabilized and not subject to resuspension by aerodynamic forces. If loose powder or contamination is on the exposed surfaces of the 
aggregate, venting of high-pressure gases over the exposed surfaces would be bounded by the RARF applied to powders under this stress.

\section{D.1.2.2 Application to Waste Management (WM) Programmatic Environmental Impact Statement (PEIS)}

The RARFs developed in Section D.1.2.1 were applied to the various waste categories and activities. The specific applications are covered subsequently.

\section{D.1.2.2.1 WM PEIS Waste RARFs for LLW, LLMW, and TRUW Storage and} Handling. The RARFs for the activities and accident stresses anticipated during the storage and handling of low-level waste (LLW), low-level mixed waste (LLMW), and transuranic waste (TRUW) are listed in Table D.3; the following assumptions were used for the activities and waste forms for LLW:

1. Noncondensable Gases. The RARF is not applicable. The presence of noncondensable gases in LLW is not anticipated. Radionuclides as noncondensable gases are found in SNF, and in special collection components for SNF reprocessing and are generated by inadvertent nuclear criticalities. The SNF and SNF reprocessing equipment are not classified as LLW. Inadvertent nuclear criticalities are not a credible event for LLW storage or processing.

2. Volatiles. Volatile radionuclides (e.g., $\mathrm{I}_{2}, \mathrm{Ru},{ }^{3} \mathrm{H}$ as ${ }^{3} \mathrm{H}_{2} \mathrm{O}$ or as ${ }^{3} \mathrm{H}$ hydrides) are assumed to exist in LLW as material dissolved in a liquid or as solid compounds and require special physicochemical conditions to be converted to a vapor. Only ${ }^{3} \mathrm{H}$ in the form of ${ }^{3} \mathrm{H}_{2} \mathrm{O}$ or of ${ }^{3} \mathrm{H}$ hydrides is vaporized by heat alone; other radionuclides require additional conditions such as an acidic environment or an oxidant.

\section{Organic Combustible Liquids}

a. Solutions

(1) Spills. Assume free-fall of solution $3 \mathrm{~m}$ (10 ft) or less and impact with hard unyielding surface.

(2) Crush-Impact. Crush without restraint of the liquid is not considered an efficient airborne droplet-generation mechanism, and suspension from the impact of an object on the liquid surface appears to be the more dominant droplet-generation mechanism. Assume that the suspension of droplets in the respirable size range from the impact of an object over a portion of the surface of the liquid is bounded by the suspension of 
droplets in the respirable size range by the impact of the solution onto a hard unyielding surface.

(3) Pressurized Release. Pressurized release assumes the rapid ( $<1 \mathrm{~min}$; does not allow the absorption of the gases into the liquid) pressurization to $1.38 \mathrm{MPa}_{\mathrm{g}}$ (200 psig) or less of the free volume above the liquid and the venting of the pressurized liquid through an opening equivalent to an orifice with a diameter of $1 \mathrm{~mm}$ ( $0.04 \mathrm{in}$.) or more at the bottom of the sidewall of the vessel or container.

(4) Small Fire (less than the entire inventory is involved, and the structural containment is not impaired). The RARF for any iodine dissolved in the liquid is 1.0. The RARF for all other radionuclides is based on the maximum measured experimental value for suspension of particles in the respirable size range during the burning of an organic combustible liquid with a residue (liquid or moist sludge) (1E-02).

(5) Large Fire (almost the entire inventory is involved, and the structural containment is damaged). The RARF for any iodine dissolved in the liquid is 1.0E. The RARF for all other radionuclides is the maximum experimental value measured for the suspension of particles in the respirable size range during the burning of a contaminated, organic combustible liquid to complete dryness (1E-01).

(6) Deflagration (Blast Effects). Droplets can be generated by the passage of gas at an accelerated velocity over the surface of the liquid (shear stress) and by the ignition of the organic combustible liquid by the passage of the flame front over the liquid. The RARF for shear stress is $4 \mathrm{E}-03 / \mathrm{h}$ for the duration of the passage of the pressure impulse (assume $1 \mathrm{~min}$ ), resulting in a value of $7 \mathrm{E}-05$. This RARF is greatly exceeded by the RARF for a large fire (1E-01).

(7) Detonation (shock effects). The RARF applied is the sum of the releases from fragmentation and suspension from the liquid due to shock effects and the RARF for the passage of the pressure impulse without ignition of the liquid (detonations normally occur within a microsecond to millisecond, and the flame front is not present for a sufficient period of time to result in the ignition of the liquid). The RARF for the shock effect is a conservative interpretation of the Steindler and Seefeldt (1980) correlation for the fragmentation and suspension of drops in the respirable size range by detonation on or in liquids and solids; 
the mass of material airborne in the respirable size range is equal to the mass of the TNT equivalence calculated for the explosion.

(8) Pressurized Releases. Suspension occurs during the venting of a slow ( $>1 \mathrm{~min}$ pressurization period that allows the pressurizing gases to be absorbed into the liquid) pressurization of the free volume above the liquid to a pressure of $3.45 \mathrm{MPa}_{\mathrm{g}}$ (500 psig) through an opening near the surface of the liquid or at the bottom of the sidewall of the vessel or container.

b. Slurries

(1) Spills. The RARF is based on the suspension of particles in the respirable size range from the free-fall from a distance of $3 \mathrm{~m}$ $(10 \mathrm{ft})$ or less and the impact of aqueous slurries on a hard unyielding surface. If the radionuclides are involved with only the particulate materials present, the airborne release may be limited by the amount of particles in the respirable size fraction present in the source material.

(2) Crush-Impact. (See point 3.a.2.) A slurry has two components: the liquid and the particles. If the radionuclides are associated with the particle fraction, the airborne release may be limited by the fraction of particles in the respirable size range found in the particle component.

(3) Pressurized Release. (See points 3.a.3 and 3.b.2.)

(4) Small Fire (less than the entire inventory is involved, and structural containment is not impaired). (See point 3.a.4.) If the radionuclides are dissolved in the organic combustible liquid, the applicable RARF would be the suspension during the burning of the liquid (1E-02). If the radionuclides are involved only with the nonreactive particle component, the applicable RARF is for the suspension of particles in the respirable size range during the heating of a nonreactive powder (6E-05).

(5) Large Fire (almost the entire inventory is involved, and structural containment is damaged). (See points 3.a.5 and 3.b.4.)

(6) Deflagration (Blast Effects). (See point 3.a.6.) If the radionuclides are dissolved in the organic combustible liquid and the combustible solvent is ignited, the RARF for the burning of the combustible liquid ( $1 \mathrm{E}-01$ ) would dominate the releases. If 
the radionuclides are associated only with the nonreactive particle fraction, the applicable RARF is for the suspension of particles in the respirable fraction by the result of heating of the nonreactive powder $(6 \mathrm{E}-05)$.

(7) Detonation (Shock Effects). (See point 3.a.7.) If the radionuclides are associated with the particle fraction, suspension by shear stress (aerodynamic entrainment) is possible, although the presence of the liquid increases the force necessary to suspend the particles. The most applicable RARF is a conservative interpretation of the Steindler and Seefeldt (1980) correlation for the fragmentation and suspension of particles in the respirable size range due to detonations on or in solids and liquids: the mass of particles in the airborne respirable size range is equal to the mass of the TNT equivalence of the explosion.

(8) Pressurized Release. (See point 3.a.8.) If the radionuclides are associated with only the particle fraction, the airborne release of particles in the respirable size range may be limited by the amount of material in that range in the source material.

\section{Aqueous Liquids}

a. Solutions

(1) Spills. (See point 3.a.1.)

(2) Crush-Impact. (See point 3.a.2.)

(3) Pressurized Release. (See point 3.a.3.)

(4) Small Fires (less than the entire inventory is involved, and structural containment is not impaired). The RARF is based on the maximum value measured for the suspension of droplets in the respirable size range during the heating and boiling of aqueous solutions (2E-03). The RARF is not applicable to the churn-turbulent or chaotic boiling regimes.

(5) Large Fires (almost the entire inventory is involved, and structural containment is damaged). (See point 4.a.4.)

(6) Deflagration (Blast Effects). The RARF is based on the suspension of drops in the respirable size range by the passage of air at an accelerated velocity over the surface of an aqueous solution (shear stress). The ARF is $4 \mathrm{E}-03 / \mathrm{h}$ from a hard unyielding surface for velocities in excess of $32 \mathrm{~km} / \mathrm{h}(20 \mathrm{mi} / \mathrm{h})$. 
A conservative estimate of $1 \mathrm{~min}$ is applied for the time of passage of the pressure impulse over the surface of the liquid, resulting in a RARF of 7E-05.

(7) Detonation (Shock Effect). (See point 3.a.7.)

(8) Pressurized Release. (See point 3.a.8.)

b. Slurries

(1) Spills. (See point 3.b.1.)

(2) Crush-Impact. (See point 3.a.2.)

(3) Pressurized Release. (See points 3.a.3 and 3.b.2.)

(4) Small Fire (less than the entire inventory present is involved, and structural containment is not impaired). (See point 4.a.4.) If the inventory is involved with the nonreactive particulate fraction of the slurry, the RARF is based on the maximum values measured for the suspension of particles in the respirable size range during the heating of nonreactive powders on a hard unyielding surface.

(5) Large Fire (almost the entire inventory of radionuclides is involved, and the structural containment is damaged). (See points 4.a.4 and 4.b.4.)

(6) Deflagration (Blast Effects). Droplets in the respirable size range can be generated by the passage of accelerated gas velocities over the surface of the aqueous solution. If the inventory is dissolved in the aqueous phase or uniformly distributed in the aqueous phase, the RARF for this mechanism is based on the aerodynamic entrainment (shear stress) rate of $4 \mathrm{E}-03 / \mathrm{h}$ for an assumed duration of $1 \mathrm{~min}$ for the passage of the pressure impulse, resulting in a RARF of $7 \mathrm{E}-05$. If the inventory is involved with the particulate phase and that phase is not exposed to the surface of the liquid, a RARF of less than $1 \mathrm{E}-05$ can be postulated for this phenomenon.

(7) Detonation (Shock Effects). The RARF for radionuclides dissolved in the aqueous phase or in particulates uniformly distributed in the aqueous phase is based on a conservative interpretation of the Steindler and Seefeldt (1980) correlation. This correlation predicts the fragmentation and suspension of particles in the respirable size range from detunations on or in the material; the mass of particles airborne in the respirable size 
range is equal to the mass of the TNT equivalence estimated for the explosion.

(8) Pressurized Release. (See points 3.a.8 and 3.b.8.)

c. Superheated Aqueous Liquids

(1) Spills. The spill of the container defeats the vessel or container and the superheated liquid is released to the atmosphere. The RARF is based on the maximum measured value for the suspension of droplets in the respirable size range from the venting of aqueous liquids superheated to $50-100^{\circ} \mathrm{C}\left(122-212^{\circ} \mathrm{F}\right)$ above the boiling point of the solvent (water); the liquid forms a flashing spray with a RARF of 7E-02.

(2) Crush-Impact. The event defeats the vessel or container holding the superheated aqueous liquid and the release results in a flashing spray of the aqueous liquid, as in point 4.c.2.

(3) Pressurized Release. The pressure generated by the heated liquid defeats the structural containment, allowing the release of the liquid and the formation of a flashing spray. The RARF is $7 \mathrm{E}-02$.

(4) Small Fire (less than the entire inventory of radionuclides is involved, and the structural containment is not impaired). The assumption is that the event defeats the vessel or container holding the superheated liquid, which forms a flashing spray. The RARF is $7 \mathrm{E}-02$.

(5) Large Fire (almost the entire inventory of radionuclides is involved, and the structural containment is damaged). The event defeats the vessel or container holding the superheated liquid, which forms a flashing spray. The RARF is 7E-02.

(6) Deflagration (Blast Effects). The event defeats the vessel or container and releases the superheated liquid, which flashes. The RARF is 7E-02.

(7) Detonation (Shock Effect). The event defeats the vessel or container and releases the superheated liquid, which flashes. The RARF is the sum of the RARF in point 4.c.1 and the conservative interpretation of the predicted airborne release of solids and liquids from detonations on or in materials. The mass of the drops in the respirable size range is equal to the mass of the TNT equivalence estimated for the explosion. 


\section{Powders}

a. Combustible Powders (nonreactive Powder Mixed with an Organic Combustible Liquid; a Powder Slurry)

(1) Spill (Free-Fall Spill of Powder $3 \mathrm{~m}[10 \mathrm{ft}]$ or Less). Although the presence of the organic combustible liquid undoubtedly increases the forces required to separate the particles, the RARF is based on the maximum experimental value measured for the suspension of particles in the respirable size range from the free-fall spill of a dry ceramic powder $3 \mathrm{~m}$ (10 ft) or less and the impact against a hard unyielding surface. If the radionuclides are associated with the liquid, the RARF in point 3.b.1 is applicable.

(2) Crush-Impact (Crush or Impact of Slurry by Objects). No experimental data exist on the effect of crush-impact forces on the subdivision and suspension of organic sludges or slurries. The suspension is assumed to be conservatively bounded by the RARF measured for the deagglomeration and suspension of uncontained dry ceramic powders from a stiff, flexible nonporous surface by the impact of objects (1E-02).

(3) Pressurized Release (Venting of Volume Pressurized to 3.45 $\mathrm{MPa}_{\mathrm{g}}[500 \mathrm{psig}]$ or Less Containing the Powder). The RARF is based on the maximum experimental value measured for the deagglomeration and suspension of a dry ceramic powder pressurized to $3.45 \mathrm{MPa}_{\mathrm{g}}$ (500 psig) or less during venting. The RARF can be limited by the amount of particles in the respirable size range present in the source powder slurry.

(4) Small Fire (less than the entire inventory of radionuclides is involved, and the containment of the facility is not impaired). (See point 3.b.4.) If the inventory of radionuclides is associated with the nonreactive particle phase of the slurry, the RARF for the maximum experimental value measured for the suspension of particles during the heating of a dry, ceramic nonreactive powder $(6 \mathrm{E}-05)$ is applicable.

(5) Large Fire (almost the entire inventory of radionuclides is involved, and the containment of the facility is damaged). (See points 3.b.6 and 5.a.4.)

(6) Deflagration (Fast Burning of a Flammable Mixture of Gases: Blast Effects). The RARF is based on the suspension of nonvolatile radionuclides dissolved in an organic combustible 
liquid during burning (after ignition of the organic combustible liquid by the passage of the flame front) to complete dryness (no wet or moist residue). If the inventory of radionuclides is associated with the particle component of the slurry, the RARF is that for the suspension due to blast effects from deflagrations of a mixture of flammable gases that fills less than $25 \%$ of the volume directly over the powder. The RARF for the suspension of powder may be limited by the amount of particles in the respirable size range found in the source powder slurry.

(7) Detonation (Reaction Completed in Microseconds to Milliseconds). The RARF is based on a conservative interpretation of the Steindler and Seefeldt (1980) correlation that predicts the fragmentation and suspension of particles in the respirable size range from detonations on or in solids and liquids. The RARF for this shock effect is the mass of particles airborne in the respirable size range equal to the mass of the TNT equivalence estimated for the explosion. The blast effects for the event are additive, but ignition of the organic combustible liquid cannot be postulated because of the speed of the reaction. If the inventory is associated with the powder fraction of the powder slurry, the blast effect shown in point 5.a.5 would probably dominate the RARF. If the blast effect dominates, the RARF may be limited by the amount of particles in the respirable size range present in the powder slurry.

(8) Pressurized Release (Venting of Volumes Pressurized to $3.45 \mathrm{MPa}_{\mathrm{g}}[500 \mathrm{psig}]$ Containing the Slurry). (See point 5.a.3.)

b. Noncombustible Powders

(1) Spills (Free-Fall Spills of Powder $3 \mathrm{~m}[10 \mathrm{ft}]$ or Less). (See point 5.a.1.)

(2) Crush-Impact (Crush or Impact of Object on Powder). (See point 5.a.2.)

(3) Pressurized Release (Venting of Volume Containing the Powder That Has Slowly Been Pressurized up to $3.45 \mathrm{MPa}_{\mathrm{g}}$ [500 psig] before Release). (See point 5.a.3.)

(4) Small Fire (less than the entire inventory of radionuclides is involved, and the containment of the facility is not impaired). The RARF is based on the maximum value measured for the 
suspension during the heating of a reactive powder in an upflow of air with a velocity of $100 \mathrm{~cm} / \mathrm{s}(39 \mathrm{in} . / \mathrm{s})(1 \mathrm{E}-02)$.

(5) Large Fire (almost the entire inventory of radionuclides is involved, and the containment of the facility is damaged). (See point 5.b.2.)

(6) Deflagration (Blast Effect; Rapid Burning of a Flammable Gas Mixture). The RARF is that selected for deflagration of a flammable gas mixture that fills less than $25 \%$ of the free volume directly over the powder.

(7) Detonation (Shock Effect; Reactions Completed in Microseconds to Milliseconds). The applicable RARF is the sum of the RARFs for the shock and blast effects. The RARF for the shock effect is based on a conservative interpretation of the Steindler and Seefeldt (1980) correlation that predicts the fragmentation of solids and liquids from detonations on or in the materials: the mass of particles in the respirable size range suspended is equal to the mass of the TNT equivalence estimated for the explosion. The blast-effect RARF is given in point 5.b.6, (1E-01) and probably dominates the shock-effect RARF. Because it cannot be postulated that the blast will further subdivide the powder, the RARF may be limited by the amount of particles in the respirable size range present in the source powder (the source powder must have a fraction of particles in the respirable size range greater than $10 \%$ ).

(8) Pressurized Release (Venting of the Volume Holding the Powder That Has Slowly Been Pressurized to $3.45 \mathrm{MPa}_{\mathrm{g}}$ [500 psig] before the Release). (See point 5.a.3.)

\section{Contaminated Combustible Solids}

a. DAW (Dry Active Waste; Contaminated Combustibles Wrapped in an Uncontaminated Wrapper)

(1) Spill. The free-fall and impact of DAW on a hard, unyielding surface can be postulated to result in the loss of the wrapping and the suspension of particulate contamination by shock or vibration. No direct data exist for the suspension of particles in the respirable size range from light flexible materials such as paper, rags, or plastic wrapping. It was assumed, however, that the RARF is bounded by the maximum value measured for the suspension of powder in this size range due to the impact of 
objects on uncontained, dry ceramic powder on a stiff, flexible nonporous surface (1E-03).

(2) Crush-Impact. Crush or impact by objects can be postulated to result in the loss of containment of the wrapping and the suspension of particulate contamination from the surface by shock or vibration forces. (See point 5.a.1.)

(3) Pressurized Release. Rapid pressurization of the volume containing the DAW to a pressure of $1.38 \mathrm{MPa}_{\mathrm{g}}(200 \mathrm{psig})$ or less can be postulated to defeat the vessel containment and to eject the DAW. Impact of the DAW with a hard unyielding surface or other object can be postulated to defeat the wrapping and suspend the particulate surface contamination by shock or vibration. (See point 5.a.1.)

(4) Small Fire (less than the entire inventory of radionuclides is involved, and the containment of the facility is not impaired). The RARF is based on the maximum experimental value measured for the suspension of particles during the burning of a mixture of contaminated combustible waste packaged in plastic and cardboard (5E-04).

(5) Large Fire (almost the entire inventory of radionuclides is involved, and the containment of the facility is damaged). The RARF is based on the assumption that the force of the impact of aircraft parts on the waste packages is sufficient to free the contaminated combustible materials from their wrapping and to disperse them into the air, where the combustible materials ignite due to the burning of the aircraft fuel and burn before falling to the ground. The scenario requires extreme force to be brought to bear on the packages. The RARF is based on the maximum experimental value measured during the burning of tissue paper contaminated with a very fine, dry ceramic powder while suspended in flowing air (4E-01). The RARF may be limited by the amount of particles in the respirable size fraction present in the source powder contaminant.

(6) Deflagration (Rapid Burning of a Flammable Gas Mixture: Blast Effect). The RARF is based on the assumptions that the pressure impulse from the deflagration disperses the entire wrapped material and that the wrapping is ignited by the passage of the flame front (5E-04).

(7) Detonation (Reaction Completed in Microseconds to Milliseconds: Shock Effect). The RARF is the sum of the RARFs for both 
shock and blast effects. The RARF for the shock effect is a conservative interpretation of the Steindler and Seefeldt (1980) correlation that predicts the fragmentation of solids and liquids from detonation on or in the material. The mass of particles in the respirable size range suspended is equal to the mass of the TNT equivalence estimated for the explosion. The contaminated combustible materials cannot be postulated to ignite because of the speed of the reaction. The RARF for the blast effect is based on the suspension of contamination from surfaces by shock or vibration (1E-03).

(8) Pressurized Release (Venting of the Volume Holding the Material That Has Been Pressurized before Release to $3.43 \mathrm{MPa}_{\mathrm{g}}[500 \mathrm{psig}]$ ). The event cannot be postulated to eject the contaminated combustible waste without altering its state; however, the wrapping is defeated by the impact of the material with a hard, unyielding surface, and the particulate contamination is suspended by the shock or vibration. The RARF of 1E-03 can be applied.

b. Plastics (All Solid Combustible Plastics and Elastomers except Polystyrene)

(1) Spill (Free-Fall of the Plastic Contaminated with a Solid Material). No direct experimental data exist for the suspension of particulate contamination from the surface of plastics as a result of the free-fall and impact of the plastic on a hard unyielding surface. It was assumed that the release is bounded by the maximum experimental value measured for the suspension of particles in the respirable size range by the impact of falling objects onto uncontained dry powder resting on a stiff, flexible nonporous surface (1E-03).

(2) Crush-Impact (Impact of a Moving Object on the Material). No direct experimental data are available for the suspension of particles from the surface of contaminated plastics. (See point 6.a.1.)

(3) Pressurized Release (Venting of a Volume Holding the Material That Has Been Rapidly Pressurized to $3.45 \mathrm{MPa}_{\mathrm{g}}[500 \mathrm{psig}]$ and Less before Release). No direct experimental measurements exist for the suspension of particulate contamination from the surface of plastic by the pressurized release of the material. (See point 6.a.3.) 
(4) Small Fire (less than the entire inventory of the radionuclides is involved, and the containment of the facility is not impaired). The RARF (1E-02) is based on the maximum experimental value measured for the suspension of particles in the respirable size range during the burning of plastics and elastomers contaminated with powders and aqueous solutions in flowing air (up to $100 \mathrm{~cm} / \mathrm{s}$ [39 in./s]).

(5) Large Fire (almost the entire inventory of radionuclides is involved, and the containment of the facility is not impaired). Because of the weight of the material, plastics cannot be postulated to remain airborne while burning, and the RARF for suspension of contaminant during simple burning is applicable. (See point 6.b.4.)

(6) Deflagration (Rapid Burning of a Flammable Gas Mixture: Blast Effects). The RARF is based on the assumption that the contaminated combustible material is ignited by the passage of the flame front; the RARF for the burning of contaminated plastics applies (1E-02).

(7) Detonation (Reaction Completed in Microseconds to Milliseconds: Shock Effects). The RARF is the sum of the RARFs for the shock and blast effects. The RARF for the shork effect is based on a conservative interpretation of the Steindler and Seefeldt (1980) correlation that predicts the fragmentation of solid and liquids from detonation on or in the material. The mass of the particles in the respirable size fraction suspended is equal to the mass of the TNT equivalence estimated for the explosion. The mass suspended is that of the contaminated plastic, and the amount of radionuclide suspended depends on the concentration of radionuclide present. The RARF for the suspension due to blast effect without ignition of the combustible materials is difficult to ascertain because the material itself would be displaced by the accelerated airflow. The RARF selected is that for the suspension due to shock or vibration (1E-03).

(8) Pressurized Release (Venting of the Volume Holding the Material That Has Been Slowly Pressurized [ $>1 \mathrm{~min}$ ] up to $3.45 \mathrm{MPa}_{\mathrm{g}}[500 \mathrm{psig}]$ before the Release). (See point 6.b.3.)

c. Cellulosics (All Cellulose Materials Such as Paper, Rags, Wood, Cardboard, etc.). The contaminated surface of the material was assumed to be exposed to the atmosphere. 
(1) Spill (Free-Fall of the Material and Impact with a Hard, Unyielding Surface). No direct experimental data exist on the suspension of solid contaminants from the surface of cellulosic material as a result of the free-fall and impact of the material on a hard unyielding surface. (See point 6.a.1.)

(2) Crush-Impact (Crush-Impact of Material by a Moving Object). No direct experimental data exist on the suspension of particulate contamination from the surface of cellulosic materials by crush-impact forces. (See point 6.a.1.)

(3) Pressurized Release (Venting of Volume Holding Material That Has Been Rapidly Pressurized to $3.45 \mathrm{MPa}_{\mathrm{g}}$ [500 psig] before Release). No direct experimental data exist for the suspension of particulate contamination from the surface of cellulosic material by the airborne transport of the material and impact with a hard unyielding surface. (See point 6.a.1.)

(4) Small Fire (less than the entire inventory of radionuclides is involved, and the containment of the facility is not impaired). The RARF is based on the maximum experimental value measured for suspension of particles in the respirable size range during the burning of the uncontained contaminated material in flowing air (1E-02).

(5) Large Fire (almost all of the inventory of radionuclides is involved, and the containment of the facility is damaged). For the purpose of this scenario, the extremely conservative assumption was made that the event would defeat the package containment, make the material airborne, and ignite and burn the contaminated material while it is airborne. For materials with a large surface-to-volume ratio and a low mass, keeping the material airborne while it burns may be possible. The likelihood that a substantial fraction of the inventory will show this behavior is much less probable. Nonetheless, the RARF is based on the maximum experimental value measured for the suspension of particles from the burning of tissue paper contaminated with a dry ceramic powder while it is suspended in a flow of air greater than $100 \mathrm{~cm} / \mathrm{s}(39 \mathrm{in} . / \mathrm{s})(4 \mathrm{E}-01)$.

(6) Deflagration (Rapid Burning of a Flammable Mixture of Gas: Blast Effect). This scenario assumes that the contaminated combustible material is ignited by the passage of the flame front; the RARF is based on the suspension of material during burning of the material. (See point 6.c.4.) 
(7) Detonation (Reactions Completed in Microseconds to Milliseconds: Shock Effects). The RARF is a sum of the RARFs for shock and blast (without ignition of the contaminated combustible material) effects. The RARF for the shock effect is a conservative interpretation of the Steindler and Seefeldt (1980) correlation that predicts the fragmentation of solids and liquids due to a detonation on or in the material. The mass of particles in the respirable size range is equal to the mass of the TNT equivalence estimated for the explosion. The mass of material fragmented is the contaminated combustible material; the amount of radionuclides made airborne with this mass depends on the concentration of the radionuclides on the combustible material. The RARF for the blast effect is the suspension of the powder from the surface of the cellulosic material due to the accelerated gas velocity resulting from the detonation. The estimation of the suspension under this circumstance is complicated by the movement of the light cellulosic that may have a high surface-to-mass ratio. The RARF for this condition can be postulated to be bounded by the RARF assumed for the suspension of surface contamination due to shock or vibration (1E-03).

(8) Pressurized Release (Venting of the Volume Holding the Contaminated Combustible Material That Was Slowly [ $>1 \mathrm{~min}$ ] Pressurized to $3.45 \mathrm{MPa}_{\mathrm{g}}$ [500 psig] or Less). (See point 6.c.3.)

d. Polystyrene (Polystyrene Beads Such as Ion-Exchange Resin)

(1) Spill (Free-Fall and Impact on a Hard, Unyielding Surface of the Polystyrene). No direct experimental data exist on the suspension of particulate surface contamination from the freefall and impact of small pieces of polystyrene. The RARF is based on the assumption that the RARF will be bounded by the maximum experimental value measured for the suspension of an unrestrained, dry ceramic powder from a stiff, flexible nonporous surface by the impact of moving objects (1E-03).

(2) Crush-Impact (Crush or Impact of Moving Object on Contaminated Polystyrene). No direct data exist on the suspension of particulate surface contamination from polystyrene pieces as a result of the impact of moving objects. The RARF is based on the assumption that the RARF will be bounded by the suspension of an unrestrained, dry ceramic powder by the impact of falling objects (1E-03). 
(3) Pressurized Release (Venting of the Volume Containing the Contaminated Polystyrene Rapidly Pressurized up to $3.45 \mathrm{MPa}_{\mathrm{g}}$ [500 psig]). No direct experimental data exist on the suspension of solid particulate contamination from the surface of polystyrene pieces during the airborme transport of the material. The RARF is based on the maximum experimental value measured for the suspension of an unrestrained, dry ceramic powder due to the impact of falling objects (1E-03).

(4) Small Fire (less than the entire inventory of radionuclides is involved, and the confinement of the facility is unimpaired). The RARF is based on the maximum experimental value for the suspension of particles in the respirable size range during the burning in flowing air of polystyrene contaminated with liquid (1E-02).

(5) Large Fire (almost the entire inventory of radionuclides is involved, and the confinement of the facility is damaged). (See point 6.d.4.)

(6) Deflagration (Rapid Burning of a Flammable Mixture of Gas; Reaction Completed in Milliseconds to Seconds; Blast Effects). No direct experimental value was found for the suspension of surface contamination from the surface of polystyrene under accelerated gas flow. The scenario assumed here is the deflagration of a flammable mixture that fills up to $25 \%$ of the free volume directly over the powder, leading to a RARF of $1 E-01$ of the powder on the surface of the poly.styrene.

(7) Detonation (Reaction Completed in Microseconds to Milliseconds; Shock Effects). The RARF is the sum of the shock and blast effects from a detonation. The RARF for the shock effect is based on a conservative interpretation of the Steindler and Seefeldt (1980) correlation that predicts the fragmentation of solids and liquids as a result of a detonation on or in the material. The mass of particles in the respirable size range airborne is equal to the mass of the TNT equivalence estimated for the explosion. The RARF is for the blast effects outlined in point 6.d.6.

(8) Pressurized Release (Venting of the Volume Containing the Contaminated Polystyrene That Has Been Slowly [>1 min] Pressurized to $3.45 \mathrm{MPa}_{\mathrm{g}}$ [500 psig]). (See point 6.d.3.)

7. Brittle Solids. (Solids That May Undergo Brittle Fracture under Crush-Impact Stress). For the purposes of these analyses, the brittle 
materials under consideration are vitrified HLW, and, therefore, RARFs are not applicable. Other physical forms that may undergo brittle fracture under crush-impact stresses (aggregates such as concrete) are covered in point 10 under noncombustible aggregate solids.

8. Viscous Liquids. Viscous liquids have many forms, such as sludges and non-Newtonian fluids. The form of primary concern to these analyses is the molten vitrified HLW not found in LLW. The RARFs for this physical form are not applicable here.

9. Metals.

a. Inert (Nonreactive under Normal Atmospheric Conditions)

(1) Spills (Free-Fall of Metal and Impact with a Hard, Unyielding Surface). No direct experimental data exist for the suspension of loose, particulate contamination from the surface of metal during free-fall or impact with a hard unyielding surface. The RARF is based on the assumption that the RARF will be bounded by the maximum experimental value measured for the suspension of particles in the respirable size range by the impact of a falling object from unrestrained, dry ceramic powder on a stiff, flexible nonporous surface (1E-03). The materials at risk in this case are the radionuclides contained in the loose, particulate surface contamination. Radionuclides that have been absorbed into the metal matrix by prior conditions or treatment may be vulnerable if the surface of the inert metal has been subject to corrosion during the long storage period.

(2) Crush-Impact (Crush or Impact by a Moving Object). No direct experimental data exist for the suspension of loose particulate contamination from the surface of metals by crush or impact stresses. The RARF is based on the assumption that the RARF will be bounded by the maximum experimental value for the suspension of particles in the respirable size range by the impact of falling objects on unrestrained, dry ceramic powder on a stiff, flexible nonporous surface (1E-03). (See point 9.a.1 for materials at risk.)

(3) Pressurized Release (Venting of Volume Rapidly Pressurized to a Pressure up to $3.45 \mathrm{MPa}_{\mathrm{g}}[500 \mathrm{psig}]$ Holding the Contaminated Metal). No direct experimental data exist for the suspension of loose particulate contamination from the surface of metal pieces during transport through the air or on impact. The RARF is based on the assumption that the RARF will be bounded by the maximum experimental value for the suspension of a dry 
ceramic powder during venting (5E-02). (See point 9.a.1 for materials at risk.)

(4) Small Fires (less than the entire inventory of radionuclides is involved, and the confinement capability of the facility is not impaired). The RARF is based on the maximum experimental value measured during the heating of a nonreactive, dry ceramic powder on a hard unyielding surface in flowing air (6E-05). (See point covered in 9.a.1 for materials at risk.)

(5) Large Fire (almost the entire inventory of radionuclides is involved, and the confinement capability of the facility is damaged). (See point 9.a.4.)

(6) Deflagration (Rapid Burning [Reaction Completed in Milliseconds to Seconds] of a Flammable Mixture of Gas: Blast Effects). No direct experimental data exist on the suspension of particles in the respirable size range as the result of a deflagration near or over an unrestrained, dry ceramic powder. The RARF is based on the value assumed for the suspension of particles from an unrestrained, dry ceramic powder on a hard unyielding surface as the result of the deflagration of a flammable mixture of gas filling less than $25 \%$ of the free volume available directly over the powder (1E-01). (See point 9.a.1 for materials at risk.) The RARF may be limited by the amount of particles in the respirable size range present in the loose, particulate surface contamination.

(7) Detonation (Reaction Completed in Microseconds to Milliseconds: Shock Effects). The RARF is the sum of the shock and blast effects from the explosion. The RARF for the shock effects is based on a conservative interpretation of the Steindler and Seefeldt (1980) correlation that predicts the fragmentation of metals and liquids by detonation on or in the material. In this case, the RARF is applied to the total metal mass, and the radionuclides suspended are the radionuclides associated with the fraction of metal made airborne. The RARF for the blast effects is given in point 9.a.6 (1E-01).

(8) Pressurized Release (Venting of the Volume Holding the Metal That Has Been Slowly Pressurized to $3.45 \mathrm{MPa}_{\mathrm{g}}$ [500 psig] before Release). (See point 9.a.3.) 


\section{b. Reactive Metals (Uranium; Plutonium)}

(1) Spill (Free-Fall and Impact onto a Hard, Unyielding Surface of the Reactive Metal). Reactive metal has a greater potential for corrosion under storage conditions (varying temperature, oxygen availability, presence of moisture). However, because corrosion is a function of the surface area and LLW does not normally contain large pieces of reactive metal, the effect of corrosion is limited. Very small pieces of reactive metal stored for long periods of time may well be present as pockets of oxide powder. No direct experimental data exist for the suspension of particles in the respirable size range from corroded surfaces of reactive metal during free-fall and impact with hard unyielding surfaces. The RARF is based on the assumption stated in point 9.a.1 and is $1 E-03$. The materials at risk for this event are outlined in point 9.a.1.

(2) Crush-Impact (Crush or Impact of Moving Object onto Reactive Metal). (See point 9.b.1.)

(3) Pressurized Release (Venting of the Volume Holding the Reactive Metal That Has Been Rapidly [ $<1 \mathrm{~min}$ ] Pressurized up to $3.45 \mathrm{MPa}_{\mathrm{g}}$ [500 psig]). No direct experimental data exist for the suspension of loose particulate material from the surface of reactive metal by the accelerated velocities present during the venting or, if the metal pieces are ejected from the volume by the venting, during transport through the air and impact with a hard unyielding surface. The RARF is based on the assumption that the suspension of any loose, particulate surface material will be bounded by the maximum experimental value measured for the suspension of particles in the respirable size range during the venting of a dry ceramic powder slowly pressurized to $3.45 \mathrm{MPa}_{\mathrm{g}}$ (500 psig) (5E-02).

(4) Small Fire (less than the entire inventory of radionuclides is involved, and the confinement capability of the facility is not impaired). Reactive metals oxidize as a function of temperature and oxygen availability. At a temperature that is a function of the surface-to-mass ratio, the metal may achieve a state of self-sustained oxidation. For bulk pieces (surface-to-mass ratio $<10 \mathrm{~cm}^{2} / \mathrm{g}$ ), the suspension of particles from the oxidizing surface in flowing air has a maximum experimental value of $6 \mathrm{E}-04$, which was selected for this event. If the reactive metal is postulated to have completely oxidized in storage before the event, the RARF shown in point $9 . b .3(5 \mathrm{E}-02)$ is applicable if 
the severity of impact of aircraft parts is postulated to make the LLW airborne.

(5) Large Fire (almost the entire inventory of radionuclides is involved, and the confinement capability of the facility is damaged). (See point 9.a.4.) If the reactive metal is postulated to exist in very fine pieces $\left(0.1 \mathrm{~cm}^{2} / \mathrm{g}\right)$ and to be made airborne by the severity of the impact of aircraft parts, the metal would probably achieve self-sustained oxidation; a RARF would be applicable for ignited reactive metal in free-fall (1E-02). If the reactive metal is postulated to have completely oxidized during storage before the event, the RARF shown in point 9.b.3 (5E-02), is applicable.

(6) Deflagration (Rapid Burning of Flammable Mixture of Gas, with Reaction Completed in Milliseconds to Seconds: Blast Effects). The RARF is based on the value assumed for the suspension of powder from a hard unyielding surface due to the deflagration of a flammable gas mixture that fills less than $25 \%$ of the free volume directly over the unrestrained powder. The RARF may be limited by the fraction of the metal (or oxide powder if so postulated) that is present as particles in the respirable size range. The fraction of metal as particles in the respirable size range may be very small because metal in this form is very reactive because of the high surface-to-mass ratio. If finely divided metal (surface-to-mass ratio of $100 \mathrm{~cm}^{2} / \mathrm{g}$ ) were made airborne in the elevated-temperature atmosphere resulting from a deflagration, the fine particles would probably achieve selfsustained oxidation; the RARF for suspension from ignited drops of molten metal in free-fall ( $1 \mathrm{E}-02$ ) would be applicable to pieces of reactive metal in this size range.

(7) Detonation (Reaction Completed in Microseconds to Milliseconds: Shock Effects). The RARF is the sum of the RARFs for shock and blast effects. The RARF for the shock effects is based on a conservative interpretation of the Steindler and Seefeldt (1980) correlation that predicts the fragmentation of solids and liquids as a result of detonations on or in the material. The RARF is the mass of particles in the respirable size range suspended equal to the mass of the TNT equivalence predicted for the experiment. The RARF for the blast effects is given in point 9.a.6. 
(8) Pressurized Release (Venting of the Volume Holding the Reactive Metal That Has Been Slowly [ $>1 \mathrm{~min}$ ] Pressurized to $3.45 \mathrm{MPa}_{\mathrm{g}}[500 \mathrm{psig}]$ or less). (See point 9.b.3.)

\section{Noncombustible Aggregated Solids}

a. Spills (Free-Fall and Impact on a Hard, Unyielding Surface). Based on experiments where crush-impact forces were imposed on brittle materials (e.g., glass, sintered compacted ceramic oxide, cement, sandstone), an empirical model was formulated that predicts the particles in the respirable size range generated. (See Equation D.2.)

b. Crush-Impact (Crush or Impact from Contact with a Moving Object). The RARF is given in point 10.a.

c. Pressurized Release (Venting of the Volume Holding the Noncombustible Aggregated Solid That Has Been Rapidly [ $<1 \mathrm{~min}]$ Pressurized to $3.45 \mathrm{MPa}_{\mathrm{g}}$ [500 psig] or Less). No direct experimental data exist for the suspension of particles in the respirable size range from noncombustible aggregated solids. Large pieces would not be suspended by the accelerated gas velocities induced by the pressure release. Only the fine, powdery corrosion product (if any) on the surface of the solid would be subject to suspension, and this fraction may contain an appreciable fraction of the radionuclide inventory that usually exists as surface contamination. The most applicable RARF would be that postulated for the venting of dry ceramic powder under these conditions (5E-02). The material at risk, however, would be the fraction of the radionuclide inventory associated with the loose, powdery corrosion product on the surfaces of the noncombustible aggregated solid.

d. Small Fires (less than the entire inventory of radionuclides is involved, and the confinement capability of the facility is not impaired). Noncombustible aggregated solids such as concrete (grout) react under high temperature and oxidize with time to a loose powder (calcium oxide $[\mathrm{CaO}]$ ) that would increase the material at risk. Substantial oxidation is not anticipated for small fires. The RARF is based on the maximum experimental value for suspension of a dry ceramic powder heated on a hard unyielding surface in flowing air (6E-05).

e. Large Fires (almost the entire inventory of radionuclides is involved, and the confinement capability of the facility is damaged). Depending on the surface-to-volume ratio, a substantial fraction of the noncombustible aggregated solid and the radionuclides associated 
with the solid may oxidize during fires of long duration ( $>1 \mathrm{~h})$, thereby increasing the material at risk. The RARF is given in point 10.d.

f. Deflagration (Rapid Burning of Flammable Mixtures of Gas, with Reaction Completed in Milliseconds to Seconds: Blast Effects). The accelerated velocities induced by a deflagration would not suspend substantial pieces ( $>100 \mathrm{~g}$ [3.5 oz]) of noncombustible aggregated solids. Only the loose powdery material present on the surface of the solid exposed to the accelerated gas velocities would be affected. The RARF is based on the assumption that $1.0 \mathrm{E}-01$ of the powder is suspended by a deflagration of a flammable mixture of gas that fills less than $25 \%$ of the free volume directly over the unrestrained powder.

g. Detonation (Reaction Completed in Microseconds to Milliseconds: Shock Effects). The RARF is the sum of the shock and blast effects. The RARF for the shock effects is based on a conservative interpretation of the Steindler and Seefeldt (1980) correlation that predicts the fragmentation of solids or liquid from a detonation on or in the material. The RARF is the mass of material suspended as particles in the respirable size range equal to the mass of the TNT equivalence estimated for the explosion. The RARF for the blast effects is given in point $10 . f$.

h. Pressurized Release (Venting of the Volume Holding the Noncombustible Aggregated Solids That Have Been Slowly Pressurized to $3.45 \mathrm{MPa}_{\mathrm{g}}$ [500 psig] or Less). (See point 10.c.)

D.1.2.2.2 WM PEIS Waste RARFs for LLW Processing by Incineration. The RARFs for the waste categories and accident stresses anticipated during the incineration of LLW are tabulated in Table D.4 with the accompanying explanations.

D.1.2.2.3 WM PEIS Waste RARFs for HLW Processing and Storage. The RARFs for this waste category and the accident stresses during storage and processing of HLW (recovery and vitrification) are tabulated in Table D.5 with some additional clarification of the assumptions on which the values are based.

\section{D.2 LEAK PATH FACTORS}

\section{D.2.1 Background}

The LPF is defined as the fraction of material generated by the accident stress at the point of origin (RARF) that challenges the interface to the next volume. If the initial volume 
is the free volume of a container, the next volume could be an enclosure such as a glove box or hot cell. For these analyses, the next volume is the ambient environment; the initial volume is the exhaust system or operating area around the material. The implicit assumptions are that the waste form is contained or confined and that the initiating event breaches the initial barrier, thus releasing the airborne material suspended to the initial volume.

Facilities of various categories have varying degrees of air control systems ranging from none, to systems that direct the flow from areas of lesser contamination to areas of greater contamination by the use of negative pressure. The latter systems have single or multiple stages of filtration devices to attenuate the release of specific materials (e.g., particulate material, iodine). The directional flow systems may also filter both the enclosure or process exhaust and the operational-area or room exhaust. For the airborne materials of concern (nonvolatile particulate materials) in this study, the only filtration devices that are considered are HEPA filters.

\section{D.2.2 Technical Basis}

The filtration medium for a HEPA filter is a glass-fiber mat that collects particles challenging the medium through direct impaction (large-diameter particles that cross stream lines), interception (medium-diameter particles that deviate from the stream lines), and diffusion (submicron-sized particles that follow the stream lines but are collected in the pockets formed by the intersecting fibers). Particle collection depends on the aerodynamic size of the particle, the flow velocity, the fiber diameter, and leakage. The filter depends on multiple layers of packed fibers to provide the collection efficiency of the filter.

High-efficiency particulate air filters have approximately $18.6 \mathrm{~m}^{2}\left(200 \mathrm{ft}^{2}\right)$ of filter mat for a collection area. This expanse of filter medium is packed into a package $61-\mathrm{cm} \times$ $61-\mathrm{cm} \times \sim 30.5-\mathrm{cm}(2-\mathrm{ft} \times 2-\mathrm{ft} \times \sim 1-\mathrm{ft})$ deep by pleating the filter and separating the pleat using rigid separators at three locations across the filter folds. Air that enters the filter has momentum, and most of the filtration occurs at the face of the back folds, migrating back toward the face as the filter pores become filled or blocked by collected material. Thus, filters fail when the back fold is torn by impact from shock fronts exceeding the strength of the medium. Other accident environments may result in loss of function for the HEPA filters ranging from failure due to the temperature duration exceeding the strength of the mat, the chemical environment (e.g., hydrogen fluoride [HF]), static pressure, and blinding from the deposition of combustion products (i.e., soot and moisture) and (Bergman 1993). Conservative values for the potential failure pressure of HEPA filters due to various accident and environmental parameters taken from the report by Bergman (1993) are shown in Table D.6.

Normal environmental factors also have a deleterious effect. The filter medium is relatively (but not completely) free of organic binder and loses strength with age (Bergman 1993). Other factors, such as radiation, elevated temperature, chemical environment, and moisture may also result in loss of collection efficiency (Bergman 1993). Conservative values for the loss of collection efficiency due to various environmental conditions taken from the 
report by Bergman (1993) are tabulated in Table D.7. Recommended filter efficiencies for various types of systems extracted from Elder et al. (1986) are shown in Table D.8.

\section{D.2.3 Application to WM PEIS}

Because of the diversity of situations, conditions, equipment, and materials that may be present in waste handling, storage, and processing facilities, the LPFs that may be applicable are just as diverse. For the purpose of these analyses, the simplifying assumption was made that a functional exhaust system in a structurally sound structure will function as designed; air is drawn into the system and exhausted via the designed outlet. If the system is equipped with HEPA filters, the filters are assumed to be structurally sound, unless demonstrated by engineering calculations to be deteriorated by age or environmental conditions. A particle collection efficiency of $99.9 \%$ (transmission factor of $1 \mathrm{E}-03$ ) was assumed for the first bank, and a particle collection efficiency of $99.8 \%$ (transmission factor of 2E-03) was assumed for each subsequent bank. Bergman (1993) suggests that the particle collection efficiency of $99.9 \%$ (transmission factor of $1 \mathrm{E}-03$ ) be applied to each bank; but the standard is still in the review process, and the more conservative values are recommended. The damage thresholds listed in Table D. 6 can be used to evaluate the failure of HEPA filters under accident conditions.

Simplistic calculations have been performed to ascertain the failure of HEPA filters due to explosive events within facilities. The very conservative assumption was made that a HEPA filter of standard size $(61-\mathrm{cm} \times 61-\mathrm{cm} \times 30.5-\mathrm{cm}$ deep [2-ft $\times 2-\mathrm{ft} \times 1-\mathrm{ft}$ deep]) was at the system inlet from a room measuring $20 \mathrm{~m}(65.6 \mathrm{ft})$ long $\times 10 \mathrm{~m}(32.8 \mathrm{ft})$ wide $\times 5 \mathrm{~m}$ (16.4 ft) high with a functional exhaust system. A failure pressure of $1.5 \mathrm{psig}\left(0.00103 \mathrm{MPa}_{\mathrm{g}}\right)$ was assumed for the HEPA filter failure. The explosion was assumed to occur in the center of the room, and the minimum TNT equivalence necessary to result in the estimated HEPAfilter-failure pressure at the exhaust inlet was calculated. Under these very conservative assumptions, filter failure would not occur unless the TNT equivalence for a deflagration exceeded $7.7 \mathrm{~kg}\left(16.9 \mathrm{lb}_{\mathrm{m}}\right)$ and a detonation exceeded $5.8 \mathrm{~kg}(12.7 \mathrm{lb}$ ). These values may be used as a screening level when explosive events are considered for this study.

\section{D.3 MAPPING OF WM PEIS TREATABILITY CATEGORIES WITH PHYSICAL FORM CATEGORIES FOR ACCIDENT ANALYSIS}

The WM PEIS (DOE 1995) accident analysis assumes the application of a single accident physical form to approximate the actual physicochemical characteristics of the various treatability categories. A major assumption is that the release mechanism is assumed to be similar for all radionuclides within a given release class. This approach ignores the fact that the release fraction may, in general, be dependent on many variables, including the possible conversion into a less reactive form (as in the case of elemental iodine $\left[\mathrm{I}_{2}\right]$ reacting with cesium $[\mathrm{Cs}]$ to form cesium iodide [CsI], a much less volatile and more water-soluble form than iodine), the nature of the substrate, the form of contamination, and 
the characteristics of the container. This oversimplification is, however, necessary, given the lack of information concerning the physical and chemical characteristics of the various WM PEIS treatability categories.

The generic accident physical forms were developed on the basis of interaction with Science Applications International Corporation and review of the available information. Elder et al. (1986) divided the various radionuclides under a fire or explosive stress into four categories: (1) noble gases (e.g., krypton 85 [Kr-85]); (2) halogens; (3) volatile solids (Cs, rubidium [Rb], $\mathrm{Ru}$, tellurium [Te], technetium [Tc], and selenium [Se]); and (4) nonvolatile solids (including actinides and other fission products). Elder et al. (1986) stated that the release fractions for the various semivolatile radionuclides are to be reviewed on a case-by-case basis as a function of accident stress and conditions. Identical release fractions were applied to both volatile and nonvolatile solids by Elder et al. (1986). On the basis of this and other references (DOE-STD-3010-94, 1994), the categories of volatile solids and nonvolatile solids were combined into a single release class. In all cases, the assumption was that, on application of a given accident stress, all of the noble gases and halogens (including noncondensable gases) would be completely released (release fraction of unity). The mapping shown here applies only for the semivolatile and nonvolatile radionuclides.

Consideration of physical and chemical properties were used to match appropriate accident physical forms to the treatability categories. A matrix displaying waste characteristics was developed for the various WM PEIS waste types on the basis of available safety documentation and inventory characteristics. The mapping of the LLW treatability categories with the accident analysis physical forms shown in Table D.9 is, in general, based on the waste and process descriptions given by Feizollahi and Shropshire (1992) and by Goyette (1995). As shown in Table D.9, both the waste treatability category and the accident analysis physical form are assumed to be independent of site. Similar information for current storage of TRUW is presented in Table D.10.

More detailed information on process and waste characterization is available for HLW management, and therefore site- and process-specific physical forms were generated (Table D.11). Available safety documentation was used to ensure that the physicochemical characteristics for the dominant accident scenarios were considered. 
TABLE D.1 Summary of Release Fraction Parameters Abstracted from Elder et al. (1986)

\begin{tabular}{|c|c|c|c|}
\hline $\begin{array}{l}\text { Release Mechanism and } \\
\text { Safety Analysis Parameter }\end{array}$ & $\begin{array}{l}\text { Range of } \\
\text { Observation }\end{array}$ & $\begin{array}{l}\text { Current } \\
\text { Practice }\end{array}$ & $\begin{array}{l}\text { Recommended } \\
\text { Value }\end{array}$ \\
\hline Failed fuel-gap release $\mathrm{e}^{\mathrm{a}}$ & $0.015-0.34$ & $0.818-0.10$ & 0.10 \\
\hline Noble gas & b & 0.30 & 0.30 \\
\hline $\mathrm{K}-85$ & $0.025-0.49$ & $0.0032-0.10$ & 0.10 \\
\hline Halogens & - & 0.30 & 0.30 \\
\hline $\mathrm{I}-129$ & $<4.0 \mathrm{E}-06 \cdot 0.80$ & - & 0.01 \\
\hline $\begin{array}{l}\text { Volatile solids }(\mathrm{Cs}, \mathrm{Rb}, \mathrm{Ru}) \\
\text { Nonvolatile solids }\end{array}$ & $\begin{array}{c}<2.0 \mathrm{E}-06 \\
8.0 \mathrm{E}-04\end{array}$ & $<10.0 \mathrm{E}-6-0.05$ & 0.01 \\
\hline $\begin{array}{l}\text { Fire release } \\
\text { Noble gas } \\
\text { Halogens } \\
\text { Volatile solids } \\
\text { Nonvolatile solids } \\
\text { Fly ash } \\
\text { Airborne particle size }(\mu \mathrm{m})\end{array}$ & $\begin{array}{c}- \\
0.65-0.84 \\
3.0 \mathrm{E}-06-0.01 \\
4.0 \mathrm{E}-06-0.38 \\
5.0 \mathrm{E}-04-0.20 \\
<0.1-10\end{array}$ & $\begin{array}{c}0.90-1.00 \\
1.00 \\
0.01-0.90 \\
0.01-0.60 \\
0.01-0.05 \\
<5\end{array}$ & $\begin{array}{l}1.00 \\
1.00 \\
0.01 \\
0.01 \\
0.01 \\
<5\end{array}$ \\
\hline $\begin{array}{l}\text { Explosion } \\
\text { Noble gas } \\
\text { Halogens } \\
\text { Volatile solids } \\
\text { Nonvolatile solids } \\
\text { Airborne material } \\
\text { Airborne particle size ( } \mu \mathrm{m})\end{array}$ & $\begin{array}{c}\vdots \\
9.0 \mathrm{E}-05-0.14 \\
1.0-71 \mathrm{mg} / \mathrm{m}^{3} \\
-\end{array}$ & $\begin{array}{c}1.00 \\
1.00 \\
0.001 \\
0.01 \\
10-100 \mathrm{mg} / \mathrm{m}^{3} \\
<10-30\end{array}$ & $\begin{array}{c}1.00 \\
1.00 \\
0.01 \\
0.01 \\
100 \mathrm{mg} / \mathrm{m}^{3}, \\
<10\end{array}$ \\
\hline $\begin{array}{l}\text { Criticality } \\
\text { Initial pulse: fissions } \\
\text { Secondary pulse: fissions } \\
\text { Pulse interval } \\
\text { Total fissions } \\
\text { Total time } \\
\text { Gas release fraction } \\
\text { Halogen release fraction } \\
\text { Solid release fraction }\end{array}$ & $\begin{array}{l}3.0 \mathrm{E} 15-1.2 \mathrm{E} 20 \\
\text { No estimate } \\
\text { No estimate } \\
\text { No estimate } \\
\text { No estimate }\end{array}$ & $\begin{array}{c}\text { 1.0E18-1.0E20 } \\
7 \mathrm{~min}-24 \mathrm{~h} \\
1.00 \\
0.25-1.00 \\
0.001-0.20\end{array}$ & $\begin{array}{c}1.0 \times 10^{18} \\
1.9 \times 10^{17} \\
10 \mathrm{~min}\end{array}$ \\
\hline
\end{tabular}

a Fraction released, except as noted.

b A hyphen indicates data not available.

c Applicable to particulate material only.

d Includes release and plate-out.

- Use values from regulatory guides $3.33,3.34$, and 3.35 from the U.S. Nuclear Regulatory Commission (NRC 1977a, c, b). 
TABLE D.2 WM PEIS Waste RARFs: Physical Type or Subcategory versus Stress

\begin{tabular}{|c|c|c|c|c|c|c|c|c|c|}
\hline \multirow{3}{*}{\multicolumn{2}{|c|}{$\begin{array}{l}\text { Physical Form of Waste: } \\
\text { Waste Categories and Subcategory }\end{array}$}} & \multicolumn{8}{|c|}{ Stress } \\
\hline & & \multicolumn{3}{|c|}{ Mechanical Release } & \multicolumn{2}{|c|}{ Fire } & \multicolumn{3}{|c|}{ Explosive Release } \\
\hline & & $\begin{array}{l}\text { Free-Fall } \\
\text { Spill }\end{array}$ & Crush-Impact & $\begin{array}{c}\text { Over- } \\
\text { pressurization }\end{array}$ & Small & Large & Blast & Shock & $\begin{array}{c}\text { Venting High } \\
\text { Pressure }\end{array}$ \\
\hline 1. & Noncondensable gases" & $\mathrm{NA}^{\mathrm{b}}$ & NA & NA & NA & NA & $\mathrm{NA}$ & NA & NA \\
\hline 2. & 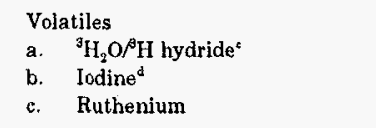 & $\begin{array}{l}\text { NA } \\
\text { NA } \\
\text { NA }\end{array}$ & $\begin{array}{l}\mathrm{NA} \\
\mathrm{NA} \\
\mathrm{NA}\end{array}$ & $\begin{array}{l}\mathrm{NA} \\
\mathrm{NA} \\
\mathrm{NA}\end{array}$ & $\begin{array}{r}\mathrm{NA} \\
\mathrm{NA} \\
1 \mathrm{E}-02\end{array}$ & $\begin{array}{r}\mathrm{NA} \\
\mathrm{NA} \\
1 \mathrm{E}-01\end{array}$ & $\begin{array}{l}\mathrm{NA} \\
\mathrm{NA} \\
\mathrm{NA}\end{array}$ & $\begin{array}{l}\mathrm{NA} \\
\mathrm{NA} \\
\mathrm{NA}\end{array}$ & $\begin{array}{l}\text { NA } \\
\text { NA } \\
\text { NA }\end{array}$ \\
\hline 3. & $\begin{array}{l}\text { Organic combustible liquids } \\
\text { a. Solutions }\end{array}$ & $2 \mathrm{E}-04$ & $2 \mathrm{E}-04$ & $1 \mathrm{E}-04$ & $1 \mathrm{E}+00\left({ }^{8} \mathrm{H}\right)$ & $\begin{array}{l}1 \mathrm{E}+00\left({ }^{9} \mathrm{H}\right) \\
1 \mathrm{E}-01\end{array}$ & $1 E-01$ & mass $=\mathrm{TNT} \mathrm{Eq}^{\circ}$ & $6 \mathrm{E}-04$ \\
\hline & b. Slurries & $4 E-05$ & $4 \mathrm{E}-05$ & $1 \mathrm{E}-04$ & $1 \mathrm{E}-02$ & $1 \mathrm{E}-01$ & 1E-01 & mass $=$ TNT Eq & $4 \mathrm{E}-04$ \\
\hline 4. & $\begin{array}{l}\text { Aqueous liquids } \\
\text { a. Solutions } \\
\text { b. Slurries } \\
\text { c. Superheated solutions }\end{array}$ & $\begin{array}{c}2 \mathrm{E}-04 \\
4 \mathrm{E}-05 \\
\mathrm{NA}\end{array}$ & $\begin{array}{l}2 \mathrm{E}-04 \\
4 \mathrm{E}-05 \\
\mathrm{NA}\end{array}$ & $\begin{array}{c}1 \mathrm{E}-04 \\
1 \mathrm{E}-04 \\
\mathrm{NA}\end{array}$ & $\begin{array}{c}2 E-03 \\
2 E-03 \\
N A\end{array}$ & $\begin{array}{r}2 \mathrm{E}-03 \\
2 \mathrm{E}-03 \\
\mathrm{NA}\end{array}$ & $\begin{array}{c}1 \mathrm{E}-04 \\
1 \mathrm{E}-04 \\
\mathrm{NA}\end{array}$ & $\begin{array}{c}\text { mass }=\text { TNT Eq } \\
\text { mass }=\text { TNT Eq } \\
\text { NA }\end{array}$ & $\begin{array}{c}6 \mathrm{E}-04 \\
6 \mathrm{E}-04 \\
\text { NA }\end{array}$ \\
\hline 5 . & $\begin{array}{l}\text { Powders } \\
\text { a. Combustible } \\
\text { b. Noncombustible }\end{array}$ & $\begin{array}{l}4 \mathrm{E} \sim 05 \\
6 \mathrm{E}-04\end{array}$ & $\begin{array}{l}4 \mathrm{E}-05 \\
3 \mathrm{E}-03\end{array}$ & $\begin{array}{l}1 \mathrm{E}-04 \\
2 \mathrm{E}-03\end{array}$ & $\begin{array}{l}1 \mathrm{E}-02 \\
1 \mathrm{E}-02\end{array}$ & $\begin{array}{l}1 \mathrm{E}-01 \\
1 \mathrm{E}-02\end{array}$ & $\begin{array}{l}1 \mathrm{E}-01 \\
7 \mathrm{E}-02\end{array}$ & $\begin{array}{l}\text { mass }=0.2 \mathrm{TNT} \mathrm{Eq} \\
\text { mass }=0.2 \mathrm{TNT} \mathrm{Eq}\end{array}$ & $\begin{array}{l}4 \mathrm{E}-04 \\
7 \mathrm{E}-02\end{array}$ \\
\hline 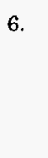 & $\begin{array}{l}\text { Combustible solids } \\
\text { a. DAW } \\
\text { b. Plastic (including elastomers) } \\
\text { c. Cellulosics } \\
\text { d. Polyethylene }\end{array}$ & $\begin{array}{l}1 \mathrm{E}-03 \\
1 \mathrm{E}-03 \\
1 \mathrm{E}-03 \\
1 \mathrm{E}-03\end{array}$ & $\begin{array}{l}1 \mathrm{E}-03 \\
1 \mathrm{E}-03 \\
1 \mathrm{E}-03 \\
1 \mathrm{E}-03\end{array}$ & $\begin{array}{l}1 \mathrm{E}-03 \\
1 \mathrm{E}-03 \\
1 \mathrm{E}-03 \\
1 \mathrm{E}-03\end{array}$ & $\begin{array}{l}5 \mathrm{E}-04 \\
1 \mathrm{E}-02 \\
1 \mathrm{E}-02 \\
1 \mathrm{E}-02\end{array}$ & $\begin{array}{l}4 \mathrm{E}-03 \\
5 \mathrm{E}-02 \\
1 \mathrm{E}-02 \\
1 \mathrm{E}-02\end{array}$ & $\begin{array}{l}5 E-04 \\
1 E-02 \\
1 E-02 \\
1 E-02\end{array}$ & $\begin{array}{l}\text { mass }=\mathrm{TNT} \mathrm{Eq} \\
\text { mass }=\mathrm{TNT} \mathrm{Eq} \\
\text { mass }=\mathrm{TNT} \mathrm{Eq} \\
\text { mass }=\mathrm{TNT} \mathrm{Eq}\end{array}$ & $\begin{array}{l}1 \mathrm{E}-03 \\
1 \mathrm{E}-03 \\
1 \mathrm{E}-03 \\
1 \mathrm{E}-03\end{array}$ \\
\hline 7. & Brittle solids (excluding SNF) & NA & $2 \mathrm{E}-11 \mathrm{pgh}^{\mathrm{j}}$ & $6 \mathrm{E}-07$ & $\mathrm{NA}$ & NA & $4 \mathrm{E}-05$ & mass $=\mathrm{TNT} \mathrm{Eq}_{\mathbf{q}}$ & $4 \mathrm{E}-05$ \\
\hline 8. & Viscous liquids (vitrified HLW) & $7 \mathrm{E}-09$ & $7 \mathrm{E}-09$ & $\mathrm{NA}$ & NA & NA & NA & mass $=$ TNT Eq & NA \\
\hline 9. & $\begin{array}{l}\text { Metals } \\
\text { a. Inert } \\
\text { b. Reactive }\end{array}$ & $\begin{array}{l}1 \mathrm{E}-03 \\
1 \mathrm{E}-03\end{array}$ & $\begin{array}{l}1 \mathrm{E}-03 \\
1 \mathrm{E}-03\end{array}$ & $\begin{array}{l}2 \mathrm{E}-03 \\
2 \mathrm{E}-03\end{array}$ & $\begin{array}{l}6 \mathrm{E}-05 \\
6 \mathrm{E}-04\end{array}$ & $\begin{array}{l}6 \mathrm{E}-05 \\
1 \mathrm{E}-02\end{array}$ & $\begin{array}{l}7 \mathrm{E}-02 \\
7 \mathrm{E}-02\end{array}$ & $\begin{array}{l}\text { mass }=\mathrm{TNT} E \mathrm{Eq} \\
\text { mass }=\mathrm{TNT} \mathrm{Eq}\end{array}$ & $\begin{array}{l}5 \mathrm{E}-02 \\
5 \mathrm{E}-02\end{array}$ \\
\hline 10. & Nonconbustible aggregate & $2 \mathrm{E}-11 \mathrm{pgh}$ & $2 \mathrm{E}-11 \rho \mathrm{gh}^{\mathrm{j}}$ & $2 \mathrm{E}-03$ & $\begin{array}{l}6 \mathrm{E}-05 \\
\left.1 \mathrm{E}+00 r^{8} \mathrm{H}\right) \\
\left(200^{\circ} \mathrm{C}\right)\end{array}$ & $\begin{array}{l}7 \mathrm{E}-02 \\
6 \mathrm{E}-03\left({ }^{3} \mathrm{H}\right) \\
\left(>600^{\circ} \mathrm{C}\right)\end{array}$ & NA & mass $=$ TNT Eq & $7 \mathrm{E}-02$ \\
\hline
\end{tabular}

Assume that all noncondensable gases are released if containment is lost.

$\mathrm{NA}=$ not applicable.

Assume that all ${ }^{3} \mathrm{H}_{8} \mathrm{O}$ or ${ }^{3} \mathrm{H}$ hydrides generated by local conditions are lost if containment is lost.

Assume that a fraction of the iodine generated by local conditions is released if containment is lost.

Mass $=$ trinitrotoluene $(\mathrm{TNT})$ equivalence $(\mathrm{Eq})$.

For $50 \cdot 100^{\circ} \mathrm{C}\left(122-212^{\circ} \mathrm{F}\right)$ superheating; $A R F=1.0 \mathrm{E}-00 \mathrm{~V} / R F$. . For $>100^{\circ} \mathrm{C}\left(>212^{\circ} \mathrm{F}\right), A R F=0.33[\mathrm{MF}]^{0.91}$

Use same RARF as for organic combustible liquid slurrie.

DAW $\approx$ dry active waste

A hyphen indicates data not availabte.

$\rho g h=$ densil $r$, gravitational accelaration $\left(980 \mathrm{~cm} / \mathrm{s}^{2}\right)$, and height of drop.

$\mathrm{HLW}=$ hign-level waste. 
TABLE D.3 WM PEIS Waste RARFs for LLW, LLMW, and TRUW Storage and Handling

\begin{tabular}{|c|c|c|c|c|c|c|c|c|c|}
\hline \multirow{3}{*}{\multicolumn{2}{|c|}{$\begin{array}{l}\text { Physical Form of Waste: } \\
\text { Waste Category }{ }^{(1)} \text { and Subcategory }\end{array}$}} & \multicolumn{8}{|c|}{ Stress } \\
\hline & & \multicolumn{3}{|c|}{ Mechanically Driven Release } & \multicolumn{2}{|c|}{ Fire } & \multicolumn{3}{|c|}{ Explosive Release } \\
\hline & & Free-Fall Spill & Crush-Impact & $\begin{array}{l}\text { Over- } \\
\text { pressurization }\end{array}$ & Small & Large & Blast & Shock & $\begin{array}{l}\text { Venting High } \\
\text { Pressure }\end{array}$ \\
\hline 1. & Noncondensable gases ${ }^{(2)}$ & (3) & (3) & (3) & (3) & (3) & (3) & (3) & (3) \\
\hline 2. & Volatiles $^{(4)}$ & (6) & (6) & (5) & $1 \mathrm{E}+0^{(6)}$ & (6) & (6) & (6) & (5) \\
\hline 3. & $\begin{array}{l}\text { Organic combustible liquids } \\
\text { a. Solutions } \\
\text { b. Slurries }\end{array}$ & $\begin{array}{l}2 \mathrm{E}-04^{(7)} \\
4 \mathrm{E}-5^{(7.16)}\end{array}$ & $\begin{array}{l}2 E-04^{(8,9)} \\
4 E-05^{(8,9)}\end{array}$ & $\begin{array}{l}1 \mathrm{E}-04^{(10)} \\
1 \mathrm{E}-04^{(10,16)}\end{array}$ & $\begin{array}{l}1 \mathrm{E}+0^{(11)} \\
1 \mathrm{E}-02 \\
6 \mathrm{E}-05^{(12)}\end{array}$ & $\begin{array}{l}1 E+0^{(11)} \\
1 E-01^{(12)} \\
6 E-05^{(6,12)}\end{array}$ & $\begin{array}{l}1 \mathrm{E}-01^{(13)} \\
1 \mathrm{E}-01^{(13,16)}\end{array}$ & (14) & $4 \mathrm{E}-04^{(16)}$ \\
\hline 4. & $\begin{array}{l}\text { Aqueous liquids } \\
\text { a. Solutions } \\
\text { b. Slurries } \\
\text { c. Superheated solutions }\end{array}$ & $\begin{array}{l}2 \mathrm{E}-04^{(7)} \\
4 \mathrm{E}-05^{(7,16)} \\
7 \mathrm{E}-02^{(17)}\end{array}$ & $\begin{array}{l}2 \mathrm{E}-04^{(8,9)} \\
4 \mathrm{E}-05^{8,9} \\
7 \mathrm{E}-02^{(17)}\end{array}$ & $\begin{array}{l}1 \mathrm{E}-04^{(10)} \\
1 \mathrm{E}-04^{(10,16)} \\
7 \mathrm{E}-02^{(17)}\end{array}$ & $\begin{array}{l}2 \mathrm{E}-03^{(1)} \\
2 \mathrm{E}-03^{(6)} \\
7 \mathrm{E}-02^{(17)}\end{array}$ & $\begin{array}{l}2 \mathrm{E}-03^{(16)} \\
2 \mathrm{E}-03^{(6)} \\
7 \mathrm{E}-02^{(17)}\end{array}$ & $\begin{array}{l}1 E-04^{(10)} \\
1 E-04^{(10,16)} \\
7 E-02^{(17)}\end{array}$ & $\begin{array}{l}(14) \\
(14) \\
(16,18)\end{array}$ & $\begin{array}{c}6 \mathrm{E}-04^{(15)} \\
6 \mathrm{E}-04^{(15)} \\
7 \mathrm{E}-02\end{array}$ \\
\hline 5. & $\begin{array}{l}\text { Powders } \\
\text { a. Combustibles } \\
\text { b. Noncombustible }\end{array}$ & $\begin{array}{l}4 E-05^{(7,16)} \\
6 \mathrm{E}-04^{(7,16)}\end{array}$ & $\begin{array}{l}4 \mathrm{E}-05^{(8,16)} \\
1 \mathrm{E}-02^{(8,16)}\end{array}$ & $\begin{array}{l}4 \mathrm{E}-05^{(16)} \\
5 \mathrm{E}-02^{(16)}\end{array}$ & $\begin{array}{l}6 \mathrm{E}-05^{(19)} \\
1 \mathrm{E}-02^{(16)}\end{array}$ & $\begin{array}{l}6 \mathrm{E}-05^{(19)} \\
1 \mathrm{E}-02^{(16)}\end{array}$ & $\begin{array}{l}6 \mathrm{E}-05^{(13,16)} \\
1 \mathrm{E}-01^{(16)}\end{array}$ & $\begin{array}{l}(14) \\
(14)\end{array}$ & $\begin{array}{l}4 \mathrm{E}-04^{(16)} \\
7 \mathrm{E}-02^{(16)}\end{array}$ \\
\hline 6. & $\begin{array}{l}\text { Combuatible solida } \\
\text { a. DAW } \\
\text { b. Plastic (including elastomers) } \\
\text { c. Cellulosics } \\
\text { d. Polyethylene }\end{array}$ & $\begin{array}{l}1 E-03^{(20)} \\
1 E-03^{(20)} \\
1 E-03^{(20)} \\
1 E-03^{(20)}\end{array}$ & $\begin{array}{l}1 E-03^{(20)} \\
1 E-03^{(20)} \\
1 E-03^{(20)} \\
1 E-03^{(20)}\end{array}$ & $\begin{array}{l}1 \mathrm{E}-03^{(20)} \\
1 \mathrm{E}-03^{(20)} \\
1 \mathrm{E}-03^{(20)} \\
1 \mathrm{E}-03^{(20)}\end{array}$ & $\begin{array}{l}5 \mathrm{E}-04^{(21)} \\
1 \mathrm{E}-02^{(24)} \\
1 \mathrm{E}-02^{(24)} \\
1 \mathrm{E}-02^{(24)}\end{array}$ & $\begin{array}{l}4 \mathrm{E}-03^{(22)} \\
6 \mathrm{E}-02^{(24)} \\
1 \mathrm{E}-02^{(22)} \\
1 \mathrm{E}-02^{(24)}\end{array}$ & $\begin{array}{l}6 \mathrm{E}-04^{(23)} \\
1 \mathrm{E}-02^{(23)} \\
1 \mathrm{E}-02^{(23)} \\
1 \mathrm{E}-02^{(23)}\end{array}$ & $\begin{array}{l}(14) \\
(14) \\
(14) \\
(14)\end{array}$ & $\begin{array}{l}1 \mathrm{E}-03^{(20)} \\
1 \mathrm{E}-08^{(20)} \\
1 \mathrm{E}-03^{(20)} \\
1 \mathrm{E}-03^{(20)}\end{array}$ \\
\hline 7. & Brittle solids (excluding SNF) & (3) & (3) & (3) & (3) & (3) & (3) & (3) & (3) \\
\hline 8. & Viscous liquids (vitrified HLW) & (3) & (3) & (8) & (3) & (3) & (3) & (a) & (3) \\
\hline 9. & $\begin{array}{l}\text { Metals } \\
\text { a. Inert } \\
\text { b. Reactive }\end{array}$ & $\begin{array}{l}1 \mathrm{E}-03^{(20,25)} \\
1 \mathrm{E}-03^{(20,25)}\end{array}$ & $\begin{array}{l}1 \mathrm{E}-03^{(20,25)} \\
1 \mathrm{E}-03^{(20,25)}\end{array}$ & $\begin{array}{l}2 \mathrm{E}-03^{(25)} \\
2 \mathrm{E}-03^{(25)}\end{array}$ & $\begin{array}{l}6 \mathrm{E}-05^{(25,26)} \\
3 \mathrm{E}-04^{(27)}\end{array}$ & $\begin{array}{l}6 E-05^{(25,28)} \\
1 E-02^{(27)}\end{array}$ & $\begin{array}{l}7 E-02^{(26)} \\
7 E-02^{(25)}\end{array}$ & $\begin{array}{l}\text { (14) } \\
\text { (14) }\end{array}$ & $\begin{array}{l}5 \mathrm{E}-02^{(25)} \\
5 \mathrm{E}-02^{(25)}\end{array}$ \\
\hline & Noncombustible aggregate & $2 \mathrm{E}-11 \rho \mathrm{\rho gh}^{(28)}$ & $2 E-11 \rho g h^{(28)}$ & $2 \mathrm{E}-08^{(16,25)}$ & $6 \mathrm{E}-05^{(16,25)}$ & $6 \mathrm{E}-05^{(16,25)}$ & $7 \mathrm{E}-02^{(16,25)}$ & (14) & $7 \mathrm{E}-02^{(29)}$ \\
\hline
\end{tabular}


TABLE D.3 (Cont.)

(1) Physical forms are as defined in Section 5 with the exceptions and additions noted in the following footnotes.

(2) For noncondensable gases, the RARF is not applicable. Noncondensable gases are not anticipated for LLW. Radionuclides as noncondensable gases are found in SNFs, accumulated in special off-gas components from the processing of SNF, or generated during inadvertent nuclear criticalities. The SNFs are not LLW, nor is the equipment associated with the processing of SNF. Inadvertent nuclear criticalities are not a credible event for LLW.

(3) Not anticipated.

(4) Volatile radionuclides (such as ${ }^{3} \mathrm{H}$, iodine, or $\mathrm{Ru}$ ) are assumed to be dissolved in a liquid or occur as a solid compound and require special physicochemical conditions to be generated as a vapor. Only ${ }^{3} \mathrm{H}$ in the form of ${ }^{3} \mathrm{H}_{2} \mathrm{O}$ or of ${ }^{3} \mathrm{H}$ hydrides is assumed to be volatilized by heat alone and is assigned a RARF of $1 \mathrm{E}$ under thermal stress. All other volatiles (such as iodine or $\mathrm{Ru}$ require additional chemical environments (acidic solutions and oxidants) and behave as nonvolatiles. The RARF for the dissolved iodine during the burning of an organic combustible liquid is assumed to be 1.0 .

(5) Use the RARF for the appropriate physical form

(6) Tritium as ${ }^{3} \mathrm{H}_{2} \mathrm{O}$ or ${ }^{3} \mathrm{H}$ hydrides.

(7) Free-fall distances up to $3 \mathrm{~m}(10 \mathrm{ft})$

(8) The RARF is based on a conservative interpretation of the experimental data for the suspension of uncontained loose powder from a stiff, flexible nonporous surface by the impact of hard objects after free-fall.

(9) The RARF is based on the suspension of particles in the respirable size range by the impact of a foreign object on uncontained loose powder on a stiff, flexible nonporous surface.

(10) The RARF for the venting of rapidly ( $<1 \mathrm{~min}$ ) pressurized volumes (gas does not have time to absorb into a liquid) to a pressure of $1.38 \mathrm{MPa}$ (200 psig) through an opening equivalent in size to an orifice with a diameter of $1 \mathrm{~mm}(0.04 \mathrm{in}$.) or greater near the bottom of the sidewall of the container. The RARF is not applicable to very fine $(<0.1-\mathrm{mm}[<0.04$-in.] width) slot-type openings.

(11) Iodine.

(12) Assumes the organic combustible liquid is burned to complete dryness (no liquid or moist residue).

(13) Deflagrations are assumed to generate drops of liquid both by shear stress (RARF of $4 \mathrm{E}-03 / \mathrm{h}$ for 1 min [duration of passage of pressure impulse] $=7 \mathrm{E}-05$ ) and during the burning of the organic combustible liquid ignited by the passage of the flame front. The RARF for the event is dominated by the RARF for the burning of the organic combustible liquid to complete dryness (1E-01).

(14) Detonation must occur on or in the material of concern. The RARF is based on a conservative interpretation of the Steindler and Seefeldt (1980) correlation (fragmentation and suspension due to shock effect) and the suspension due to passage of the gases generated by the detonation (blast effect, shear stress) without ignition of the organic combustible liquid. The RARF for shock effect is the mass of the particles in the respirable size range airborne equal to the mass of TNT equivalence estimated for the explosion.

(15) The RARF is for the venting of a slowly ( $>1 \mathrm{~min}$ ) pressurized volume (pressurizing gas can be absorbed into the liquid; initial pressure up to (3.45 $\mathrm{MPa} \mathrm{a}_{\mathrm{g}}[500$ psig]) through an opening near the surface of the liquid or at the bottom of the sidewall of the vessel or container. 
(16) The amount of particles suspended may be limited by the amount of particles in the respirable size range present in the source.

(17) Aqueous liquids superheated to $50-100^{\circ} \mathrm{C}\left(122-212^{\circ} \mathrm{F}\right)$ above the boiling point of the solvent (water).

(16) The RARF for this event is the greater of the RARF for shock effect (mass of particles in the respirable size range airborne equal to the mass of TNT equivalence estimated for the explosion) or the RARF for pressurized release (7E-02).

(19) See organic combustible liquid slurries.

(20) Solid contamination jarred from the surface of the material by impact with a hard unyielding surface. The RARF for this stress is assumed to be bounded by the RARF for the impact of objects on uncontained powder lying on a stiff, flexible nonporous surface after free-fall.

(21) The DAWs are defined as contaminated combustible solids in an uncontaminated combustible wrapping (usually plastic). The RARF applies to the suspension of particles in the respirable size range during the burning of the packages of wrapped waste.

(22) The RARF is based on the assumption that the contaminated combustible material burns while suspended in air due to the force of impact of aircraft components with the package.

(28) The RARF is for suspension of particles in the respirable size range during the burning of the contaminated combustible materials ignited by the passage of the flame front resulting from the deflagration that dominates the RARF for the suspension of particles in the respirable size range by vibration (1E-03).

(24) The RARF applies to the suspension of particles in the respirable size range during the burning of uncontained, contaminated, combustible solids (the contaminated surface is exposed to the atmosphere before burning).

(25) The material at risk is the loose, powdery corrosion product present in the package or on the surface of the object.

(26) Based on the RARF for the heating of a nonreactive powder on a hard unyielding surface.

(27) The RARF is based on the suspension of particles in the respirable size range during the complete oxidation of large pieces of uranium metal.

(28) The RARF is the mass of particles in the respirable size range formed and suspended by the impact of the physical form with a hard unyielding surface after free-fall or by the impact of a foreign body on the physical form after free-fall and is estimated by the following:

$R A R F=(A)(D)(g)(h)$, where $A=$ empirical correlation factor $(2 \mathrm{E}-11), D=$ density $\left(\mathrm{g} / \mathrm{cm}^{3}\right), g=$ gravitational acceleration $\left(980 \mathrm{~cm} / \mathrm{s}^{2}\left[32 \mathrm{ft} / \mathrm{s}^{2}\right]\right)$ and $h=$ height of fall $(\mathrm{cm})$

If the RARF is applied to foreign objects impacting the physical form, the damage ratio is the fraction of the total surface area impacted by the object.

(29) The RARF for fragmentation of brittle solids due to free-fall or for the impact of foreign objects on the surface of brittle solids after free-fall is as follows: $R A R F=$ $[A][D][g][h]$, where $A=$ empirical correlation coefficient $(2 \mathrm{E}-11), D=$ density of the falling material $\left(\mathrm{g} / \mathrm{cm}^{3}\right), g=$ acceleration due to gravity $\left(980 \mathrm{~cm} / \mathrm{s}^{2}\left[32 \mathrm{ft} / \mathrm{s}^{2}\right]\right)$ and $h=$ distance of fall $(\mathrm{cm})$. If the correlation is applied to the impact of a foreign object on brittle solids, the damage ratio should be adjusted to correspond to the fraction of the impact area to the total surface area available. 
TABLE D.4 WM PEIS Waste RARFs for LLW Processing by Incineration

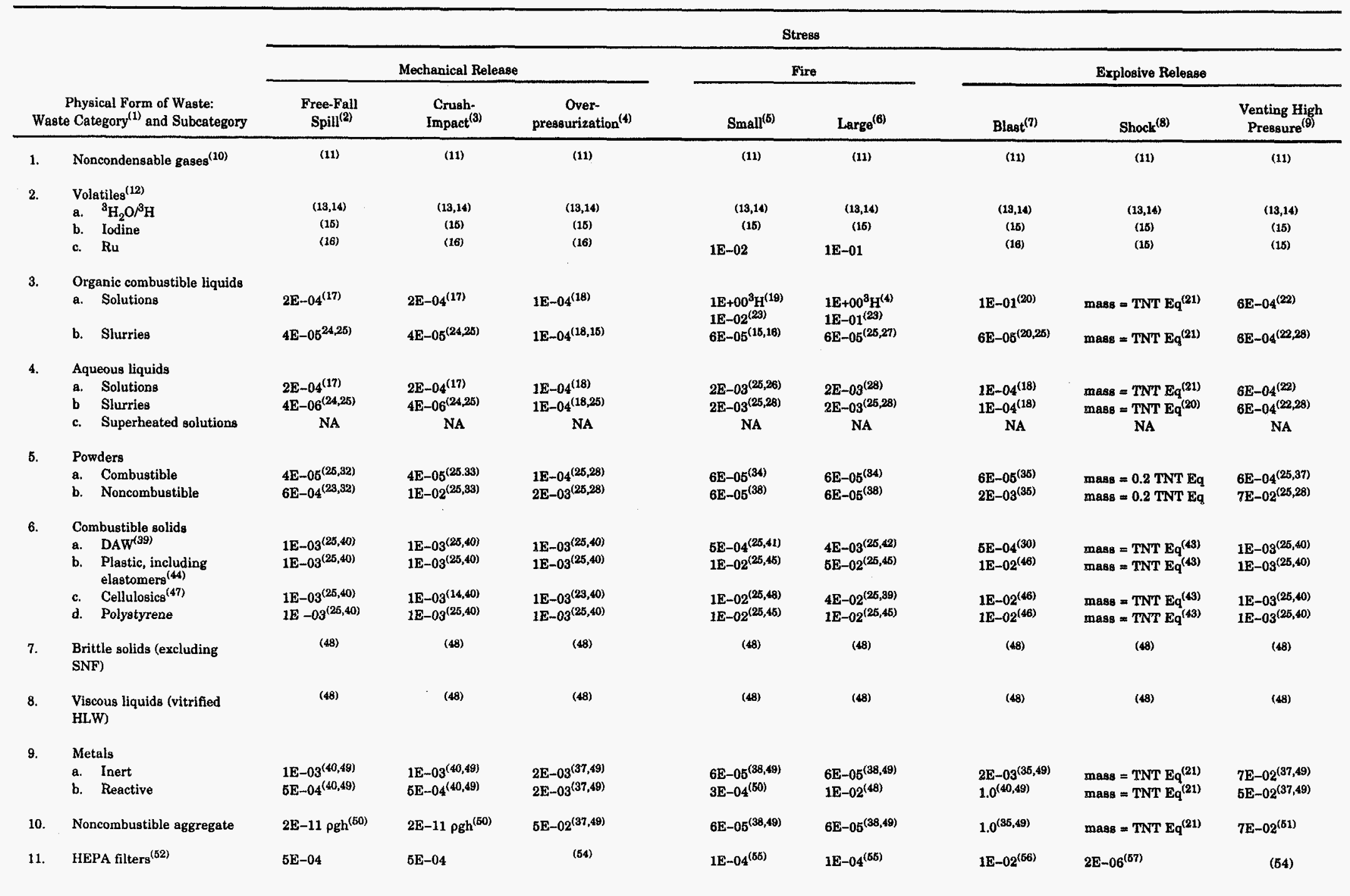


(1) The physical forms are as defined in Mueller's (1994) fax to Mishima, with the exceptions and additions as noted in the following footnotes.

(2) The stress postulated is for the free-fall spill of the physical form a distance of $3 \mathrm{~m}(10 \mathrm{ft})$ or less and for the impact on a hard unyielding surface.

(3) Crush-impact assumes that the RARF for crushing of the physical form is bounded by the RARF for impact of the physical form by an object.

(4) The venting of a rapidly ( $<1 \mathrm{~min}$ ) pressurized volume (up to a pressure of $1.38 \mathrm{MPa}_{\mathrm{g}}$ [200 psigl) containing the physical form is postulated. The RARF does not assume that the pressurizing gases are absorbed into a liquid and can effervesce on depressurization.

(5) For a small fire, assume that less than the entire inventory of material is involved in the fire and that the structural containment is not compromised

(6) For a large fire, assume that close to the entire inventory of radionuclides is involved and that the structural containment is damaged. An example of a large fire is the fire resulting from the impact of an aircraft on the structure containing the LLW.

(7) Deflagration (blast effect). Deflagrations are the rapid (within minutes) burning of a flammable gas mixture (air and fuel) that fills most (greater than $25 \%$ ) of the volume of an equipment component or package. It is assumed that the pressure generated is adequate to defeat containment and that other components of an off-gas system may be impacted, depending on the gas pressures generated, the design of the component, and the distance of the component from the deflagration.

(8) For detonation (shock effect), the RARF is based on a conservative interpretation of the Steindler and Seefeldt (1980) correlation for the fragmentation by condensed-phase explosion in or an metals or aqueous solutions: the mass of particles in the respirable size range suspended by detonations on or in metal and aqueous solution is equal to the mass of TNT equivalency (Eq) estimated for the explosion.

(9) For pressurized release, the RARF is for the venting of a slowly ( $>1 \mathrm{~min}$ ) pressurized volume (at a pressure to $3.45 \mathrm{MPa}_{\mathrm{g}}[500$ psig]) containing the physical form.

(10) The presence of noncondensable gases is not anticipated in LLW, and, therefore, RARFs for the physical form are not applicable. Noncondensable gases must be contained or generated. Noncondensable gases are found in SNF (not a LLW form), collected in special off-gas equipment, or generated in inadvertent nuclear criticalities that are not a credible scenario for LLW.

(11) Assume all noncondensable gases are released if containment is lost.

(12) Use the RARF designated for the appropriate physical form under this stress.

(13) Assume that all ${ }^{3} \mathrm{H}_{2} \mathrm{O}$ and ${ }^{3} \mathrm{H}$ hydrides generated by local conditions are released if containment is lost.

(14) Applies to ${ }^{3} \mathrm{H}$ in the form of water or hydrides only.

(15) Assume that the fraction of iodine generated by local conditions is released if containment is lost.

(16) Not applicable.

(17) Based on the RARF for the suspension of particles in the respirable size range from impact on a hard unyielding surface for aqueous solutions after a free-fall of $3 \mathrm{~m}$ (10 $\mathrm{ft}$ ) or less.

(18) Based on the RARF for the venting of an aqueous solution from an opening at the bottom of the sidewall of the vessel or container equivalent to an orifice with a diameter of greater than $1 \mathrm{~mm}$ for an initial pressure of $1.38 \mathrm{MPa}_{\mathrm{g}}(200 \mathrm{psig})$ or less. The RARF does not apply to venting via very fine $(<0.1-\mathrm{mm}$ width $)$ slot-type openings.

(19) The RARF applies to iodine dissolved in the liquid only. All other materials are assumed to behave as nonvolatiles, and the RARF for nonvolatile materials applies.

(20) Assume that the combustible liquid is ignited by the passage of the flame front and that the RARF is based on the suspension of nonvolatile materials dissolved in the liquid.

(21) Assume a detonation on or in the material of concern. The RARF is based on a conservative interpretation of the fragmentation and suspension of aqueous liquids predicted by the Steindler and Seefeldt (1980) correlation: the mass of particles in the respirable size range airborne is equal to the mass of the TNT Eq estimated for the explosion.

(22) The RARF is based on the suspension of particles in the respirable size range during the venting of a volume containing an aqueous solution near or below the liquid surface after slow ( $>1 \mathrm{~min}$ ) pressurization of the volume. The assumption is that behavior of organic combustible liquid is sufficiently similar to that of aqueous liquids for the purposes of these analyses.

(23) The $\mathrm{RAR}_{1}^{\prime}$ for nonvolatile materials is assumed to apply to all other materials.

(24) Based on the RARF for the fragmentation and suspension of aqueous slurries on impact with a hard unyielding surface after a free-fall of $3 \mathrm{~m}$ (10 $\mathrm{ft}$ ) or less. The assumption is that the behavior of organic combustible liquids is sufficiently similar for the purposes of these analyses.

(25) If the radionuclides are associated with the nonreactive particles, the RARF can be limited by the particles in the respirable size range present in the source material.

(26) Based on the RARF for nonvolatile materials dissolved in the organic combustible liquid during burning under conditions that leave a residue of liquid or.sludge. For radionuclides associated with the nonreactive particles in the slurries, the RARF for noncombustible powders under thermal stress (6E-05) is applied and may be further limited by the particles in the respirable size range in the particle fraction of the slurry.

(27) Based on the RARF for nonvolatiles dissolved in the liquid during burning of the organic combustible liquid to complete dryness. For radionuclides associated with the nonreactive particle component of slurries, a RARF of $6 \mathrm{E}-05$ is applied and is limited by the fraction of particles in the respirable size range in the nonreactive particles originally present.

(28) The RARF is for the suspension of drops in the respirable size range by boiling of aqueous solutions and bounds the RARF for lesser levels of thermal stress (evaporation). The RARF does not apply to suspension from aqueous liquids under the churn-turbulent or chaotic boiling regimes.

(29) For $50-100^{\circ} \mathrm{C}\left(122-212^{\circ} \mathrm{F}\right)$ superheat, $A R F=1 \mathrm{E}-01 / R F 0.7$. For $>100^{\circ} \mathrm{C}\left(212^{\circ} \mathrm{F}\right), A R F=0.33[M F]^{0.91}$

(30) Assumes containment is lost due to the stress. The RARF applies to the suspension of drops in the respirable size fraction from the venting of aqueous solutions superheated to $51^{\prime} 30^{\circ} \mathrm{C}\left(122-212^{\circ}\right.$ : above the boiling point of water from an rpening near or un. ' he surface lev ${ }^{\circ}$ of the liquid. 
(31) Assumes a detonation on or in the superheated aqueous solution, resulting in the loss of containment. The RARF is the sum of the RARFs for the shock (mass of particles in the respirable size range equal to the mass of TNT Eq of the explosion) and for the venting of the superheated aqueous solution (1E-01).

(32) The RARF is for the suspension of a dry ceramic powder on impact with a hard unyielding surface after a fall of $3 \mathrm{~m}(10 \mathrm{ft})$ or less.

(33) The RARF is based on the RARF for suspension of particles in the respirable size range by the impact of large objects on uncontained powders on a stiff nonporaus surface.

(34) If the radionuclides are dissolved in the organic combustible phase, the RARF listed for organic combustible liquids under thermal stress, above, is applied. If the radionuclides are associated with the nonreactive powder component of the slurry, the RARF for the powders, noncombustible, below, apply.

(35) Assumes a deflagration of a flammable gas mixture that fills greater than $25 \%$ of the volume of the vessel or equipment or package directly over the exposed powder and causes failure of the containment.

(36) Detonation in or on the exposed powder of a severity sufficient to cause the containment to fail. The RARF is a sum of the RARFs for shock (mass of particles in the respirable size range airborne equal to the mass of the TNT Eq of the explosion) and blast (1.0E). Because the RARF for the blast is 1.0E, the RARF for this stress cannot exceed 1.0E.

(37) Based on the suspension of a dry ceramic powder during venting of a volume pressurized to $3.45 \mathrm{MPa}_{8}(500 \mathrm{psig}$ ) and less.

(38) The RARF is for the suspension of respirable particles in the respirable size range from a dry, ceramic nonreactive powder under thermal stress.

(39) DAW = dry active waste (contaminated combustible trash wrapped in uncontaminated thin combustible wrapping).

(40) The RARF for surface contamination suspended by vibration or impact of objects on the surface of the physical form without fragmentation of the substrate. For impact of foreign objects, the damage ratio may be adjusted to compensate for the fraction of the surface area affected by the object (assume twice the impact area of the object).

(41) The RARF for the suspension of particles in the respirable size range during the burning of contained (wrapped), contaminated combustible materials.

(42) The RARF for the suspension of particles in the respirable size range by air passing through the mass during the burning of uncontained, contaminated, combustible cellulosic material. This scenario assumes that the DAW is unwrapped by the severity of the impact of aircraft parts on the container and that the cellulosic material is suspended in air during the burning.

(43) The RARF for this scenario is the sum of the RARFs for shock (mass of particles in the respirable size range made airborne is equal to the mass of the TNT Eq estimated for the explosion) and blast (suspension of particles in the respirable size range by vibration [1E-03]) effects.

(44) Plastic = all uncontained, contaminated, combustible plastic and elastomer materials except polystyrene.

(45) The RARF is the value for the suspension of particles in the respirable size range from the burning of the uncontained, contaminated physical form

(46) Scenario assumes that the deflagration disperses and ignites the DAW. The RARF is based on the burning of contained, contaminated combustible material.

(47) Cellulasics = all cellulose-based trash (e.g., wood, paper, rags, cardboard)

(48) Cellulasics = all

(49) The RARF applies to the loose, powder corrosion product present in the package and on the surface of the physical form. The contamination is assumed to be uniformly distributed over the entire surface of the physical form.

(50) The RARF is based on the suspension of particles in the respirable size range suspended during the oxidation of bulk pieces of uranium metal and bounds the release anticipated during the self-sustained oxidation of large pieces of Pu metal.

(51) The RARF is the mass of particles in the respirable size range formed and suspended by the impact of the physical form with a hard unyielding surface after free-fall or by the impact of a foreign body on the physical form after free-fall and is estimated by the following:

$R A R F=(A)(D)(g)(h)$, where: $A=$ empirical correlation factor $(2.11 \mathrm{E}-04), D=$ density $\left(\mathrm{g} / \mathrm{cm}^{3}\right), \mathrm{g}=$ gravitational acceleration $\left(980 \mathrm{~cm} / \mathrm{s}^{2}\left[32 \mathrm{ft} / \mathrm{s}^{2}\right]\right)$, and $h=\mathrm{height}$ of fall (cm).

If the RARF is applied to foreign objects impacting the physical form, the damage ratio is 2 times the fraction of the total surface area impacted by the object.

(52) A $61-\mathrm{cm} \times 61-\mathrm{cm} \times 30.5-\mathrm{cm}$ deep $(2-\mathrm{ft} \times 2-\mathrm{ft} \times 1-\mathrm{ft}$ deep), pleated, glass-fiber HEPA filter. Filters of other configurations and designs may exhibit substantially different behavior under the stated stresses, and the values listed for the RARF may not apply.

(53) The RARF is applied to the suspension of particles in the respirable size range accumulated in a $61-\mathrm{cm} \times 61-\mathrm{cm} \times 30.5$-cm deep (2-ft $\times 2$-ft $\times 1$-ft deep) HEPA filter on impact with a hard unyielding surface after free-fall through an appreciable distance ( $\leq 3 \mathrm{~m}[\leq 10 \mathrm{ft})$ ). The HEPA filter is not contained in a package or housing. The RARF for the same situation for HEPA filters contained in a package or housing is $5 \mathrm{E}-04$.

54) No significant release of the inventory accumulated in a HEPA filter is postulated for the passage of gas at an accelerated velocity through the filter. The filters are designed for gas passage through the filter and would not release their accumulated inventory by the simple passage of gas through the filter. If any material is released by reverse flow through the filter, the material is released into the contained volume.

(55) The RARF is for the suspension of particles in the respirable size range by the passage of gas heated to a temperature below the failure temperature of the glass-fiber collection medium. Failure of the medium is by melting and is not postulated to release the accumulated inventory.

(56) The RARF is for the release of particles in the respirable size range from the accumulated inventory due to the failure of the filter collection medium by static or slow buildup of pressure.

(57) The RARF is for the release of particles in the respirable size range from the accumulated inventory due to the failure of the HEPA filter medium from a shock front. 


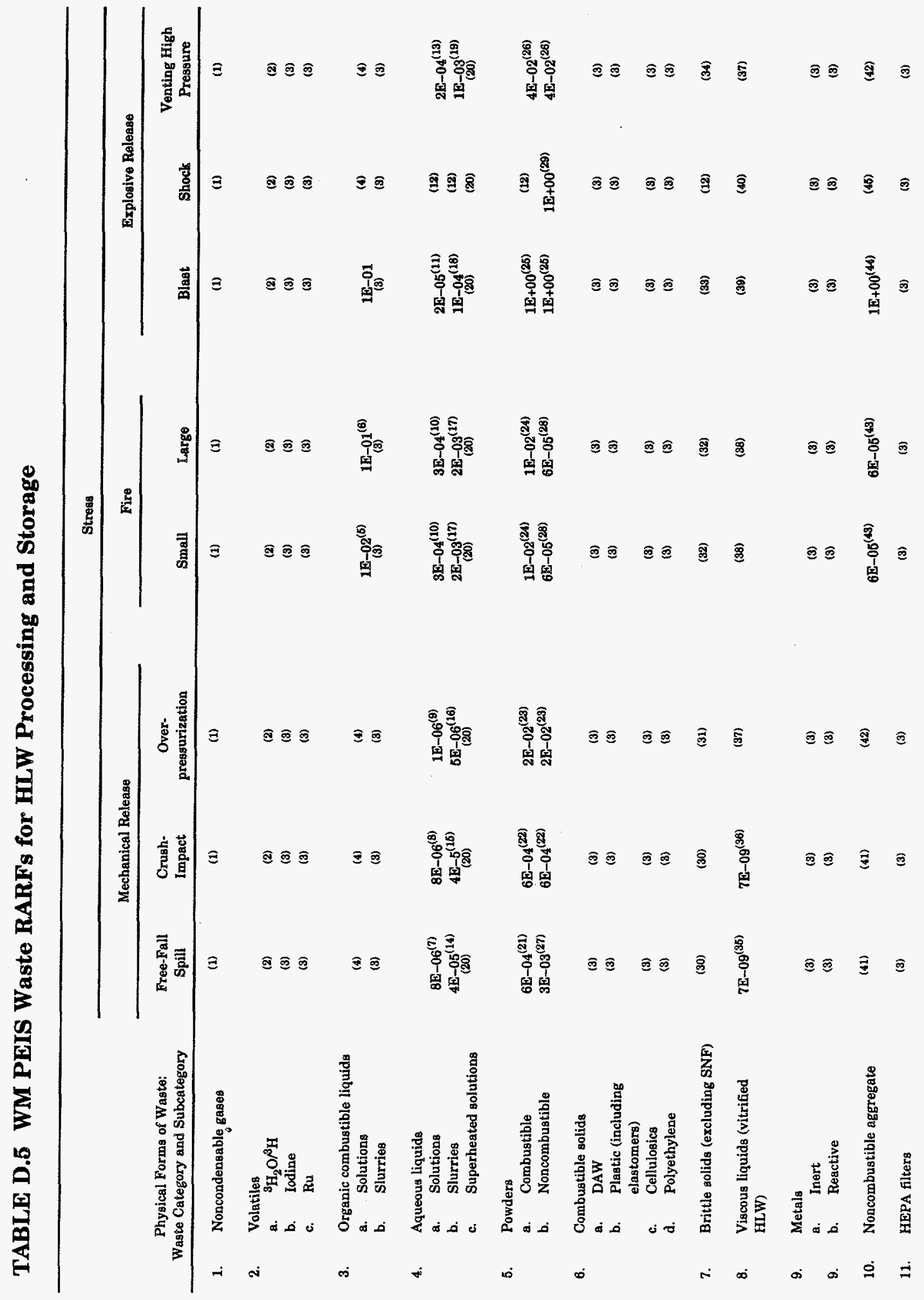


(1) Assume that all noncondensable gases are released if containment is lost.

(2) Assume that all ${ }^{3} \mathrm{H}_{2} \mathrm{O}$ and ${ }^{3} \mathrm{H}$ hydrides generated by local conditions are released if containment is lost.

(3) Not anticipated.

(4) Use value for aqueous liquids, solutions (subcategory 4.a), for this stress.

(5) Assume that the organic combustible liquids burn, but the intensity of a small fire is not adequate to burn all of the liquid to complete dryness.

(6) Assume that all of the organic combustible liquid is burned to complete dryness.

(7) For free-fall spill of aqueous liquids solution. Assume that the vessel containing the liquid is elevated above a hard unyielding floor and fails near the bottom of the sidewall so that almost all of the liquid falls to the floor. Experimental results reported by Ballinger and Hodgson (1986) show that the ARF decreases with increasing viscosity or specific gravity $(\mathrm{SpG})$. In the range of viscosity of $1-50 \mathrm{cp}$, the relationship appears linear. The SpGs of the viscous liquids used in the experiments was in the range of 1.102-1.277, on the lower end of the range of SpGs of liquid HLW. The maximum measured RARF for this range was $8 \mathrm{E}-\mathbf{0 6}$ and appears to be very conservative for this material.

(8) Assume that the impact of an object with liquid HLW is equivalent to the impact on a hard unyielding surface of liquid HLW after free-fall and that the RARF for free-fall applies.

(9) Assume that the impact of an object into the liquid is as efficient at suspension of droplets in the respirable size range as the impact of the liquid on a hard unyielding surface after a free-fall of $3 \mathrm{~m}(10 \mathrm{ft})$

(10) Assume that the reduction in RARF during the boiling of an aqueous viscous solution is proportional to the reduction of RARF between free-fall of an aqueous solution and freefall of an aqueous viscous solution $(0.144)(2 \mathrm{E}-03 \times 0.144=2.9 \mathrm{E}-04$ or $\sim 3 \mathrm{E}-04)$.

(11) It is assumed that the viscous aqueous solution is vented via a crack or opening at or near the bottom of the sidewall of the vessel holding the liquid (the RARF for underground liquid HLW storage tanks is discussed subsequently); a comparable reduction in the RARF shown in free-fall spills (0.144) also applies. The RARF for this case is

$1 \mathrm{E}-04 \times 0.144=1.44 \mathrm{E}-05$ or conservatively rounded upward to $2 \mathrm{E}-05$. Venting of the pressure resulting from a deflagration via an opening well above the liquid level (as is the case for the failure of an underground liquid storage tank) would depend on the energy generated (affects the pressure and failure of the vessel), the size and location of the opening (affects the velocity, turbulence, and direction of flow in the free volume of the vessel), and the characteristics of the material (high viscosity decreases the formation of drops). No data are known on the RARF for this type of material. The RARF is certainly less than that for the venting of a pressurized liquid when the gas is absorbed in the liquid (2E-03). Calculations that use very conservative parameters in the SPRAYMASS model (Roblyer and Owczarski 1992), which were modified for the higher viscosity of alkaline liquid $\mathrm{HLW}$, indicate a value of $6 \mathrm{E}-05$.

(12) The mass of particles in the respirable size range made airborne by a detonation is equal to the mass of the TNT equivalence (Eq) of the explosion.

(13) Assumes the reduction in RARF for the venting of an aqueous viscous solution is in the same ratio as the reduction in RARF as a result of the free-fall of $3 \mathrm{~m}$ (10 $\mathrm{ft}$ ) between an aqueous solution and an aqueous viscous solution.

(14) Maximum RARF measured for the 3-m (10-ft) free-fall spill of slurries of Ballinger and Hodgson (1986).

(15) Assumes the impact of an object on the slurry has the same or less effect on suspension of the slurry as the impact of the slurry on a hard unyielding surface after a free-fall of $3 \mathrm{~m}(10 \mathrm{ft})$.

(16) Assume that the reduction in RARF for the venting of a slurry pressurized to $50 \mathrm{psig}\left(0.34 \mathrm{MPa}_{\mathrm{g}}\right)$ is proportional to the reduction in RARF between an aqueous solution and an aqueous viscous solution.

(17) Assumes that the RARF for the slurry is controlled by the behavior of the solvent (water).

(18) The RARF is for the venting of a slurry via an opening at or near the bottom of the sidewall of the vessel; the slurry is conservatively assumed to behave as water although, many of the insoluble particles may be above the respirable size range.

(19) Assumes that the reduction in RARF for venting of a slurry pressurized to 50-500 psig (0.34-3.45 MPa $)$ is proportional to the reduction in RARF between an aqueous solution and an aqueous viscous solution.

(20) For $50-100^{\circ} \mathrm{C}\left(122-212^{\circ} \mathrm{F}\right)$ superheating, $A R F=1 \mathrm{E}-0 \mathrm{~V} / R F$ $0.7 . \mathrm{F}_{1 \mathrm{P}}>100^{\circ} \mathrm{C}\left(212^{\circ} \mathrm{F}\right), A R F=0.33\left[M F_{\mathrm{v}}\right]^{0.91}$

(21) The RARF is for a fine dry powder after a free-fall of $3 \mathrm{~m}$ (10 ft) and impact against a hard unyielding surface and is considered very conservative for salts or damp salts that may be found in a residue in some HLW storage tanks.

(22) Assumes that the impact of an object onto the surface of salt or damp salt suspends as much material as a 3-m (10-ft) free-fall and impact onto a hard unyielding surface of a fine dry powder.

(23) Maximum RARF measured during the venting of a fine, dry powder pressurized to $50 \mathrm{psig}\left(0.34 \mathrm{MPa}_{\mathrm{g}}\right)$ (Sutter 1983 ).

(24) Maximum RARF measured during the heating of a reactive powder in flowing air (Mishima et al. 1968).

(25) Assumes a deflagration of a flammable gas mixture that fills from 10 to $100 \%$ of the free volume above a shallow pile of fine dry powder on a hard unyielding surface. The RARF is reduced by smaller quantities of flammable gas mixture, powder with a tendency to clump (e.g., presence of moisture), or very deep beds of powders that tend to expose lesser fractions of the material at risk to the turbulent entraining flow generated.

(26) Maximum RARF measured during the venting of a fine dry powder pressurized to 50-500 psig (0.34-3.45 MPa $)$ (Sutter 1983). 
(27) Based on the RARF calculated for the spill of calcined alkaline HLW falling $13 \mathrm{~m}$ (43 ft) from cracks and tears in the stainless steel bin in reinforced-concrete vaults toppled by the impact of a large commercial aircraft (reported in INEL EIS) modified for the release of the powder in discrete packets, rather than a single slug (5.2E-02 $\times 0.05=$ $2.75 \mathrm{E}-03$ or $\sim 3 \mathrm{E}-03)$.

(28) Maximum RARF measured during the heating of a fine dry powder on an inert Pu compound (Mishima et al. 1968).

(29) Assume that the blast effects during a detonation are equal to the deflagration considered. The shock effect suspends a mass of powder in the respirable size fraction that is equal to the mass of the TNT Eq estimated for the explosion.

(30) Assume that the spilled canister of solidified vitrified HLW impacts the surface with sufficient force to breech the canister. The RARF is calculated on the basis of the impact energy density imposed on the vitrified waste by the following: $R A R F=A / J(d)(g)(h)$, where $A=$ empirical correlation coefficient $(2 \mathrm{E}-11 \mathrm{~cm} / / D, d=\operatorname{density}$ of the material, $g=$ gravitational acceleration $\left(980 \mathrm{~cm} / \mathrm{s}^{2}\left[32 \mathrm{ft} / \mathrm{s}^{2}\right]\right), h=$ distance of fall $(\mathrm{cm})$, and $J=j o u l e\left(\mathrm{~kg} / \mathrm{m}^{2} \mathrm{~s}^{-1}\right)$. If all of the impact energy is absorbed in a limited volume (e.g., only a corner of the canister is initially impacted), the total energy (in joules) from the falt of the canister and vitrified HLW is assumed to be absorbed in a volume equal to a hemisphere 1.5 times the diameter of the impact area. The canister is assumed to be breached by the impact.

(31) No airborne release is postulated. Assume that internal pressures of $0.34 \mathrm{MPa}_{\mathrm{f}}$ (50 psig) and less are inadequate to breach the canister

(32) No airborne release is postulated. Assume that fires of any size cannot breach the stainless steel canister.

(33) No airborne release is postulated. Assume that external deflagration will not breach the canister.

(34) Maximum RARF measured during the venting of a fine dry powder pressurized to $0.34 \mathrm{MPa}_{\mathrm{g}}$ ( $50 \mathrm{psig}$ ). The materials at risk are the loose particles in the respirable size range exposed on the surface of the vitrified HLW in the canister. The Westinghouse Hanford Company (1993) has reported that $73.1 \mathrm{~g}$ (2.58 oz) of such particles was found in the upper compartment of a canister and represents $3.5 \mathrm{E}-04$ of the $465 \mathrm{~kg}(1,025 \mathrm{lb})$ of vitrified HLW.

(35) The assumption is that the behavior of the molten HLW-glass former mixture is similar to lava (molten rock). On the basis of the "best estimates" available, the viscosity of the molten mixture at the proposed operating temperature $\left(1,150^{\circ} \mathrm{C}\left[2,102^{\circ} \mathrm{F}\right]\right)$ ranges from 20 to $74 \mathrm{P}$. On the basis of on an extrapolation of the empirical correlation for free-fall spills of liquids published by Ayer et al. $\left.(1988), F=\left(d_{\mathrm{a}}^{2}\right)(H)\right](\mathrm{g}) / \mathrm{mu} u_{\mathrm{l}}$, where $F=A R F, d_{\mathrm{a}}=$ density of air $\left(0.746 \mathrm{~kg} / \mathrm{m}^{3}\right)\left(200^{\circ} \mathrm{C}\left[392^{\circ} \mathrm{F}\right]\right.$ for event), $H=$ height of fall $(\mathrm{m})$, $g=$ gravitational acceleration $\left(9.8 \mathrm{~m} / \mathrm{s}^{2}\left[32 \mathrm{ft} / \mathrm{s}^{2}\right]\right)$, and $m u_{1}=$ liquid viscosity (assume 20 P for conservatism). The RARF for a $3-\mathrm{m}(10-\mathrm{ft})$ free-fall is $6.5 \mathrm{E}-09$ to $\sim 7 \mathrm{E}-05$. The $g=$ gravitational acceleration $\left(9.8 \mathrm{~m} / \mathrm{s}^{2}\left(32 \mathrm{ft} / \mathrm{s}^{2}\right)\right.$, and $m u_{1}=$ liquid viscosity (assume $20 \mathrm{P}$ for conservatism). The RARF for a $3-\mathrm{m}(10-\mathrm{ft})$ free-fall is $6.5 \mathrm{E}-09$ to $\sim 7 \mathrm{E}-05$.
release locations considered were the bottom of the pour spout for the melter or the edge of the melter lip when the molten mix begins to spill if the melter is tipped.

(36) Assumes that the impact of an object on the molten mix is equivalent to a 3-m (10-f) free-fall and impact with a hard unyiel ding surface

(37) No significant airborne release is postulated for this situation. Venting of the free space above the molten mix in the melter with a functional air-treatment system does not appear to have the potential to release any significant fraction of the off-gas.

(38) Fires of any size do not appear to generate any additional mechanisms for the airborne release of materials: the molten mixture is normally at a temperature, (1,150 ${ }^{\circ} \mathrm{C}$ $\left.\left[2,102^{\circ} \mathrm{F}\right]\right)$ that is greater than would be anticipated for most accidental fires. The fire may initiate events that would result in airborne release, such as loss of the meltereffluent treatment system or release from collection equipment (e.g., liquid absorbers, HEPA filters) in the effluent-treatment system.

(39) No significant airborne release of the molten mixture is postulated. Deflagrations above the molten surface do not appear to generate conditions that would lead to the subdivision and entrainment of the molten material. Deflagrations may result in the loss of containment and the effluent-treatment system. Loss of containment would result in the release of all radionuclides (volatile and nonvolatile particulates) airborne in the containment at the time of the deflagration

(40) The RARF for a detonation in or on the molten mix is a mass of droplets of molten material in the respirable size range equal to the mass of the TNT Eq estimated for the explosion. The detonation may also initiate other events, such as loss of containment and the off-gas treatment system.

(41) Apply the RARF in footnote 30 for the impact of an aggregate material on a haird unyielding surface after free-fall or the impact of an object on the surface of aggregate material.

(42) Venting of the pressurized atmosphere confined above an aggregate material may entrain any loose fragments or particles on the exposed surfaces. The RARFs for venting of atmosphere pressurized to varinus levels are as follows: for the venting of atmosphere pressurized to $50 \mathrm{psig}\left(0.34 \mathrm{MPa}_{j}\right)$ and less, $2 \mathrm{E}-02$; for venting of atmosphere pressurized to $3.45 \mathrm{MPa}_{\mathrm{g}}(500 \mathrm{psig}), 4 \mathrm{E}-0 \mathrm{z}$

(43) With time, heat and dry air will result in the deterioration of some aggregate materials, such as concrete. Even a relatively thin ( $<2.54-\mathrm{cm}[<1-\mathrm{in}$.]-thick) panel will prevent the propagation of a fire between adjacent spaces for greater than one hour. A RARF of $6 \mathrm{E}-05$ of the loose particles on the exposed surfaces of aggregates during a fire is recommended. If the surface is postulated to deteriorate as a consequence of the fire, the amount of loose particles increases.

(44) Blast effects do not directly result in the fragmentation of large pieces of aggregate. The pressure, flame, and accelerated gas velocities resulting from a deflagration may initiate events leading to the fragmentation of aggregate materials (e.g., failure of structural members such as wall panels, fire, the fragmentation of small pieces of aggregate entrained by the gas flow on impact with a hard unyielding surface). The RARF for a deflagration of a volume of flammable gas mixture that fills from 10 to $100 \%$ of the free volume above the exposed aggregate surface is $1.0 \mathrm{E}$ of the loose respirable particles exposed on the surface. The RARF for a deflagration of a flammable gas mixture that fill $10 \%$ or less of the free volume is estimated to be $1 \mathrm{E}-01$ of the loose respirable particles exposed on the surface.

(45) The RARF for a detonation on or in aggregate materials is a mass equal to the mass of TNT Eq estimated for the explosion. 
TABLE D.6 Threshold Values of Differential Pressure Required to Structurally Damage Standard HEPA Filter

\begin{tabular}{lc}
\hline \multicolumn{1}{c}{ Parameter } & $\begin{array}{c}\Delta \mathrm{P} \text { Threshold } \\
\text { (in. } \mathrm{wg}^{\mathrm{b}} \text { ) }\end{array}$ \\
\hline Baseline (new filter, normal conditions) & 37 \\
& \\
Age (greater than $14 \mathrm{yr}$ ) & 13 \\
Radiation (5E-07 Rad) & 18 \\
Chemical $\left(\mathrm{HNO}_{3}, \mathrm{HF}\right)$ & \\
& $\mathrm{NA}^{\mathrm{c}}$ \\
Temperature & \\
Less than $200^{\circ} \mathrm{C}$ & 37 \\
$200-300^{\circ} \mathrm{C}, 1 \mathrm{~h}$ & 26 \\
$300-400^{\circ} \mathrm{C}, 1 \mathrm{~h}$ & 15 \\
$400-500^{\circ} \mathrm{C}, 1 \mathrm{~h}$ & 8 \\
Moisture (greater than 95\% relative humidity) & 10 \\
\hline
\end{tabular}

a These values were determined from an analysis of experimental studies reviewed in Bergman (1993).

b $w g=$ water gauge.

c $\mathrm{NA}=$ not applicable. 
TABLE D.7 Effects of Environmental Filter Parameters on Aerosol Penetration through HEPA Filters

\begin{tabular}{lc}
\hline \multicolumn{1}{c}{ Parameter } & $\begin{array}{c}\text { Filter } \\
\text { Penetration }\end{array}$ \\
\hline Baseline & 0.1 \\
HF corrosion & \\
$(1,500$ ppm-h) & 0.1 \\
Temperature & \\
$<200^{\circ} \mathrm{C}$ & \\
$200-300^{\circ} \mathrm{C}, 10$ min & 0.0 \\
$300-350^{\circ} \mathrm{C}, 10$ min & 0.1 \\
$350-500^{\circ} \mathrm{C}, 10$ min & 0.4 \\
Moisture (water mist & 1.0 \\
loaded to 8 in. wg) & \\
Particle deposits & 0.1 \\
Solids \\
Liquid DOP ${ }^{\mathrm{a}}$ loaded to \\
4 in. wg \\
Air flow \\
(10 $\times$ rated flow) \\
Air pulse \\
(1-psi 47 -ms pulse)
\end{tabular}

a $\mathrm{DOP}=$ dioctyl phthalate.

b $100 \times$ increase in penetration.

Source: Bergman (1993). 
TABLE D.8 Summary of Reduction and Removal Factors Abstracted from Elder et al. (1986)

\begin{tabular}{|c|c|c|c|c|}
\hline Release Mechanism & Safety Analysis Parameter & $\begin{array}{c}\text { Range of } \\
\text { Observation }\end{array}$ & $\begin{array}{l}\text { Currer: } \\
\text { Practice }\end{array}$ & $\begin{array}{c}\text { Recommended } \\
\text { Value }\end{array}$ \\
\hline $\begin{array}{l}\text { Particulate filters } \\
\text { (\% efficiency) }\end{array}$ & $\begin{array}{r}\text { (a) HEPA : } \text { Ist stage } \\
\text { 2nd stage } \\
\text { 3rd stage } \\
\text { 4th stage } \\
\text { (b) Sand filter bed } \\
\text { (c) Fiber glass (deep bed) }\end{array}$ & $\begin{array}{c}96.0-99.999 \\
99.976-99.992 \\
99.49-99.99+ \\
- \\
99.60-99.999 \\
70-99.995\end{array}$ & $\begin{array}{c}99.0-99.99 \\
99.0-99.9 \\
94.0-99.8 \\
83.0 \\
99.0 \\
90.0\end{array}$ & $\begin{array}{l}99.9^{\mathrm{a}} \\
99.0^{\mathrm{a}} \\
99.0^{\mathrm{a}} \\
83.0^{\mathrm{a}} \\
99.0 \\
90.0\end{array}$ \\
\hline $\begin{array}{l}\text { Noble gas traps } \\
\text { (\% efficiency) }\end{array}$ & $\begin{array}{l}\text { (a) Refrigerant } \\
\text { (b) Cryogenic }\left(\mathrm{CO}_{2}\right)\end{array}$ & $\begin{array}{l}75.0-99.99+ \\
90.0-99.993\end{array}$ & $\dot{-}$ & $\begin{array}{l}\mathrm{NR}^{\mathrm{c}} \\
\mathrm{NR}\end{array}$ \\
\hline $\begin{array}{l}\text { Halogen filters } \\
\text { (\% efficiency for bed } \\
\text { depth } \geq 5 \mathrm{~cm} \text { ) }\end{array}$ & $\begin{array}{l}\text { (a) Activated charcoal } \\
\mathrm{I}_{2} \text { at } \mathrm{RH}<70 \% \\
\mathrm{I}_{2} \text { at } \mathrm{RH}>70 \% \\
\mathrm{CH}_{3} \mathrm{I} \text { at } \mathrm{RH}<70 \% \\
\mathrm{CH}_{3} \mathrm{I} \text { at } \mathrm{RH}>70 \% \\
\text { (b) } \mathrm{Inorganic} \text { adsorber } \\
\mathrm{I}_{2}: \text { low loading } \\
\mathrm{I}_{2}: \text { high loading } \\
\mathrm{CH}_{3} \mathrm{I}: \text { low loading } \\
\mathrm{CH}_{3} \mathrm{I}: \text { high loading } \\
\text { (c) } \mathrm{Silver} \mathrm{zeolite} \\
\mathrm{I}_{2} \\
\mathrm{CH}_{3} \mathrm{I}\end{array}$ & $\begin{array}{c}81.9-99.999 \\
>90.0-99.9997 \\
50.25-99.999+ \\
8.77-99.99 \\
\\
99.0-99.9997 \\
57.0-76.0 \\
80.0-99.9997 \\
45.9-99.0 \\
\\
99.0-99.99+ \\
90.0-99.999\end{array}$ & $\begin{array}{c}95.0-99.99 \\
90.0 \\
85.0-99.0 \\
30.0-98.0\end{array}$ & $\begin{array}{l}99.0 \\
50.0 \\
99.0 \\
50.0 \\
\\
99.0 \\
99.0\end{array}$ \\
\hline
\end{tabular}

a Alternate values may be appropriate, depending on accident scenario and more detailed information on filtration systems.

b A hyphen indicates data not available.

- $\mathrm{NR}=$ no recommendation.

d $\mathrm{RH}=$ relative humidity.

- Low loading $=<50 \mathrm{mg}$ of $\mathrm{I}_{2}$ or $\mathrm{CH}_{3} \mathrm{I}$ of adsorber.

Source: Adapted from Elder et al. (1986). 
TABLE D.9 Mapping of WM PEIS Treatability Categories for LLW with Accident Analysis Physical Forms ${ }^{\mathrm{a}}$

\begin{tabular}{|c|c|c|c|c|}
\hline $\begin{array}{l}\text { WM PEIS Treatability } \\
\text { Category }\end{array}$ & Technology & Form ${ }^{b}$ & $\begin{array}{l}\text { Accident Physical } \\
\text { Form }\end{array}$ & Comments/Assumptions \\
\hline \multirow[t]{2}{*}{ Aqueous liquids } & $\begin{array}{l}\text { General aqueous } \\
\text { treatment }^{\mathrm{e}}\end{array}$ & Product & Aqueous solution & Output waste form is a dilute aqueous LLW solution. \\
\hline & & Solid residual & Aqueous slurry & Solid residual is an aqueous slurry to be sent for solidification. \\
\hline Aqueous liquids & Current storage & Input & Aqueous solution & Input waste form is a dilute aqueous LLW solution. \\
\hline \multirow[t]{2}{*}{ Aqueous liquids } & Evaporation & Product & $\begin{array}{l}\text { Superheated } \\
\text { aqueous solution }\end{array}$ & $\begin{array}{l}\text { Assumes dominant accident scenarios involve release of evaporator } \\
\text { contents (at high temperature and pressure) and radionuclide } \\
\text { composition of product stream similar to evaporator contents. }\end{array}$ \\
\hline & & Solid residual & Aqueous slurry & $\begin{array}{l}\text { Evaporator residual is aqueous slurry with a high solids } \\
\text { concentration to be sent for solidification. }\end{array}$ \\
\hline Aqueous liquids & Solidification & Product & $\begin{array}{l}\text { Noncombustible } \\
\text { aggregated solids }\end{array}$ & $\begin{array}{l}\text { Noncombustible aggregated solids surrogate for grout monolithic } \\
\text { product. }\end{array}$ \\
\hline Combustible solids & Current storage & Input & DAW & Based on waste form description given in Goyette (1995). \\
\hline \multirow[t]{2}{*}{ Combustible solids } & Incineration & Product & $\begin{array}{l}\text { Noncombustible } \\
\text { powder }\end{array}$ & \\
\hline & & Liquid residual & Aqueous solution & $\begin{array}{l}\text { Slurry blowdown from off-gas treatment is an aqueous solution } \\
\text { (Goyette 1995). }\end{array}$ \\
\hline Combustible solids & Packaging & Product & DAW & Assumes packaging does not affect physical form. \\
\hline Combustible solids & Solidification & Product & $\begin{array}{l}\text { Noncombustible } \\
\text { aggregated solids }\end{array}$ & $\begin{array}{l}\text { Noncombustible aggregated solids surrogate for grout monolithic } \\
\text { product. }\end{array}$ \\
\hline \multirow[t]{2}{*}{ Combustible solids } & $\alpha$-incineration & Product & $\begin{array}{l}\text { Noncombustible } \\
\text { powder }\end{array}$ & \\
\hline & & Liquid residual & Aqueous solution & \\
\hline Combustible solids & $\alpha$-solidification & Product & $\begin{array}{l}\text { Noncombustible } \\
\text { aggregated solid }\end{array}$ & $\begin{array}{l}\text { Noncombustible aggregated solids surrogate for grout monolithic } \\
\text { product. }\end{array}$ \\
\hline Activated metals & Current storage & Input & Inert metal & Based on waste form description given in Goyette (1995). \\
\hline Activated metals & Packaging & Product & Inert metal & Assumes packaging does not affect physical form. \\
\hline
\end{tabular}


TABLE D.9 (Cont.)

\begin{tabular}{|c|c|c|c|c|}
\hline $\begin{array}{l}\text { WM PEIS Treatability } \\
\text { Category }\end{array}$ & Technology & Form ${ }^{b}$ & $\begin{array}{l}\text { Accident Physical } \\
\text { Form }\end{array}$ & Comments/Assumptions \\
\hline Activated metals & Size reduction & Product & Inert metal & $\begin{array}{l}\text { Assumes production of noncombustible powder during size reduction } \\
\text { is negligible, based on release fraction information for normal } \\
\text { operations (Goyette 1995). }\end{array}$ \\
\hline Sfc-contaminated metals & Current storage & Input & $\begin{array}{l}\text { Noncombustible } \\
\text { powder }\end{array}$ & $\begin{array}{l}\text { Noncombustible powder assumed to contaminate outer surfaces of } \\
\text { waste. }\end{array}$ \\
\hline \multirow[t]{2}{*}{ Sfc-contaminated metals } & Decontamination & Product & Inert metal & $\begin{array}{l}\text { Assumes decontamination removes surface contamination resulting } \\
\text { in a potentially activated metal. }\end{array}$ \\
\hline & & Liquid residual & Aqueous slurry & Based on waste form description given in Goyette (1995). \\
\hline \multirow[t]{2}{*}{ Sfc-contaminated metals } & Metal melting & Product & $\begin{array}{l}\text { Viscous (molten) } \\
\text { liquid }\end{array}$ & $\begin{array}{l}\text { Assumes dominant accident scenario involves process upset during } \\
\text { melting stage and radionuclide composition of product stream } \\
\text { similar to molten material. }\end{array}$ \\
\hline & & Liquid residual & Aqueous slurry & Based on waste form description given in Goyette (1995). \\
\hline Sfc-contaminated metals & Packaging & Product & Inert metal & Assumes packaging does not affect physical form. \\
\hline Sfc-contaminated metals & Size reduction & Product & Inert metal & Based on waste form description given in Goyette (1995). \\
\hline Sfc-contaminated metals & $\alpha$-size reduction & Product & Inert metal & Based on waste form description given in Goyette (1995). \\
\hline $\begin{array}{l}\text { Noncombustible- } \\
\text { noncompactible solids }\end{array}$ & Current storage & Input & Inert metal & Based on waste form description given in Goyette (1995). \\
\hline $\begin{array}{l}\text { Noncombustible- } \\
\text { noncompactible solids }\end{array}$ & Packaging & Product & Inert metal & Assumes packaging does not affect physical form. \\
\hline $\begin{array}{l}\text { Noncombustible- } \\
\text { noncompactible solids }\end{array}$ & Solidification & Product & $\begin{array}{l}\text { Noncombustible } \\
\text { aggregated solid }\end{array}$ & $\begin{array}{l}\text { Noncombustible aggregated solids surrogate for grout monolithic } \\
\text { product. }\end{array}$ \\
\hline $\begin{array}{l}\text { Noncombustible- } \\
\text { noncompactible solids }\end{array}$ & $\alpha$-solidification & Product & $\begin{array}{l}\text { Noncombustible } \\
\text { aggregated solid }\end{array}$ & $\begin{array}{l}\text { Noncombustible aggregated solids surrogate for grout monolithic } \\
\text { product. }\end{array}$ \\
\hline $\begin{array}{l}\text { Noncombustible- } \\
\text { noncompactible solids }\end{array}$ & Supercompaction & $\begin{array}{l}\text { Product } \\
\text { liquid residual }\end{array}$ & $\begin{array}{l}\text { Inert metal } \\
\text { aqueous solution }\end{array}$ & $\begin{array}{l}\text { Assumes supercompaction does not affect initial physical form. } \\
\text { Fugitive liquids from supercompaction stated to be an aqueous } \\
\text { solution (Feizollahi and Shropshire 1992). }\end{array}$ \\
\hline
\end{tabular}




\begin{tabular}{|c|c|c|c|c|}
\hline $\begin{array}{l}\text { WM PEIS Treatability } \\
\text { Category }\end{array}$ & Technology & Form $^{b}$ & $\begin{array}{l}\text { Accident Physical } \\
\text { Form }\end{array}$ & Comments/Assumptions \\
\hline $\begin{array}{l}\text { Noncombustible- } \\
\text { noncompactible solids }\end{array}$ & $\alpha$-supercompaction & $\begin{array}{l}\text { Product } \\
\text { Liquid residual }\end{array}$ & $\begin{array}{l}\text { Inert metal } \\
\text { Aqueous solution }\end{array}$ & $\begin{array}{l}\text { Assumes } \alpha \text {-supercompaction does not affect initial physical form. } \\
\text { Fugitive liquids from } \alpha \text {-supercompaction stated to be an aqueous } \\
\text { solution (Feizollahi and Shropshire 1992). }\end{array}$ \\
\hline Organic liquids & Current storage & Input & $\begin{array}{l}\text { Organic combustible } \\
\text { liquid }\end{array}$ & Based on waste form description given in Goyette (1995). \\
\hline Organic liquids & Incineration & $\begin{array}{l}\text { Product } \\
\text { Liquid residual }\end{array}$ & $\begin{array}{l}\text { Noncombustible } \\
\text { powder } \\
\text { Aqueous solution }\end{array}$ & $\begin{array}{l}\text { Assumes organic liquids contain both suspended and dissolved } \\
\text { solids, so that incinerator ash is a noncombustible powder. } \\
\text { Assumes slurry blowdown from off-gas treatment is an aqueous } \\
\text { solution. }\end{array}$ \\
\hline Organic liquids & $\alpha$-incineration & $\begin{array}{l}\text { Product } \\
\text { Liquid residual }\end{array}$ & $\begin{array}{l}\text { Noncombustible } \\
\text { powder } \\
\text { Aqueous solution }\end{array}$ & $\begin{array}{l}\text { Assumes organic liquids contain both suspended and dissolved } \\
\text { solids, so that incinerator ash is a noncombustible powder. } \\
\text { Slurry blowdown from off-gas treatment is an aqueous solution } \\
\text { (Goyette 1995). }\end{array}$ \\
\hline Organic liquids & Solidification & Product & $\begin{array}{l}\text { Noncombustible } \\
\text { aggregated solid }\end{array}$ & $\begin{array}{l}\text { Assumes product from solidification process is a nonflammable } \\
\text { monolithic solid. }\end{array}$ \\
\hline Organie liquids & $\alpha$-solidification & Product & $\begin{array}{l}\text { Noncombustible } \\
\text { aggregated solid }\end{array}$ & $\begin{array}{l}\text { Assumes product from } \alpha \text {-solidification process is a nonflammable } \\
\text { monolithic solid. }\end{array}$ \\
\hline Organic liquids & Packaging & Product & $\begin{array}{l}\text { Organic combustible } \\
\text { liquid }\end{array}$ & $\begin{array}{l}\text { Assumes packaging does not affect physical form although packaging } \\
\text { of liquid generally involves addition of absorbent to remove excess } \\
\text { free liquids prior to shipment. }\end{array}$ \\
\hline Other/special case & Current storage & Input & Inert metal & $\begin{array}{l}\text { Accident analysis assumption due to lack of information about this } \\
\text { waste form. }\end{array}$ \\
\hline Other/special case & Packaging & Product & Inert metal & Assumes packaging does not affect physical form. \\
\hline Remote-handled & Current storage & Input & Inert metal & Typically activated metal waste. \\
\hline Remote-handled & Packaging & Product & Inert metal & Assumes packaging does not affect physical form. \\
\hline Sludge/resin & Current storage & Input & Aqueous slurry & Sludge/resin form stated to be "wet solid" (Goyette 1995). \\
\hline
\end{tabular}




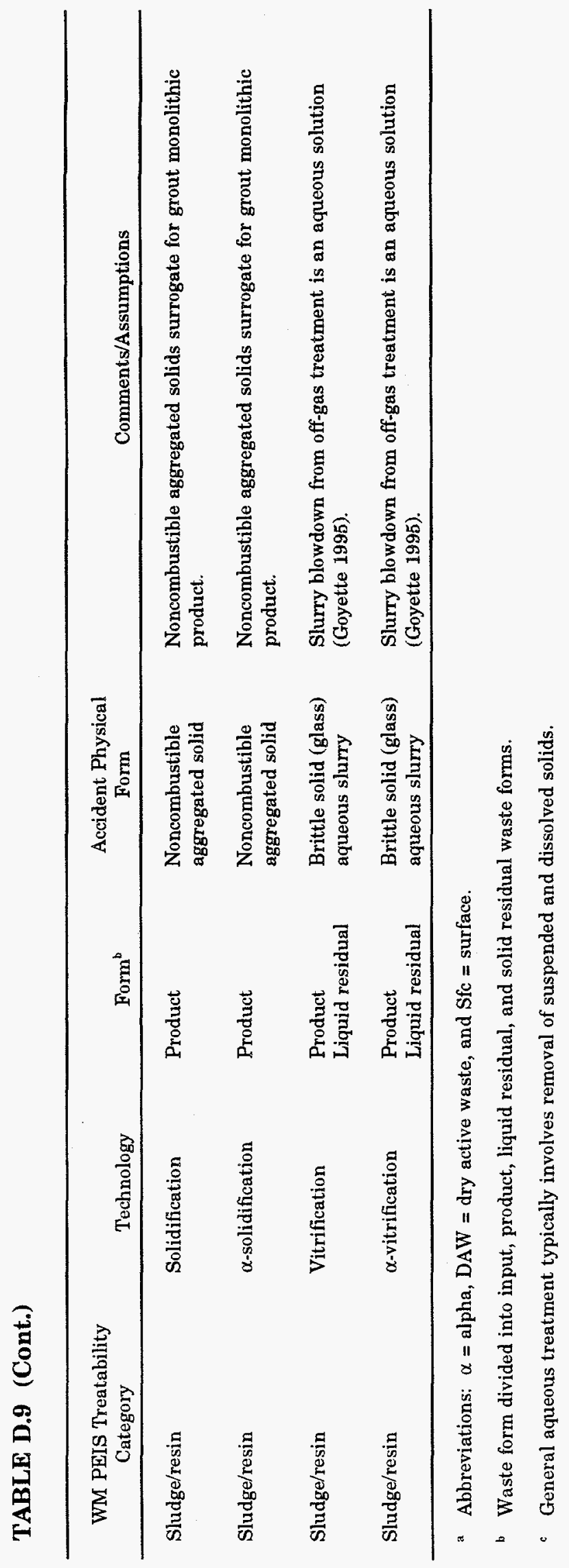




\begin{tabular}{lll}
$\begin{array}{c}\text { WM PEIS Treatability } \\
\text { Category }\end{array}$ & Accident Physical Form & \multicolumn{1}{c}{ Comments/Assumptions } \\
\hline $\begin{array}{l}\text { Organic liquid } \\
\text { Aqueous liquid }\end{array}$ & $\begin{array}{l}\text { Organic combustible } \\
\text { solution }\end{array}$ & $\begin{array}{l}\text { Input waste form consists of flammable components (i.e, petroleum distillates, } \\
\text { solvents) with low amounts of suspended solids. }\end{array}$ \\
$\begin{array}{l}\text { Organic sludges/ } \\
\text { particulates }\end{array}$ & $\begin{array}{l}\text { Organic combustible } \\
\text { slurry }\end{array}$ & $\begin{array}{l}\text { Input waste form is a dilute aqueous TRUW solution. } \\
\text { the particulate surfaces "wetted" by the solution. If, however, the particulates are } \\
\text { not in intimate contact with the solution so that they can be considered easily } \\
\text { dispersible, then the accident category of "Combustible Powder" may be more } \\
\text { appropriate. }\end{array}$ \\
$\begin{array}{l}\text { Inorganic sludges/ } \\
\text { particulates }\end{array}$ & Aqueous slurry & $\begin{array}{l}\text { Based on logic of previous treatability category. If, however the particulates are not } \\
\text { in intimate contact with the solution so that they can be considered easily } \\
\text { dispersible, then the accident category of "Noncombustible Powder" may be more } \\
\text { appropriate. }\end{array}$
\end{tabular}

Cemented solids Noncombustible aggregated solid

Organic debris

Dry active waste

Inorganic debris

Inert metal

Heterogeneous debris

Inert metal

Soils with $<50 \%$

debris

Soils without debris
Noncombustible powder

Noncombustible powder
Noncombustible aggregated solids surrogate for cemented solids; would expect minimal risk from any potential current storage accidents, unless the cohesiveness of the cement has been degraded.

Based on waste form description (Oak Ridge National Laboratory 1994).

Waste includes construction materials, equipment, and structures. Assumes that decontamination of waste has been performed so that the remaining radioactivity is due to induced activity.

Logic used for "Inorganic Debris" also applied to this treatability category.

Based on Mishima's original accident categories which were taken from the WRAP II safety documentation (Westinghouse Hanford Company 1991).

As above. 
TABLE D.10 (Cont.)

\begin{tabular}{ccc}
$\begin{array}{c}\text { WM PEIS Treatability } \\
\text { Category }\end{array}$ & Accident Physical Form & Comments/Assumptions \\
\hline
\end{tabular}

Lab packs with

metals

Lab packs without

metals

Dry active waste

Reactive metals

Reactive metal

Explosives

Combustible powder

Compressed gases

Mercury, liquid see comments/ assumptions
Dry active waste

Mishima's RARFs for dry active waste were developed from available data for combustible trash and "lab packs;" assume that the presence of RCRA toxic metals will not significantly affect the release characteristics of this treatability category (DOE 1994a)

Mishima's RARFs (DOE 1994a) for dry active waste were developed from available data for combustible trash and "lab packs."

\section{By definition.}

When the accident physical forms were initially developed, the WM PEIS treatability categories for TRUW did not include this treatability category. Further information on the nature of contamination is required; it may, however, be expected that the explosive material has a fine layer of surface contamination. In this case, the "Combustible Powder" accident physical form may be applicable. For assessment of shock-induced explosions, the TNT equivalence of various explosives given in Table 3.4 of NUREG-1320 (NRC 1988) may be used. However, it should be noted that the release of energy may be great enough to cause failure of containment boundaries and lead to opening of alternative flow paths during an accident, affecting the LPF.

Waste-form dependent:

Waste-form dependent: see comments/ assumptions
The release category is dependent on the compressed gas(es); if the gas is a noncondensible or a noble gas, then the "Noble Gas" category should be applied. A similar situation applies for halogens and condensible vapors.

When the accident physical forms were initially developed, the WM PEIS treatability categories for TRUW did not include this treatability category. It is assumed that the solution and not the mercury itself is radioactively contaminated. One significant mercury-containing solution is the LLMW stream generated at the Savannah River Site (SRS) during reprocessing and other waste processing steps. The SRS stream is an organic liquid containing small amounts of mercury; in this case, the "Organic Combustible Solution" accident physical form may be applicable. Aqueous solutions containing mercury are also present; in this case, the appropriate accident physical form would be "Aqueous Liquids, Solutions." 
TABLE D.10 (Cont.)

\begin{tabular}{|c|c|c|}
\hline $\begin{array}{l}\text { WM PEIS Treatability } \\
\text { Category }\end{array}$ & Accident Physical Form & Comments/Assumptions \\
\hline Lead, elemental & $\begin{array}{l}\text { Waste-form dependent: } \\
\text { see comments/ } \\
\text { assumptions }\end{array}$ & $\begin{array}{l}\text { When the accident physical forms were initially developed, the WM PEIS } \\
\text { treatability categories for TRUW did not include this treatability category. This } \\
\text { treatability category may in general contain both surface contamination and } \\
\text { induced lead. In the case of surface contamination (of radionuclides other than } \\
\text { lead), then the "Noncombustible Powder" accident physical form may be applied. If } \\
\text { however, this stream contains significant amounts of induced activity, then the } \\
\text { "Inert Metal" physical form may be more appropriate for accident stresses that do } \\
\text { not involve high temperatures (e.g., mechanical releases). }\end{array}$ \\
\hline Beryllium, dust & $\begin{array}{l}\text { Waste-form dependent: } \\
\text { see comments/ } \\
\text { assumptions }\end{array}$ & See above. \\
\hline $\begin{array}{l}\text { Batteries, lead-acid, } \\
\text { cadmium }\end{array}$ & Noncombustible powder & $\begin{array}{l}\text { Assumes that neither the lead nor cadmium are radioactive, and that the majority } \\
\text { of the radioactivity is associated with surface contamination. }\end{array}$ \\
\hline Other/multiple & $\begin{array}{l}\text { Waste-form dependent: } \\
\text { see comments/ } \\
\text { assumptions }\end{array}$ & $\begin{array}{l}\text { Limited information is available on the physical properties of this treatability } \\
\text { category. The appropriate accident physical form would be determined from the } \\
\text { treatment processes used to immobilize this waste stream; if supercompaction is } \\
\text { used, then "Inert Metal" may be appropriate. If liquid/solid separation is required, } \\
\text { the waste may be considered to be an "Organic Solution" if combustible liquids are } \\
\text { present, or an "Aqueous Slurry" if the liquid is not combustible. }\end{array}$ \\
\hline
\end{tabular}




\begin{tabular}{|c|c|c|c|c|}
\hline Site $^{(a)}$ & TSD Function & $\begin{array}{l}\text { Material at Risk Based on the } \\
\text { Contents of: }\end{array}$ & $\begin{array}{l}\text { Accident Physical } \\
\text { Form }\end{array}$ & Comments/Assumptions \\
\hline Hanford & $\begin{array}{l}\text { Current tank } \\
\text { storage }\end{array}$ & One double-shell tank (DST) & Aqueous slurry & $\begin{array}{l}\text { DST waste consists of mixtures of HLW, TRUW, and } \\
\text { LLW existing as crystallized salts or oxides and is } \\
\text { considered to be aqueous slurry (ORNL 1992). }\end{array}$ \\
\hline Hanford & Retrieval & Retrieval line & Aqueous solution & $\begin{array}{l}\text { Hydraulic retrieval assumed, which involves adding } \\
\text { water to mobilize waste prior to transport. }\end{array}$ \\
\hline Hanford & Pretreatment & $\begin{array}{l}\text { Conceptual Pretreatment } \\
\text { Facility }\end{array}$ & Aqueous solution & $\begin{array}{l}\text { Review of conceptual Hanford pretreatment facility } \\
\text { design (Boomer 1992) indicated that the majority of } \\
\text { the HLW within the facility is an aqueous solution. }\end{array}$ \\
\hline Hanford & Pretreatment & $\begin{array}{l}\text { Fully-loaded cesium ion- } \\
\text { exchange column }\end{array}$ & $\begin{array}{l}\text { Combustible solids - } \\
\text { polyethylene }\end{array}$ & $\begin{array}{l}\text { Radioactive cesium assumed to be removed by a } \\
\text { Duolite-like ion-exchange resin made of polyethylene. }\end{array}$ \\
\hline Hanford & Pretreatment & $\begin{array}{l}\text { 1,000-gal double-containment } \\
\text { receiver tank (DCRT) }\end{array}$ & Aqueous slurry & $\begin{array}{l}\text { Slurry is formed from retrieved waste due to } \\
\text { recirculation (concentration factor of approximately } \\
\text { three times). }\end{array}$ \\
\hline Hanford & Treatment & Vitrification melter & $\begin{array}{l}\text { Viscous (molten) } \\
\text { liquid }\end{array}$ & $\begin{array}{l}\text { Molten glass spill due to failure of melter drain } \\
\text { system, material at risk consists of borosilicate glass } \\
\text { similar in behavior to molten lava. }\end{array}$ \\
\hline Hanford & Treatment & Vitrification melter & $\begin{array}{l}\text { Viscous (molten) } \\
\text { liquid }\end{array}$ & $\begin{array}{l}\text { Steam-glass explosion due to failure of cooling } \\
\text { system, material at risk consists of borosilicate glass } \\
\text { similar in behavior to molten lava. }\end{array}$ \\
\hline Hanford & Treatment & $\begin{array}{l}\text { Hanford Waste Vitrification } \\
\text { Plant (HWVP) }\end{array}$ & Aqueous slurry & $\begin{array}{l}\text { External event assumed to result in rupture of all } \\
\text { waste holding tanks and spillage of molten glass; } \\
\text { molten glass spill neglected based on Herborn and } \\
\text { Smith (1990) due to low inventory in comparison } \\
\text { with entire facility and low release fraction. }\end{array}$ \\
\hline
\end{tabular}




\begin{tabular}{|c|c|c|c|c|}
\hline Site $^{a}$ & TSD Function & $\begin{array}{l}\text { Material at Risk Based on the } \\
\text { Contents of: }\end{array}$ & $\begin{array}{l}\text { Accident Physical } \\
\text { Form }\end{array}$ & Comments/Assumptions \\
\hline Hanford & $\begin{array}{l}\text { Glass canister } \\
\text { storage }\end{array}$ & One HLW glass canister & Brittle solids (glass) & $\begin{array}{l}\text { Brittle (glass) solids surrogate for borosilicate-type } \\
\text { glass produced during vitrification. }\end{array}$ \\
\hline SRS & $\begin{array}{l}\text { Current tank } \\
\text { storage }\end{array}$ & One Type-III tank & Aqueous solution & $\begin{array}{l}\text { Majority of the SRS HLW inventory }(\approx 45 \%) \\
\text { associated with the alkaline liquid, which has a high } \\
\text { salt content solution with many crystallized salt } \\
\text { solids. }\end{array}$ \\
\hline SRS & Retrieval & Retrieval line & Aqueous solution & $\begin{array}{l}\text { Hydraulic retrieval assumed, which involves adding } \\
\text { water to mobilize waste prior to transport. }\end{array}$ \\
\hline SRS & Pretreatment & One Type-III tank & Aqueous solution & $\begin{array}{l}\text { Based on material characteristics for in-tank } \\
\text { precipitation process given in Choi and Fowler } \\
(1990) \text {. }\end{array}$ \\
\hline SRS & Pretreatment & Salt cake tank & Aqueous slurry & $\begin{array}{l}\text { Salt cake tank contains washed sludge waste } \\
\text { assumed to be equivalent in physical form to an } \\
\text { aqueous slurry. }\end{array}$ \\
\hline SRS & Treatment & Slurry mix evaporator (SRE) & $\begin{array}{l}\text { Superheated aqueous } \\
\text { solution }\end{array}$ & $\begin{array}{l}\text { Dominant accident scenario in literature involves } \\
\text { release of evaporator contents at high pressure and } \\
\text { temperature (WSRC 1990; WSRC 1991). }\end{array}$ \\
\hline SRS & Treatment & $\begin{array}{l}\text { Slurry receipt and adjustment } \\
\text { Tank (SRAT) }\end{array}$ & Aqueous slurry & $\begin{array}{l}\text { SRAT contains washed sludge, which is assumed to } \\
\text { be equivalent in physical form to an aqueous slurry. }\end{array}$ \\
\hline SRS & Treatment & Vitrification melter & $\begin{array}{l}\text { Viscous (molten) } \\
\text { liquid }\end{array}$ & $\begin{array}{l}\text { Steam-glass explosion due to failure of cooling } \\
\text { system, material-at-risk consists of borosilicate glass } \\
\text { similar in behavior to molten lava. }\end{array}$ \\
\hline
\end{tabular}


TABLE D.11 (Cont.)

\begin{tabular}{lccc}
\hline & Material at Risk Based on the \\
Site & TSD Function & Contents of: & Form \\
\hline
\end{tabular}

SRS Treatment Defense Waste Processing Aqueous slurry
Facility (DWPF)

External event assumed to result in rupture of all waste holding tanks and spillage of molten glass; molten glass spill neglected based on WSRC (1993) due to low inventory in comparison with entire facility and low release fraction.

\begin{tabular}{|c|c|c|c|c|}
\hline SRS & $\begin{array}{l}\text { Glass canister } \\
\text { storage }\end{array}$ & One HLW glass canister & Brittle solids (glass) & $\begin{array}{l}\text { Brittle (glass) solids surrogate for borosilicate-type } \\
\text { glass produced during vitrification. }\end{array}$ \\
\hline WVDP $^{\mathrm{b}}$ & Pretreatment & Tank 8D-2 & Aqueous slurry & $\begin{array}{l}\text { Tank } 8 D-2 \text { contains washed sludge waste assumed to } \\
\text { be equivalent in physical form to an aqueous slurry. }\end{array}$ \\
\hline WVDP & Treatment & $\begin{array}{l}\text { Concentrator feed makeup } \\
\text { tank (CFMUT) }\end{array}$ & Aqueous slurry & $\begin{array}{l}\text { Based on waste description given in Barnes et al. } \\
\text { (1988). }\end{array}$ \\
\hline WVDP & Treatment & Vitrification melter & $\begin{array}{l}\text { Viscous (molten) } \\
\text { liquid }\end{array}$ & $\begin{array}{l}\text { Steam-glass explosion due to failure of cooling } \\
\text { system, material at risk consists of borosilicate glass } \\
\text { similar in behavior to molten lava. }\end{array}$ \\
\hline WVDP & Treatment & Vitrification Facility & Aqueous slurry & $\begin{array}{l}\text { External event assumed to result in rupture of all } \\
\text { waste holding tanks and spillage of molten glass; } \\
\text { molten glass spill neglected due to low inventory in } \\
\text { comparison with entire facility and low release } \\
\text { fraction. }\end{array}$ \\
\hline WVDP & $\begin{array}{l}\text { Glass canister } \\
\text { storage }\end{array}$ & One HLW glass canister & Brittle solids (glass) & $\begin{array}{l}\text { Brittle (glass) solids surrogate for borosilicate-type } \\
\text { glass produced during vitrification. }\end{array}$ \\
\hline
\end{tabular}

a HLW accident analysis for Idaho National Engineering Laboratory (INEL) not included because of nonexistent safety documentation for the immobilization process and possible conflicts with the accident analysis for the INEL site-wide EIS.

b WVDP $=$ West Valley Demonstration Project. 


\section{D.4 REFERENCES}

Ayer, J.E., et al., 1988, Nuclear Fuel Cycle Accident Analysis Handbook, NUREG-1320, U.S. Nuclear Regulatory Commission, Washington, D.C., May.

Ballinger, M.Y., and W.H. Hodgson, 1986 Aerosols Generated by Spills of Viscous Solutions and Slurries, NUREG/CR-4658, Pacific Northwest Laboratory, Richland, Wash.

Barnes, S.M., et al., 1988, "Three Year's Progress of the West Valley Demonstration Project Vitrification System," in Proceedings of Waste Management '88, R. Post and M. Walks (editors), Laser Options, Inc., Tucson, Ariz., pp. 195-202.

Bergman, W., 1993, Efficiency of HEPA Filtration Systems during and after Design Basis Accidents, Draft, Lawrence Livermore Laboratory, Livermore, Calif.

Boomer, K.D., 1992, Tank Waste Systems Engineering Study, WHC-EP-0405, rev. 0, prepared by Westinghouse Hanford Co., Richland, Wash., for U.S. Department of Energy, Office of Environmental Restoration and Waste Management, Oct.

Choi, A.S., and J.R. Fowler, 1990, Material Balance Tables for the DWPF Basic Data Report. Revision 138: Appendix G, Table 19-1, WSRC-TR-90-93, Westinghouse Savannah River Co., Aiken, S.C., Feb.

DOE. See U.S. Department of Energy.

Elder, J.C., et al., 1986, A Guide to Radiological Accident Considerations for Siting and Design of DOE Nonreactor Nuclear Facilities, LA-10294-MS/UC-41, Los Alamos National Laboratory, Los Alamos, N.M.

Feizollahi, F., and D. Shropshire, 1992, Waste Management Facilities Cost Information Report, EGG-WTD-10443, EG\&G Idaho, Inc., Idaho Falls, Idaho, Oct.

Goyette, M.L., 1995, Low-Level Waste Inventory, Characteristics, Generation, and Facility Assessment for Treatment, Storage, and Disposal Alternatives Considered in the U.S. Department of Energy Waste Management Programmatic Environmental Impact Statement, ANL/EAD/TM-20 (Draft), Argonne National Laboratory, Argonne, Ill.

Herborn, D.I., and D.A. Smith, 1990, Hanford Waste Vitrification Plant Preliminary Safety Analysis Report, WHC-EP-0250, rev. B, draft, Westinghouse Hanford Company, Richland, Wash., July.

Mishima, J., et al., 1968, Plutonium Release Studies III. Release from Heated Plutonium Bearing Powders, BNWL-786, Pacific Northwest Laboratory, Richland, Wash.

NRC. See U.S. Nuclear Regulatory Commission. 
Oak Ridge National Laboratory, 1992, Integrated Data Base for 1992: U.S. Spent Fuel and Radioactive Waste Inventories, Projections, and Characteristics, DOE/RW-0006, rev. 8, prepared for U.S. Department of Energy, Oak Ridge, Tenn., Oct.

Oak Ridge National Laboratory, 1994, Integrated Data Base for 1993: U.S. Spent Fuel and Radioactive Waste Inventories, Projections, and Characteristics, DOE/RW-0006, rev. 9, U.S. Department of Energy, Oak Ridge, Tenn., March.

Restrepo, L.F., 1992, The Annular Core Research Reactor (ACRR) Limiting Event for Worker and Public Consequences, SAND91-0572, Sandia National Laboratories, Albuquerque, N.M.

Roblyer, S.P., and P.C. Owczarski, 1992, "Determining Wind Spray Release from Effluent Disposal Ponds," presented at Hazmacon '92, Long Beach, Calif., March 30-April 2.

Soffer, L., 1993, "Review of Reactor Accident Source Terms and Implications for Nuclear Air Cleaning Requirements," Proceedings of the 22nd DOE/NRC Nuclear Air Cleaning Conference, NUREG-CP-0130, U.S. Nuclear Regulatory Commission, Washington, D.C.

Steindler, M.J., and W.H. Seefeldt, 1980, "A Method for Estimating the Challenge to an Air Cleaning System," in Proceedings of the 16th DOE Air Cleaning Conference, CONF-801038, Harvard Air Cleaning Laboratory, Boston, Mass.

Sutter, S.L., 1983, Aerosols Generated by Release of Pressurized Powders and Solutions in Static Air, NUREG/CR-3093, Pacific Northwest Laboratory, Richland, Wash.

Teleyarkhan, R.P., 1992, "Analysis and Modeling of Fission Product Release from Various Uranium-Aluminum Plate-Type Reactors Fuels," Nuclear Safety 33 1):6-22.

U.S. Department of Energy (DOE), 1994, Airborne Release Fractions / Rates and Respirable Fractions at DOE Nonreactor Nuclear Facilities, DOE-STD-3010-94, Office of Scientific and Technical Information, Oak Ridge, Tenn.

U.S. Department of Energy, 1995, Office of Waste Management Programmatic Environmental Impact Statement, Draft, Washington, D.C.

U.S. Nuclear Regulatory Commission (NRC), 1977a, "Assumptions Used for Evaluating the Potential Radiological Consequences of Accidental Nuclear Criticality in a Fuel Reprocessing Plant," NRC Regulatory Guide 3.33.

U.S. Nuclear Regulatory Commission, 1977b, "Assumptions Used for Evaluating the Potential Radiological Consequences of Accidental Nuclear Criticality in a Plutonium Processing and Fuel Fabrication Plant," NRC Regulatory Guide 3.35.

U.S. Nuclear Regulatory Commission, 1977c, "Assumptions Used for Evaluating Radiological Consequences of Accidental Nuclear Criticality in a Uranium Fuel Fabrication Plant," NRC Regulatory Guide 3.34 . 
U.S. Nuclear Regulatory Commission, 1988, Nuclear Fuel Cycle Facility Accident Analysis Handbook, NUREG-1320, Washington, D.C., May.

Walker, E., 1987, A Summary of Parameters Affecting the Release and Transport of Radioactive Material from an Unplanned Incident, BNFO-81-2, Bechtel Nuclear Fuels, San Francisco, Calif., Sept.

Westinghouse Hanford Company, 1993, Preliminary Safety Analysis Report for Hanford Waste Vitrification Plant, WHC-SD-HWV-PSAR-001, rev. 1, (draft), Richland, Wash.

Westinghouse Savannah River Company (WSRC), 1990, Safety Analysis - 200-S Area Savannah River Site Defense Waste Processing Facility Operations (U), DPSTSA-200-10, rev. 1 SUP-20, Aiken, S.C., Feb.

Westinghouse Savannah River Company, 1991, Support Facilities Descriptions for the New Production Reactor at Savannah River, Volume 1, Heavy Water Reactor (U), WSRC-RP-89263, vol. 1, version 4, Aiken, S.C.

Westinghouse Savannah River Company, 1993, Final Safety Analysis, Defense Waste Processing Facility. Chapter 9, Analysis of Operation, DPSTA-200-10 SUP.20 rev. 9, Westinghouse Savannah River Co., Aiken, S.C.

WSRC. See Westinghouse Savannah River Co. 
APPENDIX E:

REFERENCE DATA ON NATURAL PHENOMENA FREQUENCIES AND RELATED DESIGN SPECIFICATIONS OF DOE FACILITIES 


\section{CONTENTS}

NOTATION . . . . . . . . . . . . .

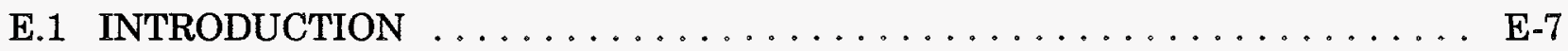

E.2 REFERENCES . . . . . . . . . . . . . . . . . . . . . . . E-13

\section{FIGURE}

E.1 Relationship among Hazard Class/Category, SSC Performance Category, and Pertinent DOE Orders and Standards . . . . . . . . E E

\section{TABLES}

E.1 Natural Phenomena Hazards Performance Goals for Structures,

Systems, and Components . . E-7

E.2 Natural Phenomena Frequency and Intensity Data for DOE Sites . E-9 


\section{NOTATION}

The following is a list of acronyms, initialisms, and abbreviations (including units of measure) used in this appendix.

\section{ACRONYMS, INITIALISMS, AND ABBREVIATIONS}

$\begin{array}{ll}\text { ANL-E } & \text { Argonne National Laboratory-East } \\ \text { ANL-W } & \text { Argonne National Laboratory-West } \\ \text { BNL } & \text { Brookhaven National Laboratory } \\ \text { CFA } & \text { Central Facilities Area } \\ \text { CPP } & \text { Chemical Processing Plant } \\ \text { DOE } & \text { U.S. Department of Energy } \\ \text { DWPF } & \text { Defense Waste Processing Facility } \\ \text { ETEC } & \text { Energy Technology Engineering Center } \\ \text { FEMP } & \text { Fernald Environmental Management Project } \\ \text { HWHF } & \text { High-Level Waste Handling Facility } \\ \text { INEL } & \text { Idaho National Engineering Laboratory } \\ \text { KCP } & \text { Kansas City Plant } \\ \text { LANL } & \text { Los Alamos National Laboratory } \\ \text { LBL } & \text { Lawrence Berkeley National Laboratory } \\ \text { LLNL } & \text { Lawrence Livermore National Laboratory } \\ \text { NTS } & \text { Nevada Test Site } \\ \text { ORR } & \text { Oak Ridge National Laboratory } \\ \text { PBF } & \text { Power Burst Facility } \\ \text { PGDP } & \text { Paducah Gaseous Diffusion Plant } \\ \text { PORTS } & \text { Portsmouth Gaseous Diffusion Plant } \\ \text { RFETS } & \text { Rocky Flats Environmental Technology Site } \\ \text { RWMC } & \text { Radioactive Waste Management Complex } \\ \text { RWMS } & \text { Radioactive Waste Management Site } \\ \text { SLAC } & \text { Stanford Linear Accelerator Center } \\ \text { SNL-CA } & \text { Sandia National Laboratories (California) } \\ \text { SNL-NM } & \text { Sandia National Laboratories (New Mexico) } \\ \text { SRS } & \text { Savannah River Site } \\ \text { SSC } & \text { system, structure, and component } \\ \text { TA } & \text { Technical Area } \\ \text { WIPP } & \text { Waste Isolation Pilot Plant } \\ & \end{array}$

\section{UNITS OF MEASURE}

$\begin{array}{ll}\mathrm{ft} & \text { foot (feet) } \\ \mathrm{g} & \operatorname{gram}(\mathrm{s}) \\ \mathrm{m} & \text { meter(s) } \\ \mathrm{m}^{3} & \text { cubic meter(s) } \\ \mathrm{mi} / \mathrm{h} & \text { mile(s) per hour }\end{array}$




\section{APPENDIX E:}

\section{REFERENCE DATA ON NATURAL PHENOMENA FREQUENCIES AND RELATED DESIGN SPECIFICATIONS OF DOE FACHITIES}

\section{E.1 INTRODUCTION}

This appendix provides data developed to correlate the magnitude and frequencies of severe natural phenomena that may challenge the facilities at U.S. Department of Energy (DOE) waste management sites. Natural phenomena frequencies were obtained following a two-step process:

1. Performance goals for structures, systems, and components (SSCs) published in DOE 5480.28 (DOE 1993) and summarized in a revised nomenclature in the DOE standard for performance categorization (DOE 1992) are shown in Figure E.1 and summarized in Table E.1 Figure E.1 shows the equivalency between performance categories and hazard categories.

2. The frequencies of varying levels of intensity for natural phenomena at the DOE sites were compiled from the DOE Natural Phenomena Hazards Modeling Project (Coats and Murray 1984, 1985; Savy and Murray 1985). The annual frequencies of exceedance associated with the performance goals were then compared with the published sitespecific hazards data to map natural phenomena loadings with these frequencies. The results are shown in Table E.2.

TABLE E.1 Natural Phenomena Hazards Performance Goals for Systems, Structures, and Components

\begin{tabular}{lcccc}
\hline & High & Moderate & Low \\
Hazard & Hazard \\
Hazard Category & 1 & 2 & $\begin{array}{c}\text { Hazard } \\
3\end{array}$ & $\begin{array}{c}\text { General } \\
\text { Use } \\
4\end{array}$ \\
\hline $\begin{array}{l}\text { Performance goal (mean annual } \\
\text { probability of exceedance of } \\
\text { acceptable behavior limits) }\end{array}$ & $10^{-5}$ & $10^{-4}$ & $5 \times 10^{-4}$ & $10^{-3}$ \\
\hline
\end{tabular}




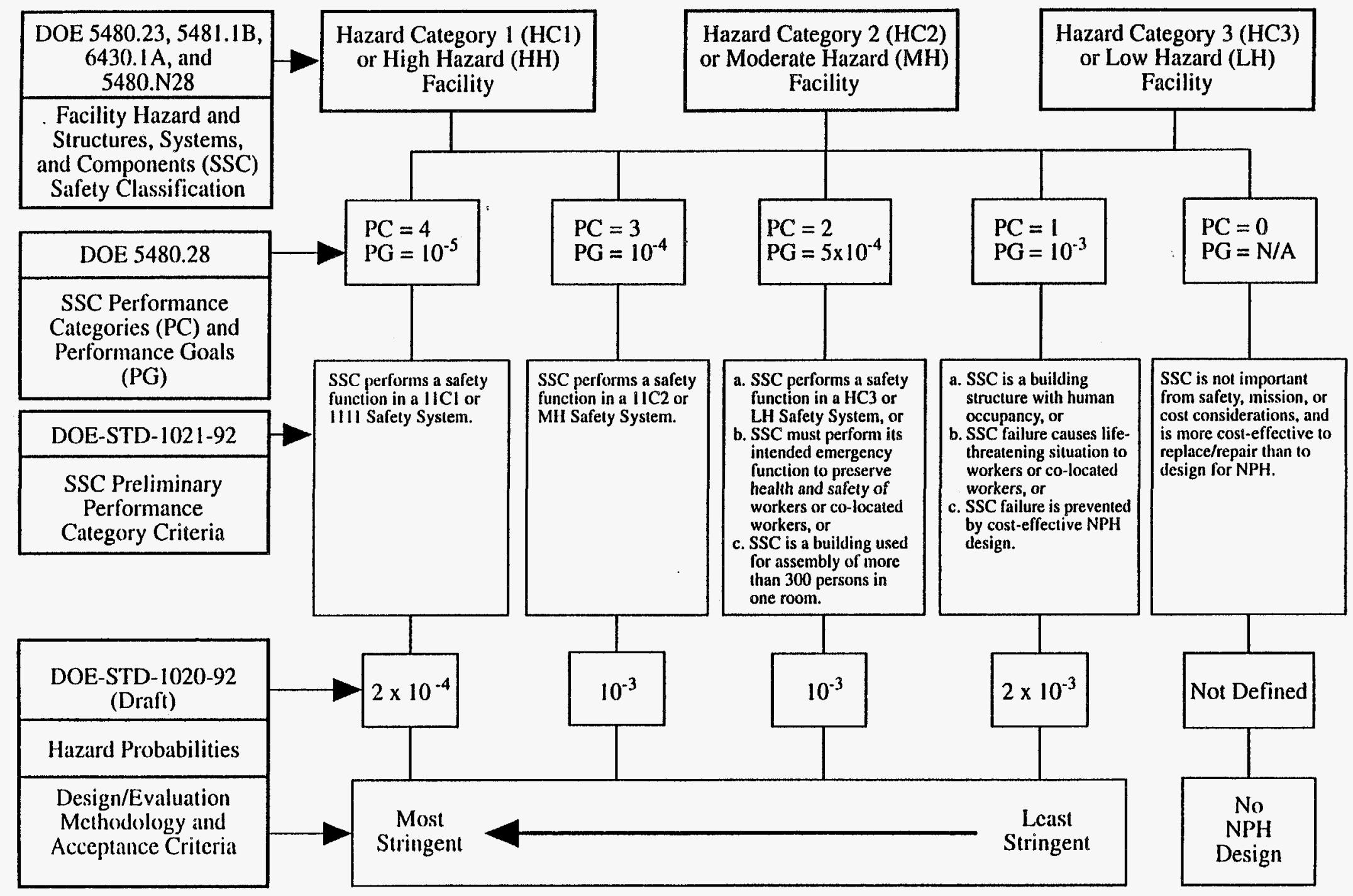

FIGURE E.1 Relationship among Hazard Class/Category, SSC Performance Category and Pertinent DOE Orders and Standards 
TABLE E.2 Natural Phenomena Frequency and Intensity Data for DOE Sites ${ }^{a}$

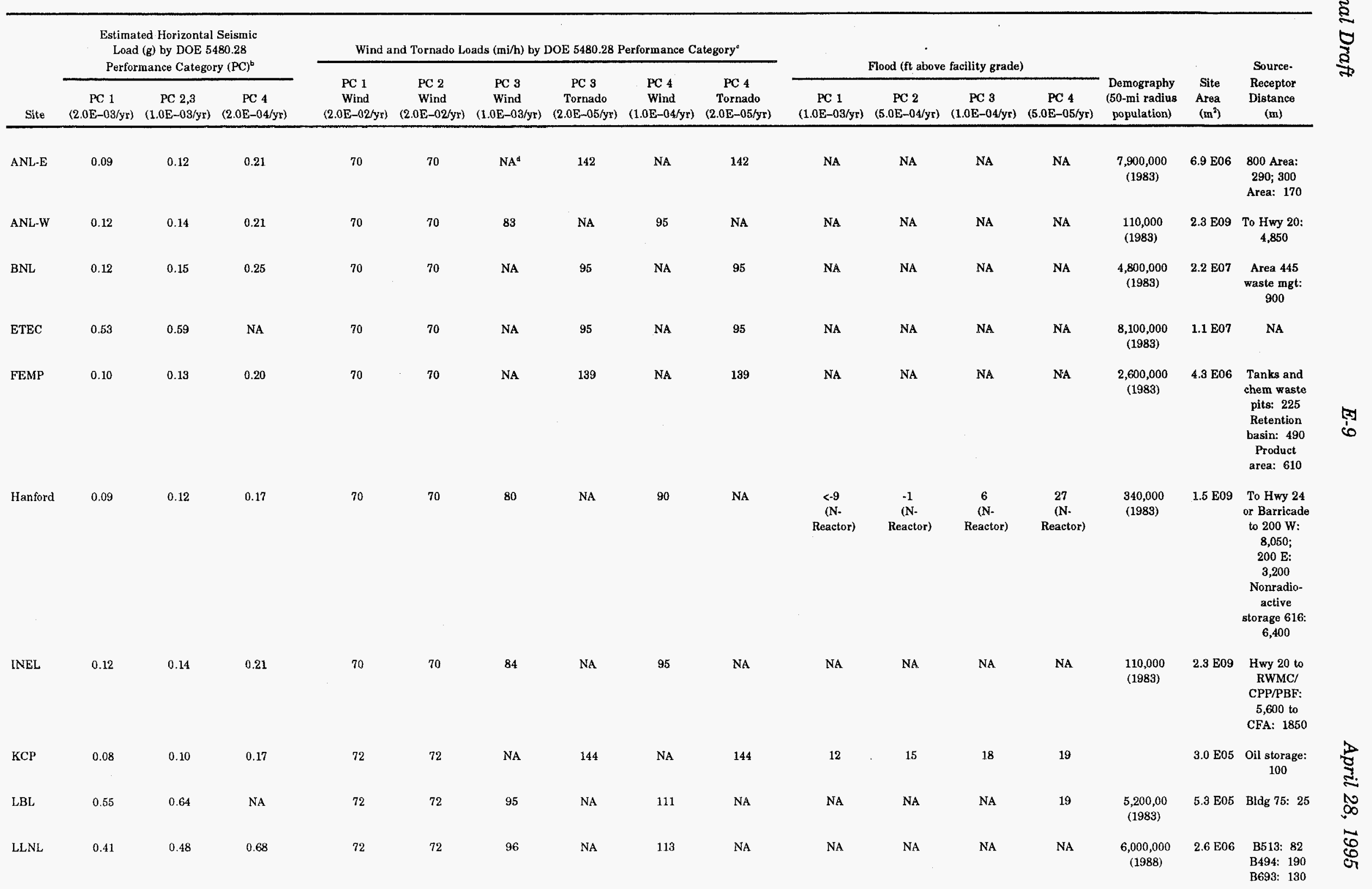


TABLE E.2 (Cont.)

\begin{tabular}{|c|c|c|c|c|c|c|c|c|c|c|c|c|c|c|c|c|}
\hline \multirow[b]{2}{*}{ Site } & \multicolumn{3}{|c|}{$\begin{array}{l}\text { Estimated Horizontal Seismic } \\
\text { Load (g) by DOE 5480.28 } \\
\text { Performance Category (PC) }\end{array}$} & \multicolumn{6}{|c|}{ Wind and Tornado Loads (mi/h) by DOE 5480.28 Performance Category } & \multicolumn{4}{|c|}{ Flood (ft above facility grade) } & \multirow[b]{2}{*}{$\begin{array}{c}\text { Demography } \\
\text { (50-mi radius } \\
\text { population) }\end{array}$} & \multirow[b]{2}{*}{$\begin{array}{r}\text { Site } \\
\text { Area } \\
\left(\mathbf{m}^{2}\right)\end{array}$} & \multirow[b]{2}{*}{$\begin{array}{c}\text { Source- } \\
\text { Receptor } \\
\text { Distance } \\
\text { (m) }\end{array}$} \\
\hline & $\begin{array}{c}\text { PC 1 } \\
(2.0 \mathrm{E}-03 / y r)\end{array}$ & $\begin{array}{c}\text { PC 2,3 } \\
(1,0 \mathrm{E}-03 / \mathrm{yr})\end{array}$ & $\begin{array}{c}\mathrm{PC} \mathrm{4} \\
(2.0 \mathrm{E}-04 / \mathrm{yr})\end{array}$ & $\begin{array}{c}\mathrm{PC} 1 \\
\text { Wind } \\
(2.0 \mathrm{E}-02 / \mathrm{yr})\end{array}$ & $\begin{array}{c}\text { PC 2 } \\
\text { Wind } \\
(2.0 \mathrm{E}-02 / y x)\end{array}$ & $\begin{array}{c}\text { PC } 3 \\
\text { Wind } \\
(1.0 \mathrm{E}-03 / \mathrm{yr})\end{array}$ & $\begin{array}{c}\text { PC } 3 \\
\text { Tornado } \\
(2.0 \mathrm{E}-05 / \mathrm{yr})\end{array}$ & $\begin{array}{c}\text { PC 4 } \\
\text { Wind } \\
(1,0 \mathrm{E}-04 / \mathrm{yr})\end{array}$ & $\begin{array}{c}\text { PC 4 } \\
\text { Tornado } \\
(2.0 \mathrm{E}-05 / \mathrm{yr})\end{array}$ & $\begin{array}{c}\text { PC } 1 \\
(1.0 \mathrm{E}-03 / \mathrm{yr})\end{array}$ & $\begin{array}{c}\text { PC 2 } \\
(5.0 \mathrm{E}-04 / \mathrm{yr})\end{array}$ & $\begin{array}{c}\text { PC 3 } \\
(1.0 \mathrm{E}-04 / \mathrm{yr})\end{array}$ & $\begin{array}{c}\mathrm{PC} \dot{4} 4 \\
(5.0 \mathrm{E}-05 / \mathrm{yr})\end{array}$ & & & \\
\hline $\begin{array}{l}\text { LLNL, } \\
\text { Site } 300\end{array}$ & 0.32 & 0.38 & 0.56 & 80 & 80 & 104 & $\mathrm{NA}$ & 125 & $\mathrm{NA}$ & NA & $\mathrm{NA}$ & NA & NA & NA & $\begin{array}{r}2.9 \\
\text { E07 }\end{array}$ & B883: 200 \\
\hline LANL & 0.18 & 0.22 & 0.38 & 77 & 77 & 93 & NA & 107 & $\mathrm{NA}$ & $\begin{array}{c}1 \\
\text { (TA-41) }\end{array}$ & $\begin{array}{c}2 \\
\text { (TA-41) }\end{array}$ & $\begin{array}{c}3 \\
\text { (TA-41) }\end{array}$ & $\begin{array}{c}5 \\
\text { (TA-41) }\end{array}$ & $\begin{array}{l}160,000 \\
(1983)\end{array}$ & $\begin{array}{r}1.1 \\
\text { E08 }\end{array}$ & $\begin{array}{c}\text { TA-50 waste } \\
\text { mgt: } 1,800 ; \\
\text { TA-54: } \\
\text { 2,600; TA-3: } \\
900\end{array}$ \\
\hline Mound & 0.12 & 0.15 & 0.23 & 73 & 73 & NA & 136 & $\mathrm{NA}$ & 136 & -5 & -3 & -1 & 0 & $\begin{array}{c}3,400,000 \\
(1983)\end{array}$ & $\begin{array}{r}1.2 \\
E 06\end{array}$ & $\begin{array}{c}\text { Main area: } \\
\text { 120; PP } \\
\text { area: } 60 \\
\text { Test fire } \\
\text { area: } 230\end{array}$ \\
\hline NTS & 0.21 & 0.27 & 0.46 & 72 & 72 & 87 & $\mathrm{NA}$ & 100 & NA & NA & NA & NA & NA & $\begin{array}{l}4,600 \\
(1983)\end{array}$ & $\begin{array}{r}3.5 \\
\text { E09 }\end{array}$ & $\begin{array}{c}\text { Area 5 } \\
\text { RWMS: } \\
20,300 \\
\text { Area 3 } \\
\text { RWMS: } \\
41,300 \\
\text { R-MAD: } \\
17,500 \\
\text { Area } 26 \\
\text { Shaft: } \\
17,000\end{array}$ \\
\hline ORR & 0.15 & 0.19 & 0.32 & 70 & 70 & NA & 113 & NA & 113 & NA & NA & $\mathrm{NA}$ & NA & $\begin{array}{l}840,000 \\
(1983)\end{array}$ & $1.2 \mathrm{E} 07$ & \\
\hline K-25 & 0.15 & 0.19 & 0.32 & 70 & 70 & NA & 113 & NA & 113 & NA & NA & NA & NA & $\begin{array}{l}840,000 \\
(1983)\end{array}$ & $\begin{array}{l}6.1 \\
\text { E06 }\end{array}$ & \\
\hline $\mathrm{Y}-12$ & 0.15 & 0.19 & 0.32 & 70 & 70 & NA & 113 & NA & 113 & $\mathrm{NA}$ & $\mathrm{NA}$ & NA & NA & $\begin{array}{l}840,000 \\
(1983)\end{array}$ & $\begin{array}{l}3.3 \\
\text { E06 }\end{array}$ & \\
\hline PGDP & 0.33 & 0.45 & NA & 70 & 70 & $\mathrm{NA}$ & 144 & NA & 144 & NA & NA & $\mathrm{NA}$ & NA & $\begin{array}{l}500,000 \\
(1983)\end{array}$ & $1.4 \mathrm{E} 07$ & \\
\hline Pantex & 0.08 & 0.10 & 0.17 & 78 & 78 & $\mathrm{NA}$ & 132 & NA & 132 & $\mathrm{NA}$ & NA & $\mathrm{NA}$ & NA & $\begin{array}{l}259,300 \\
(1980)\end{array}$ & $\begin{array}{r}6.5 \\
\text { E07 }\end{array}$ & $\begin{array}{c}\text { Zone 4 } \\
\text { burial: } \\
1,800 \\
\text { Zone } 13 \\
\text { sewage } \\
\text { treatment: } \\
110\end{array}$ \\
\hline Pinellas & 0.04 & 0.05 & 0.09 & 93 & 93 & 130 & $\mathrm{NA}$ & 150 & $\mathrm{NA}$ & -2 & -1 & 5 & 17 & $\begin{array}{c}2,000,000 \\
(1983)\end{array}$ & $\begin{array}{r}4.0 \\
\text { E05 }\end{array}$ & \\
\hline
\end{tabular}


TABLE E.2 (Cont.)

\begin{tabular}{|c|c|c|c|c|c|c|c|c|c|c|c|c|c|c|c|c|}
\hline \multirow[b]{2}{*}{ Site } & \multicolumn{3}{|c|}{$\begin{array}{l}\text { Estimated Horizontal Seismic } \\
\text { Load (g) by DOE } 5480.28 \\
\text { Performance Category (PC) }\end{array}$} & \multicolumn{6}{|c|}{ Wind and Tornado Loads (mi/h) by DOE 5480.28 Performance Category } & \multicolumn{4}{|c|}{ Flood (ft above facility grade) } & \multirow[b]{2}{*}{$\begin{array}{c}\text { Demography } \\
\text { (50-mi radius } \\
\text { population) }\end{array}$} & \multirow[b]{2}{*}{$\begin{array}{l}\text { Site } \\
\text { Area } \\
\left(\mathrm{m}^{2}\right) \\
\end{array}$} & \multirow[b]{2}{*}{$\begin{array}{l}\text { Source- } \\
\text { Receptor } \\
\text { Distance } \\
\text { (m) }\end{array}$} \\
\hline & $\begin{array}{c}\text { PC } 1 \\
(2.0 \mathrm{E}-03 / \mathrm{yr})\end{array}$ & $\begin{array}{c}\mathrm{PC} 2,3 \\
(1.0 \mathrm{E}-03 / \mathrm{yr})\end{array}$ & $\begin{array}{c}\mathrm{PC} 4 \\
(2.0 \mathrm{E}-04 / \mathrm{yr})\end{array}$ & $\begin{array}{c}\mathrm{PC} 1 \\
\text { Wind } \\
(2.0 \mathrm{E}-02 / \mathrm{yr})\end{array}$ & $\begin{array}{c}\text { PC } 2 \\
\text { Wind } \\
(2.0 \mathrm{E}-02 / \mathrm{yr})\end{array}$ & $\begin{array}{c}\text { PC 3 } \\
\text { Wind } \\
(1,0 \mathrm{E}-03 / \mathrm{yr})\end{array}$ & $\begin{array}{c}\text { PC 3 } \\
\text { Tornado } \\
(2.0 \mathrm{E}-05 / \mathrm{yr})\end{array}$ & $\begin{array}{c}\text { PC 4 } \\
\text { Wind } \\
(1.0 \mathrm{E}-04 / \mathrm{yr})\end{array}$ & $\begin{array}{c}\mathrm{PC} 4 \\
\text { Tornado } \\
(2.0 \mathrm{E}-05 / \mathrm{yr})\end{array}$ & $\begin{array}{c}\mathrm{PC} 1 \\
(1.0 \mathrm{E}-03 / y \mathrm{r})\end{array}$ & $\begin{array}{c}\mathrm{PC} 2 \\
(5.0 \mathrm{E}-04 / \mathrm{yr})\end{array}$ & $\begin{array}{c}\text { PC 3 } \\
(1.0 \mathrm{E}-04 / \mathrm{yr})\end{array}$ & $\begin{array}{c}\mathrm{PC} 4 \\
(5.0 \mathrm{E}-05 / \mathrm{yr})\end{array}$ & & & \\
\hline PORTS & 0.08 & 0.11 & 0.17 & 70 & 70 & NA & 110 & NA & 110 & NA & NA & $\mathrm{NA}$ & $\mathrm{NA}$ & $\begin{array}{l}600,000 \\
(1983)\end{array}$ & $\begin{array}{r}1.5 \\
\text { E07 }\end{array}$ & $\begin{array}{c}\text { X-749 } \\
\text { storage: } \\
700 ; X-705 \\
\text { decon: } \\
\text { 1,000; } \\
\text { X-611 water } \\
\text { treatment: } \\
1,400\end{array}$ \\
\hline RFETS & 0.13 & 0.15 & 0.21 & 109 & 109 & 138 & NA & 161 & NA & 4 & 5 & 6 & 8 & $\begin{array}{c}1,800,000 \\
(1983)\end{array}$ & $\begin{array}{r}2.9 \\
\text { E07 }\end{array}$ & $\begin{array}{c}\text { B664 waste } \\
\text { storage \& } \\
\text { shipping: } \\
1,280\end{array}$ \\
\hline SNL-NM & 0.17 & 0.22 & 0.38 & 78 & 78 & 93 & NA & 107 & NA & & No credible & flood hazard & & $\begin{array}{l}450,000 \\
(1988)\end{array}$ & $\begin{array}{r}1.1 \\
\text { E07 }\end{array}$ & $\begin{array}{c}\text { TA II burial: } \\
\text { 490; TA II } \\
\text { radwaste } \\
\text { storage: } 820 \\
\text { TA III } \\
\text { mixed waste } \\
\text { burial: } 850 \\
\text { TA III waste } \\
\text { mgt } \\
\text { complex/ } \\
\text { chem waste } \\
\text { burial: } 120 \\
\text { TA V waste } \\
\text { mgt } \\
\text { complex: } \\
190\end{array}$ \\
\hline SNL-CA & 0.41 & 0.48 & 0.68 & 72 & 72 & 96 & NA & 113 & $\mathrm{NA}$ & 2.5 & 3 & 4 & 5 & $\begin{array}{c}6,000,000 \\
(1988)\end{array}$ & $\begin{array}{c}1.7 \\
\text { E06 }\end{array}$ & B961: 530 \\
\hline SRS & 0.08 & 0.11 & 0.19 & 78 & 78 & $\mathrm{NA}$ & 137 & NA & 137 & & NA & $\mathrm{NA}$ & $\mathrm{NA}$ & $\begin{array}{l}555,100 \\
(1988)\end{array}$ & $\begin{array}{r}8.4 \\
\text { E08 }\end{array}$ & $\begin{array}{c}\text { 100/200 } \\
\text { areas: } \\
\text { DWPF/ } \\
\text { tanks C, RX, } \\
\text { KRX, PARX, } \\
\text { LLW burial: } \\
\text { 10,000; } 300 \\
\text { Area: } 1,600\end{array}$ \\
\hline
\end{tabular}


TABLE E.2 (Cont.)

Stimated Horizontal Seismic

Performance Category (PC)

\begin{tabular}{|c|c|c|c|}
\hline Site & $\begin{array}{c}\mathrm{PC} 1 \\
(2.0 \mathrm{E}-03 / \mathrm{yr})\end{array}$ & $\begin{array}{c}\mathrm{PC} 2,3 \\
(1.0 \mathrm{E}-03 / \mathrm{yr})\end{array}$ & $\begin{array}{c}\mathrm{PC} 4 \\
(2.0 \mathrm{E}-04 / \mathrm{yr})\end{array}$ \\
\hline
\end{tabular}

WIPP $\quad$ NA

NA

$\mathrm{NA}$

$\begin{array}{llllll}(2.0 \mathrm{E}-02 / y \mathrm{r}) & (2.0 \mathrm{E}-02 / \mathrm{yr}) & (1.0 \mathrm{E}-03 / y \mathrm{r}) & (2.0 \mathrm{E}-05 / \mathrm{yr}) & (1.0 \mathrm{E}-04 / \mathrm{yr}) & (2.0 \mathrm{E}-05 / \mathrm{yr})\end{array}$

\begin{tabular}{|c|c|c|c|c|c|c|}
\hline \multicolumn{4}{|c|}{ Flood (ft above facility grade) } & \multirow{2}{*}{$\begin{array}{c}\text { Demography } \\
\text { (50 mi radius } \\
\text { population) }\end{array}$} & \multirow{2}{*}{$\begin{array}{l}\text { Site } \\
\text { Area } \\
\left(\mathrm{m}^{2}\right)\end{array}$} & \multirow{2}{*}{$\begin{array}{l}\text { Source- } \\
\text { Receptor } \\
\text { Distance } \\
\text { (m) }\end{array}$} \\
\hline $\begin{array}{c}\mathrm{PC} 1 \\
(1.0 \mathrm{E}-03 / y \mathrm{r})\end{array}$ & $\begin{array}{c}\mathrm{PC} 2 \\
(5.0 \mathrm{E}-04 / \mathrm{yr})\end{array}$ & $\begin{array}{c}\text { PC 3 } \\
(1.0 \mathrm{E}-04 / \mathrm{ys})\end{array}$ & $\begin{array}{c}\mathrm{PC} 4 \\
(5.0 \mathrm{E}-05 / \mathrm{yr})\end{array}$ & & & \\
\hline $\mathrm{NA}$ & $\mathrm{NA}$ & NA & $\mathrm{NA}$ & $\begin{array}{l}113,000 \\
(1990)\end{array}$ & $\begin{array}{r}5.9 \\
\text { E06 }\end{array}$ & $\begin{array}{c}\text { B411 waste } \\
\text { handling \& } \\
\text { B474 hazard } \\
\text { waste } \\
\text { storage: } 950\end{array}$ \\
\hline
\end{tabular}

$\begin{array}{ccccc}\text { Wind } & \text { PC 3 } & \text { PC 3 } & \text { PC 4 } & \text { PC 4 } \\ \text { Wind } & \text { Tornado } & \text { Wind } & \text { Tornado }\end{array}$

Wind and T'ornado Loads (mi/h) by DOE 5480.28 Performance Category

$\begin{array}{lllclc}\text { PC } 1 & \text { PC } 2 & \text { PC } 3 & \text { PC } 3 & \text { PC 4 } & \text { PC 4 } \\ \text { Wind } & \text { Wind } & \text { Wind } & \text { Tornado } & \text { Wind } & \text { Tornado }\end{array}$

80

80

NA

$<183$

NA
$>183$

- Abbreviations: ANL-E = Argonne National Laboratory-East, ANL-W $=$ A

W Argonne National Laboratory-West, BNL $=$ Brookhaven National Laboratory, CFA $=$ Central Facilities Area, CPP $=$ Chemical Processing Plant, DWPF $=$ Defense Waste Processing Facility, ETEC = Energy Technology Engineering Center, FEMP = Fernald Environmental Management Project, INEL $=$ Idaho National Engineering Laboratory, KCP = Kansas City Plant, LANL $=$ Los Alamos National Laboratory, LBL = Lawrence Berkeley National Laboratory, LLNL $=$ Lawrence Livermore National Laboratory, NTS = Nevada Test Site, ORR = Oak Ridge National Laboratory, PBF $=$ Power Burst Facility, PGDP $=$ Paducah Gaseou

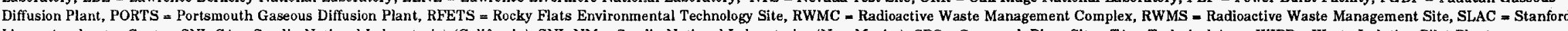
Linear Accelerator Center, SNL $-C A=$ Sandia National Laboratories (California), SNL-NM $=$ Sandia National Laboratories (New Mexico), SRS $=$ Savannah River Site, TA $=$ Technical Area, WIPP $=$ Waste Isolation Pilot Plant

brom Table 4-4, Kennedy et al. (1990)

c From Table 5-3, Kennedy et al. (1990)

d $\quad \mathrm{NA}=$ not applicable. 


\section{E.2 REFERENCES}

Coats, D.W., and R.C. Murray, 1984, Natural Phenomena Hazards Modeling Project: Seismic Models for Department of Energy Sites, UCRL-53582, rev. 1, Lawrence Livermore National Laboratory, Livermore, Calif.

Coats, D.W., and R.C. Murray, 1985, Natural Phenomena Hazards Modeling Project: Wind/ Tornado Hazard Models for Department of Energy Sites, UCRL-53526, rev. 1, Lawrence Livermore National Laboratory, Livermore, Calif.

Kennedy, R.P., et al., 1990, Design and Evaluation Guidelines for Department of Energy Facilities Subjected to Natural Phenomena Hazards, UCRL-15910, Lawrence Livermore National Laboratory, Livermore, Calif.

Savy, J.B., and R.C. Murray, 1985, Natural Phenomena Hazards Modeling Project: Flood Hazard Models for Department of Energy Sites, UCRL-53851, Lawrence Livermore National Laboratory, Livermore, Calif.

U.S. Department of Energy, 1992, "Natural Phenomena Hazards Performance Categorization Criteria for Structures, Systems, and Components," DOE-STD-1021-92.

U.S. Department of Energy, 1993, "Natural Phenomena Hazards Mitigation," DOE Order 5480.28. 


\section{APPENDIX F:}

EVALUATION OF AIR CRASH ACCIDENTS FOR U.S. DEPARTMENT

OF ENERGY WASTE MANAGEMENT FACILITIES 


\section{CONTENTS}

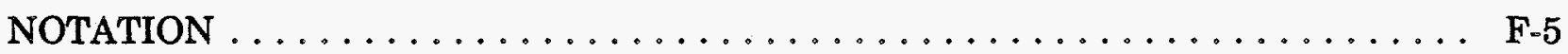

F.1 BACKGROUND $\ldots \ldots \ldots \ldots \ldots \ldots \ldots \ldots \ldots \ldots \ldots \ldots \ldots \ldots$

F.2 METHODOLOGY $\ldots \ldots \ldots \ldots \ldots \ldots \ldots \ldots \ldots \ldots \ldots \ldots \ldots \ldots$

F.2.1 Crash Probability Estimates $\ldots \ldots \ldots \ldots \ldots \ldots \ldots \ldots \ldots \ldots \ldots \ldots$. . . . . . . .

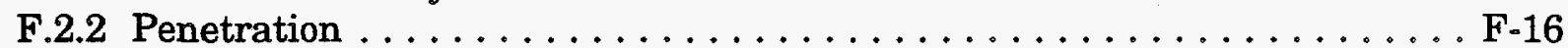

F.2.3 Fire . . . . . . . . . . . . . . . . . . . . . . F-17

F.2.4 Presence of Radioactive Material $\ldots \ldots \ldots \ldots \ldots \ldots \ldots \ldots$. . . . . . . . F

F.3 SUMMARY OF AIRCRAFT CRASH FREQUENCIES PER UNIT

OF LAND SURFACE $\ldots \ldots \ldots \ldots \ldots \ldots \ldots \ldots \ldots \ldots \ldots \ldots \ldots$

F.4 AIRCRAFT CRASH FREQUENCY FOR WM PEIS FACILITIES $\ldots \ldots \ldots \ldots$. . F-18

F.4.1 Facility Target Area . . . . . . . . . . . . . . . . . . . . F-19

F.4.2 Frequency of Aircraft Crashes Against Facilities at DOE Sites . . . . . . F-21

F.5 REFERENCES $\ldots \ldots \ldots \ldots \ldots \ldots \ldots \ldots \ldots \ldots \ldots \ldots \ldots \ldots \ldots \ldots$

\section{FIGURES}

F.1 Generic Representation of Takeoff and Landing Sectors . . . . . . . . . . . F-9

F.2 Facility Target Area . . . . . . . . . . . . . . . . . . . . . F-20

\section{TABLES}

F.1 Probabilities of a Fatal Crash $\ldots \ldots \ldots \ldots \ldots \ldots \ldots \ldots \ldots \ldots \ldots$

F.2 Principal DOE Waste Management Sites $\ldots \ldots \ldots \ldots \ldots \ldots \ldots \ldots \ldots$

F.3 Airports near DOE Sites and their Potentials to Increase Aircraft Accident Frequencies . . . . . . . . . . . . . . . . . F F-13

F.4 Estimated Annual Overflight Frequencies of DOE Sites . . . . . . . . . . . F-14

F.5 Estimated Annual Crash Probabilities at DOE Sites from Commercial Aviation Operations at Nearby Airports . . . . . . . . . . . . . . F-15

F.6 Estimated Annual Federal Airway Commercial Crash Probabilities . . . . . . F-15 


\section{TABLES (Cont.)}

F.7 Estimated Annual Crash Probabilities at DOE Sites from General Aviation Operations at Nearby Airports . . . . . . . . . . . . . . F-17

F.8 General Aviation Building Penetration Probabilities $\ldots \ldots \ldots \ldots \ldots \ldots \ldots$ F-17

F.9 Summary of Annual Aircraft Crash Frequencies for DOE Sites . . . . . . . F-18

F.10 Summary of Annual Aircraft Crash Frequency Per Square Mile Grouped into APLL and APLS Crashes . . . . . . . . . . . F F-19

F.11 Effective Area Estimates for LLW, LLMW, TRUW, HLW,

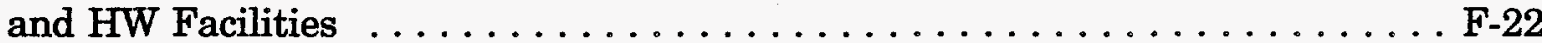

F.12 Airplane Impacts Initiating Event Frequency: LLW Storage . . . . . . . . F-23

F.13 Airplane Impacts Initiating Event Frequency: LLW

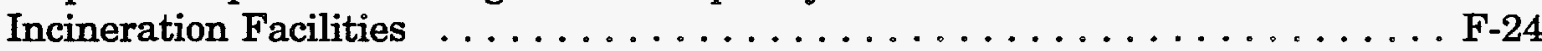

F.14 Airplane Impacts Initiating Event Frequency: HLW Facilities . . . . . . . F-24

F.15 Airplane Impacts Initiating Event Frequency: HW Storage Facilities . . . . . F-25

F.16 Airplane Impacts Initiating Event Frequency: HW Treatment Facilities . . . . . . . . . . . . . . . . . . . . . . . . F-25

F.17 Airplane Impacts Initiating Event Frequency: LLMW

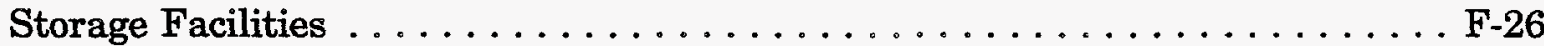

F.18 Airplane Impacts Initiating Event Frequency: LLMW Treatment Facilities . . . . . . . . . . . . . . . . . . . . . . . F-26

F.19 Airplane Impacts Initiating Event Frequency: TRUW Storage Facilities

F.20 Airplane Impacts Initiating Event Frequency: TRUW Treatment Facilities . 


\section{NOTATION}

The following is a list of the acronyms, initialisms, and abbreviations (including units of measure) used in this appendix.

\section{ACRONYMS, INITIALISMS, AND ABBREVIATIONS}

$\begin{array}{ll}\text { AEC } & \text { Atomic Energy Commission } \\ \text { ANL-E } & \text { Argonne National Laboratory-East } \\ \text { APLL } & \text { large aircraft crash } \\ \text { APLS } & \text { small aircraft crash } \\ \text { BNL } & \text { Brookhaven National Laboratory } \\ \text { CFR } & \text { Code of Federal Regulations } \\ \text { DOE } & \text { U.S. Department of Energy } \\ \text { DST } & \text { double-shell tank } \\ \text { EM } & \text { Environmental Management } \\ \text { ETEC } & \text { Energy Technology Engineering Center } \\ \text { FEMP } & \text { Fernald Environmental Management Project } \\ \text { Fermi } & \text { Fermi National Accelerator Laboratory } \\ \text { Hanford } & \text { Hanford Site } \\ \text { HLW } & \text { high-level waste } \\ \text { HW } & \text { hazardous waste } \\ \text { INEL } & \text { Idaho National Engineering Laboratory } \\ \text { KAPL-S } & \text { Knolls Atomic Power Laboratory (Schenectady) } \\ \text { KCP } & \text { Kansas City Plant } \\ \text { LANL } & \text { Los Alamos National Laboratory } \\ \text { LBL } & \text { Lawrence Berkeley National Laboratory } \\ \text { LLMW } & \text { low-level mixed waste } \\ \text { LLNL } & \text { Lawrence Livermore National Laboratory } \\ \text { LLW } & \text { low-level waste } \\ \text { Middlesex } & \text { Middlesex Sampling Plant } \\ \text { Mound } & \text { Mound Plant } \\ \text { NPIAS } & \text { National Plan for Integrated Airport Systems } \\ \text { NRC } & \text { U.S. Nuclear Regulatory Commission } \\ \text { NTS } & \text { Nevada Test Site } \\ \text { NTSB } & \text { National Transportation Safety Board } \\ \text { ORR } & \text { Oak Ridge National Laboratory } \\ \text { Pantex } & \text { Pantex Plant } \\ \text { PEIS } & \text { Programmatic Environmental Impact Statement } \\ \text { PGDP } & \text { Paducah Gaseous Diffusion Plant } \\ \text { PORTS } & \text { Portsmouth Gaseous Diffusion Plant } \\ \text { RFETS } & \text { Rocky Flats Environmental Technology Site } \\ \text { SAIC } & \text { Science Applications International Corporation } \\ \text { SNL-NM } & \text { Sandia National Laboratories (New Mexico) } \\ \text { SRS } & \text { Savannah River Site } \\ & \end{array}$


TRUW transuranic waste

WAC world aeronautical chart

WIPP Waste Isolation Pilot Plant

WM Waste Management

WVDP West Valley Demonstration Project

\section{UNITS OF MEASURE}
cm centimeter(s)
$\mathrm{ft}$ foot(feet)
in. inch(es)
km kilometer(s)
m meter(s)
$\mathrm{m}^{2} \quad$ square meter(s)
mi mile(s)
$\mathrm{mi}^{2} \quad$ square mile(s)
yr year(s) 


\section{APPENDIX F:}

\section{EVALUATION OF AIR CRASH ACCIDENTS FOR U.S. DEPARTMENT OF ENERGY WASTE MANAGEMENT FACILITIES}

\section{F.1 BACKGROUND}

Both the U.S. Department of Energy (DOE) and the U.S. Nuclear Regulatory Commission (NRC) require that the hazards and risks intrinsic to the operation of their facilities be analyzed and documented in safety analysis reports. These documents describe the effects of failed safety-related plant equipment and structures and of external hazards such as tormados, tidal waves, floods, extreme heat or cold, and aircraft impacts.

The accident scenarios in safety analyses evaluate the limiting effects that can result from natural phenomena, system failures, and operator errors, that is, the maximum hazard that could result from facility operation. In the DOE system, facilities are classified as producing a negligible, low (Category 3), moderate (Category 2), or high (Category 1) hazard with respect to the worst-case accident effects on other site employees, the public, and environment. External events, such as an aircraft crash into a facility, can initiate these worst-case accidents and must therefore be considered in the analysis. This appendix summarizes the aircraft impact initiator frequencies estimated for various Waste Management (WM) Programmatic Environmental Impact Statement (PEIS) (DOE 1995) facilities at different DOE sites.

Various authors have developed extensive aircraft operational data and compiled crash statistics. Many of these studies have been performed to support the design and siting of nuclear power plants. These estimates are used to estimate the risk of aircraft crashes at facilities in different locations.

Aircraft crash analyses have historically divided crash data into three groups: commercial, military, and general aviation. By far the most complete records of aircraft operational data and crash information are available for commercial carriers. The National Transportation Safety Board (NTSB) publishes detailed annual reports of the number of commercial flights; distances flown; numbers of takeoffs and landings for each airport; and types of aircraft in use, their capacities, loadings, numbers of passengers, and other data. Detailed reviews of all crashes and accidents are also available.

Less detailed information is available for general aviation operations. Larger airports tabulate operational information on private aircraft that is reported by the NTSB in its annual reports. General aviation crash data are obtained and recorded by the NTSB. These reports are not as detailed or as voluminous as those for commercial carriers, but each crash is investigated and the data are tabulated.

Military aircraft operations and crash data are generally not publicly available. Some information on hours flown and accidents for the various types of military aircraft has been 
published; however, use of this information in the present analysis is complicated by a lack of information about which data apply to the public at large. For this study, the frequency of military air crashes was assumed to be equal to the frequency of commercial air carriers for those DOE sites with significant military operations nearby. Although these data are incomplete, some general conclusions can be drawn.

\section{F.2 METHODOLOGY}

Safety assessments were performed for commercial nuclear power stations to estimate the risk from their operation and to ensure that these risks were reduced to a level acceptable to the public. As part of these assessments, the Atomic Energy Commission (AEC) examined the probabilities of aircraft impacts on power plants that could result in a release of radioactive material. In the 1960s, the AEC compiled data on aircraft crashes and found that an increased strike probability was observed within $8 \mathrm{~km}$ (5 mi) of airports, with an approximate $1 / r^{2}$ relationship, where $r$ is the distance from the airport. It was noted further that most crashes occurred within the $60^{\circ}$ arcs centered on the centerline of each end of airport runways. For general aviation aircraft, these arcs extend $8 \mathrm{~km}(5 \mathrm{mi})$ from the end of the runway; for commercial aircraft, they extend $16 \mathrm{~km}$ (10 mi). Beyond this distance, the probabilities of crashes were lower and essentially constant. A method for estimating this risk was developed by Wall (1974) and Eisenhut (1972, 1973) and implemented by the AEC. This method is still used by the NRC, with some modifications, and is formalized in NUREG-0800 (NRC 1981), which is used to review license applications, and in WASH-1400 (NRC 1975), the Reactor Safety Study.

The NUREG-0800 method determines the probability of an aircraft crash per square mile per aircraft movement. General aviation movement and crash data accumulated and involving approximately $3.2 \mathrm{E}+08$ movements and $4.0 \mathrm{E}+03$ crashes were reviewed. Air carrier (commercial) data were based on $8.0 \mathrm{E}+07$ movements, and military data were based on 9.4E+07 movements. No dates for the collection of these data are provided in the references of NUREG-0800. It was concluded that only fatal accidents were significant with respect to aircraft crashes into buildings. Wall (1974) and Eisenhut (1972, 1973) identified a strong correlation between accidents involving fatalities and those destroying the aircraft. In addition, it was assumed that an aircraft striking a building would generally involve fatalities and destruction of the airframe.

Probabilities were provided only for general aviation and military aircraft crashes within $8 \mathrm{~km}(5 \mathrm{mi})$ of the end of airfield runways and for air carriers (commercial aviation) within $16 \mathrm{~km}$ (10 $\mathrm{mi}$ ) of the end of the respective runway and within a $60^{\circ}$ arc at the extended centerline of the runway (Figure F.1). The method was originally a comparison of crashes per unit area with the effective target area. 


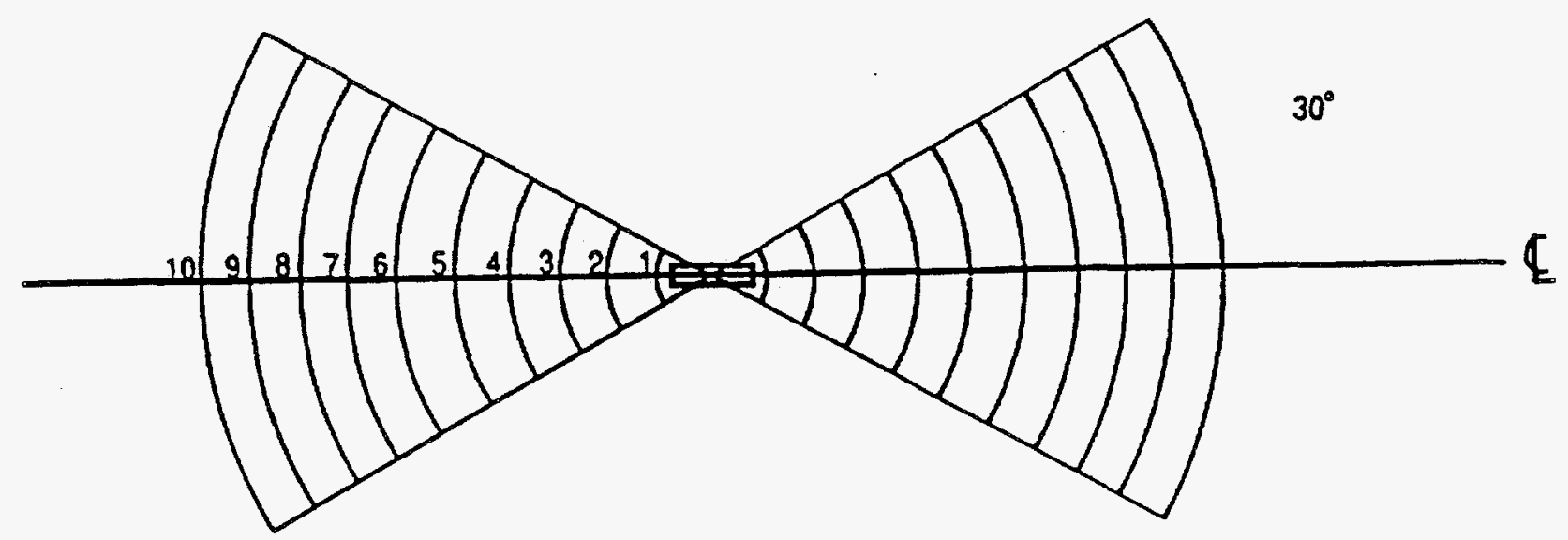

FIGURE F.1 Generic Representation of Takeoff and Landing Sectors

The crash probability equation is

$$
P_{A}=\Sigma_{j} N_{j} \times A_{j} \times f_{j},
$$

$=\quad$ Probability of an aircraft accident resulting in structural damage,

where

$N=$ number of airport runway operations affecting the target;

$A=$ target vulnerable area $\left(\mathrm{mi}^{2}\right)$;

$f=$ fatal crash probability per operation $\left(\mathrm{mi}^{2}\right)$; and

$j=$ aircraft type identifier: commercial, military, and general.

The NUREG-0800 crash probability equation was modified to consider proximity to designated federal airways:

$$
\begin{gathered}
P_{N R C}=P_{A}+P_{F A}, \\
\left.=\sum_{i=1}^{L} \sum_{j=1}^{M} \sum \mathrm{C}_{\mathrm{j}} \times \mathrm{N}_{\mathrm{ij}} \times \mathrm{A}_{j}\right]+\underset{k=i}{+} \sum_{\mathrm{j}=1}^{M} \sum \mathrm{C}_{\mathrm{FA}} \times \mathrm{N}_{\mathrm{FAkj}} \times \mathrm{A}_{j} / \mathrm{w}_{\mathrm{k}}, \\
=\text { total aircraft hazard probability, }
\end{gathered}
$$


where

$$
\begin{aligned}
P_{A}= & \begin{array}{l}
\text { probability per year of an aircraft crashing into a site near an } \\
\text { airport, }
\end{array} \\
P_{F A}= & \begin{array}{l}
\text { probability per year of an aircraft crashing into a site near a } \\
\text { federal airway, }
\end{array} \\
M= & \text { number of different types of aircraft using the airport, } \\
L= & \text { number of flight trajectories affecting the site, } \\
Q= & \text { number of airways affecting the site, } \\
C_{j}= & \text { probability per square mile of a crash per aircraft movement, } \\
N_{i j}= & \text { number of movements per year by the } j \text { th aircraft along the } i \text { th } \\
& \text { flight path, } \\
A_{j}= & \text { effective target area in square miles for the } j \text { th aircraft } \\
& \text { considering shadow area and skid area, } \\
w_{k}= & \text { width of the } k \text { th airway in miles (plus twice the distance from the } \\
& \text { airway edge to the site when the site is outside the airway). } \\
C_{F A}= & \text { in-flight crash rate per mile for aircraft on an airway, } \\
N_{F A k j}= & \text { number of flights per year of } j \text { th aircraft along the } k \text { th airway, } \\
i= & \text { aircraft path identifier, }
\end{aligned}
$$

NUREG-0800 uses a value of 4.0E-10 per mile for $C_{F A}$ for commercial aircraft on airways with fewer than 100 flights per day. For heavily traveled corridors (greater than 100 flights per day), a more detailed analysis is suggested to obtain a proper value for $C_{F A}$. Table F.1 summarizes the values of $C_{j}$ suggested in NUREG-0800. 


\section{TABLE F.1 Probabilities of a Fatal Crash}

\begin{tabular}{ccccc}
\hline $\begin{array}{c}\text { Distance } \\
\text { from } \\
\begin{array}{c}\text { End of } \\
\text { Runway } \\
(\text { mi) }\end{array}\end{array}$ & \multicolumn{5}{c}{ Probability $\left(\times 10^{8}\right) \begin{array}{c}\text { of a Fatal Crash per Square Mile per } \\
\text { Aircraft Movement }\end{array}$} \\
\cline { 2 - 5 } & $\begin{array}{c}\text { U.S. Air } \\
\text { Carrier }\end{array}$ & $\begin{array}{c}\text { General } \\
\text { Aviation }\end{array}$ & $\begin{array}{c}\text { U.S. Navy/ } \\
\text { U.S. Marine Corps }\end{array}$ & U.S. Air Force \\
\hline & & & & \\
$0-1$ & 16.7 & 84 & 8.3 & 5.7 \\
$1-2$ & 4.0 & 15 & 1.1 & 2.3 \\
$2-3$ & 0.96 & 6.2 & 0.33 & 1.1 \\
$3-4$ & 0.68 & 3.8 & 0.31 & 0.42 \\
$4-5$ & 0.27 & 1.2 & 0.20 & - \\
$5-6$ & 0 & - a & - & - \\
$6-7$ & 0 & - & - & - \\
$7-8$ & 0 & - & - & - \\
$8-9$ & 0.14 & - & - & - \\
$9-10$ & 0.12 & - & - & - \\
\hline
\end{tabular}

a A hyphen indicates data not available for this distance.

Source: Eisenhut (1973).

The NUREG-0800 method is applied in accordance with Title 10 of the Code of Federal Regulations (CFR), Part 100, which, in conjunction with other criteria, assures that a proposed reactor site will involve a low risk to the public. This requirement is met when the probability of aircraft accidents resulting in radiological consequences greater than the criteria in 10 CFR 100 is less than approximately $1.0 \mathrm{E}-07$ per year.

\section{F.2.1 CRASH PROBABILITY ESTIMATES}

In this section, a crash probability estimation method is developed specific to DOE waste management facilities utilizing the previous methods as guides and applying DOE site data obtained during the study. The method selected for DOE waste management facilities parallels that used by the NRC (NRC 1981) and is based on the methods of Wall (1974) and Eisenhut $(1972,1973)$.

The total probability of an aircraft crash into a DOE waste management facility is considered the sum of the probabilities for each category of aircraft examined:

$$
P_{\text {total }}=P_{c}+P_{m}+P_{g}
$$

where

$$
\begin{aligned}
& P_{c}=\text { commercial carrier probability per year, } \\
& P_{m}=\text { military probability per year, and } \\
& P_{g}=\text { general aviation probability per year. }
\end{aligned}
$$


The probability of an aircraft crash by aircraft category is estimated by examining two phases of aircraft flight: takeoffs/landings and en route crashes. Consistent with the NUREG-0800 methodology, takeoff and landing aircraft crashes are significant within $8 \mathrm{~km}(5 \mathrm{mi})$ of an airport for general aviation and within $16 \mathrm{~km}(10 \mathrm{mi})$ for commercial and military aviation.

The sites listed in Table F.2 have been identified as the principal DOE waste management sites. For each of these sites, world aeronautical charts (WACs) and the National Plan for Integrated Airport Systems (NPIAS) were examined to estimate the locations of the nearest commercial and general aviation airports. The WACs and NPIAS were reviewed to determine runway orientation with respect to DOE facilities.

Table F.3 summarizes data on each of the DOE facilities and nearby airports. The table provides the estimated distance to the airport and the number of airport runways that potentially result in increased overflights of the DOE facility. (The NUREG-0800 methodology recognizes an increased aircraft crash probability in a $60^{\circ}$ arc extending $30^{\circ}$ in each direction from the runway centerline.) The runway orientation and distance to the nearest facility are used to determine whether a DOE site has the potential for a significant increase in the probability of takeofflanding aircraft crashes. Table F.3 identifies the following five sites as having the potential for significant takeoff/landing crashes: Lawrence Livermore National Laboratory (LLNL) Site 300, Paducah Gaseous Diffusion Plant (PGDP),

TABLE F.2 Principal DOE Waste Management Sites

\begin{tabular}{lc}
\hline \multicolumn{1}{c}{ DOE Site } & Abbreviation \\
\hline Fernald Environmental Management Project & FEMP \\
Idaho National Engineering Laboratory & INEL \\
Hanford Site & Hanford \\
Kansas City Plant & KCP \\
Lawrence Livermore National Laboratory & LLNL \\
$\quad$ Main Site and Site 300) & LANL \\
Los Alamos National Laboratory & NTS \\
Nevada Test Site & ORR \\
Oak Ridge National Laboratory (Y-12, K-25) & PGDP \\
Paducah Gaseous Diffusion Plant & Pantex \\
Pantex Plant & PORTS \\
Portsmouth Gaseous Diffusion Plant Project & RFETS \\
Rocky Flats Environmental Technology Site & SNL-NM \\
Sandia National Laboratories (New Mexico) & SRS \\
Savannah River Site & WVDP \\
West Valley Demonstration Project & \\
\hline
\end{tabular}


TABLE F.3 Airports near DOE Sites and their Potentials to Increase Aircraft Accident Frequencies

\begin{tabular}{llrrr}
\hline \multicolumn{1}{c}{ DOE Site } & \multicolumn{1}{c}{ Airfield } & $\begin{array}{c}\text { Facility } \\
\text { Distance } \\
(\text { mi) }\end{array}$ & $\begin{array}{c}\text { Sectors } \\
\text { Affecting } \\
\text { DOE }\end{array}$ & $\begin{array}{c}\text { Airport } \\
\text { Accidents } \\
\text { Significant? }\end{array}$ \\
\hline FEMP & Hamilton & 10 & 0 & No \\
FEMP & Harrison & 5 & 0 & No \\
Hanford & Richland & 5 & 1 & No \\
Hanford & Pasco & 8 & 1 & No \\
INEL & Mud Lake & 12 & 0 & No \\
INEL & Midway & 10 & 1 & No \\
INEL & Arco & 15 & 0 & No \\
INEL & Howe & 13 & 0 & No \\
KCP & Richards-Gebaur & 8 & 1 & No \\
KCP & Lee's Summit & 12 & 0 & No \\
KCP & Downtown & 11 & 0 & No \\
KCP & Heart & 8 & 1 & No \\
LLNL & Livermore & 7 & 2 & No \\
LLNL Site 300 & Tracy & 4 & 1 & No \\
LANL & Los Alamos & 1 & 0 & No \\
NTS & Pahute Mesa & 12 & 0 & No \\
NTS & Desert Rock & 15 & 0 & No \\
ORR, Y-12, K-25 & None & & & No \\
Pantex & Amarillo International & 5 & 1 & Yes \\
Pantex & Skellytown & 9 & 0 & No \\
PGDP & Barkley & 3 & 1 & Yes \\
PORTS & Greater Portsmouth & 10 & 0 & No \\
PORTS & Pike County & 6 & 0 & No \\
RFETS & Boulder & 15 & 0 & No \\
RFETS & Jefferson County & 5 & 2 & Yes \\
RFETS & Tri-County & 13 & 0 & No \\
SNL-NM & Albuquerque International & 2 & 2 & Yes \\
SRS & Barnwell & 0 & No \\
\hline
\end{tabular}

a No waste management activities take place within the area of the Hanford Site that is within $16 \mathrm{~km}(10 \mathrm{mi})$ of the Pasco Airport and $8 \mathrm{~km}(5 \mathrm{mi})$ of the Richland Airport.

Pantex Plant (Pantex), Rocky Flats Environmental Technology Site (RFETS), and Sandia National Laboratories (New Mexico) (SNL-NM). Of these five sites, two have only general aviation service (LLNL Site 300 and RFETS). Airports near the PGDP site provide both commercial and general aviation service. Airports near the Pantex and SNL-NM sites have commercial, general aviation service, and military operations.

The four DOE sites listed in Table F.4 are located beneath federal airways. These four sites have the potential for increased en route aircraft crashes. The four affected DOE sites are Pantex, SRS, INEL, and Hanford. At INEL, the federal airway crosses the southwest corner of the site. No facilities are located in this portion of the INEL site. Table F.4 also provides estimated overflight frequencies for these sites. 
TABLE F.4 Estimated Annual Overflight Frequencies of DOE Sites

\begin{tabular}{|c|c|c|c|}
\hline DOE Site & Commercial & General & Basis of Estimate \\
\hline Hanford & 6,450 & 22,500 & $\begin{array}{l}15 \% \text { of Pasco } \\
15 \% \text { of Richland }\end{array}$ \\
\hline INEL & 1,500 & 2,900 & $20 \%$ of Pocatello \\
\hline Pantex & 3,800 & 15,300 & $15 \%$ of Amarillo \\
\hline SRS & 6,300 & 21,700 & $\begin{array}{l}20 \% \text { of Allendale } \\
10 \% \text { of Savannah } \\
10 \% \text { of Augusta }\end{array}$ \\
\hline
\end{tabular}

\section{F.2.1.1 Commercial Aviation}

For each site, the probability of a commercial aviation crash was estimated according to the following equation:

where

$$
P_{e}=P_{a}+P_{F A}
$$

$$
\begin{aligned}
P_{e}= & \begin{array}{l}
\text { probability of crash per square mile per year at a specified } \\
\text { DOE site, }
\end{array} \\
P_{a}= & \begin{array}{l}
\text { probability of crash per square mile per year from nearby } \\
\text { airfield operations, and }
\end{array} \\
P_{F A}= & \begin{array}{l}
\text { probability of crash per square mile per year from } \\
\text { operations on a federal airway. }
\end{array}
\end{aligned}
$$

Table F.5 gives the estimated values of $P_{a}$ for the two DOE sites with airports with commercial operations in their vicinities.

Four DOE sites are located under federal airways; however, the estimated overflight rate for commercial aircraft is fewer than 100 flights per day at each site. Assuming that airways are $6 \mathrm{~km}(4 \mathrm{mi})$ wide, an upper-bound estimate of the probability of a crash per square mile from federal airway activities is found using the following equation:

$$
P_{F A}=4.0 \times 10^{-10} / \mathrm{mi} / \text { flight } \times \mathrm{N} \text { flights } / \mathrm{yr} / 4-\mathrm{mi} \text { width }
$$

Table F.6 summarizes estimates of crash probabilities from commercial aviation federal airway flights. Only the four DOE sites listed in Table F.6 are considered to be affected by commercial aircraft operations. This is because the NUREG-0800 methodology states that accidents are not credible at DOE sites located at distances greater than $16 \mathrm{~km}$ $(10 \mathrm{mi})$ from an airport if the sites are not crossed by a federal airway. 
TABLE F.5 Estimated Annual Crash Probabilities at DOE Sites from Commercial Aviation Operations at Nearby Airports

\begin{tabular}{llcccccc}
\hline DOE Site & Airfield & $\begin{array}{c}\text { Facility } \\
\text { Distance } \\
(\mathrm{mi})\end{array}$ & Runways & $\begin{array}{c}\text { Sectors } \\
\text { Affecting } \\
\text { DOE }\end{array}$ & $\begin{array}{c}\text { Commercial } \\
\text { Operations/yr }\end{array}$ & $\begin{array}{c}\text { Crash Rate per } \\
\text { Movement } \\
\left(\mathrm{mi}^{2} / \mathrm{yr}\right)\end{array}$ & $\begin{array}{c}\text { Crash Rate } \\
\left(\mathrm{mi}^{2} / \mathrm{yr}\right)\end{array}$ \\
\hline Pantex & $\begin{array}{c}\text { Amarillo } \\
\text { International }\end{array}$ & 5 & 1 & 2 & 25,000 & $6.8 \mathrm{E}-10$ & $1.7 \mathrm{E}-05$ \\
SNL-NM & $\begin{array}{c}\text { Albuquerque } \\
\text { International }\end{array}$ & 2 & 2 & 4 & 161,000 & $1.0 \mathrm{E}-08$ & $1.6 \mathrm{E}-03$ \\
\hline
\end{tabular}

TABLE F.6 Estimated Annual Federal Airway Commercial Crash Probabilities

\begin{tabular}{lcc}
\hline DOE Site & $\begin{array}{c}\text { Number of } \\
\text { Overflights }\end{array}$ & $\begin{array}{c}\text { Federal Airway } \\
\text { Crash Probability } \\
\left(\mathrm{mi}^{2} / \mathrm{yr}\right)\end{array}$ \\
\hline Hanford & 6,450 & $6.5 \mathrm{E}-07$ \\
INEL & 1,500 & $1.5 \mathrm{E}-07$ \\
Pantex & 3,800 & $3.8 \mathrm{E}-07$ \\
SRS & 6,300 & $6.3 \mathrm{E}-07$ \\
\hline
\end{tabular}

\section{F.2.1.2 Military Aviation}

The method for estimating military aviation accidents is identical to that for commercial aircraft. Only two DOE sites, SNL-NM and Pantex, have nearby military airfields, training areas, or operations areas within $16 \mathrm{~km}$ (10 mi). Military aircraft do not routinely use the commercial airways adjacent to DOE facilities but may occasionally fly in their proximity. The local military crash information obtained during this study was not sufficient to develop local crash statistics. Previous studies (Wall 1974) indicate that when operating as an air carrier, military aircraft have accident rates (per mile flown) approximately the same as those of commercial air carriers. These accident rates, however, may significantly overestimate the risk from military aircraft at DOE waste management facilities. The estimated risk from commercial aircraft is primarily due to the relatively heavy commercial traffic on airways adjacent to some DOE facilities. No such heavy military air traffic exists close to DOE facilities. For this study, the military accident probability, $P_{m}$, is estimated to be equivalent to the commercial probability for sites with nearby military air operations. Because the number of military operations is believed to be significantly less than the commercial operations in the vicinities of DOE facilities, this is a conservative assumption; however, adequate data were not available to quantify the degree of conservatism. 


\section{F.2.1.3 General Aviation}

The probability of general aviation accidents is estimated in a manner similar to that of NUREG-0800 (NRC 1981). According to the NUREG-0800 method, the probability of an aircraft crash within $8 \mathrm{~km}(5 \mathrm{mi})$ of an airport, $P_{G}$, will consist of two factors - aircraft operations within and beyond distances $8 \mathrm{~km}(5 \mathrm{mi})$ from an airport - according to the following equation:

$$
P_{G}=P_{A}+P_{F A}
$$

Table F.7 summarizes the number of general aviation aircraft movements and crash frequencies for the five DOE sites with nearby general aviation airfields.

To estimate the probability of general aviation en route accidents resulting in a release from a DOE facility, a method similar to the take-off and landing method was used. A general aviation accident frequency of $1.0 \mathrm{E}-04 / \mathrm{mi}^{2} / \mathrm{yr}$ (Wall 1974) was used for all sites.

After the frequency of the aircraft impact has been established, the likelihood of a hazardous material release will depend on the probability of containment breach. Fires can enhance the possibility for release of material. All these considerations are facility- and waste-dependent and are accounted for in the event trees developed to define the accident sequences. Although this appendix is concerned only with the frequency of the initiating event (the aircraft crash against the facility), source background information is provided in the following paragraphs on the effects of a crash on a generic facility.

\section{F.2.2 Penetration}

The significant missile associated with a small aircraft accident is assumed to be the aircraft engine. This assumption is consistent with the analysis of Chelapati et al. (1972), who note that other parts of the aircraft, such as wings and fuselage, offer less resistance and are assumed to break up on impact. The frame and wings of general aviation aircraft do not penetrate minimal thicknesses of reinforced concrete, they have low densities relative to the engine, and they crumple on impact, exhausting their kinetic energy in structural deformation. Larger aircraft airframes may offer greater resistance to crushing under impact. Chelapati et al. (1972) developed a distribution frequency for small aircraft engine weights and effective diameters and perforation and penetration estimates. On the basis of their analysis, estimates of the probability of light aircraft penetrating a hardened structure can be developed. For purposes of this analysis, it is assumed that a Category 2 facility will have a "hardness" that is equivalent to a minimum wall thickness of $20.3 \mathrm{~cm}(8 \mathrm{in}$.) of reinforced concrete. A Category 1 facility is assumed to have a minimum wall thickness of $30.5 \mathrm{~cm}$ (12 in.) of reinforced concrete. Table F.8 summarizes the probability of penetrating Category 1 and 2 facilities. For outdoor storage facilities, the penetration probability is conservatively assumed to be 1.0 . 
TABLE F.7 Estimated Annual Crash Probabilities at DOE Sites from General Aviation Operations at Nearby Airports

\begin{tabular}{|c|c|c|c|c|c|c|c|}
\hline DOE Site & Airfield & $\begin{array}{c}\text { Facility } \\
\text { Distance } \\
\text { (mi) }\end{array}$ & Runways & $\begin{array}{l}\text { Sectors } \\
\text { Affecting } \\
\text { DOE }\end{array}$ & $\begin{array}{c}\text { General } \\
\text { Aviation } \\
\text { Operations/yr }\end{array}$ & $\begin{array}{l}\text { Crash Rate/ } \\
\text { Movement } \\
\left(\mathrm{mi}^{2} / \mathrm{yr}\right)\end{array}$ & $\begin{array}{c}\text { Crash } \\
\text { Rate } \\
\left(\mathrm{mi}^{2} / \mathrm{yr}\right)\end{array}$ \\
\hline LLNL Site 300 & Tracy & 4 & 1 & 2 & 63,000 & $9.5 \mathrm{E}-09$ & $6.0 \mathrm{E}-04$ \\
\hline Pantex & $\begin{array}{l}\text { Amarillo } \\
\text { International }\end{array}$ & 5 & 1 & 2 & 102,000 & $3.0 \mathrm{E}-08$ & $9.6 \mathrm{E}-04$ \\
\hline PGDP & Barkley & 3 & 1 & 2 & 62,000 & $1.6 \mathrm{E}-08$ & $9.6 \mathrm{E}-04$ \\
\hline RFETS & $\begin{array}{l}\text { Jefferson } \\
\text { County }\end{array}$ & 5 & 2 & 3 & 190,000 & 4.0E-09 & $7.6 \mathrm{E}-04$ \\
\hline SNL-NM & $\begin{array}{l}\text { Albuquerque } \\
\text { International }\end{array}$ & 2 & 2 & 4 & 225,000 & $3.8 \mathrm{E}-08$ & $8.4 \mathrm{E}-03$ \\
\hline
\end{tabular}

TABLE F.8 General Aviation

Building Penetration Probabilities

\begin{tabular}{ccc}
\hline $\begin{array}{c}\text { Accident } \\
\text { Type }\end{array}$ & $\begin{array}{c}\text { Category } 1 \\
\text { Facility }\end{array}$ & $\begin{array}{c}\text { Category 2 } \\
\text { Facility }\end{array}$ \\
\hline $\begin{array}{l}\text { Takeoff/ } \\
\text { landing }\end{array}$ & 0.01 & 0.17 \\
En route & 0.34 & 0.69 \\
\hline
\end{tabular}

\section{F.2.3 Fire}

The occurrence of a fire subsequent to crash can have a significant impact on accident consequences. A fire could be a major factor in the spread of any radioactive material in a facility hit by aircraft. Without a fire, the spread of radioactive material would be significantly reduced and probably limited to only the vicinity of impact. A review of 108 aircraft crashes in northern California indicated that 36 had subsequent fires. This provides a probability of fire, $P_{f}$, of $3.3 \mathrm{E}-01$, which is consistent with the approximate $30 \%$ post-crash fire rate identified by Wall (1974) for general aviation craft.

\section{F.2.4 Presence of Radioactive Material}

The probability that an aircraft crash penetrating a structure will damage an area that contains radioactive material depends on facility layout and operating characteristics. For example, a facility that stores radioactive material will likely have a 1.0 probability of having radioactive material present $\left(P_{m}\right)$. A facility that requires significant supporting equipment to process radioactive material may have a value of $P_{m}=1.0 \mathrm{E}-02$. In this analysis, it is conservatively estimated that radioactive material will always be present at the crash location when an aircraft penetrates a structure, $P_{m}=1.0$. 


\section{F.3 SUMMARY OF AIRCRAFT CRASH FREQUENCIES PER UNIT OF LAND SURFACE}

Table F.9 summarizes estimated aircraft crash frequencies for all DOE sites and aircraft types.

\section{F.4 AIRCRAFT CRASH FREQUENCY FOR WM PEIS FACILITIES}

The methodology presented in Section F.2 is used to calculate the annual aircraft crash frequency per unit of ground surface. To estimate the frequency of an aircraft impact at a facility, it is necessary to calculate the effective area of the facility in question. The aircraft impact frequency at a facility can be estimated by multiplying the crash frequency per unit area summarized in Table F.9 by the effective facility area.

For the purpose of the WM PEIS (DOE 1995), two types of airplane crash accidents are considered: those involving large commercial airplanes and those involving small or general aviation aircraft. Military aircraft accidents, relevant only for two of the DOE sites considered, have been lumped with general aviation accidents because many of the reported crashes involve helicopters or training flights.

TABLE F.9 Summary of Annual Aircraft Crash Frequencies for DOE Sites

\begin{tabular}{|c|c|c|c|c|c|}
\hline \multirow[b]{2}{*}{ DOE Site } & \multicolumn{2}{|c|}{$\begin{array}{l}\text { Commercial } \\
\text { Crash Frequencies } \\
\left(\text { crash } / \mathrm{yr}-\mathrm{mi}^{2}\right)\end{array}$} & \multirow{2}{*}{$\begin{array}{l}\text { Military } \\
\text { Crash } \\
\text { Frequencies }\end{array}$} & \multicolumn{2}{|c|}{$\begin{array}{l}\text { General Aviation } \\
\text { Crash Frequencies } \\
\left(\text { crash } / \mathbf{y r}-\mathbf{m i}^{2}\right)\end{array}$} \\
\hline & $\begin{array}{l}\text { Nearby } \\
\text { Airport }\end{array}$ & $\begin{array}{l}\text { Federal } \\
\text { Airways }\end{array}$ & & $\begin{array}{l}\text { Nearby } \\
\text { Airport }\end{array}$ & En Route \\
\hline FEMP & $\mathrm{NA}^{\mathrm{a}}$ & NA & NA & $\mathrm{NA}$ & $1.0 \mathrm{E}-04$ \\
\hline Hanford & $\mathrm{NA}$ & $6.5 \mathrm{E}-07$ & $\mathrm{NA}$ & $\mathrm{NA}$ & $1.0 \mathrm{E}-04$ \\
\hline INEL & $\mathrm{NA}$ & $1.5 \mathrm{E}-07$ & $\mathrm{NA}$ & $\mathrm{NA}$ & $1.0 \mathrm{E}-04$ \\
\hline $\mathrm{KCP}$ & $\mathrm{NA}$ & NA & $\mathrm{NA}$ & $\mathrm{NA}$ & $1.0 \mathrm{E}-04$ \\
\hline LANL & $\mathrm{NA}$ & $\mathrm{NA}$ & $\mathrm{NA}$ & $\mathrm{NA}$ & $1.0 \mathrm{E}-04$ \\
\hline LLNL & $\mathrm{NA}$ & $\mathrm{NA}$ & NA & $\mathrm{NA}$ & $1.0 \mathrm{E}-04$ \\
\hline LLNL Site 300 & $\mathrm{NA}$ & $\mathrm{NA}$ & NA & $6.0 \mathrm{E}-04$ & NA \\
\hline NTS & $\mathrm{NA}$ & NA & NA & NA & $1.0 \mathrm{E}-04$ \\
\hline ORR & NA & NA & NA & NA & $1.0 \mathrm{E}-04$ \\
\hline Pantex & $1.7 \mathrm{E}-05$ & $3.8 \mathrm{E}-07$ & $1.7 \mathrm{E}-05$ & $3.1 \mathrm{E}-04$ & NA \\
\hline PGDP & NA & $\mathrm{NA}$ & NA & $9.6 \mathrm{E}-04$ & NA \\
\hline PORTS & $\mathrm{NA}$ & $\mathrm{NA}$ & NA & NA & $1.0 \mathrm{E}-04$ \\
\hline RFETS & NA & $\mathrm{NA}$ & NA & $7.6 \mathrm{E}-04$ & NA \\
\hline SNL-NM & $1.6 \mathrm{E}-03$ & NA & $1.6 \mathrm{E}-03$ & $8.4 \mathrm{E}-03$ & $\mathrm{NA}$ \\
\hline SRS & NA & $6.3 E-07$ & NA & NA & $1.0 \mathrm{E}-04$ \\
\hline
\end{tabular}

a $\mathrm{NA}=$ not applicable. 
Table F.10 groups the air crash data presented in Table F.9 into large and small aircraft crashes. The annual frequency per square mile of a large aircraft crash (APLL), as shown in Table F.10, includes the contribution of nearby airports, and the contribution of the proximity to federal airways. The annual frequency for small aircraft crash (APLS) includes the en route general aviation crash frequency, the proximity of airports, and the contribution of military aircraft, but not the contribution from on-site aircraft, including helicopters. Two DOE sites not mentioned in Section F.2, Argonne National Laboratory-East (ANL-E) and the Fermi National Accelerator Laboratory (Fermi), are included in Table F.10 because they were considered in the hazardous waste storage analysis (90-day storage facility or staging area) in Section 8 of this report. Since the two sites are not listed among the DOE sites affected by proximity to airports or by federal airways, the contribution to aircraft risk is by general aviation en route crashes $\left(10^{-4} / \mathrm{yr}^{-\mathrm{mi}^{2}}\right)$.

\section{F.4.1 Facility Target Area}

The calculation of effective facility area also follows the methodology of NUREG-0800 (NRC 1981). The target area offered by a facility is usually estimated as an effective area that takes into consideration the facility plan (horizontal projection) area, a shadow area, and a skid area. Figure F.2 shows a representation of these three components of the effective area (Kot et al. 1982). For particular facilities, there will be additional considerations, like the possible shielding by adjacent buildings or hills. The effect of the wingspan of the aircraft is also considered.

TABLE F.10 Summary of Annual Aircraft Crash Frequency Per Square Mile Grouped into APLL and APLS Crashes

\begin{tabular}{|c|c|c|c|c|c|c|c|}
\hline \multirow[b]{2}{*}{ DOE Site } & \multicolumn{2}{|c|}{ Commercial Aircraft } & \multirow{2}{*}{$\begin{array}{l}\text { Military } \\
\text { Aviation }\end{array}$} & \multicolumn{2}{|c|}{ General Aviation } & \multirow[b]{2}{*}{ APLL } & \multirow[b]{2}{*}{ APLS } \\
\hline & Airport & Airways & & Airport & Airways & & \\
\hline ANL-E & NA & NA & NA & NA & $1.0 \mathrm{E}-04$ & NA & $1.0 \mathrm{E}-04$ \\
\hline FEMP & $\mathrm{NA}^{\mathrm{a}}$ & NA & NA & NA & $1.0 \mathrm{E}-04$ & NA & $1.0 \mathrm{E}-04$ \\
\hline Fermi & $\mathrm{NA}$ & NA & NA & NA & $1.0 \mathrm{E}-04$ & NA & $1.0 \mathrm{E}-04$ \\
\hline Hanford & NA & $6.5 \mathrm{E}-07$ & NA & NA & $1.0 \mathrm{E}-04$ & $6.5 \mathrm{E}-07$ & $1.0 \mathrm{E}-04$ \\
\hline INEL & NA & $1.5 \mathrm{E}-07$ & NA & NA & $1.0 \mathrm{E}-04$ & $1.5 \mathrm{E}-07$ & 1.0E-04 \\
\hline KCP & NA & NA & NA & NA & $1.0 E-04$ & NA & $1.0 \mathrm{E}-04$ \\
\hline LANL & NA & NA & NA & NA & NA & NA & $1.0 \mathrm{E}-04$ \\
\hline LLNL & NA & NA & NA & NA & $1.0 \mathrm{E}-04$ & NA & $1.0 \mathrm{E}-04$ \\
\hline NTS & NA & NA & NA & NA & $1.0 \mathrm{E}-04$ & NA & $1.0 \mathrm{E}-04$ \\
\hline ORR & NA & NA & NA & NA & $1.0 \mathrm{E}-04$ & NA & $1.0 \mathrm{E}-04$ \\
\hline Pantex & $1.7 E-05$ & $3.8 E-07$ & $1.7 \mathrm{E}-05$ & $3.1 \mathrm{E}-04$ & NA & $1.7 \mathrm{E}-05$ & $3.3 \mathrm{E}-04$ \\
\hline PGDP & NA & NA & NA & $9.6 \mathrm{E}-04$ & NA & NA & $9.6 \mathbf{E}-04$ \\
\hline PORTS & $\mathrm{NA}$ & NA & $\mathrm{NA}$ & NA & $1.0 \mathrm{E}-04$ & $\mathrm{NA}$ & $1.0 \mathrm{E}-04$ \\
\hline RFETS & NA & NA & NA & $7.6 \mathrm{E}-04$ & NA & NA & $7.6 \mathrm{E}-04$ \\
\hline SNL & $1.6 \mathrm{E}-03$ & NA & $1.6 \mathrm{E}-03$ & $8.4 E-03$ & $\mathrm{NA}$ & $1.6 \mathrm{E}-03$ & $1.0 \mathrm{E}-02$ \\
\hline SRS & NA & $6.3 \mathrm{E}-07$ & NA & NA & $1.0 \mathrm{E}-04$ & $6.3 \mathrm{E}-07$ & $1.0 \mathrm{E}-04$ \\
\hline
\end{tabular}

a $\mathrm{NA}=$ not applicable. 


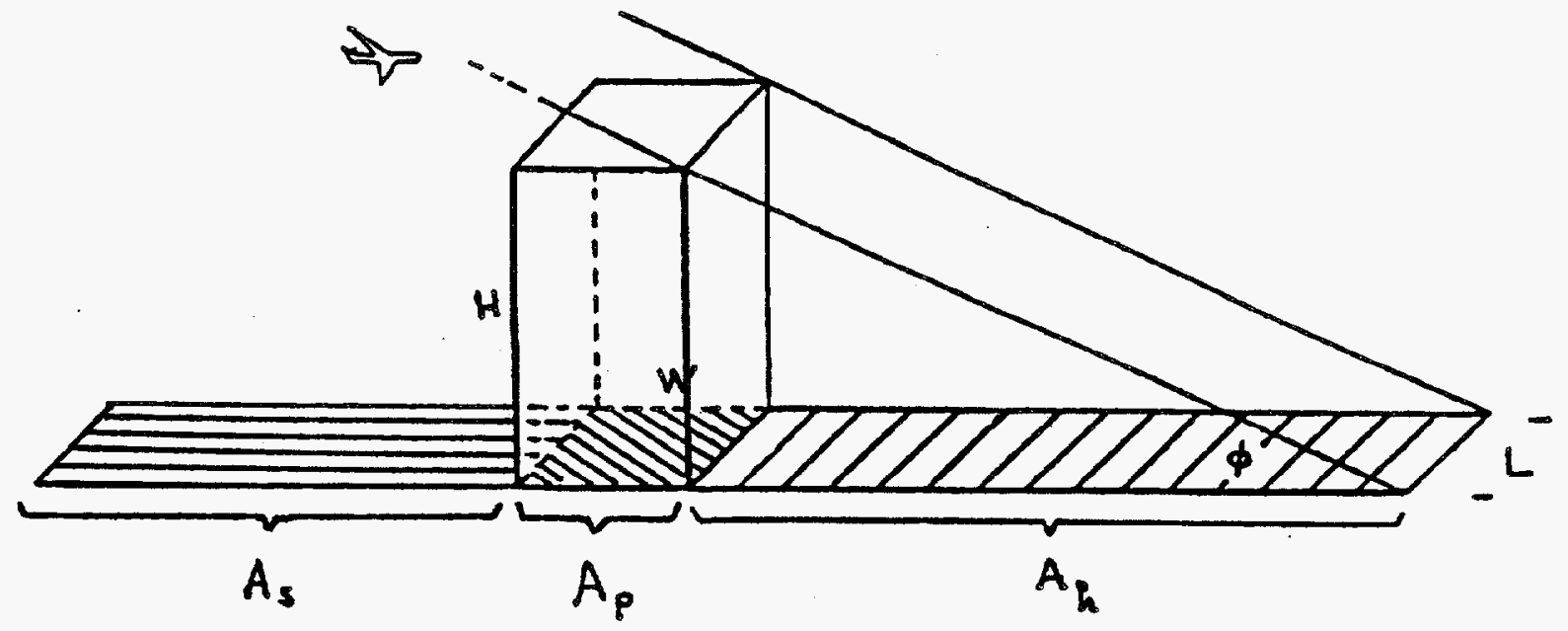

FIGURE F.2 Facility Target Area (Source: Adapted from Kot et al. 1982)

For a facility with dimensions $L$ (length), $W$ (width), and $H$ (height), the effective plan area can be estimated as

$$
A_{p}=(L+d) W
$$

where $d$ is the wingspan of the incoming aircraft. The average wingspan for small airplanes is approximately $12 \mathrm{~m}(39.4 \mathrm{ft})$, with $6 \mathrm{~m}(19.7 \mathrm{ft})$ between engines. For a large commercial aircraft, average wingspan is $50 \mathrm{~m}(164 \mathrm{ft})$, with $30 \mathrm{~m}(98 \mathrm{ft})$ between engines. The distance between engines is relevant for hardened structures, because the engines are more likely to penetrate them.

The skid area can be estimated as

$$
A_{s}=(L+d) s,
$$

where $s$ is the skid length, $100 \mathrm{~m}(328.1 \mathrm{ft})$ for small and $300 \mathrm{~m}(984.3 \mathrm{ft})$ for large airframes.

The shadow area can be estimated as

$$
A_{h}=(L+d) H / \tan \phi
$$

where $\phi$ is the glide angle, usually assumed to be $20^{\circ}$. 
The effective target area, $A_{\text {eff }}$, is the addition of the three components:

$$
A_{\text {eff }}=A_{p}+A_{s}+A_{h}
$$

Some reports have estimated the shadow area in terms of the longest facility dimension, rather than in terms of the length, that is,

$$
A_{h}=\left(\left(L^{2}+W^{2}\right)^{0.5}+d\right) H / \tan \phi
$$

For the facility dimensions used in the WM PEIS, there is no appreciable difference in the effective area between the two equations, and the initial equation for the shadow area is used. Table F.11 shows the effective facility areas for low-level waste (LLW), low-level mixed waste (LLMW), transuranic waste (TRUW), high-level waste (HLW), and hazardous waste (HW) facilities.

The dimensions of the LLW storage facility were based on WM PEIS information developed by INEL (Feizollahi and Shropshire 1992) for the generic facility size to be used for LLW storage. The incineration (or treatment) facilities for LLW, HLW and $H W$, although processing different throughput at different sites, have been assumed to be of a single size for the purpose of evaluating the effective area. The size of a medium WM PEIS incineration facility, as reported in Feizollahi and Shropshire (1992), has been used as the basis for the size. The dimensions reported have been increased and rounded up to account for the additional areas (e.g., waste staging area, stack exhaust system, electrical substation) attached to the main building. The same facility sizes used in LLW facilities were used for LLMW and TRUW facilities.

The size of the generic storage facility for hazardous waste, which is in fact a staging area, has been assumed to be one-quarter that of the generic LLW storage facility. The height of the facility has been assumed to be a more realistic $5 \mathrm{~m}(16 \mathrm{ft})$. Even with this reduction, the size selected conservatively envelops the Hazardous Waste Storage Facility at INEL, for example. For HLW, current storage takes place in underground tanks, so the effective area does not include skid- or shadow-area considerations. There will also be areas between the tanks where a crash would not be as harmful as a direct hit. The effective shape and dimensions of a tank farm have been assumed to be a square with a side of $100 \mathrm{~m}(328 \mathrm{ft})$.

\section{F.4.2 Frequency of Aircraft Crashes Against Facilities at DOE Sites}

Combining the estimated annual frequency of a crash per square mile with the calculated effective areas for the different facilities, the annual frequency of the initiating events for crashes of large and small aircraft (APLL and APLS, respectively) at different 
TABLE F.11 Effective Area Estimates for LLW, LLMW, TRUW, HLW, and HW Facilities

\begin{tabular}{|c|c|c|c|c|c|c|c|c|c|c|c|c|c|}
\hline Facility & $\begin{array}{l}\text { Size of } \\
\text { Aircraft }\end{array}$ & $\begin{array}{l}\text { Length } \\
\text { (m) }\end{array}$ & $\begin{array}{l}\text { Width } \\
(\mathrm{m})\end{array}$ & $\begin{array}{l}\text { Height } \\
\text { (m) }\end{array}$ & $\begin{array}{l}\text { Skid } \\
(\mathrm{m})\end{array}$ & $\begin{array}{l}\text { Wingspan } \\
\text { (m) }\end{array}$ & $\begin{array}{l}\text { Plan } \\
\text { Area } \\
\left(m^{2}\right)\end{array}$ & $\begin{array}{l}\text { Skid } \\
\text { Area } \\
\left(\mathrm{m}^{2}\right)\end{array}$ & $\begin{array}{l}\text { Shadow } \\
\text { Area } \\
\left(\mathrm{m}^{2}\right)\end{array}$ & $\begin{array}{l}\text { Total } \\
\text { Area } \\
\left(\mathrm{m}^{2}\right)\end{array}$ & $\begin{array}{l}\text { Total } \\
\text { Area } \\
\left(\mathrm{mi}^{2}\right)\end{array}$ & SAIC Value $\left(\mathrm{mi}^{2}\right)$ & $\begin{array}{c}\text { Effective } \\
\text { Area } \\
\left(\mathrm{mi}^{2}\right)\end{array}$ \\
\hline \multicolumn{14}{|l|}{$\begin{array}{l}\text { LLW, LLMW, } \\
\text { TRUW }\end{array}$} \\
\hline Storage & APLL & 100 & 50 & $\mathbf{3}$ & 300 & 50 & 7,500 & 45,000 & 1,236 & 53,736 & $2.1 E-02$ & $6.8 \mathrm{E}-03 / 1.9 \mathrm{E}-02$ & $2.1 \mathrm{E}-02$ \\
\hline Storage & APLS & 100 & 50 & 3 & 100 & 12 & 5,600 & 11,200 & 923 & 17,723 & $6.9 \mathrm{E}-03$ & $6.8 \mathrm{E}-03 / 5.6 \mathrm{E}-03$ & $7.0 \mathrm{E}-03$ \\
\hline Incinerator & APLL & 100 & 50 & 10 & 300 & 30 & 6,500 & 39,000 & 3,572 & 49,072 & $1.9 \mathrm{E}-02$ & $6.8 \mathrm{E}-03 / 1.7 \mathrm{E}-02$ & $1.8 \mathrm{E}-02$ \\
\hline Incinerator & APLS & 100 & 50 & 10 & 100 & 3 & 5,300 & 10,600 & 2,912 & 18,812 & $7.4 \mathrm{E}-03$ & $6.8 \mathrm{E}-03 / 5.3 \mathrm{E}-03$ & $7.0 \mathrm{E}-03$ \\
\hline \multicolumn{14}{|l|}{ HLW } \\
\hline DST $^{\mathrm{a}}$ & APLL & 100 & 100 & $N A^{b}$ & NA & NA & 10,000 & 0 & 0 & 10,000 & $3.9 \mathrm{E}-03$ & NA & $4.0 \mathrm{E}-03$ \\
\hline DST & APLS & 100 & 100 & NA & NA & NA & 10,000 & 0 & 0 & 10,000 & $3.9 \mathrm{E}-03$ & NA & $4.0 \mathrm{E}-03$ \\
\hline Other & APLL & 100 & 50 & 10 & 300 & 30 & 6,500 & 39,000 & 3,572 & 49,072 & $1.9 \mathrm{E}-02$ & $1.8 \mathrm{E}-02$ & $1.8 \mathrm{E}-02$ \\
\hline Other & APLS & 100 & 50 & 10 & 100 & 6 & 5,300 & 10,600 & 2,912 & 18,812 & $7.4 \mathrm{E}-03$ & $6.5 E-03$ & $7.0 \mathrm{E}-03$ \\
\hline \multicolumn{14}{|l|}{ HW } \\
\hline Storage & APLL & 50 & 25 & 5 & 300 & 50 & 2,500 & 30,000 & 1,374 & 33,874 & $1.3 \mathrm{E}-02$ & NA & $1.3 \mathrm{E}-02$ \\
\hline Storage & APLS & 50 & 25 & $\mathbf{5}$ & 100 & 12 & 1,550 & 6,200 & 852 & 8,602 & $3.4 \mathrm{E}-03$ & NA & $3.0 \mathrm{E}-03$ \\
\hline Treatment & APLL & 100 & 50 & 10 & 300 & 30 & 6,500 & 39,000 & 3,572 & 49,072 & $1.9 \mathrm{E}-02$ & NA & $1.8 \mathrm{E}-02$ \\
\hline Treatment & APLS & 100 & 50 & 10 & 100 & 6 & 5,300 & 10,600 & 2,912 & 18,812 & $7.4 \mathrm{E}-03$ & NA & $7.0 \mathrm{E}-03$ \\
\hline
\end{tabular}

a Abbreviation: $\mathrm{DST}=$ double-shell tank.

b $\mathrm{NA}=$ not applicable 
facilities can be estimated. The following tables list the frequencies of these two initiators by waste type, function, and DOE site. Only the sites considered for each waste and function have an associated initiating event frequency.

Table F.12 lists the frequencies for LLW storage at the 11 DOE sites considered in the WM PEIS alternative 9. The 11 sites cover the 11 major storage sites and, because the size of the facility is generic, storage facilities under other alternatives are also covered. These storage facilities were originally considered in screening accidents but were not analyzed for the PEIS. Table F.13 provides the annual frequencies for APLL and APLS at the LLW incineration facilities at the relevant sites.

Table F.14 shows the initiating event frequencies for HLW facilities at the two sites for which aircraft crashes were originally considered in screening accidents but were not analyzed (Hanford and SRS). Tables F.15 and F.16 provide the annual frequencies for hazardous waste storage and treatment facilities, respectively. The storage sites cover the 11 major locations (all alternatives covered). For treatment facilities, sites under Alternatives 2 and 3 are distinguished in the table. Tables F.17 and F.18 list the annual frequency of aircraft impacts on LLMW storage and treatment facilities at the relevant DOE sites; Tables F.19 and F.20 list similar information for TRUW facilities. As for LLW, the storage facilities for LLMW and TRUW were originally considered in screening accidents but were not analyzed for the PEIS.

TABLE F.12 Airplane Impacts Initiating Event Frequency: LLW Storage

\begin{tabular}{|c|c|c|c|c|c|c|}
\hline \multirow[b]{2}{*}{$\begin{array}{l}\text { DOE } \\
\text { Site }\end{array}$} & \multicolumn{3}{|c|}{ APLL } & \multicolumn{3}{|c|}{ APLS } \\
\hline & $\begin{array}{c}\text { Crash } \\
\text { Frequency } \\
\left(\text { crash } / y r-\mathrm{mi}^{2}\right)\end{array}$ & $\begin{array}{l}\text { Area } \\
\left(\mathbf{m i}^{2}\right)\end{array}$ & $\begin{array}{l}\text { Initiating } \\
\text { Event } \\
\text { Frequency } \\
\left(\mathrm{yx}^{-1}\right)\end{array}$ & $\begin{array}{c}\text { Crash } \\
\text { Frequency } \\
\left(\text { crash/yr-mi }{ }^{2}\right)\end{array}$ & $\begin{array}{l}\text { Area } \\
\left(\mathbf{m i}^{2}\right)\end{array}$ & $\begin{array}{c}\text { Initiating } \\
\text { Event } \\
\text { Frequency } \\
\left(\mathrm{yr}^{-1}\right)\end{array}$ \\
\hline ANL-E & NA & NA & NA & $1.0 \mathrm{E}-04$ & NA & NA \\
\hline FEMP & $\mathrm{NA}^{\mathrm{a}}$ & $2.1 \mathrm{E}-02$ & $\mathrm{NA}$ & $1.0 \mathrm{E}-04$ & $7.0 \mathrm{E}-03$ & 7.E-07 \\
\hline Fermi & NA & NA & $\mathrm{NA}$ & $1.0 \mathrm{E}-04$ & NA & NA \\
\hline Hanford & $6.5 \mathrm{E}-07$ & $2.1 \mathrm{E}-02$ & $1.4 E-08$ & $1.0 \bar{E}-04$ & $7.0 \mathrm{E}-03$ & $7.0 \mathrm{E}-07$ \\
\hline INEL & $1.5 \mathrm{E}-07$ & $2.1 E-02$ & $3.2 \mathrm{E}-09$ & 1.0E-04 & $7.0 \mathrm{E}-03$ & 7.E-07 \\
\hline $\mathrm{KCP}$ & NA & NA & NA & $1.0 \mathrm{E}-04$ & NA & NA \\
\hline LANL & $\mathrm{NA}$ & 2.1E-02 & NA & $1.0 \mathrm{E}-04$ & $7.0 \mathrm{E}-03$ & 7.E-07 \\
\hline LLNL & NA & $2.1 \mathrm{E}-02$ & NA & $1.0 \mathrm{E}-04$ & $7.0 E-03$ & 7.E-07 \\
\hline NTS & $\mathrm{NA}$ & NA & $\mathrm{NA}$ & $1.0 \mathrm{E}-04$ & NA & NA \\
\hline ORR & NA & 2.1E-02 & NA & $1.0 \mathrm{E}-04$ & $7.0 \mathrm{E}-03$ & $7.0 \mathrm{E}-07$ \\
\hline Pantex & $1.7 \mathrm{E}-05$ & $2.1 \mathrm{E}-02$ & 3.7E-07 & $3.3 \mathrm{E}-04$ & $7.0 \mathrm{E}-03$ & $2.3 \mathrm{E}-06$ \\
\hline PGDP & NA & $2.1 \mathrm{E}-02$ & NA & $9.6 \mathrm{E}-04$ & $7.0 \mathrm{E}-03$ & $6.7 \mathrm{E}-06$ \\
\hline PORTS & NA & $2.1 \bar{E}-02$ & NA & $1.0 \mathbf{E}-04$ & $7.0 \mathrm{E}-03$ & $7.0 \mathrm{E}-07$ \\
\hline RFETS & NA & $2.1 \mathrm{E}-02$ & NA & $7.6 \mathrm{E}-04$ & $7.0 \mathrm{E}-03$ & 5.3E-06 \\
\hline SNL-NM & $1.6 \mathrm{E}-03$ & NA & $\mathrm{NA}$ & $1.0 E-02$ & NA & NA \\
\hline SRS & $6.3 \mathrm{E}-07$ & $2.1 \mathrm{E}-02$ & $1.3 \mathrm{E}-08$ & $1.0 \mathrm{E}-04$ & $7.0 \mathrm{E}-03$ & $7.0 \mathrm{E}-07$ \\
\hline
\end{tabular}

a $\mathrm{NA}=$ not applicable. 
TABLE F.13 Airplane Impacts Initiating Event Frequency: LLW Incineration Facilities

\begin{tabular}{|c|c|c|c|c|c|c|}
\hline \multirow[b]{2}{*}{ DOE Site } & \multicolumn{3}{|c|}{ APLL } & \multicolumn{3}{|c|}{ APLS } \\
\hline & $\begin{array}{c}\text { Crash } \\
\text { Frequency } \\
\left(\text { (crash/yr-mi }{ }^{2}\right)\end{array}$ & $\begin{array}{l}\text { Area } \\
\left(\mathbf{m i}^{2}\right)\end{array}$ & $\begin{array}{l}\text { Initiating } \\
\text { Event } \\
\text { Frequency } \\
\left(\mathrm{yr}^{-1}\right)\end{array}$ & $\begin{array}{c}\text { Crash } \\
\text { Frequency } \\
\text { (crash/yr-mi }{ }^{2} \text { ) }\end{array}$ & $\begin{array}{l}\text { Area } \\
\left(\mathrm{mi}^{2}\right)\end{array}$ & $\begin{array}{c}\text { Initiating } \\
\text { Event } \\
\text { Frequency } \\
\left(\mathbf{y r}^{-1}\right)\end{array}$ \\
\hline ANL-E & NA & NA & NA & $1.0 \mathrm{E}-04$ & NA & NA \\
\hline FEMP & NA & $1.8 \mathrm{E}-02$ & NA & $1.0 \mathrm{E}-04$ & $7.0 \mathrm{E}-03$ & $7.0 \mathrm{E}-07$ \\
\hline Fermi & NA & NA & NA & $1.0 \mathrm{E}-04$ & NA & NA \\
\hline Hanford & $6.5 \mathrm{E}-07$ & $1.8 \mathrm{E}-02$ & $1.2 \mathrm{E}-08$ & $1.0 \mathrm{E}-04$ & $7.0 \mathrm{E}-03$ & $7.0 \mathrm{E}-07$ \\
\hline INEL & $1.5 \mathrm{E}-07$ & $1.8 \mathrm{E}-02$ & 2.7E-09 & $1.0 \mathrm{E}-04$ & $7.0 \mathrm{E}-03$ & $7.0 \mathrm{E}-07$ \\
\hline $\mathrm{KCP}$ & NA & NA & NA & $1.0 \mathrm{E}-04$ & NA & NA \\
\hline LANL & NA & $1.8 \mathrm{E}-02$ & NA & $1.0 \mathrm{E}-04$ & $7.0 \mathrm{E}-03$ & $7.0 \mathrm{E}-07$ \\
\hline LLNL & $\mathrm{NA}$ & $1.8 \mathrm{E}-02$ & NA & $1.0 \mathrm{E}-04$ & $7.0 \mathrm{E}-03$ & $7.0 \mathrm{E}-07$ \\
\hline NTS & $\mathrm{NA}$ & NA & $\mathrm{NA}$ & $1.0 \mathrm{E}-04$ & NA & NA \\
\hline ORR & $\mathrm{NA}$ & $1.8 \mathrm{E}-02$ & NA & $1.0 \mathrm{E}-04$ & $7.0 \mathrm{E}-03$ & $7.0 \mathrm{E}-07$ \\
\hline Pantex & $1.7 \mathrm{E}-05$ & $1.8 \mathrm{E}-02$ & 3.1E-07 & $3.3 \mathrm{E}-04$ & $7.0 \mathrm{E}-03$ & $2.3 \mathrm{E}-06$ \\
\hline PGDP & NA & $1.8 \mathrm{E}-02$ & NA & $9.6 \mathrm{E}-04$ & $7.0 \mathrm{E}-03$ & $6.7 \mathrm{E}-06$ \\
\hline PORTS & NA & $1.8 \mathrm{E}-02$ & NA & $1.0 \mathrm{E}-04$ & $7.0 \mathrm{E}-03$ & $7.0 \mathrm{E}-07$ \\
\hline RFETS & NA & $1.8 \mathrm{E}-02$ & NA & $7.6 \mathrm{E}-04$ & $7.0 \mathrm{E}-03$ & $5.3 \mathrm{E}-06$ \\
\hline SNL-NM & $1.6 \mathrm{E}-03$ & NA & NA & $1.0 \mathrm{E}-02$ & NA & NA \\
\hline SRS & 6.3E-07 & $1.8 \mathrm{E}-02$ & $1.1 \mathrm{E}-08$ & $1.0 \mathrm{E}-04$ & $7.0 \mathrm{E}-03$ & $7.0 \mathrm{E}-07$ \\
\hline
\end{tabular}

a $\mathrm{NA}=$ not applicable.

TABLE F.14 Airplane Impacts Initiating Event Frequency: HLW Facilities

\begin{tabular}{|c|c|c|c|c|c|c|}
\hline \multirow[b]{2}{*}{ Facility } & \multicolumn{3}{|c|}{ APLL } & \multicolumn{3}{|c|}{ APLS } \\
\hline & $\begin{array}{c}\text { Crash } \\
\text { Erequency } \\
\left(\text { crash }-\mathrm{mi}^{2}\right)\end{array}$ & $\begin{array}{l}\text { Area } \\
\left(\mathrm{mi}^{2}\right)\end{array}$ & $\begin{array}{l}\text { Initiating } \\
\text { Event } \\
\text { Frequency } \\
\left(\mathrm{yr}^{-1}\right)\end{array}$ & $\begin{array}{c}\text { Crash } \\
\text { Frequency } \\
\left(\text { crash } / \mathrm{yr}-\mathrm{mi}^{2}\right)\end{array}$ & $\begin{array}{l}\text { Area } \\
\left(\mathrm{mi}^{2}\right)\end{array}$ & $\begin{array}{l}\text { Initiating } \\
\text { Event } \\
\text { Frequency } \\
\left(\mathrm{yr}^{-1}\right)\end{array}$ \\
\hline \multicolumn{7}{|l|}{ Hanford } \\
\hline $\begin{array}{l}\text { DST } \\
\text { Pretreatment } \\
\text { Treatment } \\
\text { Glass storage }\end{array}$ & $\begin{array}{l}6.5 \mathrm{E}-07 \\
6.5 \mathrm{E}-07 \\
6.5 \mathrm{E}-07 \\
6.5 \mathrm{E}-07\end{array}$ & $\begin{array}{l}4.0 \mathrm{E}-03 \\
1.8 \mathrm{E}-02 \\
1.8 \mathrm{E}-02 \\
1.8 \mathrm{E}-02\end{array}$ & $\begin{array}{l}2.6 \mathrm{E}-09 \\
1.2 \mathrm{E}-08 \\
1.2 \mathrm{E}-08 \\
1.2 \mathrm{E}-08\end{array}$ & $\begin{array}{l}1.0 \mathrm{E}-04 \\
1.0 \mathrm{E}-04 \\
1.0 \mathrm{E}-04 \\
1.0 \mathrm{E}-04\end{array}$ & $\begin{array}{l}4.0 \mathrm{E}-03 \\
7.0 \mathrm{E}-03 \\
7.0 \mathrm{E}-03 \\
7.0 \mathrm{E}-03\end{array}$ & $\begin{array}{l}4.0 \mathrm{E}-07 \\
7.0 \mathrm{E}-07 \\
7.0 \mathrm{E}-07 \\
7.0 \mathrm{E}-07\end{array}$ \\
\hline \multicolumn{7}{|l|}{ SRS } \\
\hline $\begin{array}{l}\text { DST } \\
\text { Pretreatment } \\
\text { Treatment } \\
\text { Glass storage }\end{array}$ & $\begin{array}{l}6.3 \mathrm{E}-07 \\
6.3 \mathrm{E}-07 \\
6.3 \mathrm{E}-07 \\
6.3 \mathrm{E}-07\end{array}$ & $\begin{array}{l}1.8 \mathrm{E}-02 \\
1.8 \mathrm{E}-02 \\
1.8 \mathrm{E}-02 \\
1.8 \mathrm{E}-02\end{array}$ & $\begin{array}{l}2.5 \mathrm{E}-09 \\
1.1 \mathrm{E}-08 \\
1.1 \mathrm{E}-08 \\
1.1 \mathrm{E}-08\end{array}$ & $\begin{array}{l}1.0 \mathrm{E}-04 \\
1.0 \mathrm{E}-04 \\
1.0 \mathrm{E}-04 \\
1.0 \mathrm{E}-04\end{array}$ & $\begin{array}{l}4.0 \mathrm{E}-03 \\
7.0 \mathrm{E}-03 \\
7.0 \mathrm{E}-03 \\
7.0 \mathrm{E}-03\end{array}$ & $\begin{array}{l}4.0 \mathrm{E}-07 \\
7.0 \mathrm{E}-07 \\
7.0 \mathrm{E}-07 \\
7.0 \mathrm{E}-07\end{array}$ \\
\hline
\end{tabular}


TABLE F.15 Airplane Impacts Initiating Event Frequency: HW Storage Facilities

\begin{tabular}{|c|c|c|c|c|c|c|}
\hline \multirow[b]{2}{*}{$\begin{array}{l}\text { DOE } \\
\text { Site }\end{array}$} & \multicolumn{3}{|c|}{ APLL } & \multicolumn{3}{|c|}{ APLS } \\
\hline & $\begin{array}{c}\text { Crash } \\
\text { Frequency } \\
\left(\text { crash/yr- } \mathbf{m i}^{2}\right)\end{array}$ & $\begin{array}{l}\text { Area } \\
\left(\mathrm{mi}^{2}\right)\end{array}$ & $\begin{array}{l}\text { Initiating } \\
\text { Event } \\
\text { Frequency } \\
\left(\mathrm{yr}^{-1}\right)\end{array}$ & $\begin{array}{c}\text { Crash } \\
\text { Frequency } \\
\left(\text { crash } / \mathrm{yr}-\mathrm{mi}^{2}\right)\end{array}$ & $\begin{array}{l}\text { Area } \\
\left(\mathrm{mi}^{2}\right)\end{array}$ & $\begin{array}{l}\text { Initiating } \\
\text { Event } \\
\text { Frequency } \\
\left(\mathrm{yr}^{-1}\right)\end{array}$ \\
\hline ANL-E & NA & $1.3 \mathrm{E}-02$ & NA & $1.0 \mathrm{E}-04$ & $3.0 \mathrm{E}-03$ & $3.0 \mathrm{E}-07$ \\
\hline FEMP & $\mathrm{NA}^{\mathrm{a}}$ & NA & $\mathrm{NA}$ & $1.0 \mathrm{E}-04$ & NA & NA \\
\hline Fermi & NA & $1.3 \mathrm{E}-02$ & NA & $1.0 \mathrm{E}-04$ & $3.0 \mathrm{E}-03$ & $3.0 \mathrm{E}-07$ \\
\hline Hanford & $6.5 \mathrm{E}-07$ & $1.3 \mathrm{E}-02$ & $8.5 \mathrm{E}-08$ & $1.0 \mathrm{E}-04$ & $3.0 \mathrm{E}-03$ & $3.0 \mathrm{E}-07$ \\
\hline INEL & $1.5 \mathrm{E}-07$ & $1.3 \mathrm{E}-02$ & $2.0 \mathrm{E}-09$ & 1.0E-04 & $3.0 \mathrm{E}-03$ & $3.0 \mathrm{E}-07$ \\
\hline $\mathrm{KCP}$ & NA & 1.3E-02 & NA & $1.0 \mathrm{E}-04$ & $3.0 \mathrm{E}-03$ & $3.0 \mathrm{E}-07$ \\
\hline LANL & $\mathrm{NA}$ & $1.3 \mathrm{E}-02$ & NA & $1.0 \mathrm{E}-04$ & $3.0 \mathrm{E}-03$ & $3.0 \mathrm{E}-07$ \\
\hline LLNL & NA & $1.3 \mathrm{E}-02$ & NA & $1.0 \mathrm{E}-04$ & $3.0 \mathrm{E}-03$ & $3.0 \mathrm{E}-07$ \\
\hline NTS & NA & NA & NA & $1.0 \mathrm{E}-04$ & NA & NA \\
\hline ORR & NA & $1.3 \mathrm{E}-02$ & NA & $1.0 \mathrm{E}-04$ & $3.0 \mathrm{E}-03$ & $3.0 \mathrm{E}-07$ \\
\hline Pantex & $1.7 \mathrm{E}-05$ & 1.3E-02 & $2.3 \mathrm{E}-07$ & 3.3E-04 & $3.0 \mathrm{E}-03$ & $9.8 \mathrm{E}-07$ \\
\hline PGDP & NA & NA & NA & $9.6 \mathrm{E}-04$ & NA & NA \\
\hline PORTS & NA & NA & NA & $1.0 \mathrm{E}-04$ & NA & NA \\
\hline RFETS & NA & NA & NA & $7.6 \mathrm{E}-04$ & NA & NA \\
\hline SNL-NM & $1.6 \mathrm{E}-03$ & $1.3 E-02$ & $2.1 E-05$ & $1.0 \mathrm{E}-02$ & $3.0 \mathbf{E}-03$ & $3.0 \mathrm{E}-05$ \\
\hline SRS & $6.3 E-07$ & 1.3E-02 & $8.2 \mathrm{E}-09$ & $1.0 \mathrm{E}-04$ & $3.0 \mathbf{E}-03$ & $3.0 \mathrm{E}-07$ \\
\hline
\end{tabular}

a $\mathrm{NA}=$ not applicable.

TABLE F.16 Airplane Impacts Initiating Event Frequency: HW Treatment Facilities

\begin{tabular}{|c|c|c|c|c|c|c|}
\hline \multirow[b]{2}{*}{$\begin{array}{l}\text { DOE } \\
\text { Site }\end{array}$} & \multicolumn{3}{|c|}{ APLL } & \multicolumn{3}{|c|}{ APLS } \\
\hline & $\begin{array}{c}\text { Crash } \\
\text { Frequency } \\
\left(\text { crash/yr-mi }{ }^{2}\right)\end{array}$ & $\begin{array}{l}\text { Area } \\
\left(\mathrm{mi}^{2}\right)\end{array}$ & $\begin{array}{l}\text { Initiating } \\
\text { Event } \\
\text { Frequency } \\
\left(\mathrm{yr}^{-1}\right)\end{array}$ & $\begin{array}{c}\text { Crash } \\
\text { Frequency } \\
\left(\text { crash/yr-mi }{ }^{2}\right)\end{array}$ & $\begin{array}{l}\text { Area } \\
\left(\mathrm{mi}^{2}\right)\end{array}$ & $\begin{array}{l}\text { Initiating } \\
\text { Event } \\
\text { Frequency } \\
\quad\left(\mathrm{yr}^{-1}\right)\end{array}$ \\
\hline \multicolumn{7}{|c|}{ Alternative 2} \\
\hline $\begin{array}{l}\text { Hanford } \\
\text { INEL } \\
\text { LANL } \\
\text { ORR } \\
\text { SRS }\end{array}$ & $\begin{array}{l}6.5 \mathrm{E}-07 \\
1.5 \mathrm{E}-07 \\
\mathrm{NA} \\
\mathrm{NA} \\
6.3 \mathrm{E}-07\end{array}$ & $\begin{array}{l}1.8 \mathrm{E}-02 \\
1.8 \mathrm{E}-02 \\
1.8 \mathrm{E}-02 \\
1.8 \mathrm{E}-02 \\
1.8 \mathrm{E}-02\end{array}$ & $\begin{array}{c}1.2 \mathrm{E}-08 \\
2.7 \mathrm{E}-09 \\
\mathrm{NA} \\
\mathrm{NA} \\
1.1 \mathrm{E}-09\end{array}$ & $\begin{array}{l}1.0 \mathrm{E}-04 \\
1.0 \mathrm{E}-04 \\
1.0 \mathrm{E}-04 \\
1.0 \mathrm{E}-04 \\
1.0 \mathrm{E}-04\end{array}$ & $\begin{array}{l}7.0 \mathrm{E}-03 \\
7.0 \mathrm{E}-03 \\
7.0 \mathrm{E}-03 \\
7.0 \mathrm{E}-03 \\
7.0 \mathrm{E}-03\end{array}$ & $\begin{array}{l}7.0 \mathrm{E}-07 \\
7.0 \mathrm{E}-07 \\
7.0 \mathrm{E}-07 \\
7.0 \mathrm{E}-07 \\
7.0 \mathrm{E}-07\end{array}$ \\
\hline \multicolumn{7}{|c|}{ Alternative 3} \\
\hline $\begin{array}{l}\text { INEL } \\
\text { ORR }\end{array}$ & $\begin{array}{c}1.5 \mathrm{E}-07 \\
\mathrm{NA}\end{array}$ & $\begin{array}{l}1.8 \mathrm{E}-02 \\
1.8 \mathrm{E}-02\end{array}$ & $\begin{array}{c}2.7 \mathrm{E}-09 \\
\mathrm{NA}\end{array}$ & $\begin{array}{l}1.00 \mathrm{E}-04 \\
1.00 \mathrm{E}-04\end{array}$ & $\begin{array}{l}7.00 \mathrm{E}-03 \\
7.00 \mathrm{E}-03\end{array}$ & $\begin{array}{l}7.0 \mathrm{E}-07 \\
7.0 \mathrm{E}-07\end{array}$ \\
\hline
\end{tabular}

a $\mathrm{NA}=$ not applicable. 
TABLE F.17 Airplane Impacts Initiating Event Frequency: LLMW Storage Facilities $^{\mathrm{a}}$

\begin{tabular}{|c|c|c|c|c|c|c|}
\hline \multirow[b]{2}{*}{ DOE Site ${ }^{a}$} & \multicolumn{3}{|c|}{ APLL } & \multicolumn{3}{|c|}{ APLS } \\
\hline & $\begin{array}{c}\text { Crash } \\
\text { Frequency } \\
\left(\text { crash } / y r-\mathbf{m i}^{2}\right)\end{array}$ & $\begin{array}{l}\text { Area } \\
\left(\mathrm{mi}^{2}\right)\end{array}$ & $\begin{array}{c}\text { Initiating } \\
\text { Event } \\
\text { Frequency } \\
(\mathrm{yr}-1)\end{array}$ & $\begin{array}{c}\text { Crash } \\
\text { Frequency } \\
\left(\text { crash } / \mathrm{yr}-\mathrm{mi}^{2}\right)\end{array}$ & $\begin{array}{l}\text { Area } \\
\left(\mathrm{mi}^{2}\right)\end{array}$ & $\begin{array}{c}\text { Initiating } \\
\text { Event } \\
\text { Frequency } \\
\left(\mathbf{y r}^{-1}\right)\end{array}$ \\
\hline ANL-E & $\mathrm{NA}$ & $2.1 \mathrm{E}-02$ & NA & $1.0 \mathrm{E}-04$ & $7.0 \mathrm{E}-03$ & $7.0 \mathrm{E}-07$ \\
\hline BNL & NA & $2.1 E-02$ & NA & $1.0 \mathrm{E}-04$ & $7.0 \mathrm{E}-03$ & $7.0 \mathrm{E}-07$ \\
\hline ETEC & NA & $2.1 E-02$ & NA & $1.0 \mathrm{E}-04$ & $7.0 \mathrm{E}-03$ & $7.0 \mathrm{E}-07$ \\
\hline FEMP & $N A^{b}$ & $2.1 \mathrm{E}-02$ & NA & 1.0E-04 & 7.0E-03 & $7.0 \mathrm{E}-07$ \\
\hline Hanford & $6.5 \mathrm{E}-07$ & $2.1 \mathrm{E}-02$ & $1.4 \mathrm{E}-08$ & $1.0 \mathrm{E}-04$ & $7.0 \mathrm{E}-03$ & $7.0 \mathrm{E}-07$ \\
\hline INEL & $1.5 \mathrm{E}-07$ & $2.1 \mathrm{E}-02$ & $3.2 \mathrm{E}-09$ & $1.0 \mathrm{E}-04$ & $7.0 \mathrm{E}-03$ & $7.0 \mathrm{E}-07$ \\
\hline KAPL-S & NA & $2 \mathrm{1E}-02$ & NA & $1.0 \mathrm{E}-04$ & $7.0 \mathrm{E}-03$ & $7.0 \mathrm{E}-07$ \\
\hline LANL & NA & $2.1 \mathrm{E}-02$ & $\mathrm{NA}$ & $1.0 \mathrm{E}-04$ & $7.0 \mathrm{E}-03$ & $7.0 \mathrm{E}-07$ \\
\hline LBL & NA & $2.1 \mathrm{E}-02$ & NA & $1.0 \mathrm{E}-04$ & $7.0 \mathrm{E}-03$ & $7.0 \mathrm{E}-07$ \\
\hline LLNL & $\mathrm{NA}$ & $2.1 \mathrm{E}-02$ & $\mathrm{NA}$ & $1.0 \mathrm{E}-04$ & $7.0 \mathrm{E}-03$ & $7.0 \mathrm{E}-07$ \\
\hline Middlesex & NA & $2.1 \mathrm{E}-02$ & NA & $1.0 \mathrm{E}-04$ & $7.0 \mathrm{E}-03$ & $7.0 \mathrm{E}-07$ \\
\hline NTS & NA & $2.1 \mathrm{E}-02$ & $\mathrm{NA}$ & $1.0 \mathrm{E}-04$ & $7.0 \mathrm{E}-03$ & $7.0 \mathrm{E}-07$ \\
\hline ORR & NA & $2.1 \mathrm{E}-02$ & NA & $1.0 \mathrm{E}-04$ & $7.0 \mathrm{E}-03$ & $7.0 \mathrm{E}-07$ \\
\hline Pantex & $1.7 \mathrm{E}-05$ & $2.1 \mathrm{E}-02$ & $3.7 \mathrm{E}-07$ & $3.3 \mathrm{E}-04$ & $7.0 \mathrm{E}-03$ & $2.3 \mathrm{E}-06$ \\
\hline PGDP & NA & $2.1 \mathrm{E}-02$ & NA & $9.6 \mathrm{E}-04$ & $7.0 \mathrm{E}-03$ & $6.7 \mathrm{E}-06$ \\
\hline PORTS & $\mathrm{NA}$ & $2.1 \mathrm{E}-02$ & NA & $1.0 \mathrm{E}-04$ & $7.0 \mathrm{E}-03$ & $7.0 \mathrm{E}-07$ \\
\hline REETS & NA & $2.1 \mathrm{E}-02$ & NA & $7.6 \mathrm{E}-04$ & $7.0 \mathrm{E}-03$ & $5.3 \mathrm{E}-06$ \\
\hline SNL-NM & $1.6 \mathrm{E}-03$ & $2.1 \mathrm{E}-02$ & $3.4 \mathrm{E}-05$ & $1.0 \mathrm{E}-02$ & $7.0 \mathrm{E}-03$ & $7.0 \mathrm{E}-05$ \\
\hline SRS & $6.3 \mathrm{E}-07$ & $2.1 \mathrm{E}-02$ & $1.3 \mathrm{E}-08$ & $1.0 \mathrm{E}-04$ & $7.0 \mathrm{E}-03$ & $7.0 \mathrm{E}-07$ \\
\hline
\end{tabular}

a Abbreviations: BNL = Brookhaven National Laboratory, ETEC = Energy Technology Engineering Center, KAPL-S = Knolls Atomic Power Laboratory (Schenectady), LBL = Lawrence Berkeley Laboratory, and Middlesex $=$ Middlesex Sampling Plant.

b $\mathrm{NA}=$ not applicable.

TABLE F.18 Airplane Impacts Initiating Event Frequency: LLMW Treatment Facilities

\begin{tabular}{|c|c|c|c|c|c|c|}
\hline \multirow[b]{2}{*}{$\begin{array}{l}\text { DOE } \\
\text { Site }\end{array}$} & \multicolumn{3}{|c|}{ APLL } & \multicolumn{3}{|c|}{ APLS } \\
\hline & $\begin{array}{c}\text { Crash } \\
\text { Frequency } \\
\left(\text { crash/yr- } \mathrm{mi}^{2}\right)\end{array}$ & $\begin{array}{l}\text { Area } \\
\left(m i^{2}\right)\end{array}$ & $\begin{array}{l}\text { Initiating } \\
\text { Event } \\
\text { Frequency } \\
\left(\mathrm{yr}^{-1}\right)\end{array}$ & $\begin{array}{c}\text { Crash } \\
\text { Frequency } \\
\left(\text { crash } / y r-\mathrm{mi}^{2}\right)\end{array}$ & $\begin{array}{l}\text { Area } \\
\left(\mathrm{mi}^{2}\right)\end{array}$ & $\begin{array}{l}\text { Initiating } \\
\text { Event } \\
\text { Frequency } \\
\left(\mathrm{yr}^{-1}\right)\end{array}$ \\
\hline FEMP & $\mathrm{NA}^{\mathrm{a}}$ & $1.8 \mathrm{E}-02$ & NA & $1.0 \mathrm{E}-04$ & $7.0 \mathrm{E}-03$ & $7.0 \mathrm{E}-07$ \\
\hline Hanford & $6.5 E-07$ & $1.8 \mathrm{E}-02$ & $1.2 \mathrm{E}-08$ & $1.0 \mathrm{E}-04$ & $7.0 \mathrm{E}-03$ & $7.0 \mathrm{E}-07$ \\
\hline INEL & $1.5 \mathrm{E}-07$ & $1.8 \mathrm{E}-02$ & $2.7 \mathrm{E}-09$ & $1.0 \mathrm{E}-04$ & 7.0E-03 & $7.0 \mathrm{E}-07$ \\
\hline LANL & NA & $1.8 \mathrm{E}-02$ & $\mathrm{NA}$ & $1.0 \mathrm{E}-04$ & $7.0 \mathrm{E}-03$ & $7.0 \mathrm{E}-07$ \\
\hline LLNL & NA & $1.8 \mathrm{E}-02$ & NA & $1.0 \mathrm{E}-04$ & $7.0 \mathrm{E}-03$ & $7.0 \mathrm{E}-07$ \\
\hline ORR & NA & $1.8 \mathrm{E}-02$ & NA & $1.0 \mathrm{E}-04$ & $7.0 \mathrm{E}-03$ & $7.0 \mathrm{E}-07$ \\
\hline Pantex & $1.7 \mathrm{E}-05$ & $1.8 \mathrm{E}-02$ & $3.1 \mathrm{E}-07$ & 3.3E-04 & $7.0 \mathrm{E}-03$ & $2.3 E-06$ \\
\hline PGDP & NA & $1.8 \mathrm{E}-02$ & NA & $9.6 \mathrm{E}-04$ & $7.0 \mathrm{E}-03$ & $6.7 \mathrm{E}-06$ \\
\hline PORTS & NA & $1.8 \mathrm{E}-02$ & NA & $1.0 \mathrm{E}-04$ & $7.0 \mathrm{E}-03$ & $7.0 \mathrm{E}-07$ \\
\hline RFETS & NA & $1.8 \mathrm{E}-02$ & NA & $7.6 \mathrm{E}-04$ & $7.0 \mathrm{E}-03$ & $5.3 \mathrm{E}-06$ \\
\hline SRS & $6.3 \mathrm{E}-07$ & $1.8 \mathrm{E}-02$ & $1.1 \mathrm{E}-08$ & $1.0 \mathrm{E}-04$ & $7.0 \mathrm{E}-03$ & $7.0 \mathrm{E}-07$ \\
\hline
\end{tabular}

a $\mathrm{NA}=$ not applicable. 
TABLE F.19 Airplane Impacts Initiating Event Frequency: TRUW Storage Facilities

\begin{tabular}{|c|c|c|c|c|c|c|}
\hline \multirow[b]{2}{*}{$\begin{array}{l}\text { DOE } \\
\text { Site }^{\mathrm{a}}\end{array}$} & \multicolumn{3}{|c|}{ APLL } & \multicolumn{3}{|c|}{ APLS } \\
\hline & $\begin{array}{c}\text { Crash } \\
\text { Frequency } \\
\left(\text { crash/yr-mi }{ }^{2}\right)\end{array}$ & $\begin{array}{l}\text { Area } \\
\left(\mathrm{mi}^{2}\right)\end{array}$ & $\begin{array}{l}\text { Initiating } \\
\text { Event } \\
\text { Frequency } \\
\left(\mathrm{yr}^{-1}\right)\end{array}$ & $\begin{array}{c}\text { Crash } \\
\text { Frequency } \\
\left(\text { crash/yr-mi }{ }^{2}\right)\end{array}$ & $\begin{array}{l}\text { Area } \\
\left(m i^{2}\right)\end{array}$ & $\begin{array}{c}\text { Initiating } \\
\text { Event } \\
\text { Frequency } \\
\left(\mathrm{yr}^{-1}\right)\end{array}$ \\
\hline ANL-E & $\mathrm{NA}^{\mathrm{b}}$ & 2.1E-02 & NA & $1.0 \mathrm{E}-04$ & $7.0 \mathrm{E}-03$ & $7.0 \mathrm{E}-07$ \\
\hline Hanford & $6.5 \mathrm{E}-07$ & 2.1E-02 & $1.4 \mathrm{E}-08$ & $1.0 \mathrm{E}-04$ & $7.0 \mathrm{E}-03$ & $7.0 \mathrm{E}-07$ \\
\hline INEL & $1.5 \mathrm{E}-07$ & 2.1E-02 & $3.2 \mathrm{E}-09$ & $1.0 \mathrm{E}-04$ & $7.0 \mathrm{E}-03$ & $7.0 \mathrm{E}-07$ \\
\hline LANL & NA & 2.1E-02 & NA & $1.0 \mathrm{E}-04$ & $7.0 \mathrm{E}-03$ & $7.0 \mathrm{E}-07$ \\
\hline LLNL & NA & 2.1E-02 & NA & $1.0 \mathrm{E}-04$ & $7.0 \mathrm{E}-03$ & $7.0 \mathrm{E}-07$ \\
\hline Mound & $\mathrm{NA}$ & 2.1E-02 & $\mathrm{NA}$ & $1.0 \mathrm{E}-04$ & $7.0 \mathrm{E}-03$ & $7.0 \mathrm{E}-07$ \\
\hline NTS & $\mathrm{NA}$ & $2.1 \mathrm{E}-02$ & $\mathrm{NA}$ & $1.0 \mathrm{E}-04$ & $7.0 \mathrm{E}-03$ & $7.0 \mathrm{E}-07$ \\
\hline ORR & NA & 2.1E-02 & NA & 1.0E-04 & $7.0 \mathrm{E}-03$ & $7.0 \mathrm{E}-07$ \\
\hline RFETS & NA & $2.1 E-02$ & NA & 7.6E-04 & $7.0 \mathrm{E}-03$ & $5.3 \mathrm{E}-06$ \\
\hline SRS & $6.3 \mathrm{E}-07$ & 2.1E-02 & $1.3 \mathrm{E}-08$ & $1.0 \mathrm{E}-04$ & $7.0 \mathrm{E}-03$ & $7.0 \mathrm{E}-07$ \\
\hline
\end{tabular}

a Abbreviation: Mound = Mound Plant.

b $\mathrm{NA}=$ not applicable.

TABLE F.20 Airplane Impacts Initiating Event Frequency: TRUW Treatment Facilities

\begin{tabular}{|c|c|c|c|c|c|c|}
\hline \multirow[b]{2}{*}{$\begin{array}{l}\text { DOE } \\
\text { Site }^{\mathbf{a}}\end{array}$} & \multicolumn{3}{|c|}{ APLL } & \multicolumn{3}{|c|}{ APLS } \\
\hline & $\begin{array}{c}\text { Crash } \\
\text { Frequency } \\
\left(\text { crash/yr-mi }{ }^{2}\right)\end{array}$ & $\begin{array}{l}\text { Area } \\
\left(\mathrm{mi}^{2}\right)\end{array}$ & $\begin{array}{c}\text { Initiating } \\
\text { Event } \\
\text { Frequency }\left(\mathrm{yr}^{-1}\right)\end{array}$ & $\begin{array}{c}\text { Crash } \\
\text { Frequency } \\
\left(\text { crash/yr-mi }{ }^{2}\right)\end{array}$ & $\begin{array}{l}\text { Area } \\
\left(\mathrm{mi}^{2}\right)\end{array}$ & $\begin{array}{c}\text { Initiating } \\
\text { Event } \\
\text { Frequency/yr }\end{array}$ \\
\hline Hanford & $6.5 \mathrm{E}-07$ & $1.8 \mathrm{E}-02$ & $1.2 \mathrm{E}-08$ & $1.0 \mathrm{E}-04$ & $7.0 \mathrm{E}-03$ & $7.0 \mathrm{E}-07$ \\
\hline INEL & $1.5 \mathrm{E}-07$ & $1.8 \mathrm{E}-02$ & $2.7 \mathrm{E}-09$ & $1.0 \mathrm{E}-04$ & $7.0 \mathrm{E}-03$ & $7.0 \mathrm{E}-07$ \\
\hline LANL & $\mathbf{N A}^{\mathrm{b}}$ & $1.8 \mathrm{E}-02$ & NA & $1.0 \mathrm{E}-04$ & $7.0 \mathrm{E}-03$ & $7.0 \mathrm{E}-07$ \\
\hline REETS & NA & $1.8 \mathrm{E}-02$ & NA & $7.6 \mathrm{E}-04$ & $7.0 \mathrm{E}-03$ & $5.3 E-06$ \\
\hline SRS & $6.3 \mathrm{E}-07$ & $1.8 \mathrm{E}-02$ & 1. $1 \mathbf{E}-08$ & $1.0 \mathrm{E}-04$ & 7.0E-03 & $7.0 \mathrm{E}-07$ \\
\hline WIPP & NA & $1.8 \mathrm{E}-02$ & NA & $1.0 \mathrm{E}-04$ & 7.0E-03 & $7.0 \mathrm{E}-07$ \\
\hline
\end{tabular}

a Abbreviation: WIPP $=$ Waste Isolation Pilot Plant.

b $\mathrm{NA}=$ not applicable. 


\section{F.5 REFERENCES}

Chelapati, C.V., et al., 1972, "Probabilistic Assessment of Aircraft Hazards for Nuclear Power Plants," Nuclear Engineering and Design 19:333-346.

Eisenhut, D.G., 1972, General Aviation Fatal Crash Probability Distribution for Use in Nuclear Reactor Siting, U.S. Atomic Energy Commission, Washington D.C.

Eisenhut, D.G., 1973, "Reactor Siting in the Vicinity of Airfields," in Transactions of the American Nuclear Society 1973 Annual Meeting, American Nuclear Society, La Grange, Ill.

Feizollahi, F., and D. Shropshire, 1992, Waste Management Facilities Cost Information Report, EGG-WTD-10443, EG\&G Idaho, Idaho Falls, Idaho, Oct.

Kot, C.A., et al., 1982, Evaluation of Aircraft Crash Hazards Analyses for Nuclear Power Plants, NUREG/CR-2859, ANL-CT-81-32, U.S. Nuclear Regulatory Commission, Washington, D.C.

U.S. Department of Energy, 1995, Office of Waste Management Programmatic Environmental Impact Statement, Draft, Washington, D.C.

U.S. Nuclear Regulatory Commission, 1975, Reactor Safety Study, WASH-1400, Washington, D.C.

U.S. Nuclear Regulatory Commission, 1981, Standard Review Plan: Aircraft Hazards, Section 3.5.1.6, rev. 2, NUREG-0800, Washington, D.C.

Wall, I.B., 1974, "Probabilistic Assessment of Aircraft Risk for Nuclear Power Plants," Nuclear Safety 15(3):276-284. 
APPENDIX G:

MODELING OF EXTERNAL EVENTS 


\section{CONTENTS}

NOTATION

G.1 INTRODUCTION

G.2 STORAGE FACILITY ACCIDENTS $\ldots \ldots \ldots \ldots \ldots \ldots \ldots \ldots$ G-8

G.2.1 Specification and Frequency Evaluation of Accident Sequences . . . . . . . G-8

G.2.2 Evaluation of Source Term Parameters . . . . . . . . . . . . . G-15

G.3 TREATMENT FACILITY ACCIDENTS $\ldots \ldots \ldots \ldots \ldots \ldots \ldots \ldots$ G-17

G.3.1 Specification and Frequency Evaluation of Accident Sequences . . . . . . . G-17

G.3.2 Evaluation of Source Term Parameters for Treatment Facilities . . . . . . . G-22

G.4 REFERENCES $\ldots \ldots \ldots \ldots \ldots \ldots \ldots \ldots \ldots \ldots \ldots \ldots \ldots \ldots \ldots$. . . . . . . . . . . . . . . .

\section{TABLE}

G.1 Approximate Distribution of Incinerator Ash in the Generic Facility

\section{FIGURES}

G.1 Event Tree for Small-Aircraft Impact on Generic Storage Facility with No Confinement

G.2 Event Tree for Large-Aircraft Impact on Generic Storage Facility with No Confinement

G.3 Event Tree for Seismic Challenge to Generic Storage Facility with No Confinement

G.4 Event Tree for Small-Aircraft Impact on Generic DOE Hazard Category 2 Incineration Facility

G.5 Event Tree for Large-Aircraft Impact on Generic DOE Hazard Category 2 Incineration Facility

G.6 Event Tree for Seismic Challenge to Generic DOE Hazard Category 2 Incineration Facility 


\section{NOTATION}

The following is a list of acronyms, initialisms, and abbreviations (including units of measure) used in this appendix.

\section{ACRONYMS, INITIALISMS, AND ABBREVIATIONS}

CBD integrity of secondary containment

CIF Consolidated Incineration Facility

DET severity of explosion

DF damage fraction

DOE U.S. Department of Energy

EXP occurrence of explosions involving waste

FR occurrence of fire

HEPA high-efficiency particulate air (filter)

HW hazardous waste

LLMW low-level mixed waste

LLW low-level waste

MAR material at risk

PBB integrity of primary containment

PRL pressurized release

PRP propagation to adjacent area

RARF respirable airborne release fraction

SCC secondary combustion chamber

SFR severity of fire

TRUW transuranic waste

WERF Waste Experimental Reduction Facility

\section{UNITS OF MEASURE}

$\begin{array}{ll}\text { h } & \text { hour(s) } \\ \text { kg } & \text { kilogram(s) } \\ \text { lb } & \text { pound(s) }\end{array}$




\section{APPENDIX G:}

\section{MODELING OF EXTERNAL EVENTS}

\section{G.1 INTRODUCTION}

This appendix evaluates the frequencies and source terms for the accidents caused by external initiators. The results were used primarily to provide an early screening of storage and staging area accidents but were also used to provide the source terms for incineration accidents for subsequent health effects calculations. Because storage facility accidents for LLW, LLMW, and TRUW do not discriminate among alternatives, the event trees were not used to calculate health effects. They were, however, used to select limiting accident sequences for hazardous waste storage and staging facilities.

External event challenges are important to the human health risk from radiological releases insofar as they have the potential to create major spills, fires, or explosions that can disperse and render airborne radioactive waste materials. Plausible external accident initiators leading to direct fire and explosion scenarios include impacts from military, general aviation, or commercial aircraft; impacts from large trucks carrying fuel or chemicals; and fuel or process chemical fires and explosions in nearby facilities or storage tanks. Natural phenomena such as earthquakes can cause waste spills and natural gas, fuel, or process chemical fires and explosions in nearby facilities. The severity of such phenomena makes mitigation by on-site fire brigades unlikely.

Event trees are used to model the accidents and to project the progression of the accidents through plausible generic sequences. These sequences are developed for aircraft impacts (small and large aircraft are considered separately) and seismic events. The safety impacts of aircraft accidents envelop impacts for other man-made severe external challenges; the damage and safety impacts from seismic events envelop effects from other natural phenomena. These accident initiators and the associated accident sequences are developed for the designs for the generic facilities described in Section 2.5 of this document.

The event trees presented in this section are generally applicable to low-level mixed waste (LLMW), low-level waste (LLW), and transuranic waste (TRUW); however, the values for conditional failure probability were based on LLW. The appropriate adjustments for the conditional failure probabilities needed to address LLMW and TRUW are discussed in the text or noted on the event trees. A single sequence from the event trees was selected for analysis for hazardous waste (HW). External event results are covered in the sections addressing specific waste types.

The event trees presented in this section are based on accepted probabilistic risk assessment methods and are consistent with methods prescribed by the U.S. Nuclear Regulatory Commission, the American Institute of Chemical Engineers, and the U.S. Department of Energy (DOE). Because the event trees are generic, all of the top (conditional) events that are used for all types of accidents are included in all of the event trees. Top events that are not developed (i.e., no branch exists) are either not applicable or effectively assumed to occur in the sequence (i.e., the conditional failure probability is 1.0 ). As shown in the event trees, the individual sequences are named, and the associated 
conditional failure probabilities and damage fractions are also given. A release class that is used for "bookkeeping" in handling the results is also included. The accident sequence column is used to show which conditional failure events (e.g., integrity of secondary containment [CBD1], integrity of primary containment [PBB2], etc.) are included in the sequence. The success events are not shown; however, the frequencies of accident sequences include the probabilities of the success branches. The lower (failure) branch generally indicates that the failure or higher consequence of the top event occurs, while the upper (success) branch indicates that the top event does not occur or occurs with lesser consequence.

\section{G.2 STORAGE·FACILITY ACCIDENTS}

\section{G.2.1 Specification and Frequency Evaluation of Accident Sequences}

Event trees were developed to structure and facilitate a screening evaluation of the extermal event sequences for storage facilities. The first group of sequences considered is shown in Figure G.1, which illustrates the accident progression for the initiation of major fires in storage areas hit by small aircraft. These event trees also apply to impacts from large trucks carrying fuel or chemicals or from propagation of fires or explosions from nearby facilities. Sequences from these initiators would tend to have similar likelihoods of accident progression and lead to similar source term releases.

The second set of sequences is shown in Figure G.2, which illustrates the accident progression for the initiation of major accidents in storage areas hit by large commercial aircraft. The third set of sequences is shown in Figure G.3, which illustrates the accident sequences in storage areas for accidents initiated by seismic events. As discussed in Section 2.3 of the main text, effects from other dominant natural phenomena, like severe winds and tornadoes, can be enveloped by effects depicted for seismic events. The initiating frequencies for external event sequences are site-dependent for natural phenomena. For aircraft impacts, initiating frequencies are both site- and facility-dependent.

As discussed in Section 2.5 of the text of this document, containment systems for generic storage facilities do not conform to any of the standard DOE structural performance goals; consequently, it has been assumed that natural phenomena will have the potential to cause damage and release hazardous materials. Because the same generic design is assumed to be used at all DOE sites and because the frequency of natural phenomena of a particular severity varies from site to site, the frequency of damage from seismic and wind events is site-dependent. The frequency of aircraft impacts is also site-dependent because the frequency is a function of the proximity to general and commercial airways and airports.

The probabilities assigned to the various accident progression branches are a function of (1) the initiating event and its magnitude and corresponding impact on the storage facility and material at risk (MAR) and (2) the sequence of events preceding the branch to be evaluated, and its expected impact on the facility and MAR. In general, conservative but reasonable assumptions have been made. The probabilities assigned are shown on the event trees and are discussed subsequently. 


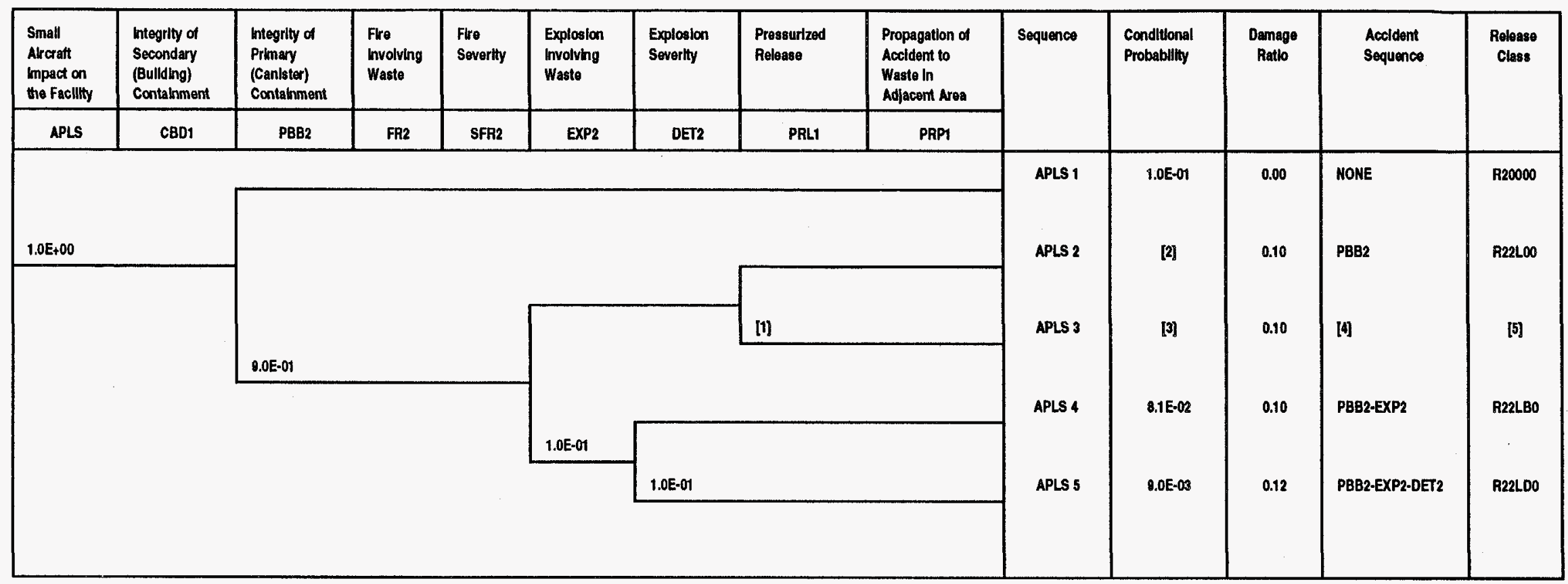

FIGURE G.1 Event Tree for Small-Aircraft Impact on Generic Storage Facility with No Confinement [6]

[1] Because of the general absence of liquids in storage, the estimated probability of a pressurized release for LLW and TRUW is assumed to be 0 . For LLMW, where liquids (many organic-based) are present in general, the likelihood of a pressurized release with a severe fire is estimated to be 0.01 .

[2] The conditional probability depends on waste type.

[3] The conditional probability depends on waste form and does not apply to LLW and TRUW.

[4] This accident sequence does not occur for LLW and TRUW. The sequence is PBB2-PRL1 for LLMW.

[5] The release class is only relevant for LLMW and is R22L01.

[6] A single sequence, APLS-2, was used for hazardous waste. 


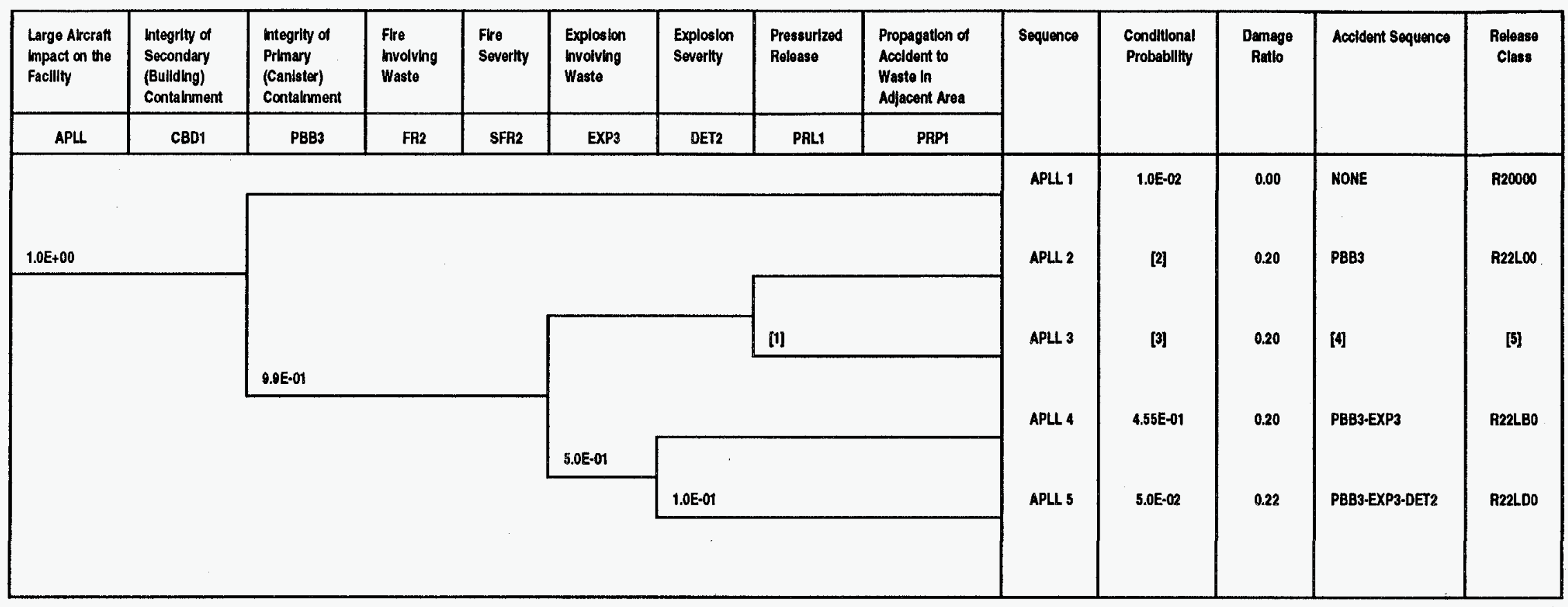

FIGURE G.2 Event Tree for Large-Aircraft Impact on Generic Storage Facility with No Confinement [6]

[1] Because of the general absence of liquids in storage, the estimated probability of a pressurized release for LLW and TRUW is assumed to be 0. For LLMW, where liquids (many organic-based) are present in general, the likelihood of a pressurized release with a severe fire is estimated to be 0.01 .

[2] The conditional probability depends on waste type.

[3] The conditional probability depends on waste form and does not apply to LLW and TRUW.

[4] This accident sequence does not occur for LLW and TRUW. The sequence is PBB3-PRL1 for LLMW.

[5] The release class is only relevant for LLMW and is R22L01.

[6] A single sequence, APLL-2, was used for hazardous waste. 


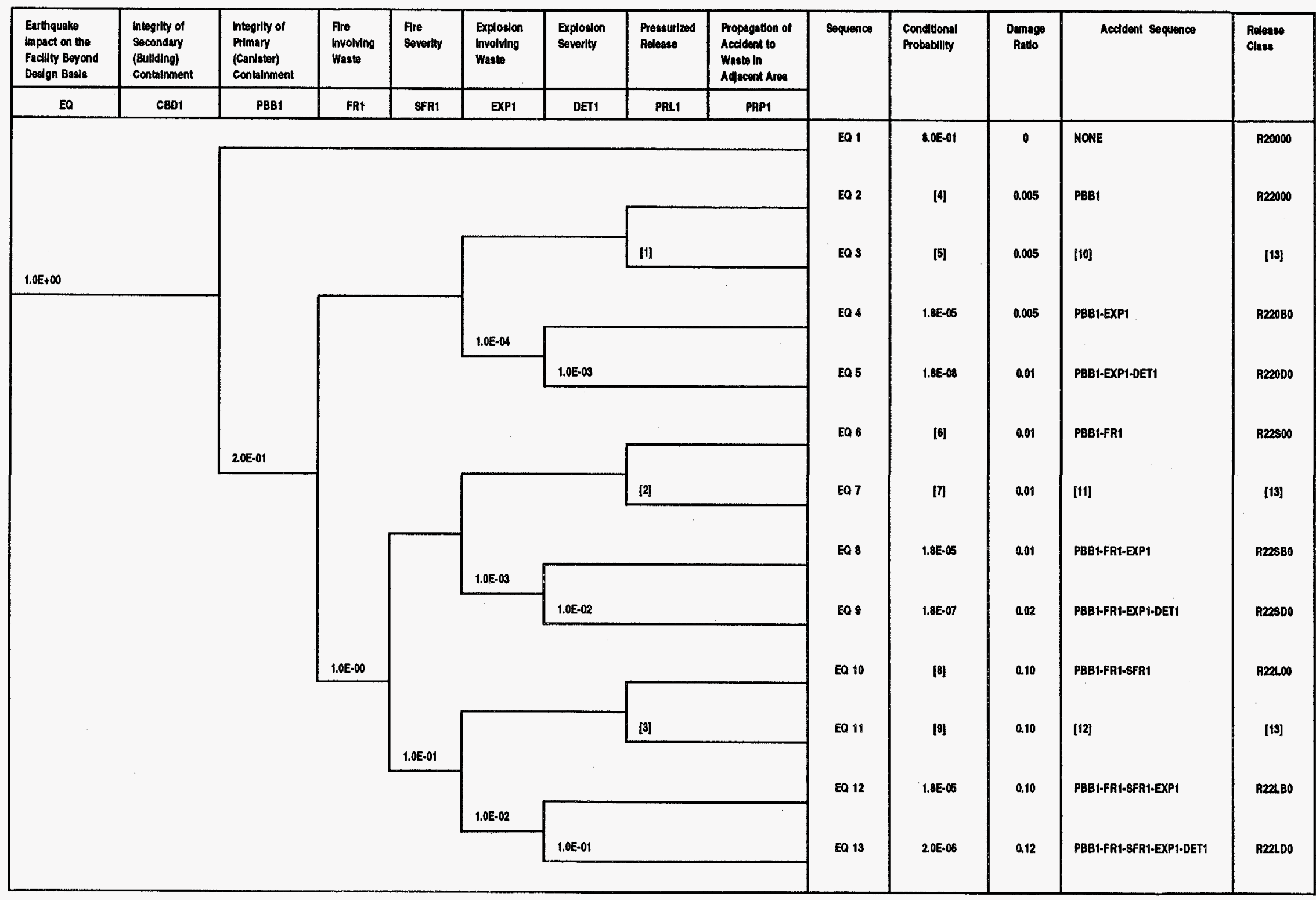

FIGURE G.3 Event Tree for Seismic Challenge to Generic Storage Facility with No Confinement [14]

See next page for footnotes. 
[1] Because of the general absence of liquids in storage, the estimated probability of a pressurized release for LLW and TRUW is assumed to be 0. For LLMW, where liquids (many organic-based) are present in general, the likelihood of a pressurized release with no fire is estimated at 1.0E-04.

[2] The probability of a pressurized release is 0 for LLW and TRUW because the absence of liquids in storage. For LLMW, the probability is estimated at $1.0 \mathrm{E}-03$ in the presence of a moderate fire.

[3] The probability of a pressurized release is still 0 for LLW and TRUW because of the absence of liquids in storage. For LLMW, the probability is estimated at 0.01 in the presence of a severe fire.

[4] The conditional probability depends on waste type.

[5] The conditional probability depends on waste form and is not applicable to LLW and TRUW.

[6] The conditional probability depends on waste type.

[7] The conditional probability depends on waste type and can range from -0 to $1.8 \mathrm{E}-05$.

[8] The conditional probability depends on waste type.

[9] The conditional probability depends on waste type and can range from 0 to 2.0E-05.

[10] This accident sequence does not occur for LLW and TRUW. The sequence is PBB1-PRL3 for LLMW.

[11] This accident sequence does not occur for LLW and TRUW. The sequence is PBB1-FR1-PRL3 for LLMW.

[12] This accident sequence does not occur for LLW and TRUW. The sequence is PBB1-FR1-SFR1PRL3 for LLMW.

[13] The release class is only relevant for LLMW and is R22001 for EQ3, R22S01 for EQ7, and R22L01 for EQ11.

[14] A single sequence, equivalent to $\mathrm{EQ}-2$, is used for hazardous waste. 


\section{G.2.1.1 Integrity of Secondary Containment (CBD)}

Storage facilities have been assumed to lack formal containment; the implied probability of the failure of the secondary confinement is 1.0 for all three types of external event initiators.

\section{G.2.1.2 Integrity of Primary Containment (PBB)}

For events caused by natural phenomena, it has been assumed that drums drop to the floor, either because of the direct impact of the initiator or because of the impact of structural elements falling on the drums. While the actual probability would strongly depend on the storage array and the details of the structure, it has been assumed that, on average, the probability that drums fall to the floor and leak is 0.1 and the probability that structural elements or projectiles puncture one or more drums is 0.1 . Thus, the conditional probability assigned is 0.2. For aircraft impacts or nearby explosions, the likelihood of drum breach is very high. It has been assumed that the likelihood is 0.9 for small aircraft (very likely) and 0.99 for large aircraft (almost certain).

\section{G.2.1.3 Occurrence of Fire (FR)}

For aircraft-crash external events, fires have been assumed to occur. For earthquakes, the conditional probability for the occurrence of a sustained fire in a storage facility is obviously a function of the content of the waste containers and the physical characteristics of the facility. Containers of TRUW already under pressure from gas buildup would have a finite probability of spontaneous ignition under shock from impact or crushing events associated with seismic shaking. For LLMW and LLW containers, for which such mechanistic forces are hard to identify, the probability would be much less. Similarly, unless the affected waste is combustible, the ability of a fire to sustain itself in the absence of a combustible source is hard to rationalize.

Important facility characteristics include the presence of (1) natural-gas or chemical process piping that could be sheared during the seismic event; (2) fuel or chemical process storage tanks that could be ignited and are located in or near the storage facility; (3) vehicles with fuel tanks that could be ignited under crush or impact. In the absence of site-specific information, the following assumptions were used to generically assess the likelihood of fires in storage facilities. Facilities storing combustibles in packaged containers or drums were assigned a minimum probability of 0.1 of having a fire initiated by seismic shaking. General purpose buildings used for storage of combustibles were assigned a minimum probability of 0.2 for fires to account for the greater likelihood of coherent sources of combustible materials in the facility. For storage pads or general purpose buildings storing noncombustibles, the minimum probabilities of fire were reduced by a factor of 10 to 0.01 and 0.02 , respectively. For aircraft crashes, with the additional source for fuel, a fire was assumed to occur. 


\section{G.2.1.4 Severity of Fire (SFR)}

Fire resistant packaging is used for combustibles of all types. Thus, for a severe fire to sustain itself, large sources of fuel from within or nearby, (e.g., large fuel tanks or chemical process tanks) are required. To account for this possibility, the conservative assumption was made that a minimum of $10 \%$ of the sustained fire sequences in storage facilities storing combustibles would involve severe fire that would challenge the entire facility after an earthquake. All sustained fires in facilities storing noncombustibles were assumed to arise from ignition of external fuel or chemical sources, and thus the conditional probability that the fire was severe was conservatively assumed to be 1.0 for aircraft crashes.

\section{G.2.1.5 Occurrence of Explosions Involving Waste (EXP)}

The event trees for natural phenomena show the occurrence of an explosion in the absence of a fire, in the presence of a small fire, and in the presence of a severe fire. The conditional probabilities have been assigned as a function of these three situations, assuming that the higher the stresses (presence and severity of a fire), the higher the probability of inducing an explosion in the waste containers. Almost no information exists on the probability of induced explosions in storage facilities. In storage of $\mathrm{HW}$, an estimated $2 \%$ chance that a large fire will induce a large explosion has been reported (EG\&G 1990). In LLW storage, where a large fraction of the waste may be noncombustible, the probability would be expected to be lower. A value of 0.01 in the presence of a severe fire has been conservatively assigned. In the presence of small fires, the value is reduced by an order of magnitude; for no fires, the number is reduced by a factor of 100 . The situation changes for aircraft or fuel truck impacts, where a large fire is assumed to take place and where the incoming vehicle adds fuel materials that are likely to increase the probability of explosions. A value of 0.1 is used for small aircraft and 0.5 for large aircraft, to account for the possibility that the explosion will occur in the fuel tanks of the airplane.

\section{G.2.1.6 Severity of Explosion (DET)}

The severity of the explosion refers to the differentiation between a deflagration or a detonation. Unfortunately, no generic or facility-specific information has been found to assess the likelihood of a detonation given that an explosion has occurred. A detonation is thought to be more capable of dispersing material than a deflagration. The expectation is that the likelihood of a detonation will be a function of the material involved in the explosion and the type of container in use. While differentiation of these two characteristics is beyond the scope of a generic analysis for an environmental impact statement, the selection of the explosion severity affects the respirable airborne release fraction (RARF) for the accident. It has been assumed that the probability of a detonation depends on the severity of the accident leading to the explosion, and 1 in 10 explosions is likely to be a detonation in the presence of a large fire. The likelihood is decreased by one and two orders of magnitude for small fires and for no fires, respectively; both of these situations appear for natural phenomena. 


\section{G.2.1.7 Pressurized Release (PRL)}

Pressurized releases apply only to liquids that can be vaporized and released in vapor or aerosol form from their containers. For solid waste, an accident stress from impact is analogous to the liquid pressurized release. The inventory data for LLW and TRUW storage and generation indicated that liquid LLW and TRUW are rarely found in storage facilities. Liquid LLW was only a very small fraction of the total LLW sent to storage areas. In the very few places where the amount of liquid LLW in long-term storage was significant, it amounted to no more than $10 \%$ of the total LLW in volume and less than $30 \%$ in radioactivity. Pressurized release in LLW and TRUW was assigned a probability of 0.

For LLMW, a large fraction of the volume in storage is in liquid form, with many waste streams containing organic liquids. For LLMW, therefore, pressurized releases are possible. Because the likelihood of the pressurized release will depend on the heat stress applied to the waste container, the probability of pressurized release is proportional to the accident stress. In the absence of a fire, the probability is considered very unlikely; a value of 1.0E-04 has been assigned. In the presence of a fire, the probability is higher $-1.0 \mathrm{E}-03$ for small fires and 1.0E-02 for severe fires.

For HW, where liquid wastes (often organic liquids) are the norm, pressurized releases have been included in the scenarios identified (miscellaneous accidents that include container pressurization caused by loading errors; see Section 8 of main text). The pressurized releases for HW are therefore limited to the handling accidents. For external events, a single sequence for source term characterization has been chosen for each initiator (namely a fire after aircraft crashes and a spill after an earthquake); pressurized releases have not been included.

\section{G.2.1.8 Propagation to Adjacent Area (PRP)}

For a generic storage facility, no decisions on the number of pads and the distance between the pads will be made. Therefore, the assumptions are that all of the waste is stored in the same pad and that propagation is irrelevant. The amount of material affected is accounted for by the selection of the MAR, and the event tree parameters (damage ratio, release class) apply to the entire facility MAR.

\section{G.2.2 Evaluation of Source Term Parameters}

For outdoor pads or weather protection facilities, the MAR is essentially the inventory at the pad. The damage fractions (DFs) are a function of the accident sequence, with greater stresses resulting in higher DFs. Severe fire sequences would be likely to involve all of the packages; the DF would then be influenced by the frequency of package breach and the combustibility of the waste product. Explosions would be expected to cause drum or package breach but would tend to disperse the packages. These factors would have conflicting impacts on DFs. The RARFs are a function of the accident sequences and the 
physical form of the waste as discussed in Appendix D. The estimated DFs for the various sequences are summarized on the event trees. The justification for the numbers used is provided in the following paragraphs.

Although the inventories, physical forms, and radiological compositions of wastes stored at each site were characterized in the WM PEIS, compilation of this information for individual facilities on each site was beyond the scope of the PEIS. As a result, proper use of the event trees to characterize potential source terms for storage facilities requires either facility-specific inventory and packaging information or the use of assumptions. The assumptions used in the hazardous waste analyses are described in the $\mathrm{HW}$ accident sections.

\section{G.2.2.1 Seismic Events}

For sequences with only mechanical stresses, it has been assumed that $10 \%$ of the drums may fall or be impacted by structural elements (the actual value would strongly depend on the storage configuration and the severity of the accident stress). For containers that are dropped or impacted, it has been assumed that $10 \%$ will be breached and that on average, $50 \%$ of the contents of breached drums will be spilled. Thus, the DF is 0.005 . For sequences with an explosion (in the absence of a fire), it has been assumed that containers near those that have ruptured can also be breached if the explosion is severe enough. Thus, the DF was increased to 0.01 for detonation sequences without a fire. If a small fire occurs, adjacent containers can also be affected; thus, the damage fraction was increased to 0.01 . If, in addition to the small fire, a detonation occurs, additional nearby containers are assumed to be breached; the damage fraction was increased to 0.02 . For sequences with large fires, a significant number of containers are likely to be involved. The damage fraction assigned is 0.1 (and 0.12 if a detonation also occurs).

\section{G.2.2.2 Small Aircraft}

The relevant sequences involve severe fires, which have been assumed to involve a significant fraction ( 0.1 ) of the facility. If a detonation occurs, an additional $2 \%$ of the waste containers have been assumed to be breached, for a total damage ratio of 0.12 .

\section{G.2.2.3 Large Aircraft}

Because of the possible large amount of fuel provided by the aircraft, a larger fraction of the facility has been assumed to be affected by the severe fire. The damage fraction is estimated to be 0.2 . As with the other initiators, an additional $2 \%$ of containers have been assumed to be affected by a detonation. 


\section{G.3 TREATMENT FACHITY ACCWENTS}

\section{G.3.1 Specification and Frequency Evaluation of Accident Sequences}

Event trees were developed to structure and facilitate the evaluation of the external event sequences for incineration facilities. The first set of sequences (Figure G.4) corresponds to accident sequences initiated by impacts with small aircraft. Impacts caused by large aircraft result in the sequences shown in Figure G.5. Seismic event sequences are shown in Figure G.6 and are assumed to envelop the risk of sequences from other natural phenomena.

As discussed in Section 2.5 of this report, all incineration facilities have been assumed to meet the requirements of a Hazard Category 2 facility and to have the same performance goal (i.e., same building and equipment response to a natural phenomena) and exceedance frequency for external events, independent of the site. Thus, the initiating event frequency used for natural phenomena will be independent of the sites; however, the natural phenomenon severity for which the facility will be designed will be site-dependent. The frequency of aircraft impacts is site-dependent. The probabilities assigned to the various accident progression branches are a function of the initiating event and the sequence of events preceding the branches to be evaluated. The probabilities assigned are summarized on the event trees. The rationale for these values is given in the following paragraphs.

\section{G.3.1.1 Integrity of Secondary Containment (CBD)}

The performance goal (i.e., the annual probability of exceedance of facility damage as a result of a natural phenomena event) is a function of the annual probability of the exceedance of the event and the safety factors included in the facility design. For the incineration facility, which is assumed to be a Hazard Category 2 facility, the conditional probability of containment failure under natural phenomena has been assigned such that, when multiplied by the recommended design-basis frequency from Kennedy et al. (1990), the performance goal is met. For seismic events, the frequency is $1.0 \mathrm{E}-03 / \mathrm{yr}$ and the performance goal is $1.0 \mathrm{E}-04 / \mathrm{yr}$. Therefore, a conditional probability of 0.1 is used for seismic events. It has been assumed that the stresses on the structure caused by small-aircraft impacts are similar to those of natural phenomena and the same value of 0.1 has been used for the failure of the confinement. The probability of containment breach in this case is expected to be dominated by the massive airplane parts (mostly the engines) because lighter aircraft components may or may not penetrate the building (in general, the reinforced concrete walls of a Hazard Category 2 facility will protect the facility from projectiles and fuel fires, except for a direct crash onto the roof); however, for large aircraft, the likelihood of containment breach is assumed to be higher, and a conditional probability of 0.5 has been assigned. 


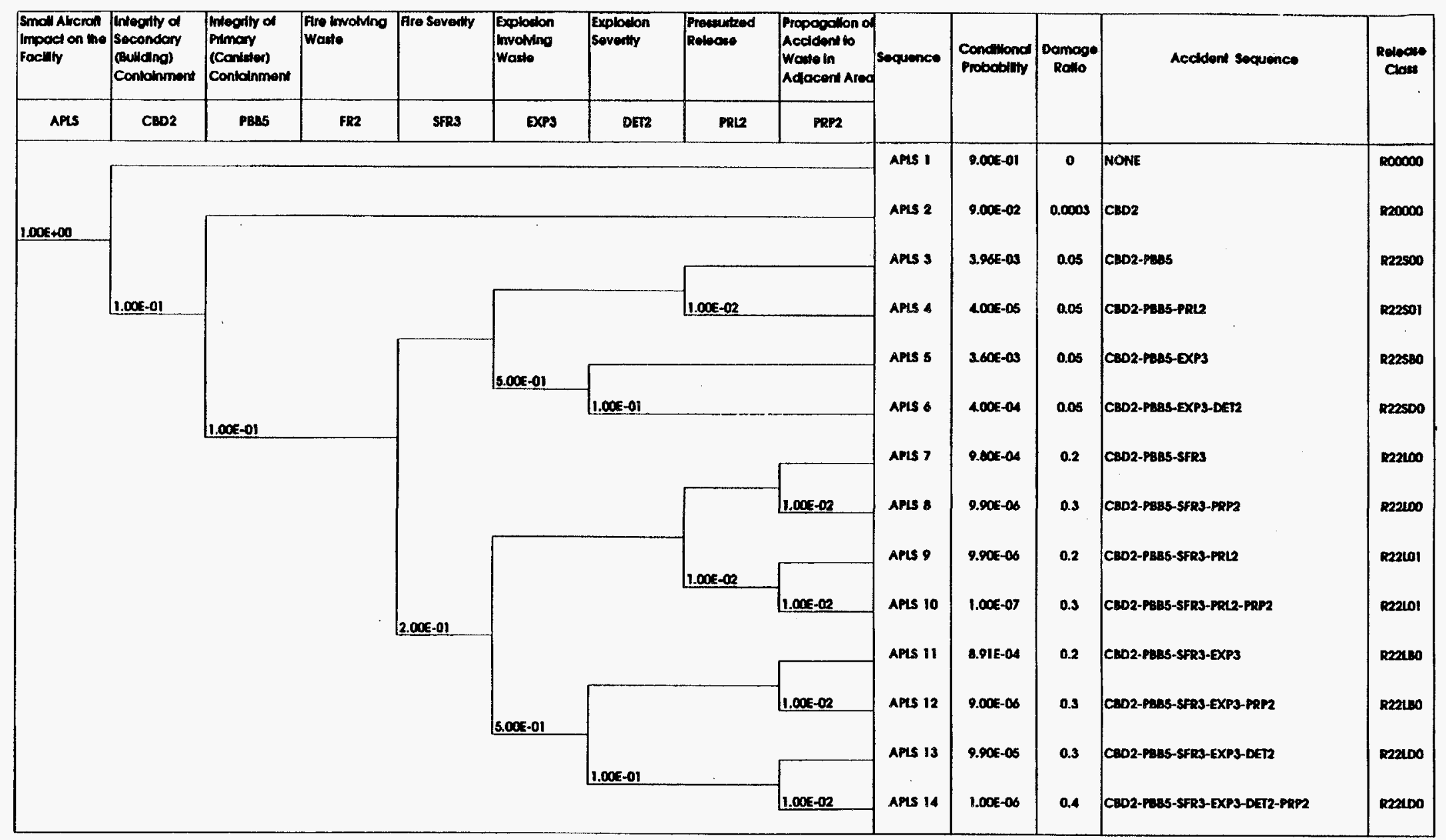

FIGURE G.4 Event Tree for Small-Aircraft Impact on Generic DOE Hazard Category 2 Incineration Facility 


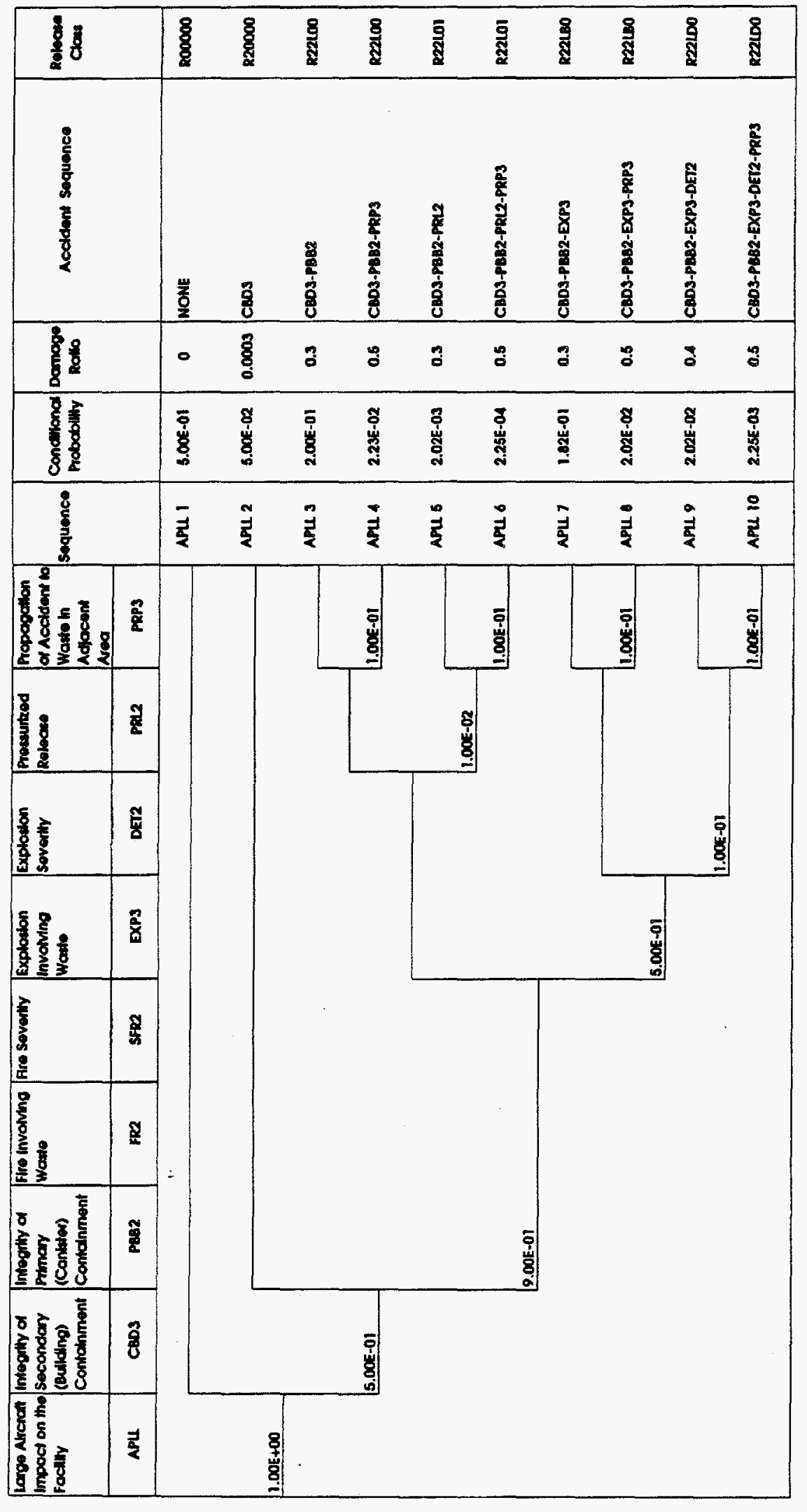

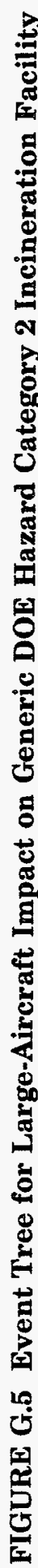




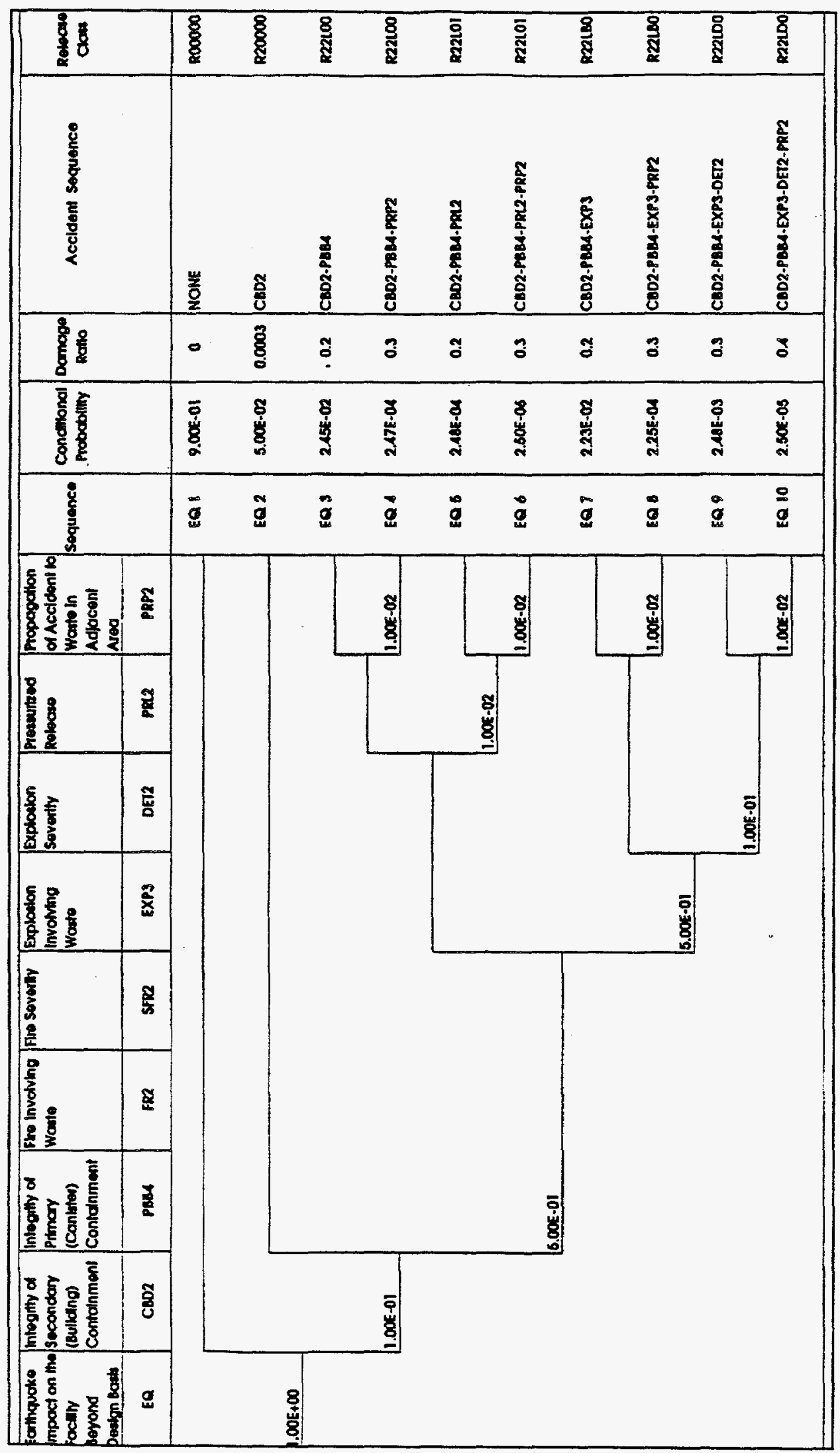

总 


\section{G.3.1.2 Integrity of Primary Containment (PDB)}

The major pieces of equipment (which form the primary containment) in this facility are the rotary kiln and the secondary combustion chamber. It has been assumed that these components will be designed to the same performance goals as the facility. Because the failure of the equipment is evaluated for the case of containment breach, as indicated by the event tree, the probability of equipment failure for the same seismic design goals, knowing that the containment building has failed, will be expected to be higher than the independent equipment failure probability. A value of 0.5 was used for the primary containment failure under seismic conditions; a probability of 0.1 was used for small-aircraft impacts; for large aircraft, a high probability of primary rupture (0.9) was used under the situation of a breached building.

\section{G.3.1.3 Occurrence of Fire (FR)}

All three types of initiating events were assumed to result in fires.

\section{G.3.1.4 Severity of Fire (SFR)}

The large aircraft and seismic initiating events were assumed to result in severe fires. For small aircraft, only one in five fires was assumed to be severe.

\section{G.3.1.5 Occurrence of Explosions Involving Waste (EXP)}

Little or no information exists on external events inducing explosions in an incineration facility; however, an accident involving explosion of a kiln or secondary combustion chamber (SCC) is considered possible in this type of facility. Incinerators were assumed to have fuel supplies to aid in the combustion of some waste. The same conditional probability (0.5) was assigned for all accident initiators and branches.

\section{G.3.1.6 Severity of Explosion (DET)}

The severity of the explosion refers to the differentiation between a deflagration and a detonation; the shock waves associated with detonation are capable of dispersing material beyond those of a deflagration. While no generic or facility-specific information exists to precisely quantify their relative frequencies, the likelihood of a detonation will be much smaller, given the absence of material associated with known detonations for all plausible initiators. Accordingly, the value of 0.1 was assigned as the conditional probability of a detonation, given that an explosion occurs. 


\section{G.3.1.7 Pressurized Release (PRL)}

The percentage of liquid waste in the incineration facility is likely to be smaller than the $10 \%$ assumed for some storage facilities, although some aqueous liquids occur as incineration residues from off-gas treatment. In the absence of specific information on facility designs, it was assumed that these liquid residues are collected and can be released in a pressurized manner. The probability is estimated as the same order of magnitude as for a release of LLMW in the presence of fire for storage facilities. The value of 0.01 applies for all initiators.

\section{G.3.1.8 Propagation to Next Area (PRP)}

The propagation event in the incineration facility represents the spread of the accident from the incineration rooms to the areas where the front-end storage or the off-gas and ash treatment take place. Propagation takes place only with a severe fire; the fire-suppression systems, fire brigades, and fire barriers must fail for the propagation to take place. The combined failure probability of all of these actions or systems would be expected to be on the order of the facility's performance goal (1.0E-04) or lower if one considered their failure to be independent. However, under external accident conditions, the failure probability must be higher because of the assumed loss of integrity for the facility. The combined failure probability was assumed to be 0.01 for natural phenomena and small-aircraft impacts and 0.1 for large-aircraft impacts.

\section{G.3.2 Evaluation of Source Term Parameters for Treatment Facilities}

Information on incineration facilities (i.e., the consolidated Incineration Facility [CIF] [DuPont 1987], a conceptual facility [Feizollahi and Shropshire 1992c], and the Waste Experimental Reduction Facility [WERF] [EG\&G 1992]) was reviewed; each document provided part of the required data for the accident analysis. As discussed in Section 2.5 of this report, the incineration facilities considered here have the following general areas: the receiving, storage, and feed area; the rotary kiln; the off-gas SCC; the off-gas treatment area; the liquid treatment area; the solidification area; and the high-efficiency particulate air (HEPA) filtration systems. The receiving, storage, and feed area contains waste in various (but mostly solid) physical forms. The liquid treatment area contains the liquid residue generated in the incineration process. The solidification system consists of mixing the ash resulting from the incineration with a solidification agent, such as concrete, for immobilization. Radioactive waste in the other areas is in the form of ash. Although wet ash is found in all CIF ash areas except the two combustion chambers, dry ashes are apparently found in the other facilities and are assumed for source term development here.

To simplify the source term evaluation for radioactive waste, the ash in the facility was used to derive ratio estimates for the MAR, DF, and RARF. The material in the storage area and in the liquid and solidification treatment areas was considered for chemical waste (LLMW and HW), but can be neglected for radiological releases because incineration ashes 
are in the most dispersible (i.e., particulate) form and also contain the highest concentration of radionuclides. The storage area, which tends to be separated from the rest of the facility, contains only a small number of drums compared with the on-site storage facilities. The MAR in the liquid streams (of small volume) and solidified product is expected to be in a significantly less releasable form than the ash.

The radiological MAR (i.e., the ash) is located in four major areas in the facility: primary incinerator (kiln and ash-out zone); SCC; off-gas treatment areas; and HEPA filtration system area. The total amount of ash in the facility will, in general, be a function of the process rate of the facility, depending on the DOE site and EM PEIS alternative. The only information relating the process rate to the ash inventory is provided in the CIF documentation (DuPont 1987). The average process rate for LLW solids in the facility is about $330 \mathrm{~kg} / \mathrm{h}(720 \mathrm{lb} / \mathrm{h}$ ), and the total (solids and liquids) averages about $450 \mathrm{~kg} / \mathrm{h}$ $(1,000 \mathrm{lb} / \mathrm{h})$. The total amount of ash in the CIF facility is about $1,600 \mathrm{~kg}(3,500 \mathrm{lb})$, excluding the ashcrete (solidified form) and particulates in the liquid storage tanks.

To determine the locations of the MAR, information from the CIF and other incineration facilities in the design phase was used. The approximate average distribution of the incinerator ash in the generic facility is as shown in Table G.1.

For radiological releases, the DFs were estimated as follows. For all accident sequences with only mechanical breach of the secondary confinement (but no breach of primary confinement), it was assumed that flow disturbances affect only the filtration system and that $1 \%$ of the material in the filters is spilled, for a DF (of the total facility ash inventory) of 3.0E-04. In sequences involving small fires (small-aircraft crashes only), the area containing the highest fraction (0.49) of ashes (i.e., the off-gas treatment area) was

TABLE G.1 Approximate Distribution of Incinerator Ash in the Generic Facility

\begin{tabular}{|c|c|}
\hline Location & $\begin{array}{c}\text { Fraction of Total } \\
\text { Ash Inventory of } \\
\text { Facility }\end{array}$ \\
\hline Kiln & 0.12 \\
\hline Ash-out area & 0.36 \\
\hline $\begin{array}{l}\text { Total of kiln and ash-out } \\
\text { area }\end{array}$ & 0.48 \\
\hline SCC & 0.12 \\
\hline Off-gas treatment area & 0.37 \\
\hline $\begin{array}{l}\text { Total of SCC and off-gas } \\
\text { treatment area }\end{array}$ & 0.49 \\
\hline HEPA filtration system & 0.03 \\
\hline $\begin{array}{l}\text { Total of HEPA } \\
\text { filtration system }\end{array}$ & 0.03 \\
\hline
\end{tabular}


assumed to be affected. Because Hazard Category 2 facilities are expected to have fire-suppression systems, $10 \%$ of the material in this area was assumed to be involved, resulting in a DF of 0.05 . Small-fire sequences involving explosions or pressurized releases were also assumed to be bounded by a DF of 0.05 .

Severe fires for all sequences have been assumed to start in the rotary kiln area because of the presence of fuel. For natural phenomena and small-aircraft crashes, the severe fire is generally confined to this area, with low-probability propagation sequences accounting for the fire spreading to the off-gas treatment area. The DFs were estimated by assuming that $50 \%$ of the material in the kiln area (48\% of the facility ash inventory) is affected, for a DF of 0.24 . In fire-propagation sequences, $50 \%$ of the material in the SCC (12\% of facility ash) and $10 \%$ of the material in the off-gas treatment equipment (10\% of facility ash) was added to the damaged material, for an estimated DF of 0.34 . For sequences involving detonation explosions, the ash in the HEPA filters ( $3 \%$ facility ash) was added, resulting in analogous DFs of 0.27 and 0.37 .

For large-aircraft impacts, the initial severe fire (fed with additional fuel) was assumed to engulf the kiln and off-gas treatment areas and to involve $50 \%$ of the material in the kiln area and the SCC and $10 \%$ of the off-gas treatment equipment ash contents (DF of 0.34). With propagation, up to $50 \%$ of the off-gas treatment material will be involved, with a total DF of 0.48. For explosion sequences involving detonations, the ash in the HEPA filters was added, resulting in analogous DFs of 0.37 and 0.51 .

For chemical source terms, the material in the feedstock area was assumed to be involved. On the basis of information from commercial incineration facilities, it was assumed that there would be three times the daily processing rate for the MAR. A DF of 0.2 has been assigned for seismic events and small-aircraft impacts and a DF of 0.3 for large-aircraft impacts.

\section{G.4 REFERENCES}

EG\&G, 1990, Safety Analysis Report for the Hazardous Waste Storage Facility, EG\&G-WM-PD-88-014, rev. 1, EG\&G Idaho, Inc., Idaho Falls, Idaho, Nov.

EG\&G, 1992, Draft Environmental Assessment: Idaho National Laboratory Low-Level and Mixed Waste Processing, DOE/EA-XXXX, EG\&G Idaho, Inc., Idaho Falls, Idaho, Dec.

E.I. Du Pont de Nemours \& Co., 1987, Safety Assessment Document: Consolidated Incineration Facility, approved draft, DPSTAD-200-6, Savannah River Laboratory, Aiken, S.C., Oct.

Feizollahi, F., and D. Shropshire, 1992, Waste Management Facilities Cost Information (WMFCI) Report, EGG-WID-10433, draft, EG\&G Idaho, Inc., Idaho Falls, Idaho.

Kennedy, R.P., et. al., 1990, Design and Evaluation Guidelines for Department of Energy Facilities Subjected to Natural Phenomena Hazards, UCRL-15910, Lawrence Livermore National Laboratory, Livermore, Calif. 


\section{APPENDIX H:}

REFERENCE DATA ON AIRBORNE RELEASES FOR ACCIDENTS INVOLVING HAZARDOUS CHEMICALS 


\section{CONTENTS}

NOTATION

H.1 INTRODUCTION $\ldots \ldots \ldots \ldots \ldots \ldots \ldots \ldots \ldots \ldots \ldots \ldots \ldots \ldots \ldots \ldots \ldots$ H-7

H.2 HANDLING ACCIDENT IN WHICH AQUEOUS AMMONIA

H.3 HANDLING ACCIDENT IN WHICH HYDROCHLORIC ACID IS SPILLED

H.4 HANDLING ACCIDENT IN WHICH AQUEOUS HYDROGEN FLUORIDE IS SPILLED

H.5 HANDLING ACCIDENT IN WHICH NITRIC ACID IS SPILLED

H.6 HANDLING ACCIDENT IN WHICH AN AROMATIC HYDROCARBON SPILLS AND BURNS

H.7 HANDLING ACCIDENT IN WHICH A FLAMMABLE LIQUID SPILLS, IGNITES, AND BURNS, CAUSING THE RUPTURE OF OTHER CONTAINERS

H.8 HANDLING ACCIDENT IN WHICH A FLAMMABLE LIQUID SPILLS AND IGNITES; THE FIRE ENGULFS NEARBY DRUMS AND INITIATES REACTIONS THAT RELEASE HIGHLY TOXIC VAPORS

H.9 LARGER ACCIDENT IN WHICH A FLAMMABLE LIQUID SPILLS AND IGNITES; THE FIRE ENGULFS NEARBY DRUMS AND INITIATES REACTIONS THAT RELEASE TOXIC VAPORS

H.10 HEAT FROM THE FIRE CAUSES AN EXPLOSION IN A COMPRESSED GAS CONTAINER, RESULTING IN VENTING OF A TOXIC GAS

H.11 ACCIDENTAL CO-CONFINEMENT OF OXIDIZING AND REDUCING AGENTS, LEADING TO A REACTION GENERATING HEAT THAT IGNITES PACKAGING AND BREACHES A NEARBY DRUM

H.12 ACCIDENTAL CONFINEMENT OF WATER WITH ALKALI METALS, ALKALI-METAL HYDRIDES, OR ALKALINE-EARTH OXIDES, GIVING REACTIONS GENERATING HEAT, IGNITING PACKAGING, AND BREACHING NEARBY DRUMS

H.13 ACCIDENTAL RUPTURE OF COMPRESSED GAS DUE TO VALVE FAILURE, RESULTING IN RELEASES OF TOXIC GAS 
H.14 EXPLOSION OF A STORED CHEMICAL $\ldots \ldots \ldots \ldots \ldots \ldots \ldots \ldots$ H-16

H.15 HANDLING ACCIDENTS IN WHICH A SPILLED WASTE RELEASES A MUTAGENIC, TERATOGENIC, OR CARCINOGENIC SUBSTANCE

H.16 HANDLING ACCIDENT SPILL THAT IGNITES FLAMMABLE LIQUIDS, THEREBY BREACHING NEARBY DRUMS WITH CADMIUM-CONTAINING COMPOUNDS

H.17 HANDLING ACCIDENT SPILL THAT IGNITES FLAMMABLE LIQUID; THE FIRE BREACHES NEARBY DRUMS CONTAINING DICHROMATE SALTS 


\section{NOTATION}

The following is a list of acronyms, initialisms, and abbreviations (including units of measure) used in this appendix.

\section{ACRONYMS, INITIALISMS, AND ABBREVIATIONS}

$a q$

$\mathrm{C}_{2} \mathrm{H}_{5}-\mathrm{O}-\mathrm{C}_{2} \mathrm{H}_{5}$

$\mathrm{C}_{3} \mathrm{H}_{6} \mathrm{O}$

$\mathrm{C}_{6} \mathrm{H}_{10} \mathrm{O}_{5}$

$\mathrm{C}_{6} \mathrm{H}_{6}$

$\mathrm{C}_{8} \mathrm{H}_{18}$

$\mathrm{Ca}(\mathrm{ClO})_{2}$

$\mathrm{Ca}(\mathrm{OH})_{2}$

$\mathrm{C}_{20} \mathrm{H}_{12}$

$\mathrm{CaO}$

Cd

$\mathrm{CH}_{3} \mathrm{COOH}$

$\mathrm{Cl}_{3} \mathrm{C}-\mathrm{CH}_{3}$

$\mathrm{CO}_{2}$

$\mathrm{Cs}$

$\mathrm{CS}_{2}$

DOE

$g$

$\mathrm{H}_{2}$

$\mathrm{H}_{2} \mathrm{O}$

$\mathrm{H}_{2} \mathrm{SO}_{4}$

$\mathrm{HBr}$

$\mathrm{HCl}(a q)$

$\mathrm{HCl}(g)$

HCN

$\mathrm{HF}$

$\mathrm{Hg}$

HI

$\mathrm{HNO}_{3}$

HWSF

$\mathrm{K}$

$\mathrm{K}_{2} \mathrm{Cr}_{2} \mathrm{O}_{7}$

$\mathrm{K}_{2} \mathrm{O}$

$\mathrm{KCN}$

$\mathrm{KMnO}_{4}$

$\mathrm{KOH}$

$l$

$\mathrm{Li}$

$\mathrm{MH}$

$\mathrm{MOnO}_{2}$ aqueous

diethyl ether

acetone

cellulose monomer unit

benzene

octane

calcium hypochlorite

calcium hydroxide

benzo[a]pyrene

quicklime

cadmium

glacial acetic acid

1,1,1-trichloroethane

carbon dioxide

cesium

carbon disulfide

U.S. Department of Energy

gas

hydrogen

water

sulfuric acid

hydrobromic acid

hydrochloric acid

hydrogen chloride

hydrogen cyanide

hydrofluoric acid

mercury

hydroiodic acid

nitric acid

hazardous waste storage facility

potassium

potassium dichromate

potassium oxide

potassium cyanide

potassium permanganate

potassium hydroxide

liquid

lithium

metal hydride

manganese (IV) oxide 


$\mathrm{N}_{2}$
$\mathrm{~N}_{2} \mathrm{O}$
$\mathrm{Na}$
$\mathrm{Na}_{2} \mathrm{SO}_{4}$
$\mathrm{NaCn}$
$\mathrm{NH}_{3}(a q)$
$\mathrm{NH}_{3}(g)$
$\mathrm{NH}_{4}$
$\mathrm{NO}$
$\mathrm{NO}_{2}$
$\mathrm{NO}_{\mathrm{x}}$
$\mathrm{PAH}$
$\mathrm{Rb}^{\mathrm{RCA}}$
$\mathrm{RCRA}$
$s$
$\Delta \mathrm{H}^{\circ}$

$\mathrm{N}_{2}$

$\mathrm{Na}$

$\mathrm{Na}_{2} \mathrm{SO}_{4}$

$\mathrm{NaCn}$

$\mathrm{NH}_{3}(a q)$

$\mathrm{NH}_{3}(g)$

$\mathrm{NH}_{4}$

$\mathrm{NO}$

$\mathrm{NO}_{\mathbf{x}}$

PAF

RCRA

$\Delta \mathrm{H}^{\circ}$ nitrogen

nitrous oxide

sodium

sodium sulfate

sodium cyanide

ammonia - in water

ammonia - gas

ammonium ion

nitric oxide

nitrogen dioxide

mixed oxides of nitrogen

polycyclic aromatic hydrocarbon

rubidium

Resource Conservation and Recovery Act

solid

standard change in enthalpy

\section{UNITS OF MEASURE}

$\begin{array}{ll}\text { atm } & \text { atmosphere(s) } \\ \text { bp } & \text { boiling point } \\ { }^{\circ} \mathrm{C} & \text { degree(s) Celsius } \\ { }^{\circ} \mathrm{F} & \operatorname{degree}(\mathbf{s}) \text { Fahrenheit } \\ \mathrm{g} & \operatorname{gram}(\mathbf{s}) \\ \mathrm{kJ} & \operatorname{kilojoule}(\mathbf{s}) \\ \mathrm{mol} & \operatorname{mole}(\mathbf{s})\end{array}$




\section{APPENDIX H:}

\section{REFERENCE DATA ON AIRBORNE RELEASES FOR ACCIDENTS INVOLVING HAZARDOUS CHEMICALS}

\section{H.1 INTRODUCTION}

All accidents were divided into three general categories, each having subcategories and including potentials for any adverse effects and potential life-threatening endpoints:

1. Spills resulting in partial vaporization of the waste ("spill only");

2. Spills followed by ignition of the waste ("spill plus fire"); and

3. "Other event combinations"

- spills followed by ignition of the waste and an induced explosion in a waste container ("spill plus fire plus explosion"),

- facility fires resulting in a waste container breach ("fire only"),

- mechanical failure of a compressed gas container resulting in an explosion ("spill and explosion"),

- explosion from exposure of reactive material to air followed by fire ("fire and explosion").

Table 8.4 in Volume 1 of this report lists the representative accidents chosen to serve as surrogates for all risk dominant sequences. The first 13 accidents involve the release of potentially life-threatening toxic gases; the remaining accidents involve the release of gas with only carcinogenic or sublethal impacts. In the development of these accidents, the following considerations were taken into account:

1. Proximity of classes of chemicals to each other in the storage facilities;

2. Typical designs of the storage facilities and the required separation of such groups of chemicals as flammable liquids, acids, caustics, combustibles, oxidizers, etc;

3. Ninety-day residence limit for Resource Conservation and Recovery Act (RCRA) hazardous waste in a storage facility.

The accident scenarios include a range of high-probability, low-consequence accidents and high-consequence, low-probability accidents. In general, these accidents involve chemical or physical changes in stored materials subsequent to an initial incident. Equations were derived to represent the changes anticipated to occur during the accidents. Toxic gaseous products were identified, and their masses estimated from the mass of the reactants and the stoichiometry of the reactions. Rates of releases were estimated on the basis of engineering judgment and the recognition that such rates often decay exponentially with time. Obviously, 
the exact course of an accident is shaped by a multitude of factors, including (but not limited to) temperature, humidity, pooling versus spreading of spills, the exact composition/concentration of reactive materials, (often unknown), and the proximity and nature of nearby reactive materials (including packaging, shelving, and flooring).

This appendix provides details on the selection of the accident scenarios, on the chemistry involved in their progression, and on the estimation of the rates of release of the toxic gases.

\section{H.2 HANDLING ACCIDENT IN WHICH AQUEOUS AMMONIA IS SPILLED}

This scenario was developed because large amounts of aqueous ammonia pass through U.S. Department of Energy (DOE) storage facilities and because of the well-known hazards of exposure to ammonia $\left(\mathrm{NH}_{3}\right)$.

Ammonia, a gas at ordinary conditions, is quite soluble in water. Chemically, it is a base. Solutions of ammonia in water $\left(\mathrm{NH}_{3}[a q]\right)$ are often called ammonium hydroxide (formula $\mathrm{NH}_{4} \mathrm{OH}$ ). Solutions of aqueous ammonia vary in concentration. Standard "concentrated ammonium hydroxide," which is widely distributed and used, consists of $28 \%$ $\mathrm{NH}_{3}$ by mass. Although it is probable that most waste ammonia is at least partly neutralized before disposal (by reaction with an acid in use), the scenario makes the conservative assumption that concentrated aqueous ammonia is spilled.

Concentrated aqueous ammonia evaporates and releases gaseous ammonia $\left(\mathrm{NH}_{3}[g]\right)$ according to the following equation:

$$
\begin{gathered}
\mathrm{NH}_{3}(a q) \rightarrow \mathrm{NH}_{3}(g) \quad \Delta \mathrm{H}^{\circ}=+34.18 \mathrm{~kJ} / \mathrm{mol} \\
\Delta \mathrm{H}^{\circ}=+2.0 \mathrm{~kJ} / \mathrm{g} \mathrm{NH} \mathrm{NH}_{3},
\end{gathered}
$$

which is equivalent to

$$
\mathrm{NH}_{4}^{+}(a q)+\mathrm{OH}^{-}(a q) \rightarrow \mathrm{NH}_{3}(g)+\mathrm{H}_{2} \mathrm{O}(l)
$$

Essentially all of the ammonia evaporates before the evaporation of any of the solvent water. Ammonia is far more volatile than water (the vapor pressure of $\mathrm{NH}_{3}$ at $25^{\circ} \mathrm{C}\left[77^{\circ} \mathrm{F}\right]$ is 10 atm, whereas that of water is $0.030 \mathrm{~atm}$ ).

The quantity to the right of Equation $\mathrm{H} .1$ is the standard change in enthalpy $\left(\Delta \mathrm{H}^{\circ}\right)$ for the process. A positive $\Delta \mathrm{H}^{\circ}$ means that the reaction is endothermic (withdraws heat from the surroundings); a negative $\Delta \mathrm{H}^{\circ}$ means that it is exothermic (generates heat in the surroundings). The $\Delta \mathrm{H}^{\circ}$ is given per mol of reaction as written and, in the second line, per gram of reactant. Thus, $1 \mathrm{~mol}$ of aqueous ammonia in its standard state takes up $34.18 \mathrm{~kJ}$ of energy to yield $1 \mathrm{~mol}$ of gaseous ammonia under standard conditions. Because evaporation is endothermic, the scenario envisages an early, more rapid release of $\mathrm{NH}_{3}(g)$ as spilled $\mathrm{NH}_{3}(a q)$ spreads out and is maintained at ambient temperature by contact with fresh warm surfaces. This is succeeded by a falling rate of release as the spill puddles and experiences local evaporative cooling. The times proposed for the two phases of the release of the toxic 
gas are reasonable estimates; actual times would range quite widely depending on the evolution, size, and shape of the evaporating surface of the spill. The proposed rates of evaporation of the ammonia are also reasonable estimates. Rates would depend strongly on the ambient temperature. An exponential decay in the rate of release is assumed to set in as the spill attains its full extent, as the exposed $\mathrm{NH}_{3}(a q)$ reaches a steady-state temperature, and as the solution dwindles in concentration.

The generation of gaseous ammonia is greatly accelerated if a spill encounters another base (e.g., lime or sodium hydroxide). Such compounds supply $\mathrm{OH}^{-}$ion to drive the evaporation strongly to the right.

$$
\mathrm{NH}_{4}^{+}(a q)+\mathrm{OH}^{-}(a q) \rightarrow \mathrm{NH}_{3}(g)+\mathrm{H}_{2} \mathrm{O}(l)
$$

Plans for the segregation of reactive materials in hazardous waste storage facilities (HWSFs) put acids and bases far apart, whereas weak volatile bases and strong bases are in close proximity.

The release of gaseous ammonia is representative of releases of amines, a numerous and important class of compounds. Amines are organic derivatives of ammonia that vary in toxicity and volatility. The release of amines from aqueous solution is also accelerated by contact with a strong base.

\section{H.3 HANDLING ACCIDENT IN WHICH HYDROCHLORIC ACID IS SPILLED}

This scenario is a chemical reversal (acid rather than base) of the ammonia spill just described. Hydrogen chloride $(\mathrm{HCl})$ is gaseous at room conditions but dissolves readily in water to yield hydrochloric acid (HCI $[a q]$, sometimes called muriatic acid). Hydrochloric acid is commonly shipped as a 12.1 molar solution (concentrated hydrochloric acid). This mixture contains $37 \% \mathrm{HCl}$ by mass. Aqueous solutions of $\mathrm{HCl}$ evaporate when not confined. Because $\mathrm{HCl}$ is more volatile than water, it predominates in the first vapors emitted:

$$
\begin{gathered}
\mathrm{H}^{+}(a q)+\mathrm{Cl}^{-}(a q) \rightarrow \mathrm{HCl}(\mathrm{g}) \underset{\Delta \mathrm{H}^{\circ}=+74.85 \mathrm{~kJ} / \mathrm{mol}}{\Delta \mathrm{H}^{\circ}=2.1 \mathrm{~kJ} / \mathrm{g} \mathrm{HCl} .}
\end{gathered}
$$

The other details in this scenario were developed in the same way as those in the ammonia spill. A slower outflux of gas in the second stage of the $\mathrm{HCl}(a q)$ spill is assumed because $\Delta \mathrm{H}^{\circ}$ for the evaporation of $\mathrm{HCl}(a q)$ exceeds $\Delta \mathrm{H}^{\circ}$ for the evaporation of $\mathrm{NH}_{3}(a q)$.

Concentrated $\mathrm{HCl}(a q)$ reacts with many metals, including iron and steel, to generate gaseous hydrogen:

$$
\begin{gathered}
2 \mathrm{H}^{+}(a q)+\mathrm{Fe}(s) \rightarrow \mathrm{H}_{2}(g)+\mathrm{Fe}^{2+}(a q) \Delta \mathrm{H}^{\circ}=-89.1 \mathrm{~kJ} / \mathrm{mol} \\
\Delta \mathrm{H}^{\circ}=-1.22 \mathrm{~kJ} / \mathrm{g} \mathrm{HCl}
\end{gathered}
$$

This reaction is not a "spill alone" and was not considered in that category. 
Also, the generation of $\mathrm{HCl}(g)$ from $\mathrm{HCl}(a q)$ is greatly favored both thermodynamically and kinetically by contact of the hydrochloric acid with a strong nonvolatile acid (the best example is sulfuric acid $\left[\mathrm{H}_{2} \mathrm{SO}_{4}\right]$ ). Strong acid drives the evaporation reaction strongly to the right.

The scenario developed here is representative of accidental spills of all volatile acids (such as hydrobromic acid [HBr $(a q)]$, hydroiodic acid [HI $(a q)]$, and hydrofluoric acid $[\mathrm{HF}(a q)]$ ).

\section{H.4 HANDLING ACCIDENT IN WHICH AQUEOUS HYDROGEN FLUORIDE IS SPILLED}

This scenario was developed because $\mathrm{HF}(g)$ is much more toxic than $\mathrm{HCl}(g)$. Otherwise, it is similar to the $\mathrm{HCl}(a q)$ spill. The evaporation reaction is as follows:

$$
\begin{gathered}
\mathrm{HF}(a q) \rightarrow \mathrm{HF}(g) \quad \Delta \mathrm{H}^{\circ}=+49.0 \mathrm{~kJ} / \mathrm{mol} \\
\Delta \mathrm{H}^{\circ}=2.45 \mathrm{~kJ} / \mathrm{g} \mathrm{HF} .
\end{gathered}
$$

$\mathrm{HF}$ is a weak acid in aqueous solution; that is, ionization to $\mathrm{H}^{+}(a q)$ and $\mathrm{F}^{-}(a q)$ ions is only slight, whereas $\mathrm{HCl}$ and the other hydrohalic acids ( $\mathrm{HBr}$ and $\mathrm{HI}$ ) are strong acids (completely ionized). This fact is sometimes erroneously advanced as mitigating the hazards of $\mathrm{HF}(a q)$. In fact, it has little influence on the events projected in the scenario.

The above reaction, like the evaporation of $\mathrm{HCl}$, is driven to the right by the presence in the system of a strong nonvolatile acid (such as $\mathrm{H}_{2} \mathrm{SO}_{4}$ ).

\section{H.5 HANDLING ACCIDENT IN WHICH NITRIC ACID IS SPILLED}

This scenario is a case in which a noxious gaseous compound is generated by chemical action subsequent to a spill.

The nitric acid $\left(\mathrm{HNO}_{3}[a q]\right)$ is assumed to be commercial concentrated nitric acid (approx. 70\% by mass). Concentrated nitric acid has great power as an oxidizing agent. Spills of $\mathrm{HNO}_{3}(a q)$ would generate clouds of $\mathrm{NO}_{\mathbf{x}}$ (mixed oxides of nitrogen) containing a large proportion of brown nitrogen dioxide $\left(\mathrm{NO}_{2}\right)$ as the advancing spill would touch various more or less easily oxidized materials. Indeed, concentrated nitric acid is likely to cause ignitions of wood, excelsior, and other cellulose products, particularly when the cellulosic material is finely divided or porous. A typical reaction of concentrated nitric acid with a metal is as follows:

$$
\begin{gathered}
\mathrm{Fe}(s)+3 \mathrm{HNO}_{3}(a q)+3 \mathrm{H}^{+}(a q) \rightarrow \mathrm{Fe}^{3+}(a q)+3 \mathrm{NO}_{2}(g)+3 \mathrm{H}_{2} \mathrm{O}(l) \\
\Delta \mathrm{H}^{\circ}=-191.5 \mathrm{~kJ} / \mathrm{mol} \\
\Delta \mathrm{H}^{\circ}=-1.01 \mathrm{~kJ} / \mathrm{g} \mathrm{HNO}
\end{gathered}
$$


The chemistry of nitric acid oxidations is much more complex than this. For example, the reaction of nitric acid with iron also yields nitric oxide ( $\mathrm{NO}[g])$, nitrous oxide $\left(\mathrm{N}_{2} \mathrm{O}[g]\right)$, nitrogen $\left(\mathrm{N}_{2}[g]\right)$, hydrogen $\left(\mathrm{H}_{2}[g]\right)$, and ammonium ion $\left(\mathrm{NH}_{4}^{+}[a q]\right)$, depending on the exact temperature and concentration of the acid. The acid would react similarly with most of the many materials it might encounter during a spill.

The scenario assumes that all the nitrogen in the $\mathrm{HNO}_{3}$ goes off as brown gaseous $\mathrm{NO}_{2}$. This amounts to $46 / 63$ (the ratio of the molar mass of $\mathrm{NO}_{2}$ to that of $\mathrm{HNO}_{3}$ ) of the mass of the $\mathrm{HNO}_{3}$, which is about $3 / 4$ of that mass. The scenario takes the mass of $\mathrm{NO}_{2}(g)$ as simply equal to the mass of $\mathrm{HNO}_{3}$ in the spill.

The pattern for the rate of release of the $\mathrm{NO}_{2}$ in this scenario purposely resembles that chosen in the three previous scenarios: strong at the start then dying down exponentially over time.

\section{H.6 HANDLING ACCIDENT IN WHICH AN AROMATIC HYDROCARBON SPILLS AND BURNS}

This scenario posits a fire in aromatic hydrocarbon wastes because such wastes are common in the HWSFs.

Aromatic hydrocarbons include benzene $\left(\mathrm{C}_{6} \mathrm{H}_{6}\right)$ and its derivatives (such as toluene and xylene). The complete combustion of benzene generates innocuous products and considerable heat:

$$
\begin{aligned}
& \mathrm{C}_{6} \mathrm{H}_{6}(l)+15 / 2 \mathrm{O}_{2}(g) \rightarrow 6 \mathrm{CO}_{2}(g)+3 \mathrm{H}_{2} \mathrm{O}(g) \quad \Delta \mathrm{H}^{\circ}=-3135 \mathrm{~kJ} / \mathrm{mol} \\
& \Delta \mathrm{H}^{\circ}=-40.2 \mathrm{~kJ} / \mathrm{g} \mathrm{C}_{6} \mathrm{H}_{6} \text {. }
\end{aligned}
$$

The combustion of benzene (or other aromatic hydrocarbons) in a puol in the open air does not proceed according to Equation H.8. Instead, oxidation is incomplete and produces quantities of carbon monoxide and soot. The soot is a mixture of elemental carbon and many compounds, including polycyclic aromatic hydrocarbons (PAHs) such as benzo[a]pyrene $\left(\mathrm{C}_{20} \mathrm{H}_{12}\right)$. Thus, a range of concurrent oxidation reactions takes place. Representative reactions include the following :

$$
\begin{gathered}
2 \mathrm{C}_{6} \mathrm{H}_{6}(l)+9 \mathrm{O}_{2}(g) \rightarrow 12 \mathrm{CO}(g)+6 \mathrm{H}_{2} \mathrm{O}(g) \\
2 \mathrm{C}_{6} \mathrm{H}_{6}(l)+3 \mathrm{O}_{2}(g) \rightarrow 12 \mathrm{C}(s)+6 \mathrm{H}_{2} \mathrm{O}(g) \\
10 \mathrm{C}_{6} \mathrm{H}_{6}(l)+6 \mathrm{O}_{2}(g) \rightarrow 3 \mathrm{C}_{20} \mathrm{H}_{12}(s)+12 \mathrm{H}_{2} \mathrm{O}(g)
\end{gathered}
$$

The molar ratio of oxygen to benzene decreases from $9 / 2$ to $6 / 10$ going down the list of three partial oxidations. All three reactions consume less oxygen than complete combustion, which uses oxygen in a $15 / 2$ molar ratio. 
The heat of combustion of the first portions of the hydrociarbon evaporates other portions as shown in the following equation.

$$
\mathrm{C}_{6} \mathrm{H}_{6}(l) \rightarrow \mathrm{C}_{6} \mathrm{H}_{6}(g) \quad \Delta \mathrm{H}^{\circ}=+33.9 \mathrm{~kJ} / \mathrm{mol}
$$

The unburned vapors present an inhalation hazard.

The total mass of the products of combustion of a quantity of a hydrocarbon exceeds that of the hydrocarbon by an amount equal to the mass of the oxygen that is taken up. A stoichiometric calculation shows that complete combustion (to $\mathrm{CO}_{2}$ and $\mathrm{H}_{2} \mathrm{O}$ ) of $m$ pounds of benzene requires $3.08 \mathrm{~m}$ pounds of oxygen. (Benzene has $78 \mathrm{~g} / \mathrm{mol}$ and oxygen has $32 \mathrm{~g} / \mathrm{mol}$. Thus, complete combustion of $2 \mathrm{~mol}$ of benzene by $15 \mathrm{~mol}$ of oxygen implies a mass ratio for the two reactants of $15 \times 32 / 2 \times 78$.) Incomplete combustion naturally uses less oxygen. The scenario assumes that $12 \%$ of the hydrocarbon is evaporated; $40 \%$ is converted to soot having approximately the same mass as the hydrocarbon reacted; and the rest is converted to water, carbon monoxide, and carbon dioxide. This distribution of products is representative but would vary greatly with the actual circumstances of the fire.

\section{H.7 HANDLING ACCIDENT IN WHICH A FLAMMABLE LIQUID SPILLS, IGNITES, AND BURNS, CAUSING THE RUPTURE OF OTHER CONTAINERS}

This scenario hinges on a contingent event. It points out that (1) oxygen is not the only oxidizing agent that might become involved in a fire in a HWSF and (2) an otherwise ordinary fire can be intensified by involvement of neighboring chemically active wastes.

Flammable organic solvents (e.g., acetone) are reducing agents that tend to react with oxidizing agents such as $\mathrm{Ca}(\mathrm{ClO})_{2}$ (calcium hypochlorite). For example,

$$
\begin{gathered}
\mathrm{C}_{3} \mathrm{H}_{6} \mathrm{O}(\mathrm{l})+4 \mathrm{Ca}(\mathrm{ClO})_{2} \rightarrow 4 \mathrm{CaCl}_{2}(s)+3 \mathrm{CO}_{2}(g)+3 \mathrm{H}_{2} \mathrm{O}(\mathrm{g}) \\
\Delta \mathrm{H}^{\circ}=-2159 \mathrm{~kJ} / \mathrm{mol} \\
\Delta \mathrm{H}^{\circ}=-37.2 \mathrm{~kJ} / \mathrm{g} \mathrm{C}_{3} \mathrm{H}_{6} \mathrm{O}
\end{gathered}
$$

The rate of generation of the heat would depend on the details of the contact between the reactants. However, involvement of stored oxidizing agents could aggravate an otherwise ordinary solvent fire in a HWSF, as shown by comparing the preceding $\Delta \mathrm{H}^{\circ}$ to the $\Delta \mathrm{H}^{\circ}$ for the simple combustion of a mol of acetone:

$$
\begin{gathered}
\mathrm{C}_{3} \mathrm{H}_{6} \mathrm{O}(l)+4 \mathrm{O}_{2}(g) \rightarrow 3 \mathrm{CO}_{2}(g)+3 \mathrm{H}_{2} \mathrm{O}(g) \Delta \mathrm{H}^{\circ}=-1689 \mathrm{~kJ} / \mathrm{mol} \\
\Delta \mathrm{H}^{\circ}=-29.1 \mathrm{~kJ} / \mathrm{g} \mathrm{C}_{3} \mathrm{H}_{6} \mathrm{O} .
\end{gathered}
$$

The reaction of acetone with $\mathrm{Ca}(\mathrm{ClO})_{2}$ could also proceed faster, leading to higher local temperatures.

In this scenario, it is suggested that the heat ruptures a nearby container of $\operatorname{HF}(a q)$, causing dispersal of $\mathrm{HF}(\mathrm{g})$ into the air (see above). The estimated rate of release in this puff 
is meant as a single intense spurt of HF when the container ruptures following strong heating.

\section{H.8 HANDLING ACCIDENT IN WHICH A FLAMMABLE LIQUID SPILLS AND IGNITES; THE FIRE ENGULFS NEARBY DRUMS AND INITIATES REACTIONS THAT RELEASE HIGHLY TOXIC VAPORS}

Like the previous scenario, this scenario hinges on contingent events. A solvent catches fire:

$$
\mathrm{C}_{3} \mathrm{H}_{6} \mathrm{O}(l)+4 \mathrm{O}_{2}(g) \rightarrow 3 \mathrm{CO}_{2}(g)+3 \mathrm{H}_{2} \mathrm{O}(g) \quad \Delta \mathrm{H}^{\circ}=-1689 \mathrm{~kJ}
$$

Heat from the fire is assumed to rupture nearby or engulfed containers. The released materials react among themselves (apart from the fire) to generate toxic gases. The simultaneous release of a waste acid (such as $\mathrm{H}_{2} \mathrm{SO}_{4}, \mathrm{HCl}$, or $\mathrm{HNO}_{3}$, which are common in the HWSFs) and a cyanide salt (such as sodium cyanide [NaCN] or potassium cyanide [KCN]) could then lead to the release of very toxic $\mathrm{HCN}(g)$ from the reaction:

$$
\mathrm{H}_{2} \mathrm{SO}_{4}(a q)+2 \mathrm{NaCN}(s, \text { or } a q) \rightarrow 2 \mathrm{HCN}(g)+\mathrm{Na}_{2} \mathrm{SO}_{4}(a q) \text {. }
$$

The preceding reaction is essentially instantaneous once the reactants are in contact. The scenario assumes that contact between the acid and the cyanide salt occurs rapidly. The yield of $\mathrm{HCN}(\mathrm{g})$ (assuming an excess of acid) would be 0.55 pounds per pound of $\mathrm{NaCN}$. For simplicity, the mass of the $\mathrm{HCN}(\mathrm{g})$ is assumed to equal the mass of the cyanide salt in the hazardous waste container.

\section{H.9 LARGER ACCIDENT IN WHICH A FLAMMABLE LIQUID SPILLS AND IGNITES; THE FIRE ENGULFS NEARBY DRUMS AND INITIATES REACTIONS THAT RELEASE TOXIC VAPORS}

The occasional presence of large quantities of flammables in HWSFs prompted the development of this scenario. A burning tank-car of naphtha (the $\mathrm{C}_{4}$ to $\mathrm{C}_{10}$ fraction from petroleum used to make gasoline) is a serious fire in any setting:

$$
\begin{aligned}
\mathrm{C}_{8} \mathrm{H}_{18}+25 / 2 \mathrm{O}_{2} \rightarrow & 8 \mathrm{CO}_{2}(\mathrm{~g})+9 \mathrm{H}_{2} \mathrm{O}(\mathrm{g}) \quad \Delta \mathrm{H}^{\circ}=-5450 \mathrm{~kJ} / \mathrm{mol} \\
& \Delta \mathrm{H}^{\circ}=-44.8 \mathrm{~kJ} / \mathrm{g} \mathrm{C}_{8} \mathrm{H}_{18} .
\end{aligned}
$$

In a HWSF, the fire might engulf stored oxidizing agents, which would intensify the fire. For example,

$$
\begin{gathered}
\mathrm{C}_{8} \mathrm{H}_{18}+25 / 2 \mathrm{Ca}(\mathrm{ClO})_{2} \rightarrow 25 / 2 \mathrm{CaCl}_{2}(s)+8 \mathrm{CO}_{2}(g)+9 \mathrm{H}_{2} \mathrm{O}(g) \\
\Delta \mathrm{H}^{\circ}=-6586 \mathrm{~kJ} / \mathrm{mol} \\
\Delta \mathrm{H}^{\circ}=-57.8 \mathrm{~kJ} / \mathrm{g} \mathrm{C}_{8} \mathrm{H}_{18} .
\end{gathered}
$$

Further, it might cause release of toxic vapors as in scenarios 7 and 8 . 
Such a fire could cause the release of toxic materials from objects generally thought to have a low hazard (such as mercury cells). A hot fire vaporizes mercury (bp $357^{\circ} \mathrm{C}$ $\left[675^{\circ} \mathrm{F}\right]$ ) easily according to the following equation:

$$
\mathrm{Hg}(l) \rightarrow \mathrm{Hg}(g) \quad \Delta \mathrm{H}^{\circ}=61.32 \mathrm{~kJ} / \mathrm{mol} .
$$

The release of $\mathrm{Hg}$ in such an event would be intermittent, as the cells ruptured.

\section{H.10 HEAT FROM THE FIRE CAUSES AN EXPLOSION IN A COMPRESSED GAS CONTAINER, RESULTING IN VENTING OF A TOXIC GAS}

This scenario is included because the inventories of the HWSFs include containers of pressurized gases or liquid/gas mixtures. Such systems are liable to rupture if heated.

The precipitating event here is the combustion of a spilled flammable liquid, as in preceding scenarios. This generates enough heat to cause explosive failure of a container of confined toxic gas. In this case, the gas is taken to be ammonia $\left(\mathrm{NH}_{3}[g]\right)$. The release of the contents in a single burst is a representative result in the catastrophic failure of pressurized gas containers.

\section{H.11 ACCIDENTAL CO-CONFINEMENT OF OXIDIZING AND REDUCING AGENTS, LEADING TO A REACTION GENERATING HEAT THAT IGNITES PACKAGING AND BREACHES A NEARBY DRUM}

This class of accidents hinges on the large amounts of heat released by many redox (oxidation-reduction) reactions. These accidents are considered separate from the ubiquitous case of combustion, in which the fuel is the reducing agent and oxygen (air) is the oxidizing agent The HWSF inventories include numerous oxidizing agents such as chlorates, perchlorates, persulfates, chromates and dichromates, and permanganates. Reducing agents are also found in the inventories and in packing and other everyday materials as well. Wood, paper, paint, film, and plastics can all serve as reducing agents. A possible reaction would be the following:

$$
8 \mathrm{KMnO}_{4}+\left(\mathrm{C}_{6} \mathrm{H}_{10} \mathrm{O}_{5}\right) \rightarrow 6 \mathrm{CO}_{2}+5 \mathrm{H}_{2} \mathrm{O}+4 \mathrm{~K}_{2} \mathrm{O}+8 \mathrm{MnO}_{2},
$$

where $\mathrm{C}_{6} \mathrm{H}_{10} \mathrm{O}_{5}$ is the cellulose monomer unit.

A chemical reaction does not occur automatically on contact between a good reducing agent and good oxidizing agent. For example, newspaper (a reducing agent) lasts more or less indefinitely in air. Still, some redox reactions are immediate upon mixing the reactants; others can set in and occur rapidly after a long induction period.

In this scenario, a case is visualized in which commingled oxidizing and reducing agents ultimately react and generate either enough heat to start a fire or cause rupture of 
a nearby container holding pressurized toxic gas. It is assumed that the toxic gas is released in a single burst upon decompression.

\section{H.12 ACCIDENTAL CONFINEMENT OF WATER WITH ALKALI METALS, ALKALI-METAL HYDRIDES, OR ALKALINE-EARTH OXIDES, GIVING REACTIONS GENERATING HEAT, IGNITING PACKAGING, AND BREACHING NEARBY DRUMS}

Part of this scenario (the reaction of water with alkali metals and alkali-metal hydrides) is a special case of the previous redox scenario; it is distinguished from the redox scenario by the particularly violent and rapid nature of the reactions. The last part (reaction of water with alkaline-earth oxides) is included because of the strong generation of heat from an acid-base reaction.

The alkali metals (lithium [Li], sodium [Na], potassium [K], rubidium [Rb], and cesium [Cs]) all react rapidly with water to generate gaseous hydrogen and a hydroxide:

$$
\begin{aligned}
& 2 \mathrm{M}(s)+2 \mathrm{H}_{2} \mathrm{O}(l) \rightarrow \mathrm{H}_{2}(g)+2 \mathrm{M}^{+}(a q)+2 \mathrm{OH}^{-}(a q) \\
& \Delta \mathrm{H}^{\circ} \mathrm{s} \text { approx }-650 \mathrm{~kJ} / \mathrm{mol} \text {. }
\end{aligned}
$$

The heat of the reaction melts the metal and usually ignites the hydrogen, which burns rapidly:

$$
2 \mathrm{H}_{2}(g)+\mathrm{O}_{2}(g) \rightarrow 2 \mathrm{H}_{2} \mathrm{O}(g) \quad \Delta \mathrm{H}^{\circ}=-241.8 \mathrm{~kJ} / \mathrm{mol} \text {. }
$$

Any combustible materials would become involved in the fire and the fire would spread.

The alkali metal hydrides ( $\mathrm{MH}$ ) (such as $\mathrm{LiH}, \mathrm{NaH}, \mathrm{RbH}$ ) are also violently oxidized by water:

$$
\begin{gathered}
\mathrm{MH}(s)+\mathrm{H}_{2} \mathrm{O}(l) \rightarrow 1 / 2 \mathrm{H}_{2}(g)+\mathrm{M}^{+}(a q)+\mathrm{OH}^{-}(a q) \\
\Delta \mathrm{H}^{\circ} \mathrm{s} \text { approx }-140 \mathrm{~kJ} / \mathrm{mol}
\end{gathered}
$$

This heat of this reaction also often ignites the hydrogen produced.

The reactions of alkali-metal oxides or alkali-earth oxides with water are acid-base reactions (not oxidation-reduction reactions). Typical equations are as follows:

$$
\begin{aligned}
& \mathrm{K}_{2} \mathrm{O}(s)+\mathrm{H}_{2} \mathrm{O}(l) \rightarrow 2 \mathrm{KOH}(a q) \quad \Delta \mathrm{H}^{\circ}=-361.4 \mathrm{~kJ} / \mathrm{mol} \\
& \Delta \mathrm{H}^{\circ}=-3.85 \mathrm{~kJ} / \mathrm{g} \mathrm{K} \mathrm{O} \\
& \mathrm{CaO}(s)+\mathrm{H}_{2} \mathrm{O}(l) \rightarrow 2 \mathrm{Ca}(\mathrm{OH})_{2}(s) \Delta \mathrm{H}^{\circ}=-1052 \mathrm{~kJ} / \mathrm{mol} \\
& \Delta \mathrm{H}^{\circ}=-18.8 \mathrm{~kJ} / \mathrm{g} \mathrm{CaO} \text {. }
\end{aligned}
$$

The heat is generated rapidly enough to ignite paper, wood, or other packing materials. The accidental wetting of paper bags of quicklime ( $\mathrm{CaO}$ ' has caused numerous fires. 


\section{H.13 ACCIDENTAL RUPTURE OF COMPRESSED GAS (NOS [NOT OTHERWISE SPECIFIED] FLAMMABLE) DUE TO VALVE FAILURE, RESULTING IN RELEASES OF TOXIC GAS}

This scenario treats a simple failure of confinement of a pressurized gas. The consequences would depend on the identity of the gas, which is often not known ("NOS"). It is assumed here that the toxic gas is ammonia.

The release of compressed gas would be complete essentially immediate; this is not the same as the evaporative release of a dissolved gas from a liquid spill.

\section{H.14 EXPLOSION (WITHOUT PREVIOUS SPILL) OF A STORED CHEMICAL}

This scenario highlights the fact that certain stored chemicals can explode without obvious initiation. The formation of explosive peroxides from ethers in contact with air is well-known.

$$
\mathrm{C}_{2} \mathrm{H}_{5}-\mathrm{O}-\mathrm{C}_{2} \mathrm{H}_{5}+1 / 2 \mathrm{O}_{2} \rightarrow \mathrm{C}_{2} \mathrm{H}_{5}-\mathrm{O} \cdot \mathrm{O}-\mathrm{C}_{2} \mathrm{H}_{5}
$$

Such explosions can occur without apparent prompting. The scenario envisages such an event with the following sequelae: (1) a quick fire in the unperoxidized ether and (2) the rupture of a nearby container of a toxic gas (assumed for the sake of illustration to be ammonia). The release of compressed gas would be complete essentially immediate; this is not the same as the evaporative release of a dissolved gas from a liquid spill.

\section{H.15 HANDLING ACCIDENTS IN WHICH A SPILLED WASTE RELEASES A MUTAGENIC, TERATOGENIC, OR CARCINOGENIC SUBSTANCE}

Glacial (pure) acetic acid spills and subsequently evaporates as follows:

$$
\begin{gathered}
\mathrm{CH}_{3} \mathrm{COOH}(l) \rightarrow \mathrm{CH}_{3} \mathrm{COOH}(\mathrm{g}) \quad \Delta \mathrm{H}^{\circ}=+52.25 \mathrm{~kJ} / \mathrm{mol} \\
\Delta \mathrm{H}^{\circ}=+0.87 \mathrm{~kJ} / \mathrm{g} \text { acetic acid } .
\end{gathered}
$$

Slower rates of release than in previous similar scenarios are proposed because acetic acid is less volatile (bp $118^{\circ} \mathrm{C}\left[244^{\circ} \mathrm{F}\right]$ ) than the other acids.

A similar spill of $\mathrm{CS}_{2}(l)$ (carbon disulfide), a nonacidic liquid, vaporizes as follows:

$$
\begin{gathered}
\mathrm{CS}_{2}(l) \rightarrow \mathrm{CS}_{2}(g) \quad \Delta \mathrm{H}^{\circ}=+27.66 \mathrm{~kJ} / \mathrm{mol} \\
\Delta \mathrm{H}^{\circ}=+0.69 \mathrm{~kJ} / \mathrm{gS}_{2}
\end{gathered}
$$

The release rate of the vapor is set somewhat higher than for acetic acid because $\mathrm{CS}_{2}$ is more volatile (bp $46.5^{\circ} \mathrm{C}$ ) . 
A spill of 1,1,1-trichloroethane $\left(\mathrm{Cl}_{3} \mathrm{CCH}_{3}\right)$, a volatile solvent, in a substantially larger amount evaporates as follows:

$$
\begin{gathered}
\mathrm{Cl}_{3} \mathrm{CCH}_{3}(l) \rightarrow \mathrm{Cl}_{3} \mathrm{CCH}_{3}(\mathrm{~g}) \quad \Delta \mathrm{H}^{\circ}=+32.8 \mathrm{~kJ} / \mathrm{mol} \\
\Delta \mathrm{H}^{\circ}=+0.25 \mathrm{~kJ} / \mathrm{g} \mathrm{Cl}_{3} \mathrm{CCH}_{3} .
\end{gathered}
$$

The boiling point of $1,1,1$-trichloroethane is $74^{\circ} \mathrm{C}\left(165^{\circ} \mathrm{F}\right)$. The rate of release as vapor would diminish as evaporative cooling lowers the vapor pressure of the remaining spill.

\section{H.16 HANDLING ACCIDENT SPILL THAT IGNITES FLAMMABLE LIQUIDS, THEREBY BREACHING NEARBY DRUMS WITH CADMIUM-CONTAINING COMPOUNDS (CD SALTS OR NICAD BATTERIES)}

This scenario uses the motif of an accidental spill escalating to a fire with subsequent involvement of nearby stored materials. In this case, the stored materials are posited to be used Nicad batteries. It is assumed that the heat of the fire is sufficient to cause fumes of $\mathrm{Cd}$ metal to escape (cadmium melts and boils at the relatively low temperatures of $321^{\circ} \mathrm{C}\left[609^{\circ} \mathrm{F}\right]$ and $\left.765^{\circ} \mathrm{C}\left(1,409^{\circ} \mathrm{F}\right]\right)$.

The rate of release of the cadmium (Cd) would be rapid upon rupture of individual sealed batteries by the heat of the fire.

$$
\begin{gathered}
\mathrm{Cd}(s) \rightarrow \mathrm{Cd}(g) \quad \Delta \mathrm{H}^{\circ}=+112 \mathrm{~kJ} / \mathrm{mol} \\
\Delta \mathrm{H}^{\circ}=+1.0 \mathrm{~kJ} / \mathrm{g} \mathrm{Cd} .
\end{gathered}
$$

Both Cd vapor and Cd-containing particulate matter would be formed.

\section{H.17 HANDLING ACCIDENT SPILL THAT IGNITES FLAMMABLE LIQUID; THE FIRE BREACHES NEARBY DRUMS CONTAINING DICHROMATE SALTS}

This scenario is the same as the previous one, but now a release of the carcinogenic salts of chromium ensues from the spill and fire. A typical fire would be the combustion of acetone.

$$
\mathrm{C}_{3} \mathrm{H}_{6} \mathrm{O}(l)+4 \mathrm{O}_{2}(g) \rightarrow 3 \mathrm{CO}_{2}(g)+3 \mathrm{H}_{2} \mathrm{O}(g)
$$

Once a drum containing the dichromate salts is breached, such a compound could become involved as oxidizers. For example,

$$
\mathrm{C}_{3} \mathrm{H}_{6} \mathrm{O}+8 / 3 \mathrm{~K}_{2} \mathrm{Cr}_{2} \mathrm{O}_{7} \rightarrow 3 \mathrm{CO}_{2}+3 \mathrm{H}_{2} \mathrm{O}+8 / 3 \mathrm{~K}_{2} \mathrm{O}+8 / 3 \mathrm{Cr}_{2} \mathrm{O}_{3}
$$

Both the unreacted dichromate salt (e.g., $\mathrm{K}_{2} \mathrm{Cr}_{2} \mathrm{O}_{7}$ in Equation $\mathrm{H} .29$ ) and the chromium (III) oxide $\left(\mathrm{Cr}_{2} \mathrm{O}_{3}\right.$ in Equation $\left.\mathrm{H} .29\right)$ would be dispersed by the fire as particulates. The rate of release of the dusts would be rapid, assuming full involvement in the fire. The mass of the dispersed dusts is taken to equal the mass of the dichromate waste (although, in fact, the preceding reaction would reduce that mass slightly). 